\title{
Gero Bauer
}

\section{HOUSES, SECRETS, AND THE CLOSET}

Locating Masculinities

from the Gothic Novel

to Henry James 
Gero Bauer

Houses, Secrets, and the Closet 
Gero Bauer is a research fellow at the Center for Gender and Diversity Research, University of Tübingen. His academic interests include gender and queer studies, and European literary and cultural history. 
Gero BAuer

\section{Houses, Secrets, and the Closet}

Locating Masculinities from the Gothic Novel to Henry James

[transcript $]$ 
An electronic version of this book is freely available, thanks to the support of libraries working with Knowledge Unlatched. KU is a collaborative initiative designed to make high quality books Open Access for the public good. The Open Access ISBN for this book is 978-3-8394-3468-0.

More information about the initiative and links to the Open Access version can be found at www.knowledgeunlatched.org.

\section{(1) $(1) \Theta \Theta$}

This work is licensed under the Creative Commons Attribution-NonCommercial-NoDerivs 4.0 (BY-NC-ND) which means that the text may be used for noncommercial purposes, provided credit is given to the author. For details go to http://creativecommons.org/licenses/by-nc-nd/4.o/.

To create an adaptation, translation, or derivative of the original work and for commercial use, further permission is required and can be obtained by contacting rights@transcript-verlag.de

\section{(C) 2016 transcript Verlag, Bielefeld}

\section{Bibliographic information published by the Deutsche Nationalbibliothek}

The Deutsche Nationalbibliothek lists this publication in the Deutsche Nationalbibliografie; detailed bibliographic data are available in the Internet at http://dnb.d-nb.de

Cover layout: Kordula Röckenhaus, Bielefeld

Cover illustration: zach / photocase.com

Printed by Majuskel Medienproduktion $\mathrm{GmbH}$, Wetzlar

Print-ISBN 978-3-8376-3468-6

PDF-ISBN 978-3-8394-3468-0 


\section{Contents}

Preface 17

Introduction | 9

Prelude: Bluebeard | 9

Context: History, Houses, and Masculinities | 13

Methods: Secrecy, Sexuality, and Liminal Spaces | 28

Bluebeard's 'Closet:' Gothic Novels | 45

Phallic Power:

Horace Walpole's The Castle of Otranto | 45

The Power of Absolute Spatial Access:

Ann Radcliffe's The Mysteries of Udolpho | 58

A 'Male Heroine:'

William Godwin's Caleb Williams $\mid 78$

The Contested Secret Room: Sensation Novels | 101

Powerless Landlords:

Wilkie Collins' The Woman in White | 101

Performing Subversion:

Wilkie Collins' No Name | 122

A Female Bluebeard:

Mary Elizabeth Braddon's Lady Audley's Secret | 143

Globalising the 'Closet:' Henry James | 165

Masculine Disempowerment in a Woman's Mansion:

Henry James' “The Aspern Papers” | 165

Female Power in the Cage of Knowledge:

Henry James' "In the Cage" | 180

Autoerotic Paranoia in the 'Closet:'

Henry James' “The Jolly Corner” | 199 
Coda 213

Works Cited | 223

Primary Literature $\mid 223$

Secondary Literature | 223 


\section{Preface}

This book is the revised version of my doctoral dissertation, which was accepted at the Faculty of Philosophy, Eberhard Karls Universität Tübingen in 2014.

I am immensly grateful to my supervisors, who helped me shape my ideas into what is now this book. Prof Ingrid Hotz-Davies at the University of Tübingen for humour, patience, and for the ability to always engage with even my most outrageous close readings. The idea for this project emerged from one of her seminars. Prof Mark Turner at King's College London for his enthusiasm, critical mind, and for supervising my work against all odds of university administration. Both were part of an ongoing and immensly fruitful conversation that gave me exactly the kind of environment I needed to push my work forward.

I also thank the German National Academic Foundation (Studienstiftung des deutschen Volkes), who not only funded my doctoral studies, but also provided me with invaluable opportunities and networks, and some of the most defining experiences during my time at university.

I am grateful to the English Faculty at the University of Cambridge for hosting me and my work for a while.

I would also like to thank the Center for Gender and Diversity Research (ZGD) at the University of Tübingen for funding the publication of this book.

Life in academia depends as much on intellectual exchange as on emotional support from within and without. Over the past five years, I got to spend time with some of the most loving and caring people I can imagine, whose contribution to the success of my work was beyond measure. All my friends who shared their theatrical, musical, and literary talent and enthusiasm with me - thank you. Very special and warm thanks goes to Rebecca Hahn and Jutta Kling, both colleagues and friends, and partners in crime.

My mother and father both in their own way made this project possible. Their continual support and never-failing trust in my academic abilities were always a source of comfort. I dedicate this book to them. 



\section{Introduction}

\section{Prelude: Bluebeard}

Once upon a time, there was a powerful count, who lived in a big castle. Nobody knew much about him, and everybody was afraid of him because of his blue beard. One day, the count went into the nearby village, and asked a young woman to marry him. She became his wife, and went to live with him. The count was kind and generous, albeit mysteriously secretive about his affairs. He allowed his wife to freely explore every part of her new home, and enter every room, except one, the key to which he always kept to himself. One day, the count had to go away for a few days. He trusted his wife with all the keys to all the rooms in the castle, but told her that, under no circumstances, must she use the little golden key to open the forbidden chamber. When the count was gone, curiosity overwhelmed the young woman, and she opened the count's secret room. In it, she found the corpses of several women, hanging from the ceiling, and the floor was covered in their blood. Shocked and frightened, the count's wife dropped the key in the pool of blood. The key was enchanted, and the young woman, try as she might, could not clean it from its stain. When the count returned, he demanded the key back from his wife. When he saw the blood, he knew what she had done. The cruel man revealed to her that every woman who entered the forbidden chamber despite his warnings would have to die, and her body would be locked away in that very room. The count dragged the crying woman to the room to kill her, but she asked him to spare her for one more day, so she could say her prayers, and die in peace. He agreed, and the resourceful young woman managed to ask her sister to get help. When the day of prayer was nearly over, the wife's brothers knocked down the castle's doors, killed the count, and rescued their sister. Bluebeard's spell was broken, and no more women would have to die at his hand.

Charles Perrault's "La Barbe bleu," the first written version of the story of Count Bluebeard - the Bluebeard 'ur-text,' so to speak - was published in Paris in 1697 in a collection of fairy-tales entitled Les Contes de ma mère l'Oye (Perrault 1697). Based on an oral tradition of popular fairy-tales, Perrault's story has since 
been retold countless times, and became a European - and, later, international - phenomenon. Although the tale's adaptations and appropriations vary considerably, some particular elements are always the same: Bluebeard's dark secret, the threat to the woman's safety, and the secret's ultimate disclosure. Emil Heckmann, in his impressive 1930 study on the literary history of the Bluebeard tradition, traces versions of the tale from central Europe to Africa, Turkey, and Palestine (cf. Heckmann 1930). Heckmann distinguishes between three 'types' of the Bluebeard story: the mythological variants, the main variants, and the Perrault variants (cf. Heckmann 1930: 19-20). This distinction is instructive, because it shows that the Bluebeard theme has not only been retold in the form of other fairy-tales - most prominently, maybe, in the Brothers Grimm's tales "Fitcher's Bird" ("Fitchers Vogel"), "The Castle Murder" ("Das Mordschloss"), and "The Robber Bridegroom" ("Der Räuberbräutigam"), all published in the Kinder- und Hausmärchen - but also, more or less obviously, in later prose, such as Charles Dickens' "Captain Murderer" (1860), or Angela Carter's “The Bloody Chamber” (1979). The elements of the Bluebeard tale also feature prominently in the Gothic tradition, with its array of male characters who hide a dark secret in their castles and houses, a secret which is always in danger of being found out. As Maria Tatar observes, the conventions of the Gothic "are the very plot elements basic to the Bluebeard story. Both Gothic novels and Bluebeard tales chart the vagaries of a whirlwind romance with a stranger or an impulsive marriage to an outsider - to a man whose house contains a room in which is buried a grim secret[...] about his past." (Tatar 2004: 68)

The dynamics of secrecy negotiated in the Bluebeard tradition establish a pattern that features markedly in late eighteenth and nineteenth century literature, and which, I will argue, becomes a hallmark of modern constructions of masculinities. Bluebeard's secret both empowers him, and makes him paranoid: keeping knowledge from his wife, and denying her spatial access to it, Bluebeard establishes an epistemological imbalance to his advantage. At the same time, however, he creates a secret for himself, which he is anxious to protect. Any woman who tries to penetrate the secret chamber - and undermine the basis of his gendered superiority - must die. She is silenced, erased, as it were, from an epistemological economy, and becomes herself part of the secret, in that her body is locked away in the very room she dared to enter. Bluebeard, then, in his effort to protect his power and advantage, creates a bloody reminder of his own deficiency, which he must, at all cost, keep hidden. Even more conspicuously, however, Bluebeard seems willing, even compulsorily, to make knowledge of his secret public: not only does he tell his wife that there is a room that she must not enter, but, in giving her the key, he actually provides her with the physical means to disclose his secret, only to per- 
petuate his manic need to silence a femininity to which he precariously constructs himself as superior.

The place of femininity itself is further complicated by the frequent presence of a 'female helper' in many versions of the story. In the Grimm's Bluebeard variants, the young heroine meets an old woman who assists the castle's master in his dark deeds, a fact which demonstrates "the many ways in which Bluebeard makes use of women, as a sexual object and as a reliable accomplice in his crimes" (Hempen 1997: 48). The role of 'female helper' provides an alternative to the victimised femininity of women in the Gothic tradition, but remains morally ambiguous. While it is true that "Bluebeard's need of a female helper, of a woman who does his dirty work and thereby necessarily shares his secrets, may ultimately contribute to his downfall" (Hempen 1997: 48), the old woman is nevertheless actively complicit in his crimes, and, hence, protects the very patriarchal structures that endanger herself and other women in the first place. The 'female helper,' it appears, can choose whether to take homosocial advantage of her privileged situation - and help the young woman - or not. Rose Lovell-Smith rightly foregrounds " $t$ t]he female bonding [between heroine and 'female helper'] within the husband's house [...] to be a dangerously subversive element" (Lovell-Smith 2002: 199).

Perrault's "La Barbe bleu," then, stages a masculinity which, because it so heavily relies on a politics of secrecy for the promotion of patriarchal advantage, lives in a state of constant denial and fear of discovery. Perrault diagnoses paranoia at the very centre of patriarchal authority. Bluebeard's castle, as so many houses in the Gothic, is "an architectural embodiment of its owner's mind" (Tatar 2004: 53). As such, we find in the Bluebeard tradition the roots of what, in the course of the nineteenth century, will turn into the 'sexualised' rhetoric of the 'closet,' the secret whose meaning cannot be named, but has to be spoken about excessively. Just as the late nineteenth century 'open secret' of homosexuality denies what it is, but says that it is there, Bluebeard cannot name the contents of his 'closet,' indeed fears it, but must speak about it, and, hence, repeatedly risks its disclosure.

Power based on secrecy is prone to trigger paranoia. While the 'speech act' of secrecy affords the person who utters it the advantage of power over knowledge ('You do not know what I know'), the language of secrecy will always invite interpretations the secret holder cannot control. "[S]ecrets secure domination yet also come back to haunt those who possess them." (Tatar 2004: 80) Bluebeard's paranoia, then, is twofold: he can neither reveal the secret his power is based on, nor control or contain his wife's curiosity and thirst for knowledge. Shuli Barzilai rightly recognises this epistemological conflict as the central element of the Bluebeard myth, and calls it “'epistemophilia:' an epistemological thrust or drive, a desire to know" (Barzilai 2009: 5). Within a logic of patriarchal power - and especially in the context of emerging middle-class ideals of domesticity in the eight- 
eenth century - this feminine desire to know is deviant, and potentially subversive. The curious woman, a hallmark of the Gothic, questions male hegemony over knowledge and domestic space, and exposes secretive masculinity as inherently paranoid. Strikingly, the reader of the Bluebeard tale - and of Gothic narratives increasingly occupies the position of the curious wife, and becomes the 'paranoid reader' who needs to 'know' the secret. After all, "[w] hat arouses curiosity, [...] is both the character who has something to hide and the secret that he is harboring" (Tatar 2004: 48). What is important, in the end, is not so much the content of the secret. Bluebeard's secret is so powerful because it does not have to make its violence explicit. Ann Radcliffe's Emily wanders through Udolpho, waiting to open a door to a horrible sight she never actually finds. The Gothic male's secret is a rhetorical device whose content varies and changes in the course of the nineteenth century. Tatar quotes Edna St. Vincent Millay's 1917 “Untitled Bluebeard Sonnet:" "This door you might not open, and you did; [...] / But only what you see...Look yet again - / An empty room, cobwebbed and comfortless.” (St. Vincent Millay 2004)

The gendered, and increasingly 'sexualised' conflict I will be addressing throughout this book will revolve around this economy of knowledge. I will demonstrate how a male monopoly over knowledge, especially within the domestic setting already set up in Perrault's Bluebeard tale, will, in the course of the eighteenth and nineteenth centuries, get increasingly questioned in a literary discourse that problematises men's paranoid disposition in the face of both women's 'epistemophilia,' and the historically induced need to position themselves within a more and more rigid dichotomy of genders and 'sexualities.'

The desire to 'know,' to read ourselves and others, is an indispensible element of human identity formation and interaction. The immense and continuing cultural influence of the Bluebeard myth demonstrates "the importance in human life both of secrets, protected by all kinds of prohibitions and threats, and of irresistible curiosity - the powerful attraction exerted by the desire to know" (Gorilovics 2000: 26). I will explore how this tension, which has such a significant impact on our social being, is crucially shaped by historically contingent discourses that have an impact on the way we perceive ourselves and others. Secrecy, in literary discourse since the eighteenth century, has played a vital and conflicted role in shaping categories such as 'masculine'/'feminine,' and 'homosexual'/'heterosexual.' The close affinity of secrecy and masculinity in the character of Bluebeard make him, as Monika Szczepaniak remarks, a prototype of a problematic masculinity in constant crisis (cf. Szczepaniak 2005: 3). 


\section{Context: History, HOUSES, ANd MAsCulinities}

\section{Outside the 'Closet:' Pre-Modern Concepts of 'Sexuality' and 'Gender'}

The texts chosen to illustrate my argument cover, in their entirety, a period of almost one hundred and fifty years, from the publication of Horace Walpole's The Castle of Otranto in 1764 to Henry James' late tale "The Jolly Corner," first published in 1908. As such, the time span I will be looking at roughly corresponds to what historians call the 'long nineteenth century.' The term was coined by British historian Eric Hobsbawm in his three-volume history of Europe, referring to the time between the French Revolution in 1789 - the beginning of the end of the 'ancien régime' - and the start of the First World War in 1914, which marked the end of the balance of power prevalent in nineteenth century Europe (cf. Hobsbawm 1962; Hobsbawm 1975; Hobsbawm 1987).

Late eighteenth and nineteenth century European culture not only experienced a time of political upheaval, but also saw crucial changes and developments in discourses and practices concerning domestic privacy, genders, and 'sexualities.' In the course of about a hundred and fifty years, middle-class values of what we now perceive as 'naturally' feminine and masculine, homosexual and heterosexual, and the ways we think about the privacy in our homes were being established. Anxieties, concerns, and renegotiations regarding the newly emerging private sphere of middle-class domesticity, and the roles of men and women in- and outside this sphere found their particularly productive expression in the Gothic novel and related genres.

Historically speaking, the period in question - the long nineteenth century was particularly productive in terms of newly emerging forms of gendered and 'sexual' identities, and their manifold expressions in the domestic private sphere of the middle-class home. Since the publication of Michel Foucault's seminal first volume of his History of Sexuality in 1976, which dates the 'invention' of the modern notion of homosexuality as an identity category back to the end of the nineteenth century (cf. Foucault 2006), other historians have contributed to a by now well-established understanding of the historical contingency and specificity of cultural and linguistic framings of desire and identity. Alan Bray's study of English 'molly houses' provided an example of the emergence of a recognisable group of 'sexually' and/or gender-'deviant' people at the turn of the eighteenth century (cf. Bray 1995); and David Halperin's historical take on homosexuality made an important point in demonstrating that our modern notions of 'sexualities' are simultaneously historically dependent on, and crucially different from earlier terms and practices, such as effeminacy, pederasty, friendship, and inversion (cf. Halperin 2002). Both 
authors show that the idea of a 'sexual identity,' which could be theorised, applied to a certain group of people, or used by a person to define themselves, is a phenomenon that has to be dated back at least to the two centuries between 1600 and 1800 . Although recently, scholarship in queer studies has focussed more on contemporary social and cultural issues (cf. e.g. the works of Lee Edelman, Jack Halberstam, and José Muñoz), these fundamental works of historical inquiry are still a valuable starting point for any investigation of genders and sexualities in the recent past. With the appearance of 'sexual identities' in the modern sense, as opposed to, for example, the vague and highly problematic earlier concept of sodomy (cf. e.g. Bredbeck 1991; Goldberg 1992; Hammond 2002), sexuality emerged, especially for men, as one of the main axes of identification. It became vital for every single person to define themselves and others in terms of their 'sexual' selves. Sexuality as the secret, the discursively produced regime over bodies, which reached its peak around the turn of the twentieth century, will be the historical terminus of this study. I will be tracing the influence of ever more specific 'sexual' discourses in fictional negotiations of masculinities and male desire in the context of a rhetoric of secrecy which, over the course of a hundred and fifty years, can be read more and more easily in 'sexual' terms. During this time, European society witnessed a change in attitudes towards privacy, the individual, and also - and tightly linked to these two - the relationship between men in the persisting ambivalence of homosocialty and homosexuality. The shifts in the discourses on, and practices of same-sex desire affected the system of gender definitions and the self-fashioning of a modern masculinity that constantly defined itself - and still defines itself - in opposition to, and dependent on the powerful secret of homosexuality.

The blackmailability of western masculinities was, however, due not only to an increasingly rigorous 'sexual' binarism, but also to a simultaneously emerging dichotomy of genders. As post-structuralist theorists, including Judith Butler (cf. Butler 2006) and Judith Halberstam (cf. Halberstam 1998), have abundantly argued, 'gender,' just as 'sexuality,' is culturally produced. It is connected to, but not necessarily inseparable from biological sex. The biological 'facts' - if they are 'facts' at all - behind our current binary system of sex and gender begin to lose importance as markers of difference once we realise that 'masculinity' and 'femininity' are actually - to some considerable degree at least - 'performed' by bodies. Considering the history of western civilisation, the primacy of biological 'sex' over socially constructed 'gender' is itself not as stable and unchanging as we tend to believe. Recent scholarship has even begun to question the validity of biological sex and a male-female binarism as a valid system of reference altogether (cf. Voß 2010).

Introducing this train of thought, Thomas Lacqueur, in his seminal 1990 study Making Sex, showed that, historically, biological sex has not always determined a 
person's gender, but that, on the contrary, "sex, as much as gender, is made" (Laqueur 1990: ix). Before the eighteenth century, Lacqueur argues, the male body and the female body were not perceived as being two biologically different organisms. Instead, the female body was understood as a lesser version of the male body. It was "a world where at least two genders correspond[ed] to but one sex, where the boundaries between male and female [were] of degree and not of kind, and where the reproductive organs [were] but one sign among many of the body's place in a cosmic and cultural order that transcends biology" (Laqueur 1990: 25).

Lacqueur calls this continuum of bodies a "one-sex model" (Laqueur 1990: viii). This model, however, in the course of the seventeenth and eighteenth centuries, was gradually - albeit never completely - replaced by a "two-sex model" (Laqueur 1990: viii), the understanding of the male and female body as crucially and unchangeably different from each other. Sex itself came into focus as a distinguishable notion: "The tacit category 'sex' became unprecedentedly explicit in this period." (McKeon 2005: 271) Male and female reproductive organs began to be given separate names (cf. Laqueur 1990: 149). The biological 'facts' ('sex'), since then, have been believed to determine a person's gender, and, hence, their political and economic role. "Biology - the stable, ahistorical, sexed body - is understood to be the epistemic foundation for prescriptive claims about the social order." (Laqueur 1990: 6; cf. McKeon 2005: 271) The advent of the modern public-private dichotomy brought with it a debate about why women should not be part of the public sphere, and this debate was more and more fought in biological terms. Men "generated evidence for women's physical and mental unsuitability for [the public]: their bodies unfit them for the chimerical spaces that the revolution had inadvertently opened" (Laqueur 1990: 194).

What did it mean, then, for 'masculinity' to be now more or less inseparably and unchangingly tied to a 'male' body? The justification of the system of patriarchy, which, until the Renaissance, had depended on transcendental truths that manifested themselves in a hierarchy of gender difference, shifted to a biological reasoning. Power relations had to be newly negotiated in a system in which the relationship of men to women was not "one of equality or inequality but rather of difference" (Laqueur 1990: 207). While, in a continuum of sex and gender relations, men used to measure their 'manliness' according to their virility and physical power over other men and women - whether 'sexually' or not - the modern dichotomy of sexes, combined with the emergence of the 'homosexual'/'heterosexual' polarity, created a society in which "masculinity came to be consistent only with an anatomically gender-based differential and definable by sexual behavior" (McKeon 2005: 274). In the course of this study, I will be exploring how modern masculinities have had to incessantly re-affirm the fiction of both their 'natural' 
gender identity, and their alleged heteronormativity against the cultural mirrors of both women and 'deviant sexualities.'

\section{The Emergence of Modern Domestic Privacy}

In order to better understand how secrecy became an integral part of modern discursive productions of gendered power structures, and their expression in fictional architectures of the home, and how discourses of 'sexual identities' began to heavily influence modern masculine self-conceptions, we should first have a look at how, in the course of the seventeenth and eighteenth centuries, a modern notion of domestic privacy, crucially dependent on the emergence of the new European middle classes, first came into being.

What is 'privacy'? The word itself is a relatively recent addition to the English language. 'Private' and 'privacy' hardly occur in medieval texts, and although the related words 'privy' and 'privity' have a similar meaning as their later variants, it is significant that, from the seventeenth century onwards, we witness an immense increase in usage of 'private' and 'privacy' (cf. OED 2007). This late linguistic occurrence of 'privacy' suggests a change of mentality: "During the Renaissance privacy was emerging as a category of experience in its own right." (Huebert 1997: 29) From its earliest usage, privacy has always been closely linked to discourses of secrecy. Things could be concealed 'in private,' both in a literal and a figurative sense, and a 'privacy' could also refer to a secret itself (cf. Huebert 1997: 31-32). Early modern texts also use 'privacy' in connection with interiority, in the sense of keeping things to oneself. This interior space, which only gradually became of interest to writers of the period, had not always been regarded as desirable: "There is a progression from suspicion of privacy in the earlier texts to acceptance of and even a cherishing of privacy in the later ones." (Huebert 1997: 35)

Shaun MacNeill provides the most narrow and precise definition of privacy in its current usage: "Privacy is the condition which obtains to the degree that new information about one's self is not acquired by others." (MacNeill 1998: 438) Privacy, then, is a condition in which a person finds themselves, whether by intention or not, when no other person acquires previously unknown information about them. This very basic definition is useful to see how closely issues of privacy are linked to secrecy. New information that is acquired by somebody about somebody else can, but does not necessarily have to be, a secret.

In European societies since the eighteenth century, and with the growing importance of individual rights, privacy has not only been regarded as desirable, but it is even deemed to be psychologically necessary: "Privacy is important because it is posited to provide experiences that support normal psychological functioning, 
stable interpersonal relationships, and personal development." (Margulis 2003: 246) For our purpose, this becomes especially important in the context of the male homosexual 'closet': personal information about somebody's 'sexuality' - in its modern form - is regarded to be private information and, hence, subject to one's own knowledge management. However - as with many other stigmatised forms of information - knowledge about a person's 'deviant' sexuality is such that the person often feels under pressure not to disclose the information freely, thereby making it a secret. "Losses of privacy have the potential for life-and-death costs when a person has as a critical goal the concealment of his or her intentions [...] or identity." (Margulis 2003: 248)

Why, though, did modern forms of individual privacy only develop a few centuries ago? As Jürgen Habermas demonstrates, the end of absolutism, the abolishment of the feudal system, and the emergence of a modern civil society in the eighteenth century brought with it the formation of a 'private,' bourgeois sphere, a "bürgerliche Gesellschaft" (Habermas 1990: 67), that self-confidently set itself against the 'public' state apparatus (cf. Habermas 1990: 63-67; McKeon 2005: xixxx; Ariès 1989: 8). Society had grown larger, new methods of communication had made the world less immediately accessible, new spatial arrangements made it possible for greater parts of the population to consciously seek 'privacy' (cf. Ariès 1989: 1-2). Two spheres had emerged that were associated with two distinct types of behaviour: "that which was permissible in public [...], and that which had to be hidden from view" (Chartier 1989b: 16).

How, then, did these big-scale social and political changes affect the life of the individual person? According to Michael McKeon, in an age in which knowledge, especially concerning the running of the state and society, was more and more a matter of open debate, "making tacit knowledge explicit" (McKeon 2005: 5), not only was the power of the absolutist state apparatus increasingly questioned, but, "over the long term, the indefinite transferability of royal absolutism fed the notion that even, perhaps only, the individual was endowed with an absolute authority" (McKeon 2005: 6). McKeon calls this social phenomenon "the devolution of absolutism" (McKeon 2005: 3), a process that, over the centuries, trickled down to the realm of the domestic. Patriarchal ideology drew "an analogy between the state and the family that legitimated each institution by associating it with the "naturalness' of the other" (McKeon 2005: 11). The male head of the household claimed the now mobile absolutist ideology for himself, recreating its power structures on a small scale within a new private sphere of individual domesticity, legitimised by a claim to individual autonomy and power. The individual increasingly claimed their rights to 'private' property, personal economic interests, and liberty from external interference, "a freedom from state control whose corollary was the autonomous agency of the individual subject" (McKeon 2005: 21). Protestantism, at the same 
time, made religion a matter of conscious and explicit discourse by questioning the tacit authority of the 'old' church, delegitimising any absolute religious authority, and making religion a matter of 'private' and individual responsibility and interiority (cf. McKeon 2005: 33-39).

This development reached further and further down into the deepest recesses of private existence, in a continual process of relocating authority, shifting focus more and more to the individual, and their domestic and interior existence. It found one of its most striking expressions in the spatiality of the Protestant devotional closet, the most private and intimate personal space within the home, where the most carefully guarded secrets of the soul were shared with God, and nobody else: "The interiority of conscientious experience and experiment was correlated with the interiority of the domestic spaces in which these activities occurred, a correlation between micro- and macro-, bodily and architectural privacy." (McKeon 2005: 43)

As Roger Chartier rightly observes, "[t]he history of private life[...] is not a national phenomenon. Its natural setting is that of an entire civilization, the Western world." (Chartier 1989a: 609) England, however, played an especially significant role in the development of a modern, bourgeois private sphere. Christoph Heyl points out that in England - and in London in particular - a unique combination of prerequisites facilitated the development of modern privacy in a way that was different from other European countries (cf. Heyl 2004: 12), and made it the 'birthplace of privacy.'

In the modern process of privatisation described so far, the family and the home became focal points of the new private sphere. The public-private dichotomy, however, was also reproduced within this space: "The modern 'home', the thoroughly privatized replacement of the traditional household [...] reproduced a divided domain within its own walls." (McKeon 2005: 111) This division was also gendered, recreating "the subordination of private to public authority in the unequal relationship of husband and father to wife and children" (McKeon 2005: 111). Privacy is as much lived in an actual space as it is rhetorically constructed. A room within a house is 'private' to the degree to which it can be situated on two axes: its actual spatial seclusion, and the social convention that designates it as the private space of any given person (cf. Peters 1998). Privacy within the home, hence, depends as much on social norms - such as gender roles - as on a new spatial organisation of houses.

Architectural criticism and theory since the end of the twentieth century has seen a theoretical shift towards a more interdisciplinary approach to houses, housing, and home making, and has increasingly asked "how ideas and assumptions about social relations around gender, class, and 'race' get translated into domestic space, embodied in the home, and represented in its spatiality" (Walker 2002: 823). 
Research on the meaning of household structures for the men and - especially - women living in them, "investigations of spatial experience, memory, and the sense of place, and of the roles of power, difference, and design in shaping these experiences" (Friedman 1999: 407), have opened essentially new perspectives on the way houses have shaped the lives of people, and vice versa (cf. Kwolek-Folland 1995: 3-8).

The basic assumption of most of these theories is that relevant ideas about social behaviour, the relations between people - especially between men and women - and certain normative assumptions about gender roles get translated into the way a house is structured and ordered. Alice Friedman suggests that houses, from the early modern period onwards, tended to represent architecturally what the owner wanted the world to see of his own supposed character traits: "The houses were in truth but the outward signs of what the inhabitants hoped would be an inward grace. They wished to transform themselves along with their environments." (Friedman 1999: 409) Similarly, the Victorian home had heavily masculine connotations, in its representative function, and in terms of property, territory, and patriarchal control (cf. Walker 2002: 826).

Lynne Walker demonstrates how, in the nineteenth century, due to Victorian assumptions about the public and the private - and, more particularly, the association of women with the private and the home as a limited sphere, and men with the public - and the doctrine of 'separate spheres,' certain spaces, even certain rooms within the house, came to be gendered feminine, and others masculine (cf. Walker 2002: 824-826). A new patriarchal domestic ideology emerged which both assigned moral authority to women, and restricted this kind of moral superiority to the home: "One function of domestic ideology [was] to reconcile the increasingly common argument for the ethical superiority of women with the persistence, perhaps even aggravation, of their socioeconomic subordination." (McKeon 2005: 169)

People of higher social strata came "to value female idleness, in the strict sense of eschewing all modes of production for the market, [...and] female accomplishments, while cheap labor did much of what had once been the inside work of wives" (McKeon 2005: 177). At the same time, the role of the female as "the angel in the house' was given new value as a moral and ethical authority. She was thought to have a beneficial influence on husband and children, and watched over the household's economy and management (cf. McKeon 2005: 181).

Privacy within a household became more and more complex, depending on who was trying to achieve privacy from whom:

"The family sought privacy from domestic servants; males and females increasingly were thought to require segregation from each other; children had to 
be separable, if not entirely segregated from each other; personal privacy was required for reading, writing, contemplation, and bodily evacuation; and all members of the household sought privacy from the outside world of uninvited visitors." (McKeon 2005: 238; cf. Heyl 2004: 263)

Within the house, space was not equally accessible to all members of the household. Most importantly, the house's hall, since it was the public centre of the house, was a specifically masculine space. Here, the master of the house received visitors, and could display his power in front of other men. Women, although not completely excluded from this public space, were mostly restricted to the upper, more private parts of the house. Traditionally 'feminine' rooms are the kitchen, the nursery, the dairy, and the laundry. However, since upper-class - and, increasingly, middle-class - women got used to having more and more servants, even this female kind of influence over the household economy - namely taking care of the children, the food and the laundry - got taken away from them, which left them with the only part of the house where they could have some kind of space of their own: the bedroom (cf. Friedman 1992: 44-45; Heyl 2004: 288-297; Walker 2002: 824). Even the bedroom, however, was an almost exclusively female space only for younger, unmarried women or widows. Married women shared their bedrooms with their husbands, and were often restricted to a small table as the only private space left to them for all-female homosocial contemplation and correspondence (cf. Kross 1999: 396-401). What remained for them was the privacy of the soul: "At this lowly rung of the hierarchy the devolution of absolutism becomes instrumental in disclosing interior realms of autonomy and privacy, the secret precincts of the self [..., an] autonomous privacy [...] for women in general in a man's world, utterly deprived as they are of direct access to the public realm." (McKeon 2005: 148)

Even though the processes of architectural innovation, meeting the needs of a new desire for privacy, was first and foremost a phenomenon of upper- and middle-class homes, the lower orders increasingly copied the innovations of their social betters since "the impulse toward physical privacy was experienced as a universal human value rather than as proper to the socially elevated alone. What had begun as an elite withdrawal from collective presence had become the architectural expression of an emergent individualist norm." (McKeon 2005: 252)

This growing need for domestic privacy found its most striking (and culturally influential) expression, in both upper- and middle-class homes, in the closet. The closet, in the course of the sixteenth and seventeenth centuries, developed as a small, but important room where books or rarities were kept, and which could serve as a place of devotion or private reading for male and female members of a household, "a comparatively small space that enclosed yet smaller ones, and its contents could be quite diverse" (McKeon 2005: 225). Over the next centuries, the 
closet became the most private space of the house, where the person having access to it kept their secrets. Both men and women might have a closet, female member of a household, however, less so, and they often varied considerably in content and relevance for private and public purposes: "If a husband's closet were furnished with resources needed to master the world (books, maps, and scientific instruments), his wife's would be likely to contain materials of household management (baskets, bottles, and cooking utensils)." (Huebert 2001: 41) Women - at least in general - were not expected to use a space like the closet for properly individual, 'private' activities - like writing or serious studying - that went beyond the fairly publicly scripted activity of 'private' praying. A woman's privacy was usually only a conditional state that could constantly be interrupted by men (cf. Huebert 2001: 58-63).

The association of the - mainly male - closet with the keeping of secrets, which I will discuss further below, can already be observed in the seventeenth century royal household, where the king's cabinet or closet was the meeting place of councils that discussed the most delicate state affairs, and in which the king's most private secrets were kept, guarded by his secretaries, their title's etymology suggesting their function as keepers of secrets and guardians of their master's keys (cf. McKeon 2005: 228-230). That the relationship between a male master and his secretary was potentially precarious, both because of the danger of disclosure, and because of the close homosocial relationship between two men of different social ranks, will become important later for the readings of literary 'closets' as spaces of homosocial intimacy and secret sharing:

"The liability of the secretary has a sexual as well as a social dimension. In the homosocial intimacy of seventeenth-century male friendship at this level of social interaction there is an erotic component that parallels the amatory energy with which the emergent model of marriage for love challenges the traditional model of the dynastic marriage of alliance, a parallel that contemporary discourse is increasingly inclined to test as a competition." (McKeon 2005: 232)

The increasing need for privacy in the seventeenth and eighteenth centuries not only found its expression in architectural changes allowing for more and more actual private space within the home, but also led to the emergence of new literary forms that focussed on the individual, and the innermost private recesses of the mind. A new consciousness of the individual, and their need for privacy is closely linked to the experience of textual production and consumption: "The emergence of the concept of privacy as a personal right, as the very core of individuality, is connected in a complex fashion with the history of reading." (Jagodzinski 1999: 1) 
The most important and influential new literary form was the novel. Its subject matter were 'low,' common themes, and thoughts about the private lives of individuals (cf. Heyl 2004: 475). This was certainly a novelty: "Private activities and intimate feelings (to which the public has no access) were not a subject of writing before the second half of the seventeenth century." (Foisil 1989: 361) Until the sixteenth century, a lot of literature was "characterized by a dissimulation of private and intimate subjects" (Goulemot 1989: 370). Matters of individual private experience were simply of no interest.

Works of fiction began to experiment with narratives that invade their characters' most private spaces, and expose their secrets. The novel, from the beginning, was a genre interested in matters of privacy and its boundaries (cf. Heyl 2004: 476). People began to think of someone's 'private self' as their rightful space to keep secrets, a necessary refuge from the outside, and the social world around them, a space of reflection about the individual 'I': "Secrecy and concealment [were] no longer treasonable but the prerogatives of private life. The mistrust of solitude and aloneness ha[d] been transformed into the valuing of private, physical, psychological space.” (Jagodzinski 1999: 6)

Ian Watt, in his influential study on The Rise of the Novel, shows that characters in novels were no longer - like in earlier forms of fiction - just allegories or types, but individuals that acted in a contemporary environment, a fact that appealed to a new middle-class readership conscious of, and interested in the exploration of the private, individual self (cf. Heyl 2004: 518). Watt was the first to realise the intimate connection between the emergence of the novel and new forms of 'private' architectures. In Samuel Richardson's novels, he sees a tendency "towards the delineation of the domestic life and the private experience of the characters who belong to it: the two go together - we get inside their minds as well as inside their houses" (Watt 1995: 175). J. Paul Hunter makes the link between the novel and the private sphere even more explicit:

“The novel's willingness - indeed, incessant need - to invade traditional areas of privacy (the bedroom, the bathroom, the private closet) and explore matters traditionally considered too personal to be shared leads to an entirely new understanding of the relationship between public and private. [...] In the novel, readers can peek into traditionally secret spaces - physical, mental, or emotional[.]" (Hunter 1990: 37-38)

As Christoph Heyl rightly points out, however, these private spaces were by no means 'traditional.' They became the subject matter of the novel only around the same time as they actually became real for a wider part of the population. These new private spaces were the new phenomenon, and the novel, as a genre, reacted 
to this development (cf. Heyl 2004: 522). It is no coincidence, then, that the rise of the novel, and an increase in private reading in general coincided with the creation of more and more private domestic spaces:

"As reading became less a communal activity, it also became associated with the private spaces being created in seventeenth-century homes. [...] It was easy to make the link between the 'discovery' power of print and the private rooms or storage places known as cabinets. The metaphor was a simple one: either could contain treasure (words or jewels) or hide secret corruption." (Jagodzinski 1999: 12; 16)

Kathy Mezei and Chiara Briganti similarly argue that the new great houses of the bourgeoisie and the novel have their roots in the same structural changes in seventeenth- and eighteenth-century society. Famous authors of the period, like Jane Austen, Elisabeth Gaskell, or George Eliot, chose subject matters that were often domestic, the private life and the concept of home. "The comparatively recent notion of privacy resonates in this new literary form that explores intimate, private scenes of the mind and society often set within a middle-class household and home." (Mezei/Briganti 2002: 838) The novel, like the house, is "a dwelling place - a spatial construct - that invites the exploration and expression of private and intimate relations and thoughts" (Mezei/Briganti 2002: 839).

The novel was the first genre that was explicitly concerned with issues of privacy and - following from that - secrecy. Being a genre that expresses concerns about the private on various different levels - spatially and psychologically - the link becomes obvious: the creation of more and more private spaces - in real life and in the novel - led to an increasing interest in what others kept private. Privacy creates secrecy:

"While one could rely on the safety of one's own home, those of one's nextdoor neighbours became unknown quantities. The perfectly ordinary became unfathomable and thus potentially mysterious and interesting. It was only in the realm of the imagination that unopposed and immediate access to such houses could still be possible. [...T] he preoccupation with protecting one's own private sphere almost instantly engendered a fascination with other people's private lives." (Heyl 2004: 561)

The Gothic and its traditions are the most prominent literary expressions of these developments. Although inherently 'aristocratic' in its depiction of castles and the gentry, the Gothic novel reflected many of the concerns of its predominantly middle-class readership, and heavily influenced more 'domesticated' fiction of 
contemporary and later writers. I will show how, in literary discourse from the mid-eighteenth century to the beginning of the twentieth century, and in the context of ever more prominent discourses of gendered and 'sexual' binarisms, the closet increasingly becomes the metaphorical 'closet.'

\section{Choice of Texts}

We can analyse Gothic fiction, for the sake of defining the genre, according to certain elements and conventions that characterise a work as 'Gothic.' Eighteenth century Gothic, and that part of the tradition that would closely follow along its lines, is usually set "in an antiquated or seemingly antiquated space" (Hogle 2002: 2), mostly an old castle, a monastery, a building that has a history. This edifice then always serves as the stage on which the (mostly gendered, as we will see) conflict unfolds. Crucially for our purpose, the Gothic castle is always, unfailingly, a Bluebeard's castle: "Within this space, or a combination of such spaces, are hidden some secrets from the past [...] that haunt the characters, psychologically, physically, or otherwise." (Hogle 2002: 2) More specifically, it is usually the male villain and master of the castle who is haunted by the secret, which he keeps carefully hidden in a secret room, a secret trunk, a secret cupboard, or his closet. The house comes to stand for the mind, its hidden rooms are the secret recesses of its owner's thoughts and emotions: "[T] he locus of the truly mysterious unknown becomes the human mind rather than the haunted house." (Anolik 2007: 2) The Gothic novel, at the same time, reflects and negotiates concerns about the actual spatiality of modern domesticity that accompany emerging middle-class ideologies of the ideal home. As Kate Ferguson Ellis observes in her influential study on the important role of domestic discourses for the Gothic, "it is the failed home that appears on [the Gothic novel's] pages, the place from which some (usually 'fallen' men) are locked out, and others (usually 'innocent' women) are locked in" (Ellis 1989: ix). The Gothic novel juxtaposes ideals of the 'feminine home' as a safe haven, the place in which the majority of readers of Gothic fiction - middle-class women - would actually find themselves, with the fact that this home can be a stifling prison. Gothic fiction also, however, both provides women with the means to spatially subvert the rules of patriarchal domesticity, and, as I will argue, proves the private sphere of masculine activity - the library, the closet - to be the locus of a highly problematic masculine self-conception.

Literary scholarship and criticism have long realised the potential of Gothic fiction for a productive analysis of historically contingent patterns of gendered behaviour. What is at stake in these stories is, in fact, as Donna Heiland points out, a delegitimisation of patriarchy itself: "The transgressive acts at the heart of gothic 
fiction generally focus on corruption in, or resistance to, the patriarchal structures that shaped the country's political life and its family life, and gender roles within those structures come in for particular scrutiny." (Heiland 2004: 5) I will show how Gothic fiction not only criticises the objectification of women, and their exposure to potential psychological and physical violence at the hands of patriarchal tyranny, but also constructs masculinity, in terms of patriarchal-homosocial power (economical, sexual, epistemological), as inherently paranoid and flawed. This masculinity relies on a rhetoric of homosocially shared secrecy which is, in itself, dangerously pathological (I need to protect my secret!), and becomes increasingly problematic within the discursive context of ever more virulent categories of 'deviant sexualities.' As George E. Haggerty emphasises, “[i]t is no mere coincidence that the cult of gothic fiction reached its apex at the very moment when gender and sexuality were beginning to be codified for modern culture" (Haggerty 2006: 3 ). At a time when the discursive structures of modern ideologies of gender and 'sexuality' were still in the process of being established, Gothic fiction points to the frictions and nodes of conflict that arise in an economy of desire that needs to be negotiated within an increasingly heteronormative patriarchal environment. In fact, "gothic fiction itself helped shape thinking about sexual matters" (Haggerty 2006: 3). As Ruth Bienstock Anolik suggests, in a time during which binaries of both gender and 'sexuality' were newly fleshed out, we encounter "the space of the other gender, an unknown territory that is the locus of the Gothic" (Anolik 2007: 6 ), and that becomes aligned with the space of the 'sexual other.' It will be one of the aims of this book to explore the relationship between misogyny and homophobia in the conflicted space of homo- and heterosocial relations.

In the course of the following chapters, I will explore how Gothic literature and its successors problematise the many ways in which the discursively powerful fiction of masculine supremacy is based on structures of homosocial intimacy which constantly struggle to dissociate themselves from some 'other' - women, heterosociality, homosexuality - and fail. Masculinity, in the Gothic, in its paranoid attempt to establish itself as the norm and centre of power, destabilises its own fiction of supremacy. Bluebeard faces women who sneak into his closet, and make the foundations of his house crumble. We can find manifestations of this process from the very beginnings of the genre. Taking three of the most famous and culturally influential texts from the Gothic canon, Horace Walpole's The Castle of Otranto (1764), Ann Radcliffe's The Mysteries of Udolpho (1794), and William Godwin's Caleb Williams (1794), I will analyse the already precarious position of masculinity, and its difficult relationship with normative discourses of homosocial-patriarchal secrecy in these narratives.

In the course of the nineteenth century, the themes and conventions of the Gothic novel were picked up and re-contextualised again and again by writers 
of fiction as diverse as crime, horror, and fantasy. The Gothic "scattered its ingredients into various modes, among them aspects of the more realistic Victorian novel" (Hogle 2002: 1). Victorian sensation fiction, as Henry James remarks, explores "those most mysterious of mysteries, the mysteries that are at our own doors. [...] Instead of the terrors of Udolpho, we were treated to the terrors of the cheerful country house or the busy London lodgings. And there is no doubt that these were infinitely more terrible." (James qtd. Taylor/Crofts 1998: xiv) Sensation novels relocate the horrors of the eighteenth century Gothic, and bring them from faraway regions of the Italian Alps to our very doorstep, to London, to the houses of the English aristocracy and middle classes. Supernatural elements disappear, but sensation fiction exploits and explores the same dynamics of secrecy that we find in the Gothic.

Sensation fiction, frowned upon by contemporary critics as "a self-evidently substandard literary category" (Radford 2009: 1), has, over the last decades, been increasingly acknowledged by literary scholars as a subject worth studying. Laurie Garrison places the genre at the very centre of Victorian reading culture, since "it inspired a new form of reading, one that depended first on the physical effects it inspired in the reader and secondly on the psychological effects that occurred as a result of this form of reading" (Garrison 2011: xii). Written to pleasantly shock and scandalise its readership, sensation novels, with their - often unlikely - plots revolving around adultery, incest, bigamy, illegitimacy, and deviant gender behaviour, are an invaluable source for the study of Victorian concerns with gender and 'sexual identities.' In close readings of three of the most influential works of mid-nineteenth century sensation fiction - Wilkie Collins' The Woman in White (1859/60) and No Name (1862), and Mary Elizabeth Braddon's Lady Audley's Secret (1862) - I will demonstrate how these novels, just like the early Gothic, choose domestic spatiality as the starting point to question and re-evaluate Victorian ideologies of gendered power relations. Masculinity, in particular, is heavily scrutinised by Collins and Braddon, in that women subvert the patriarchal space that holds Bluebeard's secret. Men, in these narratives of the home, are, more often than not, physically weak, ill, decadent, effeminate, and not at all in control of the knowledge that patriarchal masculinity bases its power on. Those male characters that will survive the struggle are the 'queer fish,' those who manage to liberate themselves - often through heterosocial bonds with women - from the paranoid structures of the patriarchal 'closet.' Both Collins and Braddon construct heterosocial bonds between men and women as much more stable than patriarchal bonding along the axes homosocial-heterosexual. This ideal of 'queerness,' a 'queerness' that reconfigures normative economies of desire (and power), becomes an even more central concern in Henry James' writing. 
James, famous for his tongue-in-cheek rhetoric full of innuendo and ambiguity that reverberates with all sorts of 'meanings,' has become a favourite author for queer studies. Many biographical approaches now associate his alleged homosexuality with readings of his work. James' concern with questions of gender - and of masculinity in particular - has become a subject of scholarly attention as well. Kelly Cannon begins her work on this very topic thus: "The life and work of Henry James offer a wealth of impressions to readers with eyes for the unconventional: the author and many of his male characters defy stereotypes of masculinity, asking in their varied voices if culture allows for deviation. [...] James unsettles, rather than appeases the reader's longing for conventional manhood." (Cannon 1994: 1)

James' male characters are acutely concerned with their own identity and place in the world, while a lot of their female counterparts seem much more in control of the (self-) knowledge which, in James' writing, so ominously stays just below the level of explication. What is more, James - most famously, perhaps, in "The Turn of the Screw" (1898) - consciously inscribes himself into a Gothic tradition. His use of domestic spatiality in particular places his work in the context of earlier literary manifestations of Gothic houses. James combines constructions of gendered domestic spatiality with what I will be calling a 'queer rhetoric.' His employment of language, with an excessive use of innuendo, ambiguity, and constant references to epistemological processes, shows a significant and deliberate affinity to the language of the 'closet.' What is so striking about James' rhetoric are, as Eve Sedgwick famously argues in her analysis of "The Beast in the Jungle" (1903), the absences, the painfully obvious silences, the things that are not said, which bring the narrative almost palpably close to one particular reading, which can hardly be anything but 'sexual:' 'In 'The Beast in the Jungle,' written at the threshold of the new century, the possibility of an embodied male-homosexual thematics has, I would like to argue, a precisely liminal presence. It is present as a - as a very particular, historicized - thematics of absence, and specifically of the absence of speech." (Sedgwick 1990: 201)

In my analysis of three of James' tales - "The Aspern Papers" (1888), "In the Cage" (1898), and "The Jolly Corner" (1908) - I will flesh out the semantic possibilities of exactly these silences, and show how, in James' fictional turn-ofthe-century world, Bluebeard's secret has become properly 'queer,' not in that it is 'simply' homosexual, but in that it almost violently pushes towards a 'paranoid reading' of the excessive absences as the presence of the unspeakable 'closet' that denies a heteronormative solution. James ingeniously turns his readers into 'paranoid readers.' He does not offer us any definite hints as to how to read his multiple textual uncertainties: "The denial that the secret has a content - the assertion that its content is precisely a lack - is a stylish and 'satisfyingly' Jamesian formal gesture." (Sedgwick 1990: 201) James brilliantly masters the rhetoric of the 'closet,' 
which, at the turn of the twentieth century, would have loudly reverberated with all kinds of 'sexual' meanings. He leaves it, however, to the reader to, almost involuntarily, engage in the sheer joy of maybe knowing, of maybe recognising, and offers this potentially reparative, 'queer' stance at a point in history when masculinities were faced with all kinds of 'knowledge,' sexual and otherwise, that created the need to 'speak one's name,' be it heterosexual or homosexual. James opts for neither, and presents us with a vision of a denial of knowledge that is both productive and liberating.

The fictional discourses I will be tracing here reveal a lot about eighteenth and nineteenth century English culture as a whole. Gothic fiction, thanks to its rich array of imagery and psychological density, lends itself particularly well for an analysis of the cultural state of mind at a certain historical moment. At the same time, fiction has itself always contributed to shaping the way we understand the world around us. So, when it comes to questions of gender and 'sexuality,' Gothic fiction, and the traditions succeeding it not only reflect certain discursive modes of the time, but are voices of their own, which helped create our current understanding of these matters: "[G]othic fiction anticipates the history of sexuality and gives that history its most basic materials. [...It] was the testing ground for theories of individual psychology before that psychology was fully articulated." (Haggerty 2006: 5; 44) In the course of the following chapters, I hope to establish a grid of dynamics that will help shape a better understanding of the ways authors negotiated notions of desire, identity, and power during a time in European history in which our current set of terms and ideas concerning genders and 'sexualities' first came into being.

\section{Methods: Secrecy, Sexuality, and Liminal Spaces}

\section{The Language and Culture of Secrecy}

A historical account of how privacy emerged in its modern form has given us an idea of the prerequisites for a cultural preoccupation with individual secrecy. Privacy, in fact, creates secrecy. It provides actual and mental spaces in which secrets can be kept. The two notions should not, however, be treated as semantically equivalent. It is, therefore, worth stopping for a moment to think about what the differences between privacy and secrecy are. Stanton K. Tefft's claim that "privacy involv[es] voluntary concealment and secrecy involv[es] obligatory concealment" (Tefft 1980a: 13) is not universally applicable. After all, the Sexual Offences Act of 1967, which decriminalised homosexual acts between consenting 
adults in England, only did so under the condition that these acts be performed in private. This form of privacy is neither voluntary, nor is it a secret in the strictest sense. Secret societies, like the freemasons, on the other hand, keep their secrets not because they are afraid of the consequences of someone revealing a socially unacceptable truth, but as a means of power. The differences between privacy and secrecy, then, must lie elsewhere.

Carol Warren and Barbara Laslett point out that privacy and secrecy are valued differently concerning their moral dimension. While secrets are usually kept because what they contain has a negative moral value, either for the person keeping the secret, or for those from which the secret is kept (or, of course, both), private behaviour is valued either neutrally or positively: "Privacy has a consensual basis in society, while secrecy does not." (Warren/Laslett 1980: 27; cf. Tefft 1980b: 320-321; 333) This distinction, however, must also take into account the overlap of privacy and secrecy where the moral value of the act or knowledge concealed is unclear. Privacy is supposed to create a space in which socially legitimised acts or knowledge can be protected from the invading gaze of the 'public.' This logic, however, always makes private space potentially secret space, because who knows what goes on behind my neighbours' curtains (cf. Warren/Laslett 1980: 28)?

It appears that our culture has grown accustomed to respecting the boundaries of privacy to the extent that what is known to be private is nobody else's business. "That which is restricted by secrecy, however, is more likely to be regarded as legitimate public property that must be concealed or hidden illegitimately through secrecy." (Warren/Laslett 1980: 27) Secrecy is perceived as a threat to the social order, while privacy is not. Since, however, modern privacy is structured such that it always holds the potential for secrecy, the promise of an inviolable private space becomes a myth: curiosity does not stop at the doorstep of the private. The modern bourgeois home invites us to want to know what is going on inside. We imagine all kinds of secrets lurking in its locked rooms and closets. Here, within the space of modern domesticity, privacy and secrecy overlap to an extent that explains the popularity of Gothic and sensation fiction from the eighteenth century onwards, genres famously preoccupied with the secrets hidden in the privacy of castles, or the urban homes of men, and depicting characters trying to conceal or reveal these domestic secrets.

The position of the secret holder is not always disadvantageous. Warren and Laslett claim that "the most successful secret occurs when knowledge of denial of access (the secret's very existence) is also withheld" (Warren/Laslett 1980: 27). This, however, is not necessarily true. First of all, a secret only becomes a secret if knowledge of it (the secret as such, not its content) is accessible to more than just the person holding it. Secondly, this kind of negative definition of secrecy completely disregards both the empowering potential of secrecy ('I know some- 
thing you do not, and, hence, I have a certain amount of power over you.'), and the socially perfectly accepted and functioning forms of 'open secret' structures ('We both know, but as long as we do not mention it, we do not have to acknowledge it.') that exist in our culture.

Why, then, does private secrecy hold such a subversive potential? The question brings us back to the emergence of modern 'sexualities,' and the predominance of sex as the knowledge of our times. The modern private sphere created spaces the individual could withdraw to. What was going on in the secluded home and the secluded mind was becoming a matter of interest and speculation to those excluded from them. If somebody had something to hide, if a certain knowledge was such that it was kept in the most private and hidden spaces of the modern home and the mind, what could this knowledge be if not a person's - especially a man's - 'sexual' self; and sex, within the modern regime of discourses, is never a mere 'private' matter. The modern homosexual 'closet' owes its emergence to various processes, among which the creation of the bourgeois private sphere is one of the most important ones. Before discussing the structure of the 'closet' in more detail, however, and in order to fully understand how secrecy works, and how it stands in relation to private mental and actual space - especially in the form of the homosexual 'closet' - it will be necessary to have a closer look at the structure and rhetoric of secrecy itself.

We have established that privacy and secrecy are different from, but also connected to each other. Privacy provides an environment in which secrecy can flourish. What, however, is the particular cultural role of secrecy itself?

"Secrecy is established to protect information or to conceal knowledge of acts or relationships that outsiders have an interest in, for whatever reasons, and that they are capable of acquiring without the consent of the secret holders by espionage. To understand what secrets are concealed we must find out who conceals them - and from whom and for what purpose." (Tefft 1980a: 14)

Tefft's definition is a good starting point, because it is neutral. The decision to keep a secret can be voluntary or forced (or something in between), and keeping the secret can be a threatening or an empowering experience (or both): "[S]ecrecy enables individuals and groups to manipulate and control their environments by denying outsiders vital information about themselves." (Tefft 1980a: 15; cf. Tefft 1980c: 35) Keeping a secret can be a necessity - in order to avoid punishment or stigmatisation (cf. Tefft 1980c: 36) - but still lead to an increase in personal power. What counts is not primarily the content of the secret, but the fact of its being one: "[S]ecrets, whatever their nature, give the secret sharers a power over those outsiders who think the secret information is vital to their own interests and, thus, want 
to discover what it may be." (Tefft 1980c: 37; emphasis mine) It does not matter whether the concealed knowledge is actually vital to the interests of the outsiders as long as they think it is.

The emergence of a modern private sphere in Europe paved the way for a heightened appreciation of, and preoccupation with secrecy. David Vincent suggests that British culture, in particular, has traditionally been shaped by issues of secrecy, developing a "particular British tradition of clothing secrecy in secrecy" (Vincent 1998: ix). Albert D. Pionke, too, assumes that, especially in the Victorian period, British culture was particularly secretive, ranging from issues of social control and government censorship, to the preoccupation with shame and criminality, and an aesthetic appreciation of secrecy as a privilege (cf. Pionke 2010: 8-9). Secrecy, in nineteenth-century Britain, became a 'gentlemanly' quality of the upper-middle classes. An English gentleman was 'discreet.' The ability to keep secrets and manage information came to be considered a positive character trait: "[T]hose accorded the public status of gentlemen had subtly to indicate that they were reserving an essential part of their characters from the public gaze." (Pionke 2010: 3) Unsurprisingly, it was the very class which also profited most from the emergence of a new private sphere that came to value secrecy most. Again, a culture of privacy was a prerequisite for the development of a culture of secrecy. Secrecy in Britain was not just a matter of politics, but of culture, "more a cultural than an institutional phenomenon" (Minkley/Legassick 2000: 3).

Keeping secrets affords a high amount of mental information management, it influences the way people interact with one another: "Secrets are negotiated: continual decisions about whom to tell, how much to tell, and who not to tell describe social worlds, and the shape and weight of interactions therein." (White 2000: 11) Keeping a secret is not simply an individual activity, it is a form of social communication. Similarly, lying affords more creativity than telling 'the truth,' and, hence, tells us a lot about someone's character. "Lying is about deliberation and concealment and lies have to be crafted, negotiated as well as durable. Secrets and lies, then, not only tell stories in the 'not telling,' but also [...] often tell a lot, indeed often a lot more than "telling." (Minkley/Legassick 2000: 7) Behind a secret or a lie there is always a conscious decision, an agenda. Secret information is given special attention and value that differentiates it from information that is commonly shared:

"Telling lies and proclaiming and keeping secrets [...] are decisions to make certain information so charged that its value and importance is unlike that of other information. Lies and secrets are explanations about the past that are negotiated for specific audiences, for specific ends. Secrecy and lies conceal, they camouflage, but they certainly do not hide everything." (White 2000: 15) 
There are reasons why people keep knowledge to themselves, share it with just a few others, or tell lies. Secrets and lies can shape a person's life and personality. This is especially true for the secret of all secrets in modern, 'sexualised' culture: the male homosexual 'closet.'

Apart from Eve Sedgwick's theory concerning the 'closet,' which I will discuss in detail below, nobody has, so far, fundamentally analysed the workings and effects of a more general masculine secret beyond a 'mere' homosexual reading. Sedgwick's analysis of the 'closet' cannot be applied to earlier forms of masculine secrecy, since it presupposes the development of modern discourses of 'sexuality.' Here lies a fundamental deficit in theory.

A possible starting point for developing a more general theory of a masculine secret is Jacques Derrida's essay "How to Avoid Speaking: Denials," in which he deals with the question of how it is possible to speak about something that is unspeakable. He starts his argument by discussing the Platonic theory of 'negative theology:' "Negative theology consists of considering that every predicative language is inadequate to the essence, in truth to the hyperessentiality (the being beyond Being) of God; consequently, only a negative ('apophatic') attribution can claim to approach God, and to prepare us for a silent intuition of God." (Derrida 1989: 4)

God, in this view, is neither a positive existence nor non-existent: God 'is' above, before, beyond being. Derrida criticises 'negative theology' for reserving a kind of 'hyperessentiality' for God, hence not letting go of God's 'existence' (cf. Derrida 1989: 7-10). However, he uses the assumptions of 'negative theology' as a stimulus for a discussion of how it is possible to speak about something that cannot be spoken about, since every speech act that includes the unspeakable presupposes its existence.

At a crucial point in his essay, Derrida talks about secrecy: "In certain situations, one asks oneself 'how to avoid speaking,' either because one has promised not to speak and to keep a secret, or because one has an interest, sometimes vital, in keeping silent even if put to the rack. This situation again presupposes the possibility of speaking." (Derrida 1989: 16-17)

The secret, then, is itself structured such that it only exists by presupposing the possibility of verbalising it. The secret only comes into being through a politics of hiding, by denying its content. Derrida does not want to face the challenge of exploring in detail the workings of the secret: "I will not take up this immense problem here." (Derrida 1989: 17) Nevertheless, he sufficiently hints at the powerful potential of secrecy: a person's mind, according to Derrida, is the space "in which is retained the singular power not to say what one knows, to keep a secret in the form of representation. A conscious being is a being capable of lying, of not 
presenting in speech that of which it yet has an articulated representation: a being can avoid speaking." (Derrida 1989: 17)

The secret's potential power lies in the presupposed verbalisation that gives the secret its shape: "To keep something to oneself is the most incredible and thought-provoking power." (Derrida 1989: 18) At the same time, the secret is constantly in danger of being uncovered: "Does one ever have at one's disposal either sufficient criteria or an apodictic certainty that allows one to say: the secret has been kept, the dissimulation has taken place, one has avoided speaking?" (Derrida 1989: 18). Power based on secrecy is always precarious, because, rhetorically, the secret is a void: as an act of communication, saying that one will not say something leaves open to speculation what that something might be. Others can fill the secret with a meaning that lies beyond the control of the secret holder. Secrecy always means both power and paranoia, and this becomes especially problematic in the course of the nineteenth century, when discourses of binary 'sexual identities' become increasingly virulent, and a masculine secret is more and more in danger of being read as the secret of the male-homosexual 'closet.' The 'speech act' of masculine secrecy becomes prone to be read in only this one way, no matter if the secret really is that.

\section{The Modern Homosexual 'Closet'}

In 1990, Eve Kosofsky Sedgwick published Epistemology of the Closet, which triggered a fruitful debate in post-structuralist gender and queer studies that has not yet been sufficiently absorbed by research on Gothic spatialities. Originally due to her interest in post-AIDS discussions in the 1980s on the 'outing' of homosexuals, Sedgwick investigates the epistemological preconditions and social consequences of a gay 'coming out' in the Western world. In doing so, she - following Foucault - diagnoses an "endemic crisis of homo/heterosexual definition" (Sedgwick 1990: 1) since the end of the nineteenth century, stating that, for about a hundred years, thinking and knowledge in our society has centred on the question of 'sexuality,' and, particularly, on whether somebody is 'gay' or 'straight.' Without this definitional tension in late-nineteenth and twentieth century society, she believes, "an understanding of virtually any aspect of modern Western culture" (Sedgwick 1990: 1) is impossible.

In contemporary Western society, everybody is implicitly required to define themselves as either 'homosexual' or 'heterosexual' - with 'bisexuality' not substantially challenging the rigidity of this compulsory definitional grid. The discursive pressure to label yourself, and be labelled by others, according to preconfigured categories, and the moral value attached to them produce the 'closet,' the 
secret, the space in which 'sexuality' is not named or spoken. To be 'in the closet,' however, not to be 'out,' does not mean that definition can be entirely dodged. The silence speaks for itself: “'Closetedness' itself is a performance initiated as such by the speech act of silence - not a particular silence, but a silence that accrues particularity by fits and starts, in relation to the discourse that surrounds and differentially constitutes it." (Sedgwick 1990: 3) The silence of the 'closet' is always in dialogue with the surrounding discourses of 'sexual' definition. One of Sedgwick's aims is to demonstrate how instable and alterable these historically contingent, and ever-changing definitions are, and to show that a binary model of homo- and heterosexual self-definition is insufficient to cover the rich array of human desire: "Axiom 1: People are different from each other." (Sedgwick 1990: 22) Following Sedgwick's line of thought, I will be tracing the textual evidence of strategies through which authors of fiction have variously embraced and avoided, questioned and distanced themselves from the categories available to them to describe human gender, power relations, and forms of desire.

Doing close readings of several canonical literary texts, Sedgwick shows that discourses of homoeroticism and 'homosexuality' are not at all only found on the fringes, as exceptions, anomalies, but, on the contrary, they are part of, and even constitute the very heart of the Western literary canon. Deliberately exaggerating and simplifying the complex history of male-male desire, Sedgwick assesses that "not only have there been a gay Socrates, Shakespeare, and Proust but [...] their names are Socrates, Shakespeare, Proust" (Sedgwick 1990: 52). Despite the obvious historical haziness of this claim, Sedgwick rightly points out the irony of a large part of modern, heteronormative historical research and literary criticism: whenever critics discover the - often powerful - homoerotic undertones of any given narrative, they declare them not to be important, either because, at a certain point in history, homoeroticism was, supposedly, 'normal,' or because the text's homoeroticism is marginal. In historical and cultural meta-discourse, hence, according to Sedgwick, voices that universalise homoeroticism ('Homosexuality is everywhere.') often appear simultaneously with ones that minoritise it ('Homosexuality is limited to a small group of people.') (cf. Sedgwick 1990: 48-59).

Sedgwick wants to work against this contradictory phenomenon of dodging and denial, and refuses to position herself with either of the two extreme voices. She realises how meaningful and central homoerotic relationships (especially between men) have been in Western cultural and literary history. For a productive appreciation of this history, then, it is crucial to be aware that "[t]he stimulation and glamorization of the energies of male-male desire is an incessant project that must, for the preservation of that self-contradictory tradition, coexist with an equally incessant project of denying, deferring, or silencing their satisfaction" (Sedgwick 1990: 56). 
Sedgwick positions her close readings in the context of this tension between the denial and omnipresence of homoerotic and homosexual relationships between men. For not only do readers often ignore the homoerotic subtext of a lot of writing, but authors themselves have turned ambiguity into an art. When homoeroticism became increasingly unspeakable in a culture that created ever more rigid pathological definitions of aberrant 'sexual' behaviour, and same-sex desire became the 'open secret' that could only be hinted at, known, but not spoken, writers turned to innuendo. In the vicinity of the 'closet,' contradictions between knowledge and ignorance, secrecy and betrayal, power and impotence emerge: "The position of those who think they know something about one that one may not know oneself is an excited and empowered one." (Sedgwick 1990: 80) While the 'closet' is a - textual and cultural - space whose readability the person 'in the closet' cannot control, the same holds vice-versa: the 'closet' provides a space of possibility, within which a language of secrecy and half-knowledge can make somebody 'readable' only to those who are looking for a particular meaning. It takes one to know one.

As we have seen earlier, same-sex desire, naturally, did not suddenly come into being in the age of modern discourses on 'sexuality.' It is only, however, with the emergence of modern notions of 'sexual identities,' and in the context of a new private sphere, that the 'closet,' in its fully-fledged modern shape, appears. The nexus of homosociality and homoeroticism is gradually transformed into a 'sexual' dichotomy that becomes - especially for men - unsurpassable.

Sedgwick points out the crucial importance of the homosexual 'closet' as an abstract space in which power over knowledge is negotiated: "[I]gnorance is as potent and as multiple a thing there as is knowledge." (Sedgwick 1990: 4) Her book includes, apart from her theories, 'closet readings' of several central works of English and American literature, for example of Melville's Billy Budd Sailor, and, as mentioned above, James" "The Beast in the Jungle" (cf. Sedgwick 1990: 91-130; 182-212). This (successful) search for the 'closet' at the heart of the Western literary canon suggests that the sexualised male secret is a basic constant of modern English society. Over the last years, many authors, following Sedgwick's example, have done 'closet readings' of other works of literature, and the 'closet' is now an integral part of modern gender and queer studies. Even before Sedgwick published her extensive theoretical framework, Ed Cohen did a 'closet reading' of Oscar Wilde's The Picture of Dorian Gray, in which he illustrates "that even in the absence of explicit homosexual terminology and activity, a text can subvert the normative standards of male same-sex behaviour[..., evoking possibilities for male samesex eroticism without explicitly voicing them" (Cohen 1987: 803; 809). Cohen also already makes explicit what a 'closet rhetoric' could mean for writers who work in a society that does not allow for an open literary discourse on same-sex desire: 
"To the extent that Wilde and contemporaries like him were beginning to articulate strategies to communicate - both to themselves and to others - the experience of homoerotic desire, their texts enact and virtually embody this desire. But since these men were also writing within a larger culture that not only denied but actively prosecuted such embodiments, they were forced to devise ways to mediate their expressions of passion." (Cohen 1987: 810)

The nineteenth century, in particular, then, sees an accumulation of texts that consciously play with their simultaneous obscurity and 'readability.' Sedgwick, however, is not concerned with investigating the historical roots of this phenomenon, which she firmly places in the nineteenth century. It is surprising that, so far, there has hardly been any research on the cultural roots of the 'closet.' No one has yet sufficiently noted that the 'closet,' as an omnipresent male secret, has its roots early in our cultural history, roots that reach far beyond the nineteenth century 'open secret' of homosexuality. Discourses on both individual privacy and secrecy, and 'sexual' categorisations, as I have demonstrated above, begin to become virulent as early as in the eighteenth century.

Alan Stewart was the first to explicate the connection between the metaphorical 'closet' of modern homosexuality, and earlier, actually localisable spaces of secrecy - literal closets. He shows that "the crisis of the epistemology of the closet in the early 1990s is inherent to and prefigured in the closet as architectural reality and topos in sixteenth century England" (Stewart 1995: 77). Sedgwick's list of meanings of the word 'closet' from the OED (cf. Sedgwick 1990: 65) had already hinted at the fact that the new privacy of the early modern closet, and its potential as a secret space are the historical link between metaphor and actual space of the 'closet.'

This very particular domestic space, while serving as a room of withdrawal for one individual, is also - and for our purpose most crucially for men - a homosocial space, in which intimate exchanges of information take place. It is "a secret non-public transactive space between two men behind a locked door" (Stewart 1995: 83).

Stewart draws particular attention to the role of the secretary - etymologically the keeper of secrets - whose relationship with his master appears, in early modern writings on the subject, not exclusively professional. Intimacy and friendship are conflated with patronage and service in such an unusual way that this relationship becomes a prototypical same-sex relationship that does not comply with the normative codes of its society, and can only exist in the vicinity of a particular private space, the closet (cf. Stewart 1995: 83-87). Even contemporaries seem to have felt uneasy about the potentially 'sexual' contents of the secrets hidden behind the closed doors of the closet. A lady's closet that male servants had access to could 
figure as the female-male model of a more subtly perceived anxiety about what might be going on in the homosocial space of the male closet (cf. Stewart 1995: 87-89). The homosocial secrets shared in this private space become dangerously readable within the discursive context of 'sodomy,' 'mollies,' and, later, 'homosexuality.'

What is more, the secrecy of the closet makes it particularly intriguing for outsiders: "Far from rendering relationships and transactions secret, the closet paradoxically draws attention to those relationships and transactions and marks them off as socially and even ethically problematic." (Stewart 1995: 93) It is not surprising, therefore, that the secret space of the closet served even contemporaries as a metaphor, one that has survived to our days, most prominently - and not in the least by coincidence - as the male homosexual 'closet.' The changes and continuities in the relationship between the spatial and metaphorical qualities of the 'closet' will be the central theme of the following close readings. I will be tracing the ways authors have employed actual domestic spaces as metaphors for the secret spaces of the mind, how power over knowledge is negotiated within, without, and via these spaces, and how writers establish a 'queer rhetoric' that productively plays with the ambiguous readability of a 'closet' that never fully says what it means.

\section{Heterosexuality - Homosociality / Homosexuality - Heterosociality}

We have, so far, established that, with the advent of modern forms of individual privacy, and ever more influential and discursively powerful definitional terms for same-sex desire, men, in particular, increasingly faced the challenge to actively dissociate themselves from any kind of 'deviant identity' or behaviour. We have also seen that this tension created the 'closet,' a rhetorical space which, rooting in early forms of actual patriarchal private space, became more and more 'sexualised.' Before further discussing the paranoid dynamics of the 'closet,' I would like to draw attention to the changes patriarchal power structures underwent within the problematic discursive grids of modern 'sexual' categorisations.

Again, Eve Sedgwick is a very useful starting point. In her 1985 study Between Men, in which she investigates the literary history of male-homosocial desire, she posits "the potential unbrokenness of a continuum between homosocial and homosexual - a continuum whose visibility, for men, in our society, is radically disrupted" (Sedgwick 1985: 1-2). Not only does she demonstrate that, before the emergence of the modern 'homo-hetero' split, there is a potential for liveable desire in male-male relationships, but, for her, the whole system of patriarchy depends, to a considerable extent, on the ambiguous currents of desire inherent in male-homosocial bonding. Sedgwick, referring to René Girard's work (cf. Girard 1972), 
shows that the common literary trope of erotic triangles - the rivalry of two men over a woman - not only expresses heterosexual desire, but holds the potential for an equally intense emotional bond between the rivals: "[I]n any erotic rivalry, the bond that links the two rivals is as intense and potent as the bond that links either of the rivals to the beloved: that the bonds of 'rivalry' and 'love,' differently as they are experienced, are equally powerful and in many senses equivalent." (Sedgwick 1985: 21)

Quoting Gayle Rubin (cf. Rubin 1975), Sedgwick claims that women, in these kinds of patriarchal same-sex bonds, are reduced to objects through which homosocial relations can be cemented in accordance with the rules of heteronormativity: "[P] atriarchal heterosexuality can best be discussed in terms of one or another form of traffic in women: it is the use of women as exchangeable, perhaps symbolic, property for the primary purpose of cementing the bonds of men with men.” (Sedgwick 1985: 25-26)

Throughout her book, Sedgwick investigates the relationship of 'homosociality' and 'homosexuality' in texts from the Renaissance to the beginning of the twentieth century. The changes she traces in these literary discursive examples the way the 'homosocial'-'homosexual' continuum was reshaped over the course of a few centuries - can serve as a starting point for any literary investigation of modern - and especially male-male - same-sex desire. Sedgwick skilfully exposes one of the most central traumas of modern patriarchal culture, which is closely linked to the dynamics of the 'closet:' patriarchy, according to Sedgwick, on the one hand, heavily depends on close homosocial bonds between men, which, for much of our history, have, in their physical and emotional expressions, often bordered closely on what, today, would be perceived as 'homosexual' (cf. e.g. Bray 2003; Hammond 2002). On the other hand, it seems that "homophobia is a necessary consequence of such patriarchal institutions as heterosexual marriage" (Sedgwick 1985: 3). As Sedgwick demonstrates, however - and as we have seen above - homophobia, just as same-sex desire itself, has been structured differently at different points in history. Physical expressions of love between men, for example, were positively sanctioned in Greek antiquity, as long as they had "an educational function" (Sedgwick 1985: 4). "The radically discontinuous relation of male homosocial and homosexual bonds" (Sedgwick 1985: 5), then, is a fairly recent phenomenon. While modern English patriarchal society, from the eighteenth century onwards, has continued to depend on strong emotional, political, economical, intellectual, and, crucially, secretive bonds between men, it has increasingly - indeed paranoiacally - striven to set itself apart from the charge of 'homosexuality:' "Because the paths of male entitlement, especially in the nineteenth century, required certain intense male bonds that were not readily distinguishable from the most reprobated bonds, an en- 
demic and ineradicable state of what I am calling male homosexual panic became the normal condition of male heterosexual entitlement." (Sedgwick 1990: 185)

I would like to extend Sedgwick's analysis of the homosocial-homosexual split, and make it productive for my following close readings. We can complement the nodes 'homosocial,' 'homosexual,' and 'heterosexual' with a fourth node, which will re-establish a definitional balance between what, in English patriarchal society, is deemed 'normative' or 'deviant.' If 'normative masculinity' is supposed to act and define itself as 'homosocial' and 'heterosexual,' then 'deviant masculinity,' we can assume, would not only be considered 'homosexual,' but also 'heterosocial.' A 'queer' denial of heteronormative, patriarchal masculine behaviour, which finds one of its most powerful literary expressions in Henry James' turn-of-thecentury writing, is not only (or not even necessarily) 'gay,' but it is also excessively 'heterosocial,' in that non-sexual, intellectual, emotional, economical, and political bonds between men and women substitute the heterosexual marriage plot. This is a radical move in many respects: it admits women into the political sphere of knowledge exchange, and makes them secret sharers; it refuses supposedly 'natural' reproductive sexuality; and it affords a space for 'queer' masculinities, without having to step out of the 'closet,' 'come out,' and embrace a more blatantly pathologised 'homosexual' identity. A concept of 'heterosociality' as a subversive stance also, and maybe most importantly, supports Sedgwick's central observation that "homophobia directed by men against men is misogynistic" (Sedgwick 1985: 20). Shifting the erotics of the body to same-sex relations, and, at the same time, admitting women into the realm of epistemological power politics, 'queer' writings potentially not only alleviate the objectification of women as either consumed sexually, or traded in the interest of furthering the bonds between men, but also subvert the patriarchal ideal of strictly homosocial secret power politics, affording women the power to act on their own account (sexually and politically). As such, paranoid patriarchal masculinity must beware of its secret being read as both 'homosexual' and 'heterosocial.'

\section{The 'Paranoid Reader'}

It should be sufficiently obvious by now that there exists not only a connection between masculine secrecy and the Gothic, but also between the emerging 'sexual' secret of 'homosexuality' and masculine secrecy in general, and, hence, between the 'homosexual' secret and the Gothic. If we want to conceptualise this link, we might call it 'paranoia.' Eve Sedgwick emphasises the central crux of modern homosocial-homophobic masculinities: "For a man to be a man's man is separated only by an invisible, carefully blurred, always-already-crossed line from being 
'interested in men."' (Sedgwick 1985: 89) The constant need for men to simultaneously rely on secretive bonds with other men, and dissociate themselves from the charge of 'homosexuality' leads to what Sedgwick calls "homosexual panic" (Sedgwick 1985: 89), the paranoid need to avoid being 'read' as that 'sexual other,' which is unnameable. The Gothic, for Sedgwick, is the literary expression of this particular form of modern masculine paranoid self-conception: "[P] aranoia is the psychosis that makes graphic the mechanisms of homophobia. [...] The Gothic novel crystallized for English audiences the terms of a dialectic between male homosexuality and homophobia, in which homophobia appeared thematically in paranoid plots.” (Sedgwick 1985: 92; cf. Sedgwick 1990: 186)

Although I agree with Sedgwick's analysis of homophobia's central role in Gothic narratives, I would like to argue that the paranoid mechanisms she describes as inherent in modern masculinities are, in fact, most problematic not due to their being closely associated with the workings of homophobia, but because paranoia as such is an integral part of patriarchal power structures. In other words, masculinity was phobic before it was homophobic. Let us remind ourselves for a moment of the Bluebeard tale. Bluebeard's 'closet' is paranoid not because it is 'homosexual' - it is, in fact, not even homosocial - but because his power relies on the existence of an impenetrable secret space. The mere fact of his having a space (and knowledge) that is out of bounds to his wife cements his 'heterosexual' power and control over her. The modern masculine 'closet,' then, is both powerful, and paranoid, both a prerequisite to the self-legitimation of homosocial-patriarchal dominance, and a source of incessant 'homosexual panic.'

One of Sedgwick's more recent texts will prove a useful additional tool for a detailed analysis of the paranoid dynamics in the works discussed below. Her 2003 collection Touching Feeling contains a revised version of her essay "Paranoid Reading and Reparative Reading, or, You're So Paranoid, You Probably Think This Essay Is About You," in which she diagnoses current research in the humanities with a pathological need to find 'meaning' in everything, and make 'knowledge' explicit: "[P]aranoia has by now become less a diagnosis than a prescription." (Sedgwick 2003: 125) Sedgwick actively positions herself against the unearthing of still more positive 'truths,' and posits that "to practice other than paranoid forms of knowing does not, in itself, entail a denial of the reality or gravity of enmity or oppression" (Sedgwick 2003: 128). She then calls for "reparative readings' of history, literature, etc., and an appreciation of "the devalued and near obsolescent New Critical skill of imaginative close reading” (Sedgwick 2003: 145). Ascribing a higher value to non-linear discourses, and avoiding a 'phobic' and 'paranoid' epistemology, which looks for 'meaning' and 'knowledge,' while avoiding surprise, we might, Sedgwick believes, arrive at a more creative and fruitful understanding of "the many ways selves and communities succeed in extracting 
sustenance from the objects of a culture - even of a culture whose avowed desire has often been not to sustain them" (Sedgwick 2003: 151).

I will be using Sedgwick's concept of the 'paranoid reader' on several analytical levels. Generalising her idea that a dominant mode of 'paranoid epistemology' looks for meaning everywhere to make it work for both textual (the writing itself) and psychological (the characters) analyses, and combining it with the very particular dynamics of the paranoid 'closet' of modern masculinities, I will locate the 'paranoid reader' in three instances. Firstly, the Gothic male himself is a 'paranoid reader' of his own character, in that he feels the need to 'read' himself according to available discourses on accepted or 'deviant' gender and 'sexual' identities. He is both paranoid ('reading') subject, and paranoid ('read') object, since he also lives in constant fear of what his secret might be 'read' as by others. Secondly, other characters, the female Gothic heroine in particular, are 'paranoid readers' par excellence. Their curiosity and thirst for knowledge make them want to penetrate the masculine secret at stake, and 'read' its holder in terms of an epistemology of power. Thirdly, on a textual level, the narratives discussed here play with their reader's desire to penetrate their meaning, and 'know' their secrets. The Gothic 'closet' playfully asks us to 'read' it, fill it with meaning, while, at the same time, denying us immediate gratification, only revealing its secrets at the very end, or, in fact, not revealing them at all.

This textual space of possibility, I would like to argue, is where 'queer readings' become possible. As long as definite 'meaning' is suspended, our paranoid tendency to fill the gaps with 'sense,' which we draw from dominant discourses we associate with the textual context, will constantly and productively fail, and almost any kind of 'meaning' becomes possible. Or rather, by denying us definite 'truths' about its secrets, a text can negate the comfort of confirming or preferring one reading. In terms of the tension between homosocial-heterosexual versus heterosocial-homosexual readings, a text can either open up a space for both readings, and then confirm one in the end, or the 'truth' may remain ambiguous, and the reader (un)comfortably (dis)satisfied. A plot can, for example, explore the possibilities of a homoerotic dynamic, and then end with either a confirmation of the heteronormative marriage plot, an 'ironic' confirmation of the same, or no confirmation at all. What counts is the textual space in-between, the gaps, the secrets, the points that leave it to us to assign 'meaning,' to apply our paranoid need to 'know.' These textual strategies are already inherent in the Gothic, and, in the course of the nineteenth century, writers increasingly employ them deliberately to various ends - to create suspense in crime fiction, to trigger surprise, or to open up a space for socially problematic readings. Writers of homoerotic subplots - most prominently Henry James - can explore the titillating erotics of a 'queer rhetoric' that either cannot, or simply will not say what it 'means.' Here, I would like to 
argue, lies the potential for both reparative writing, and reparative readings. In my textual analyses, I will be trying not to point to any one meaning of a certain 'textual secret,' but to call attention to the many ways in which texts can open up possible readings, and, at the same time, emphatically deny and foreclose any kind of straightforward, normative, 'easy' reading. This is where the paranoid 'closet' can be positively re-evaluated, and become a space of exciting opportunities, a veritable 'other space.'

\section{Beyond Silence: Heterotopias}

The textual 'other spaces' which an anti-paranoid, non-phobic rhetoric generates, lead us back to the fictional architectures that metaphorically create the masculine 'closet' under discussion. The tales and novels examined here not only increasingly work towards a 'reparative,' non-linear mode of writing and reading, but also, within their fictional world, produce spaces which provide their characters with a certain amount of freedom from both the paranoid spatiality of the domestic masculine 'closet,' and the normative discourses associated with it. In all of the texts I will be analysing, we find a juxtaposition of the stifling, rigid, normative, secretive, and paranoid domestic, and the outside, the garden, the seaside, the city, spaces that enable characters to speak, and to deviate from their prescribed (gendered and 'sexual') roles. These liminal spaces, the non-normative, enabling places on the margins of the domestic, can best be conceptualised in terms of Foucauldian 'heterotopias.'

Foucault's own definition of the term is contradictory and problematic, not least because his longest explicit reference to the concept is his 1967 lecture "Des Espaces Autres," which was never intended for publication, and was only published, more or less unchanged, in 1984. Here, Foucault gives the following definition:

"There are also, and probably in every culture, in every civilization, real places, actual places, places that are designed into the very institution of society, which are sorts of actually realized utopias in which the real emplacements, all the other real emplacements that can be found within the culture are, at the same time, represented, contested, and reversed, sorts of places that are outside all places, although they are actually localizable. Because they are utterly different from all the emplacements that they reflect or refer to, I shall call these places 'heterotopias.'” (Foucault 1994: 178)

Heterotopias are both separated from, and part of all other actual spaces. They exist within and without society. Foucault defines two types of heterotopia: 'crisis 
heterotopias,' "privileged or sacred or forbidden places reserved for individuals who are in a state of crisis with respect to society and the human milieu in which they live" (Foucault 1994: 179), and 'heterotopias of deviation,' which have, according to Foucault, almost completely replaced 'heterotopias of crisis' in our society. He emphasises the central role of this second type of heterotopia as spaces "in which individuals are put whose behavior is deviant with respect to the mean or the required norm" (Foucault 1994: 180). As examples of 'heterotopias of deviation,' he gives rest homes, psychiatric hospitals, and prisons, the generalised 'closets' of society, so to speak, in which an individual is put to be separated from the rest of the 'normal' crowd, and silenced.

Foucault also, however, acknowledges the enabling potential of heterotopias: "The heterotopia has the ability to juxtapose in a single real place several emplacements that are incompatible in themselves." (Foucault 1994: 181) Heterotopias are liminal spaces that simultaneously exist within society, and without, they have to adhere to its rules (they are no utopias), and do not. Gardens, museums, archives, libraries, theatres, and fairs are transitory spaces, spaces in which time either expands or contracts, spaces out of the ordinary, which temporally suspend the laws and notions we live by. The ship, for Foucault, is the best example of such an in-between space: "[T] he ship is a piece of floating space, a placeless place, that lives by its own devices, that is self-enclosed, and, at the same time, delivered over the boundless expanse of the ocean. [...T]he ship [...is] the greatest reservoir of imagination. The sailing vessel is the heterotopia par excellence." (Foucault 1994: 184-185)

From the 'queer' point of view of a 'reparative' search for enabling spaces within a system of ever more rigid and pathologising notions of 'normative' and 'deviant' genders and 'sexualities,' heterotopias become particularly productive. In the following close readings, I will be exploring how, from the earliest examples of Gothic writing, up to the 'queer' work of Henry James, the paranoid domestic architectures of Bluebeard's closet get juxtaposed with liminal spaces that enable characters to act, speak, and think more freely. The garden, in particular, suspended between nature and culture, the outside and the inside, the public and the private, the wild and the domestic, simultaneously highlights and suspends these binaries, and becomes a liberating space. The domestic, very much along the lines of McKeon's 'devolution of absolutism,' becomes the locus of patriarchal, heteronormative, homophobic paranoia. Bluebeard's castles, just as Collins' houses, are no 'safe haven' for either men or women. Women, oppressed in Walpole's and Radcliffe's labyrinthine architectures, learn to subvert these structures, and find out their secrets. Men, stuck in the 'closet' of paranoid masculinity, lose control over the domestic space that defines their gendered supremacy. The garden, the seaside, the city, and the graveyard become the spaces in which epistemological 
power relations are renegotiated, and in which, for men, a 'queer' existence beyond the narratives of homosocial heternormativity and the paranoid 'closet' becomes imaginable, speakable, and liveable. As 'reparative spaces,' then, heterotopias enact spatially what 'reparative' writing and reading practices achieve textually: a space of the ambiguous, the productively and disarmingly non-normative, which engenders new ways of knowing: "By juxtaposing and combining many spaces in one site, heterotopias problematize received knowledge by revealing and destabilizing the ground [...] on which knowledge is built." (Topinka 2010: 56) As such, heterotopias enable the 'other ways of knowing' Sedgwick calls for in her plea for 'reparative readings.' In the course of the following analyses, I will be sketching out the ways textual production, in the course of about one and a half centuries, opened up these 'other spaces.' 


\section{Bluebeard's 'Closet:' Gothic Novels}

\section{Phallic Power: Horace Walpole's The Castle of Otranto}

In 1764, Horace Walpole published The Castle of Otranto, "his sole experiment in the novel form" (Clery 2009: 101), which would inaugurate the genre of Gothic fiction. While, in the first edition, the novel claimed to be a translation of a medieval Italian manuscript, Walpole, encouraged by the story's success, acknowledged his authorship in later editions, describing the novelty of his writing as "an attempt to blend the two kinds of romance, the ancient and the modern" (Walpole 2001: 9). Merging ideas of the fantastic and eighteenth century notions of 'realism,' Walpole, in "the ur-text in the Gothic canon" (Davison 2009: 38), lays the foundation for later works of fiction whose horror stems from this very combination. As Carol Davison emphasises, "Walpole's Otranto[...] marked a self-conscious aesthetic revolution against the realist novel" (Davison 2009: 39), making use of a supposed 'history' and its association with the supernatural in order to create a piece of art that addresses contemporary questions and cultural concerns in an innovative way. The novel, hence, is "fundamentally and ineradicably marked by its historic moment." (Davison 2009: 39) Walpole, most notably for our purpose, constructs a fictional world in which patriarchal (aristocratic) power based on lineage, and its architectural manifestation are already in a state of crisis. While his male characters are the ones in charge of domestic politics, and ultimately of women's bodies as well, the protagonist's 'phallic rage,' his paranoid and violent attempt to cling to his illegitimate position of power, is what finally leads to his decline. Bluebeard's phallus, Walpole seems to suggest, while uncontrolled and uncontained, will stab and crush at random - and finally crumble.

While the novel has not received much critical attention recently, and most of it, like Andrew Smith's reading in his introduction to Gothic literature, has focussed on "the theme of illegitimacy" (Smith 2013: 21), some work has been done concerning Otranto's preoccupation with issues of gendered space and sexuality. Gretchen Cohenour remarks how "[t]he castle becomes a space for the absolute male exercise of vicious and illegitimate desires; remote, dark, and gloomy, its 
malevolent setting mirrors that of the villain/owner" (Cohenour 2008: 75). Even more importantly for our purpose, Max Fincher situates the novel in the context of emerging discourses on same-sex 'sexualities' in the eighteenth century, and reclaims the Gothic for a creative engagement with masculinities: in the Gothic, "it is just as important to consider the place of masculinity as it is the place of femininity" (Fincher 2001: 229). Although I disagree with Fincher's emphasis on a biographical reading of Walpole's novel, he helpfully analyses the connection between Otranto's paranoid males and their violence against women, "how homophobia is structured upon a misogynistic viewpoint" (Fincher 2001: 233), in that fear of feminisation gets aligned with fear of 'unmanliness,' and a paranoid masculine disposition.

\section{Gothic Beginnings: The Weird Castle}

At the very beginning of the narrative, Walpole introduces the reader to the idea that the masculinities presented here are far from stable or powerful. Manfred is the current master of Otranto, but it is more than questionable whether he will be able to pass on his patriarchal power: his son Conrad, "a homely youth, sickly, and of no promising disposition" (Walpole 2001: 17), is his only male heir. Aware of his own illegitimate claim to his title, and threatened by "an ancient prophecy, which was said to have pronounced, That the castle and lordship of Otranto should pass from the present family, whenever the real owner should be grown too large to inhabit it" (Walpole 2001: 17), Manfred is eager to marry his son off to the heiress Isabella. Most of the plot will hinge on Manfred's attempts to save his power against all odds. His actions are triggered by his paranoid fear that the prophecy might come true. The dangerous knowledge the narrative is preoccupied with is simultaneously suppressed and already out in the open, making Manfred's 'closet' resemble the nineteenth century 'open secret' of homosexuality from the start: "Manfred's identity as the grandson of a usurper is simultaneously an open secret. It operates in a similar way in which the open secret of the condition of the homoerotic body does, through the collusion of silence and unspeakability." (Fincher 2001: 234) Walpole links this paranoid secret, which is always already on the brink of being spoken, with an array of physical manifestations of the phallus, and the threat of the potentially penetrable/penetrated male body.

His narrative is obsessed with questions of scale. Most objects that are central to the plot stand out due to their sheer massiveness. Conrad, the sickly only son, is "dashed to pieces, and almost buried under an enormous helmet, an hundred times more large than any casque ever made for human being, and shaded with a proportionable quantity of black feathers" (Walpole 2001: 18). This is only the first 
of several instances in which improbably large objects shape the course of events. Size, in fact, is tightly linked with masculinity in The Castle of Otranto. The giant helmet will remain central to the narrative, as a reminder of the weight of patriarchal expectation Conrad was too weak to live up to. It is no coincidence that he is killed just before his wedding, which would have required him to perform his duties as a husband, and provide the family with an heir. What remains instead is his dismembered body, and a bunch of oversized plumes, whose questionable phallic stability will feature as a physical sign of the family's precarious position. Manfred himself later explicates the connection between the physical setting and its function as a metaphor of power: "[Conrad] was a sickly puny child, and heaven has perhaps taken him away that I might not trust the honours of my house on so frail a foundation." (Walpole 2001: 23) This equation of space and metaphor will become one of the hallmarks of the Gothic, and turns cruelly literal here in Conrad's being crushed to death by the heavy secret from his father's past.

Besides physical manifestations of the power of the phallus, speech plays an important part in the politics of Walpole's novel. Power is not only controlled by those who can manage - or lost by those who get smashed by - the phallus, but also by those who can speak. Lack of voice gets associated with lack of power. In the face of the larger-than-life objects around them, Walpole's characters loose their ability to express themselves: "The horror of the spectacle, the ignorance of all around how this misfortune had happened, and above all, the tremendous phœnomenon before him, took away the prince's [i.e. Manfred's] speech." (Walpole 2001: 18) In fact, the ability to speak gets aligned with phallic masculinity, in that the giant helmet that crushes Conrad belongs to a statue of the castle's original master Alfonso the Good, who was poisoned by Manfred's ancestor. The dead man, then, effectively 'castrated' and silenced - he neither gets the chance to produce a legitimate male heir nor to speak the wrong he has been done - now silences Manfred, and fatally penetrates the body of the son Alfonso was denied. Notably, in an attempt to gain control over the situation, Manfred, uncannily reminded of his suppressed secret, and increasingly experiencing a corresponding "pathological terror" (Fincher 2001: 234), imprisons the young peasant Theodore, who later turns out to be Alfonso's grandchild, and the actual heir of Otranto, under the very helmet that killed his son (cf. Walpole 2001: 21). Without either of them knowing it, Manfred thus claims spatial authority over the man who will later replace him as master of the castle.

Manfred's position in his home is questioned once more shortly afterwards when he decides to marry Isabella, his dead son's fiancée, declaring his own wife Hippolita to be barren. Again, Walpole has him link phallic power and the power of speech in that, in the space of a few sentences, Manfred not only claims his 'right' to choose a woman who will provide him with an heir, but also performs 
the speech acts of divorcing his wife ("Hippolita is no longer my wife; I divorce her from this hour." [Walpole 2001: 24]), and eliminating her discursive existence ("[F]orget her from this moment, as I do. [...] I desired you once before, [...] not to name that woman." [Walpole 2001: 23; 24]). As before, the castle's spatiality 'reacts' to Manfred's hubris: a walking portrait of his grandfather "uttered a deep sigh and heaved its breast" (Walpole 2001: 24), contrasting Manfred's self-assertive speech with an utter lack of the same, and, at the very moment when Manfred is literally on the brink of violating a woman (Isabella), he sees the helmet's plumes again, "which rose to the height of the windows, waving backwards and forwards in a tempestuous manner, and accompanied with a hollow and rustling sound" (Walpole 2001: 24). These phalli are bloated, unstable, and empty. Manfred cannot control the phallic manifestations of patriarchal power within his castle. Spatially, this is reflected in the walking portrait's leading Manfred to a chamber, and then denying him access: "As [Manfred] would have entered the chamber, the door was clapped-to with violence by an invisible hand." (Walpole 2001: 25) Bluebeard has been shut out from his own closet.

Knowledge of, and control over domestic space are not in the house's master's hands. Isabella, escaping from Manfred's advances, turns out to know the castle's secret architecture better than the latter: "[S]he recollected a subterraneous passage which led from the vaults of the castle to the church of saint Nicholas." (Walpole 2001: 25) Not only does she manage to find her way through these passages, but she is even able to help Theodore, who is "unacquainted with the castle" (Walpole 2001: 27), escape the dungeons, because she inexplicably both knows that there is a trapdoor with "a lock, which opens with a spring, of which I know the secret" (Walpole 2001: 27), and, "taking out a key, she touched the spring, which starting aside discovered an iron ring” (Walpole 2001: 28). Otranto's secrets, it seems, have long been found out by this resourceful woman (cf. Cohenour 2008: 81). Simultaneously, the giant helmet begins to undo the castle's physical foundations: "One of the cheeks of the enchanted casque had forced its way through the pavement of the court, [...] and had broken through into the vault." (Walpole 2001: 29) Unsurprisingly, Manfred is disconcerted both by the two young people knowing more about his house's architecture than he does himself ("[T]hough hast not yet told me how though didst open the lock." [Walpole 2001: 30]), and by the fact that Theodore has escaped through its crumbling foundations.

Manfred increasingly loses control over the spatial management of his castle. While its secret passages are turned to use against him, its representative core is invaded by the same enormous apparition that has already blocked the court: two servants inform Manfred that "Satan himself I believe is in the great chamber next to the gallery. [...I]t is a giant, I believe; he is all clad in armour, for I saw his foot and part of his leg, and they are all as large as the helmet below in the court." 
(Walpole 2001: 32) The apparition - Alfonso from the prophecy - is too large to be grasped as a whole. It is both dismembered (only foot, only part of a leg) and powerful, the uncontainable secret from Manfred's past that threatens to burst open the castle's actual spaces, and destroy Manfred's claim to his position. Otranto becomes "a body steadily deteriorating from the secrets housed within" (Cohenour 2008: 76). Manfred himself more and more displays the kind of paranoia that will become typical of Gothic masculinities: "[H]e gave orders that every avenue to the castle should be strictly guarded, and charged his domestics on pain of their lives to suffer nobody to pass out." (Walpole 2001: 35) Locking Theodore "in a small chamber on the stairs" (Walpole 2001: 35), and making sure that he himself is not excluded from any information homosocially shared between Isabella and his wife and daughter (cf. Walpole 2001: 33-34), Manfred tries to contain spatially and epistemologically what goes on in his own house.

That secrecy is one of the novel's central concerns becomes even more obvious when Manfred's daughter Matilda is in her room with her maid Bianca. Matilda comments on her mother's keeping a secret from her: "[I]t is the mystery she observes, that inspires me with this - I know not what to call it. As she never acts from caprice, I am sure there is some fatal secret at bottom.” (Walpole 2001: 38) Hippolita, who always takes her husband's side despite his lack of compassion, makes herself Bluebeard's female helper in keeping a secret from her daughter to the advantage of Manfred, thereby blindly confirming patriarchal authority. Matilda, although admitting to the possibility of homosocial trust between herself and her servant ("I [Bianca] am sure, madam, you may trust me. - With my own little secrets, when I have any, I may, said Matilda." [Walpole 2001: 38]), accepts the authority of her parents' patriarchal voice: “[B]ut never with my mother's [secrets may I trust you]: a child ought to have no ears or eyes but as a parent directs." (Walpole 2001: 38) Accordingly, she criticises Theodore for wanting to pry into Manfred's secrets, although the young man only wants to help her: "Dost thou come hither to pry into the secrets of Manfred? Adieu. I have been mistaken in thee." (Walpole 2001: 41) Matilda's faith in patriarchal authority, and her own disinclination to have secrets, while making her seem "born to be a saint" (Walpole 2001: 38), also make her vulnerable, and, in the end, she dies at the hands of the very (F)father she has trusted.

A similar discourse evolves when Manfred, still looking for Isabella, meets Friar Jerome, a priest from the nearby monastery. While Jerome speaks with the authority invested in him by the church, Manfred claims authority in his own house; and while Jerome is eager to triangulate the power struggle through Hippolita, Manfred denies her a voice, and tries to establish a merely homosocial argument: "Father, [...] I pay due reverence to your holy profession; but I am sovereign here, and will allow no meddling priest to interfere in the affairs of my domestic. 
If you have aught to say, attend me to my chamber - I do not use to let my Wife be acquainted with the secret affairs of my state; they are not within a woman's providence." (Walpole 2001: 43)

Having succeeded in establishing homosocial privacy between Jerome and himself, Manfred shares his plan with the priest to divorce Hippolita and marry Isabella, and tries to convince him to become his accomplice. Underestimating Jerome's heterosocial interest in Isabella, Manfred believes in the priest's promise to help him: "The well-meaning priest suffered him to deceive himself, fully determined to traverse his views, instead of seconding them." (Walpole 2001: 47) Seeing women exclusively as bodies traded in the interest of lineage, Manfred can only perceive epistemological processes in a homosocial dimension. He cannot imagine the friar acting in the mere heterosocial (non-sexual) interest of the former's object of desire. In this very misogynistic move, however, also lies the danger Manfred is so eager to avoid: dissociating himself from women, he displays an exaggerated fear of effeminacy that becomes problematic in his exclusive focus on homosocial bonds. As Fincher observes, Walpole, in combining misogyny and homosocial excess in his paranoid male subject, hints at "an internalized homophobia in the fear of femininity lurking within the male subject" (Fincher 2001: 237). It is also, of course, crucial to see that, within the patriarchal system Walpole depicts, one that vitally depends on lineage, the female can never actually be negated: "Manfred has to rely on women to perpetuate his rule, and works to control them in any way he can. [...] Were there a way to perpetuate the patriarchy without women, [he] might be happy." (Heiland 2004: 13) Femininity, then, for Manfred, is a threat that, while it cannot be denied, has to be contained.

Walpole contrasts Manfred's paranoia with Theodore's striking lack thereof. Unlike Manfred, Theodore avoids being caught up in the political tangle around him by employing a rhetoric of honesty: "I answered to every question your highness put to me last night with the same veracity that I shall speak now. [...T]he truth I have told thee." (Walpole 2001: 48; 49) This apparent lack of secrecy disconcerts Manfred, who assumes masculinities to be built on homosocially traded information, and sees secrecy where there is none: "[T] ake care to answer with less equivocation than thou didst last night, or tortures shall wring the truth from thee. [...] Tell me, rash boy, who thou art, or the rack shall force thy secret from thee." (Walpole 2001: 48; 49) When Walpole finally confronts the reader with a hint towards the one big secret concerning Theodore - that he is the actual heir of Otranto - and Jerome discovers him to be his lost son, it is, once again, the strangely phallic giant plumes that foreshadow the effect the slowly emerging secret will have on Manfred's power: "[T] he sable plumes on the enchanted helmet, which still remained at the other end of the court, were tempestuously agitated, and nodded thrice, as if bowed by some invisible wearer." (Walpole 2001: 53) The 
secret, which is on the brink of being discovered, threatens the shaking, bending plumes' 'erection.

\section{Phallic Competition: The Traffic in Women}

In what follows in the novel, the phallic symbolism that infuses the narrative takes on almost comic dimensions. Manfred clearly associates the shaking plumes with a threat to his own person: his "heart misgave him when he beheld the plumage [...] shaken in concert with the sounding of the brazen trumpet" (Walpole 2001: 54). His actions and words get directly linked to the enormous black objects: "If I have offended - [the plumes were shaken with greater violence than before]." (Walpole 2001: 54) What ensues is a veritable phallic competition, because what the sound of the trumpet announces, and what coincides with the commotion in the plumes, is the arrival of Frederic, "the knight of the gigantic sabre" (Walpole 2001: 54). Walpole could have hardly filled the fictional space of Otranto with more oversized manifestations of his male characters' obsession with (and fear of loosing) their virility: Frederic's "penetration of Otranto with that sabre is a symbolic attempt to impregnate the castle body and breed out the usurper" (Cohenour 2008: 83). Manfred, challenged by the presence of the ominously potent knight, reacts according to by now established Gothic patterns of paranoid masculinity, and tries to keep control over his castle's spatiality. Shutting out Friar Jerome, and locking in Theodore, he takes recourse in performing a spectacle of spatial power for his opponent: "He then withdrew to the hall, and, seating himself in princely state, ordered the herald to be admitted to his presence." (Walpole 2001: 55) When a procession enters the hall, "[a]n hundred gentlemen bearing an enormous sword, and seeming to faint under the weight of it" (Walpole 2001: 58), and the giant enchanted plumes in the court get doubled in "a large plume of scarlet and black feathers" (Walpole 2001: 58) on the knight's helmet, Walpole constructs a dynamic that oscillates dangerously between homosocial rivalry and homoerotic desire: "Manfred's eyes were fixed on the gigantic sword. [...] He turned and beheld the plumes of the enchanted helmet agitated in the same extraordinary manner as before." (Walpole 2001: 58) Simultaneously fixing his male gaze on the larger-thanlife weapon that threatens to 'penetrate' his realm, and reminded of his fear of being unmanned, Manfred is suspended in a potentially compromising position of homosocial desire. When "the gigantic sword burst from the supporters, and, falling to the ground opposite to the helmet, remained immovable" (Walpole 2001: 59), the ambiguous physical proximity of the opposing phalli and their associated bearers is foregrounded even more prominently. 
It is striking that the "silent guests" (Walpole 2001: 59) refuse to employ the power of language, "answer[ing] only by signs" (Walpole 2001: 59), and not engaging in any discourse with Manfred. This refusal, counter-intuitively, denies Manfred recourse to the power of conviction, and he feels the need to justify himself and his title, receiving only occasional nods and signs of disagreement from the knights (cf. Walpole 2001: 60-61). Even though Manfred, as before with the friar, attempts to establish a space of homosocial interaction by taking his guests "into an inner chamber, shut[ting] the door" (Walpole 2001: 60), the silent strangers seem to have power over him who speaks incessantly for two and a half pages. The silent phallus/sabre lying in the hall is enough to rob Manfred of his authority.

Being thus shaken by the threat of penetration, Manfred increasingly loses control over the space of his castle. The friar bursts into the hall against his wish (cf. Walpole 2001: 63), and Matilda manages to free Theodore, transgressing the boundaries of gender and family she has adhered to so far: "Young man, $[\ldots]$ though filial duty and womanly modesty condemn the step I am taking, yet holy charity, surmounting all other ties, justifies this act." (Walpole 2001: 64) Ironically, Theodore, confronted with the prospect of Matilda's leading him to the church in which Isabella has already sought sanctuary, feels wounded in his masculine pride, and weakly proposes to engage in a 'proper' phallic battle: “[S]anctuaries are for helpless damsels, or for criminals. [...] Give me a sword, lady, and thy father shall learn that Theodore scorns an ignominious flight." (Walpole 2001: 65) Instead of confronting Manfred within the space of the castle, though, Theodore, equipped with a weapon, retreats to the liminal space of the forest, where "he sought the gloomiest shades, as best suited to the pleasing melancholy that reigned in his mind" (Walpole 2001: 67). This space, however, "haunted by evil spirits" (Walpole 2001: 67), does not afford him with an appropriate 'masculine' task, an opportunity to put his sword to homosocial use, and "to approve his valour" (Walpole 2001: 67). Instead, he is forced to "explore the secret recesses of this labyrinth" (Walpole 2001: 67), and, in extension, the secret recesses of his mind. Without proper homosocial rivalry and conflict, without an opportunity to cross swords (or phalli), Walpole suggests, his men become agitated and insecure. They define their masculinity purely against other men. Women, however, can serve as objects to be put to use in this 'chivalric' scenario. Luckily, Theodore meets Isabella in the woods, and immediately sees an opportunity to engage in sword-(phallus-)fighting in her name: "I will place thee out of the reach of his [Manfred's] daring. [...] I meant to conduct you into the most private cavity of these rocks; and then, at the hazard of my life, to guard their entrance against every living thing." (Walpole 2001: 68) Isabella, understandably, is concerned about the heterosexual implications of this very privacy: "[I]s it fitting that I should accompany you alone into these perplexed retreats?" (Walpole 2001: 68) Theodore, however, far from thinking of putting his 
penis to heterosexual use, is obsessed with putting his phallic sword to homosocial use - at the risk of death. The first person he badly wounds in his chivalric enthusiasm is Isabella's father Frederic, who, instead of being offended at the almost fatal penetration of his body, is reassured by Theodore's emphatic lack of heterosexual interest in his daughter: "This brave knight [...] will protect thy innocence." (Walpole 2001: 70)

In The Castle of Otranto, then, masculinity is stuck in a pathological state: neglecting heterosexual reproduction, it focuses on homosocial rivalry instead, reducing women to objects to be traded in the interest of male-to-male bonds: "Any exchange of sexual commodities, whether houses or women, between men becomes a contest that flows over into larger social control - the home/castle becomes a means of containing female bodies." (Cohenour 2008: 78) The men are, nevertheless, paranoid about playing down the implicit homoeroticism involved: if you are going to stick the phallus anywhere, it must be to kill, or at least to hurt. Only then can you acknowledge your homosocial desire for your fellow men.

In what follows, Walpole further constructs the phallus as a cult of homosocial knowledge. Frederic tells the others that he found the giant sabre having been taken into the confidence of a dying hermit. The old man had once had a vision of Saint Nicholas, who "revealed a secret" (Walpole 2001: 72) to him. This almost comically exaggerated construction of a mysterious lineage of homosocial secret sharing makes Frederic unwilling to share what he found out with the castle's women: "On the blade[...] were written the following lines - No; excuse me, madam [Hippolita...]: I respect your sex and rank, and would not be guilty of offending your ear with sounds injurious to aught that is dear to you." (Walpole 2001: 72) It is only reluctantly, "in a faltering and low voice" (Walpole 2001: 73), that Frederic finally does repeat that part of the ancient prophecy he found written on the sabre.

Although Walpole affords his female characters a moment of homosocial intimacy as well, they do not manage to take advantage of this moment, since Hippolita, excluded from the heterosexual economy of her marriage, is anxious to make herself part of a triangular dynamic again in helping cement the homosocial bond between Manfred and Frederic: she suggests to Manfred "the union of our rival houses" (Walpole 2001: 79) in asking Frederic to marry her daughter Matilda. Hence, although ostensibly propagating the homosocial bond between herself and the two younger women ("Isabella, you have so much tenderness for Matilda, and interest yourself so kindly in whatever affects our wretched house, that I can have no secrets with my child, which are not proper for you to hear." [Walpole 2001: 79]), she actually encourages the men's traffic in women, making herself, once again, Bluebeard's female helper, unconditionally accepting the power of patriarchy: "It is not ours to make elections for ourselves; heaven, our fathers, and our husbands, must decide for us." (Walpole 2001: 80) Hippolita, in fact, has been, up 
to this point, excluded from the story's female-homosocial secrets anyway: she is completely ignorant of the girls' shared love for Theodore. This rivalry, to an extent, mirrors and reverses the male-homosocial triangular structure described above, affording Isabella and Matilda a similar bonding moment over 'the traffic in a man:' "Each confessed to the other the impression that Theodore had made on her; and this confidence was followed by a struggle of generosity." (Walpole 2001: 78) Predictably, when Hippolita does find out the girls' secret, she is disinclined to take their side, merely reminding her daughter of her status as object to be traded in the interest of patriarchy: "Thy fate depends on thy father." (Walpole 2001: 82)

It is clear, then, that actual power - power over bodies, power over space, power over the phallus - lies with the men, and finds its most prominent embodiment in the giant statue of Alfonso, whose "size suggests the scale of masculine authority" (Smith 2013: 25). However, it is also remarkable that all the novel's (self-)destructive energies stem from its male characters' tendency to spill blood in their ambiguous attempts to negotiate homosocial bonds at the expense of women, and their paranoid need to distance themselves from any notion of weakness, 'unmanliness,' or homoeroticism. The novel's fourth chapter culminates in a scene of high camp when, in the church, a space of the highest patriarchal order, Manfred pronounces Matilda's engagement to Frederic. At his news, "three drops of blood fell from Alfonso's statue" (Walpole 2001: 85). This blood, on one level, denounces the violation of Matilda's virginal body. Since it is, however, Alfonso's nose that bleeds, it also reverberates with the thought of this man's violated body politic: his castle is still in the hands of the wrong man.

\section{Spatial Castration: The Fall of Otranto}

Although the power of violence clearly lies with Manfred, he compulsively needs to be in control of the knowledge that is circulated within the walls of Otranto. Suspecting (correctly) that there are secrets between Isabella and Matilda, which they keep from him, he tries to get the servant Bianca to tell him all she knows: "That damsel he knew was in the confidence of both the young ladies. [...Y] ou are in her [Matilda's] secrets." (Walpole 2001: 88) Manfred reminds her that her duties to him as patriarch outweigh her possible homosocial sympathies for the women: "[I]t is thy duty to conceal nothing from me." (Walpole 2001: 89) It does not become clear whether Bianca is naïve, and does not suspect any secret on Matilda's part, or whether she is clever enough to ostensibly comply with Manfred's claims to authority without giving her mistress away: "Nay, there is nothing can escape your highness, said Bianca." (Walpole 2001: 89) Manfred, in his paranoia, cannot be sure which is the case; he has to assume a secret anyway. 
This paranoia, at the centre of which lies the secret of Manfred's illegitimate claim to his title, is what Walpole represents spatially in the increasing reassembling of Alfonso's dismembered body, "a persistent presence that provokes anxiety for many of the characters, especially males" (Cohenour 2008: 79). When Manfred is just about to finally convince Frederic to marry Matilda, and give up any claim to Otranto, Matilda bursts into the room, reporting that she has seen "the hand! the giant! the hand!" (Walpole 2001: 90). The more Manfred tries to save his power, and keep his secret from bringing him down, the more manifest becomes Alfonso's giant presence in the castle. Frederic observes that "these are no trifles: the enormous sabre I was directed to in the wood; yon casque, its fellow" (Walpole 2001: 91). Bianca's being aware that the apparition must have something to do with the castle's dark secret ("Would I were out of this castle! My lady Matilda told me but yester-morning that her highness Hippolita knows something." [Walpole 2001: 91]) only makes Manfred even more eager to defend his good name and reputation: "Are my own domestics suborned to spread tales injurious to my honour?" (Walpole 2001: 91) Walpole associates the abstract threat to Manfred's name and power with the physical threat to his castle's architecture. Epistemological process and architectural disintegration go hand in hand, a phenomenon typical of later Gothic texts.

Into the last pages of the novel Walpole squeezes a firework of incidents that bring this dynamic to the boil. After a big feast in the great hall, at which Manfred stages his desired new connections in public, "plac[ing] the marquis next to Matilda, and seat[ing] himself between his wife and Isabella" (Walpole 2001: 92), Manfred wants to retire into homosocial privacy with Frederic, but is instead coerced into the heterosexual company of Isabella, a fact he is curiously unexcited about: "Manfred would have withdrawn with Frederic; but the latter, pleading weakness and want of repose, retired to his chamber, gallantly telling the prince, that his daughter should amuse his highness until himself could attend him." (Walpole 2001: 92-93) Homosocial desire, for Manfred, clearly outweighs heterosexual matchmaking. Similarly, when Frederic intrudes into Hippolita's apartment, looking for her in the 'closet' space of "her oratory" (Walpole 2001: 93) in order to convince her to agree to a divorce, what he finds is not the woman he is looking for, but the praying skeleton of the hermit who led him to the giant sabre: " $[\mathrm{H}]$ e saw a person kneeling before the altar. [...I]t seemed not a woman, but one in a long woollen weed, whose back was towards him." (Walpole 2001: 93) What is striking here is that the apparition is first unsexed ('not a woman'), and then recognised as the dead (fleshless, impotent) man who triggered one of the story's central phallic conflicts. The hermit warns Frederic "[t]o forget Matilda" (Walpole 2001: 94), oddly reminding him to abstain from the heterosexual economy none of the novel's men seem very talented at inscribing themselves into. Having de- 
nied Hippolita heterosocial confidence about what just happened to him ("I cannot speak." [Walpole 2001: 94]), Frederic rushes to his own apartment, only to run into a very ambiguously homoerotic encounter with Manfred: "At the door [...] he was accosted by Manfred, who, flushed by wine and love, had come to seek him, and to propose to waste some hours of the night in music and revelling." (Walpole 2001: 94) Walpole, predictably, denies the two men any homosocial/-erotic harmony in privacy. As before, they can only employ the phallus to gesture at their homosocial desire. Frederic, accordingly, "pushed [Manfred] rudely aside" (Walpole 2001: 94), and the latter can only go and look for phallic employment elsewhere. Having also been "driven from [Isabella] on his urging his passion with too little reserve" (Walpole 2001: 95), he rushes to Alfonso's tomb in the church, where, intending to murder Isabella (the phallus has to be stuck somewhere), he, instead, unintentionally kills his own daughter: "Manfred will never permit our [Theodore and Matilda's] union. - No, this shall prevent it! cried the tyrant, drawing his dagger, and plunging it over her shoulder into the bosom of the person that spoke - Ah me, I am slain! cried Matilda sinking." (Walpole 2001: 95) Failing to establish both a stable homosocial bond between himself and Frederic, and a heterosexual union with Isabella, Manfred 'rapes' his own daughter to fatal consequences. Instead of managing to propagate his line, then, Manfred, paranoid about getting it all right despite the prophecy, can only make use of the phallus in a destructive way. Patriarchy, as displayed in Otranto, in its paranoid attempt to cling to power, can only become violent. As George E. Haggerty puts it: "The normativity of paternal power is itself the perversion, and Walpole reminds us that the son and daughter must be sacrificed to the increasingly impotent and destructive sexual demands of the aging father." (Haggerty 2006: 25)

Walpole's women, in this disastrous scenario, do not manage to have a powerful voice of their own. Their only options are to be Bluebeard's helper and propagator of male-homosocial bonds (Hippolita), or to be the sexual object to be traded (and killed) in the interest of these bonds (Matilda). Matilda, using the sacrifice of her life as the only powerful weapon she has, tries to re-establish the heterosexual bond between her parents: "Matilda, seizing [Manfred's] hand and her mother's, locked them in her own, and then clasped them to her heart." (Walpole 2001: 97) The only way to tame Bluebeard-Manfred in his phallic rage is to bind him to a heterosexual promise via the ultimate taboo of having stabbed/raped/killed his own daughter, a taboo that takes on sacrificial character in its association with the space in which it is committed: "a child murdered in a consecrated place!" (Walpole 2001: 99). The patriarchal space of the church becomes, however, as Haggerty observes, complicit in Manfred's violence in that it fails to protect Matilda from the power of the (F)father she cannot distance herself from: "By placing this violence in the chapel of Otranto and suffusing the scene with the air of a religious 
sacrifice, Walpole makes a subtle connection between the heteronormativity of sexual violence and the patriarchal law of the father upon which Catholicism insists." (Haggerty 2006: 64) Matilda's parental fantasy of a heterosexual reunion must remain unfulfilled, and her sacrifice further foregrounds the unproductive rage of the men's phallic fight: "Matilda's pathetic victimization represents a kind of abjection that queers the fantasy by substituting a bloody corpse for the object of sexual desire. As Theodore and Manfred fight over the bloody dagger, Matilda lies there in defiance of their homosocial love-fest." (Haggerty 2006: 26)

Manfred being thus 'castrated,' having destroyed his family, the power vacuum he leaves is filled by Theodore, who now claims his right as "the sovereign of Otranto" (Walpole 2001: 97). It is remarkable that he immediately establishes his power on a basis of honesty, a trait he has been associated with from the start: "It was not my purpose the secret [of his right to the title] should have been divulged so soon; but fate presses onward to its work." (Walpole 2001: 97) Despite the obvious necessity to speak this secret in order for his claim to be acknowledged, Theodore's act of 'speaking out' nevertheless stands in stark and significant contrast to Manfred repeated acts of repression and silence. In Theodore, Walpole offers his readers the only male character who is not haunted by paranoid phallic confusions. "As an alternative to Manfred, Theodore represents a new kind of masculinity that unites the qualities of compassion, pliability and honour that are the antithesis to Manfred's aggressive double-dealing." (Fincher 2001: 238)

Although power has now shifted, the prophecy still gets fulfilled spatially: "A clap of thunder at that instant shook the castle to its foundations; the earth rocked, and the clank of more than mortal armour was heard behind. [...T]he walls [...] behind Manfred were thrown down with a mighty force, and the form of Alfonso, dilated to an immense magnitude, appeared in the centre of the ruins." (Walpole 2001: 98)

Manfred, additionally 'castrated spatially' by the destruction of the architectural representation of his power, can now speak the secret that has dethroned him: "Alfonso died by poison. A fictitious will declared Ricardo his heir." (Walpole 2001: 99) Manfred, however, is not the only character haunted by a secret from the past. Jerome, telling the story of how he came to be Theodore's father, admits that "the secret remained locked in my breast" (Walpole 2001: 100). Two things are significant here: Jerome, in his own paranoid fear of challenging Manfred, did not speak out against the latter's tyranny, and, hence, helped uphold the very paranoid patriarchal structures that finally killed Matilda. Secondly, however, the power now invested in Theodore has been inherited by the female line - Jerome married Alfonso's daughter. The newly established power in the ruins of Otranto is, then, indirectly based on the reproductive power of a women - not on the stagnant phallic rage of men; and Walpole's story ends with Manfred and Hippolita 
- Bluebeard and his female helper - "each [taking] on them the habit of religion in the neighbouring convents" (Walpole 2001: 100), hence permanently eliminating themselves from a heterosexual economy.

Walpole, in The Castle of Otranto, introduces the Gothic male as paranoid subject, preoccupied with dissociating his epistemological homosocial power from the threats of feminisation and homoeroticism. His "novel contains within it the seeds for later Gothic fiction by both men and women, especially in its focus on a paranoid, misogynistic male tyrant and concealed identities that are reversed and exposed" (Fincher 2001: 242). It is the first instance of a genre which, more than any other, begins to question norms as they are being established at the same historical moment, and delegitimises a reliance on Enlightenment ideals of the rational. The ensuing distrust of functional normative categories like modern patriarchal masculinities, and the ways that the Gothic is able to question and fragment them in its employment of fictional spatiality make The Castle of Otranto, in the words of Lee Morrissey, "a postmodern work" (Morrissey 1998: 87). It is, perhaps, the comic element in the Gothic, Walpole's employment of "humor, fakery, and melodrama," and early Gothic writers' "embracing surface rather than depth[, their] delight in excess" (Horner/Zlosnik 2012: 325), that make it easy to associate the genre with postmodern notions of camp, an attitude and aesthetics that devotes itself almost exclusively to the deconstruction of norms. While the humour of Walpole's writing gets lost in a lot of nineteenth century Gothic writing, Henry James will pick it up again, and become the master of a tongue-in-cheek 'queer Gothic rhetoric.'

\section{The Power of Absolute Spatial Access: Ann Radcliffe's The Mysteries OF UDOLPHO}

Ann Radcliffe's fourth novel is probably the most famous and most influential Gothic text, and has come to define the genre. Its archetypical plot of a female heroine who is carried off to a foreign country by a dark and villainous count, and locked away in his Gothic castle soon became a stock element of terror fiction. While feminist critics have extensively analysed the precarious spatial situation of Udolpho's heroine Emily, "unearth[ing] the 'anti-patriarchal', subversive psychodramas of [Radcliffe's] narratives" (Keane 2000: 18), even "rel[ying] disproportionately on [them] to inform feminist readings of Gothic space" (Ledoux 2011: 333), no one has so far had a closer look at how architecture, in this novel, not only always conceals a man's secret and serves as a representation of masculine power, but also already subverts these structures by contrasting specifically masculine spaces with female equivalents in which the power over knowledge has shifted 
to women. In the course of Radcliffe's story, men, stumbling over their paranoid handling of knowledge, are increasingly excluded from the domestic sphere.

Women, in Radcliffe's literary world, "move through landscape and [...] exceed the commonplace representational reduction of women to property, and indeed become proprietors" (Keane 2000: 19), while men become either chained to their 'closeted' secrets, or excluded from an increasingly subverted domestic space. The Mysteries of Udolpho, then, does not simply contrast "a safe, hierarchical, reasonable, loving world of the family with a chaotic, irrational, and perverse world of the isolated" (Durant 1982: 520), but, instead, subverts the structures of patriarchal masculinity while opening up possible spaces of female agency. In Radcliffe's fiction, Gothic architecture comes to stand for the structure of patriarchal society as a whole, an idea that later authors of the genre took up, for example William Godwin, who "found in Radcliffe's version of the gothic a model in which the psychology of a gothicized household could be used to represent abuses in society more generally" (Horrocks 2007: 33).

Three houses are central to the analysis of the novel's spatial semantics of secrecy: Udolpho itself, the Aubert's family home in La Vallée, and Chateau-le-Blanc. All three represent different nodes on a triangle of gendered power structures, and all three hide a secret. Udolpho, the novel's central Gothic site, serves as a spatial metaphor of patriarchal, male power. Its labyrinthine architecture both exposes Emily to the omnipresent threat of male violence, without granting her any privacy or protection, and symbolizes the paranoid structure of Count Montoni's dark secret from the past. Chateau-le-Blanc is its gendered mirror, the Gothic mansion that has come to defy male access, with the allegedly dead former mistress of the house having created a 'haunted' space that conceals a woman's secret, and expels any man that tries to penetrate its hidden spaces. La Valée stands between the two: it contains St. Aubert's secret, concealed in his closet; it also becomes, however, a symbol of a femininity that grows stronger, both in political and social terms, when Emily inherits it from her father, breaking both an exclusively patriarchal line of inheritance, and a psychological reading of the house as a representation of its owner's masculine power.

\section{Bluebeard's Castle: Udolpho}

The reader encounters Udolpho for the first time, through the eyes of Emily, as an edifice that evokes sublime terror and awe: it lies secluded in "a deep valley," surrounded by inaccessible mountains, "a gloomy and sublime object" that, from the start, seems to have a life and will of its own: "[I]t seemed to stand the sovereign of the scene, and to frown defiance on all, who dared to invade its solitary reign." 
(Radcliffe 2001: 215-16) The exterior architecture of this almost personified building, which Radcliffe abundantly equips with phallic towers, pointed arches, and pillars, displays Bluebeard's masculine power, an impression that is reinforced by Emily's foreboding that "she [is] going into her prison" (Radcliffe 2001: 217). This masculine power, however, is already crumbling and in a state of decay: the castle "wants a good deal of repairing. [...S] ome of the battlements have tumbled down[..., and] a part of the roof of the great hall has fallen in." (Radcliffe 2001: 218-19)

Within the walls of Bluebeard's castle, as Ellen Malenas Ledoux observes, lawful protection from society is out of reach: "The narrative implies that women are protected by a society willing to shame men who abuse women. Removed from the protection of that society within the impenetrable Udolpho, Emily and Madame Montoni become subject to the will of the individual patriarch." (Ledoux 2011: 337)

Radcliffe also suggests, however, that Udolpho is not an unusual space at all, but that, on the contrary, Montoni and Udolpho enact a masculinity that is representative of patriarchal society at large. As we shall see, in fact, La Valée and St. Aubert stand for the same principles of secretive masculinity as Udolpho; and both are challenged by the alternative architecture of Chateau-le-Blanc.

The space that Emily enters turns out to be precarious for her in many respects. The room she is led to is "in a remote part of the castle" (Radcliffe 2001: 223), and is called "the double chamber" (Radcliffe 2001: 220), a name that alludes to the room's peculiar spatial quality: one of its doors opens to a passageway of which Emily cannot know where it leads to. This door "had no bolts on the chamber side, though it had two on the other" (Radcliffe 2001: 224). Emily finds herself in a space that does not allow her to have any real privacy or control over who can access it. It holds secrets that are not her own, and constantly exposes her to potential (male) violence from without. This threat is made especially uncanny when the door is repeatedly locked and unlocked during the night without Emily noticing or knowing who the potential intruder might be: "She became seriously uneasy at the thought of sleeping again in a chamber, thus liable to intrusion." (Radcliffe 2001: 230) Emily's lack of power over space is repeated on several levels: Udolpho in its entirety, with its maze-like corridors and locked doors, simultaneously locks Emily in, and shuts her out from finding out more about what goes on behind the doors she cannot open. Similarly, Emily's room is both the only place that she can, to an extent, call her own, and a space that denies her the power to bar access to it to others. Within her room, Emily and Annette, one of the female servants, find "a great old chest[...; Annette] tried to lift the lid; but this was held by a lock, for which she had no key, and which, indeed, appeared, from its peculiar construction, to open with a spring" (Radcliffe 2001: 415). Emily is both within and without, 
kept in a space from which she can neither escape nor fully gain access to. She cannot penetrate the castle's secret, and remains powerless.

As in other Gothic novels, the terror Emily - and, by extension, the reader experiences is not so much based on actual violence against the female protagonist than on imagining the possibility of such violence. The means Radcliffe employs to this end are almost all closely related to her construction of Gothic spatiality. Emily cannot find any space of safety within the walls of Udolpho. Access to her room is not in her power, and outside her room, the corridors and dark rooms of the castle only serve to further trouble her. It is, however, not only Emily's helpless position as a prisoner in the castle, but also her own investigative activity that increase her terror. Her curiosity makes her the archetypical wife of Bluebeard: in search of the castle's secrets, the reader expects her to open the chamber containing the bodies of Bluebeard's wives at every turn, even though Radcliffe never goes so far as to actually depict a scene as gruesome as this. She prefers terror over horror:

"Terror and horror are so far opposite, that the first expands the soul, and awakens the faculties to a high degree of life; the other contracts, freezes, and nearly annihilates them. [...W] here lies the great difference between horror and terror, but in the uncertainty and obscurity, that accompany the first, respecting the dreaded evil?" (Radcliffe 1826: 149-150)

Radcliffe does, however, continually appeal to her reader's imagination for associations of violent potential. One of the best examples of this is the veiled 'picture.' Emily first hears of it from the castle's servants and is curious to see what is hidden behind the veil. The "faint degree of terror" (Radcliffe 2001: 236) she experiences when thinking of the picture only makes her even more willing to penetrate its secret. When Emily does unveil it, however, the narrative itself creates a new secret that will only be revealed at the very end of the story: "[W]ith a timid hand, [she] lifted the veil; but instantly let it fall - perceiving that what it had concealed was no picture, and, before she could leave the chamber, she dropped senseless on the floor." (Radcliffe 2001: 236) Towards the end of the novel, the reader learns what is actually hidden behind the black veil: "a human figure of ghastly paleness[...;] the face appeared partly decayed and disfigured by worms" (Radcliffe 2001: 622). The figure is only, however, "formed of wax" (Radcliffe 2001: 622), a memento mori created by the late Marquis of Udolpho. The point is that, even though, in the end, we learn that what Emily sees is actually harmless and does not have anything to do with Montoni's crimes, it does work as an uncanny image of the danger Emily might be in. She is genuinely horrified at the sight of what she finds, and the reader shares her reaction. Radcliffe, however, denies the reader knowledge of what Emi- 
ly actually sees until the very end of the novel, thereby creating a further effect of terror on the reader that helps understand the female protagonist's terror, a terror that is created in the readers' own minds, because we do not know what Emily has seen; we can only guess. The narrative evokes terror because it denies us access to a secret which we conceive of as a threat.

The difference between terror and horror has a lot to do with knowledge and ignorance. Horror often implies immediate physical danger, but this danger can usually be grasped and faced. A novelist of terror, however, leaves it to the readers' imagination to guess what might be in store for the characters. The Mysteries of Udolpho achieves terror on two levels: most of Emily's fears are actually projections of her own mind, triggered by real fears for her physical safety that never, however, lead to scenes of actual horror. The reader shares this terror with Emily. Additionally, however, Radcliffe achieves terror on a narrative level: by withholding essential information about the scenes of alleged horror from the reader, she creates another layer of terror, because the reader's imagination will fill these gaps with images of horror that the cultural and narrative context (physical violence against women) suggests. The reader becomes both Bluebeard's wife and the 'paranoid reader,' and experiences the power of secrecy, and the feeling of helplessness that a lack access to knowledge can create.

Even though Emily does not die, this scene suggests that, in the world of Udolpho, a woman who tries to penetrate the secrets of the castle's master will meet as similarly violent an end as Bluebeard's wives; and, indeed, after this incident, Emily is even more aware "how wholly she was in the power of Montoni" (Radcliffe 2001: 238). Again, the mysterious locking and unlocking of doors adds to this power when Emily finds that, shortly after her own visit to the room containing the black veil, another servant tried to enter it, and found the door locked: "Emily now began to fear, that her visit to the chamber had been observed." (Radcliffe 2001: 242) It almost seems as if Montoni's power were exercised through the castle itself, without its master's ever having to visibly intervene. Keeping its own secrets concealed, Udolpho takes on a panoptical quality for Emily. She does not have any control over this space, can be locked in and out at will, and is not afforded any privacy. Even her mind, a modern individual's last refuge, is increasingly intruded by the terror evoked by her spatial situation. As in other Gothic fiction, the space of the house stands for and mirrors the space of the mind.

The sexual threat that is implicit in a lot of the narrative's terror never becomes explicit, but the danger Emily is in does not stop at the level of the imagination either: "The door of the stair-case was, perhaps, a subject of more reasonable alarm" (Radcliffe 2001: 246), and, indeed, one night Emily's fears come true: Count Morano enters her bedroom through the mysterious door, and "advance[s] towards the bed" (Radcliffe 2001: 247) with a sword in his hand. The narrative is ambiguous 
in its description of this scene's terror. The situation certainly bears a lot of erotic potential, and - as at other points in the novel - Emily seems to have an almost masochistic longing for the sexual danger she is in, "trembling between joy and fear" (Radcliffe 2001: 248) (cf. Abdulatief 1994). All this, however, does not alter the fact that power here is unambiguously in the hands of masculinity, both on a spatial (the accessible room) and immediately physical (the man carries a sword) level. In Udolpho, all characters play the game exactly as normative modes of gender require. Masculinity is powerful and active, femininity powerless and passive: "Unable to reply, and almost to think, [Emily] threw herself into a chair, pale and breathless." (Radcliffe 2001: 249) Emily, both realising that she cannot escape the power of men even if she were to go with Morano, and knowing no other way to act, is willing to stay in the castle and in the realm of Montoni's power. Morano, equally acting according to cliché codes of phallic masculine behaviour, would risk an armed conflict with his rival Montoni for the sake of 'honour:' 'Let him dare to face once more the man he has so courageously injured; [...] let him come and receive my sword in his heart." (Radcliffe 2001: 250) The woman in this triangle is reduced to an object to be traded in the name of masculine 'honour' and homosocial rivalry: Morano would take Emily with him by force, he "will not leave [her] to be sold by Montoni" (Radcliffe 2001: 251). He even becomes pathetically jealous when Emily will not come with him: "[Y]ou - you - love Montoni! [...H] e shall not live to triumph over me!” (Radcliffe 2001: 251) Similarly, Montoni, having wounded Morano, insists on blaming Emily for the incident, and thinks of her only in terms of a possession that a male rival might steal: "Count Morano [...] you favour, it seems, since you find I have dismissed him.” (Radcliffe 2001: 255) In Udolpho, Emily is completely powerless. In this world of male-homosocial power relations, her only value lies in the potential creation of a financial bond through an advantageous marriage that will further the interests of the men involved.

Emily's aunt, Madame Montoni, is in a similarly compromising position. Her husband's only aim is for her to sign off her estates to him, and Montoni, locking her up, and making use of the spatiality of his uncanny castle, tries to force her to do as he wishes: “'Am I blocked up here to die?' 'That may possibly happen, [...] unless you yield to my demand: for, come what may, you shall not quit the castle till then. [...] You shall be removed this night [...] to the east turret: there, perhaps, you may understand the danger of offending a man, who has an unlimited power over you." (Radcliffe 2001: 287)

Here, the threat to the women's safety gains a rare physical actuality: both Emily and her aunt are aware that the older woman might not survive being locked up alone in a remote and cold part of the castle for long. Again, the scene is reminiscent of the Bluebeard tale, in which the disobedient wives are brutally killed, and the bodies locked away in a remote room of the castle. The women know that 
they live with the constant threat of being fatally absorbed into the castle's secret architecture, without anyone ever wondering about their whereabouts. It also, however, becomes obvious in this scene that Emily and her aunt are not completely powerless: they legally possess the novel's important land and estates. If Madame Montoni does not give her estates up to Montoni, her niece will inherit them: "Do you understand, that these estates will descend to you at my death, if I persist in a refusal?" (Radcliffe 2001: 290) This is not immediate, physical power, but it is a form of abstract power that demonstrates how dependent on women the men in Radcillfe's world actually are. Madame Montoni, until the end, refuses to give up her estates to Montoni, even though her confinement does finally cause her death. Emily, however, repeatedly expresses "her willingness to resign all claim to those estates" (Radcliffe 2001: 351). She does not see that both her aunt's and her own only source of relative power (and temporary guarantee to be spared any real physical harm) is the fact that Montoni's legal access to the real space of Madame Montoni's estate lies beyond his reach. Only after her aunt's death does Emily realise that owning these estates provides her both with a protection from immediate physical danger, and with a potential future of independent female agency and a life of her own: "[T]he property, which she would willingly have resigned to secure the peace of her aunt, she resolved, that no common sufferings of her own should ever compel her to give to Montoni." (Radcliffe 2001: 358) Montoni, fully aware that he has no legal claim on the estates, can only resort to another threat of physical violence: "[Y]ou have dared to question my right, - now dare to question my power. I have a punishment which you think not of; it is terrible! This night - this very night" (Radcliffe 2001: 372). Masculinity, as represented in Montoni, articulates power through spatial violence, and the (finally impotent) threat of real, physical violence. In the end, Emily yields to this power, and gives up the estates and her only source of potential power - to buy her own freedom, but Montoni has deceived her, and she stays a prisoner in Udolpho.

Emily's chamber remains a space of unease for both her and her female servant and confidant Annette. One night, Emily is alarmed both by the sound of someone outside the door leading to the corridor and of footsteps "ascending the private staircase" (Radcliffe 2001: 283). The effect of feminine terror is doubled: Emily is caught between potential (male) threats from two sides of her room; and Annette seeks refuge in the female company of this never-safe space from "a tall figure gliding along [...in the corridor] into the room, that is always shut up, and nobody has the key of it but the Signor" (Radcliffe 2001: 284). Again, the spatial situation of locked and unlocked doors that bar or admit access emphasises the arbitrary potential of violence the women are exposed to in Udolpho. Emily's fear that the room in question might be the one in which she found the mysterious veil admits the reader to construct a mental map of a triangle of closely related rooms in im- 
mediate proximity, both spatially and metaphorically: Emily's own room, which constantly seems to both protect and threaten her; the room with the black veil; and another room close by, which contains the portrait of the former mistress of Udolpho, Lady Laurentini. Taking into account the hindsight knowledge of Emily's fantasy that the veil hides the rotting corpse of this lady, we can read this triangle of rooms as the spatial nucleus of potentially subversive - albeit always precarious - feminine power.

Challenging mainstream feminist interpretations of Gothic space as symbolising only female imprisonment, Ellen Malenas Ledoux shows that women, in Radcliffe's novel, are not simply victims of male violence, but can also, "through responding actively to threatening situations, model a manly sense of agency[..., and that] authors use the allegorical potential of Gothic space to engage in a more complex exploration of domestic politics than a univocal critique of patriarchy" (Ledoux 2011: 331-32). Although Udolpho seems to be a predominantly masculine space, the reader soon learns that Montoni's possession of it actually goes back to his inheriting it from a woman. Her sudden disappearance, at the same time, constitutes the castle's (and Montoni's) mysterious secret from the past. This woman, however, is still an important, albeit marginalised, presence in Udolpho. Annette, showing Emily a portrait of the castle's former mistress, comments on this: "[T]he Signor would do well to hang [the picture] in a better place, than this old chamber. Now, in my mind, he ought to place the picture of a lady, who gave him all these riches, in the handsomest room in the castle." (Radcliffe 2001: 263) Montoni himself admits to his friends that he inherited the castle "by the female line," Lady Laurentini, the former owner of castle Udolpho, having allegedly "put a period to her own life" under "some singular and mysterious circumstances" (Radcliffe 2001: 273). Montoni deliberately employs a rhetoric of mystery and ignorance - both strategies closely related to denial - instead of not talking about the incident at all. Similar to Falkland in Caleb Williams, Montoni seems torn between protecting his secret, and sharing it with others. According to his account, Lady Laurentini retired to her room one night in a fit of "frantic madness," and "[f]rom that hour, she was seen no more" (Radcliffe 2001: 274). It is as though the castle itself had made her disappear, a fact suspicious to both Montoni's friends and the reader. In fact, as the reader learns in the end, Laurentini did give up her castle in a fit of guilty despair; Montoni, however, is not the legal heir, but Emily, who inherits the castle from Laurentini.

The literal power to imprison women is not restricted to the novel's villainous characters. Instead, Radcliffe also gives an example of how being confined to a room by a man can be a source of protection for a woman. Annette tells Emily that her friend and fellow servant Ludovico, in a moment of imminent danger to her safety, "locked [her] up, as he has often done before, in a room in the middle of 
the castle" (Radcliffe 2001: 408). Annette deliberately puts herself in the spatial power of a man she deems trustworthy. Emily realises that she has hardly any other option herself: running away from the castle would make her subject to immediate physical dangers, and in the castle, she has to give herself up to the 'protective' power of either of two men; and since Montoni's rhetoric of chivalric protection is an obvious trap ("“You know the terms of my protection [...]' [...H] wo would only conditionally protect her, while she remained a prisoner in the castle." [Radcliffe 2001: 410]), she has no other choice than to opt for another potential imprisonment, and "entreat[s] [Ludovico's] protection" (Radcliffe 2001: 409), fearing that she will again be traded to be married to Signor Verezzi.

Radcliffe repeatedly employs a language of secrecy and curiosity in her depiction of Udolpho and Count Montoni. These discourses, in fact, are present in over-abundance, based both on an actual, and on an imagined concealment of knowledge. The effect of this is a foregrounding of what a rhetoric of secrecy can do, independent of what the concealed knowledge actually is, or whether the secret is, in fact, empty. What makes the character of Montoni so threateningly powerful to Emily and to the reader is, most of all, his capacity to mystify. Until the end of the novel, neither Emily nor the reader can be absolutely sure what his motives are, or what actually lies buried in his secret past. His behaviour within the space of the castle both fascinates and scares Emily: "[H]er astonishment only began, which was now roused by the mysterious secrecy of Montoni's manner, and by the discovery of a person, whom he thus visited at midnight, in an apartment, which had long been shut up, and of which such extraordinary reports were circulated." (Radcliffe 2001: 291)

Both the castle itself and its master are full of secrets and seeming arbitrariness for Emily. This kind of secretive masculinity, paired with Montoni's violent demeanour, have an ambiguous effect on the novel's female protagonist. Emily constantly fears for her own and her aunt's safety, but also seems excited and fascinated by Montoni-Bluebeard. When her aunt advises Emily to try and escape from the castle, she "accord[s] with her in the wish, but differ[s] from her, as to the probability of its completion" (Radcliffe 2001: 292). It seems that Emily - at least subconsciously - feels a certain desire to stay at Udolpho, and in its master's power. We can also observe this almost masochistic tendency in a later scene in which Emily, walking through the castle at night, comes across a chamber containing what she concludes to be "instruments of torture" (Radcliffe 2001: 329). Being about to faint, she "seat[s] herself, unconsciously, in the iron chair itself" (Radcliffe 2001: 329). In her morbid curiosity to further penetrate the castle's spaces, Emily actively puts herself in the position of victim. In the same room, she finds a curtain concealing a remote part of it. This curtain works for the narrative in very much the same way as the black veil hiding the 'picture.' Emily's own curiosity has 
her actively reveal the secret that lies beyond: "[S]he wished, yet dreaded, to lift [the curtain], and to discover what it veiled.” (Radcliffe 2001: 329) Again, what she unveils is a sight of abject horror:

"Beyond, appeared a corpse, stretched on a kind of low couch, which was crimsoned with human blood, as was the floor beneath. The features, deformed by death, were ghastly and horrible, and more than one livid wound appeared in the face. Emily, bending over the body, gazed, for a moment, with an eager, frenzied eye; but, in the next, the lamp dropped from her hand, and she fell senseless at the foot of the couch." (Radcliffe 2001: 329/30)

Of course, as the reader later learns, what Emily has seen is not a corpse, but a wounded soldier. For the moment, however, the effect is one of real horror. Two things are important to note here: it is Emily's own action that reveals to her what lies in the secret space beyond the curtain; and she is as fascinated as she is horrified by the sight of blood, wounds, and violent deformity. Once again, it is helpful for our purpose to read this scene through the lens of the Bluebeard tale. Emily's mind is full of real and imagined fear for her own physical integrity. It is her own curiosity that drives her to further penetrate Udolpho's secrets; but at every instant, she expects to find Bluebeard's secret chamber, in which he keeps the physical evidence of his punishment of any woman who tries to penetrate his secret: the mangled corpses of his former wives. Bluebeard's secret chamber works for Radcliffe like a cultural blueprint of female abject horror: for women in these texts to want to know too much means to risk physical violence, or even elimination. Even though this psychological threat never becomes real in its physicality for Emily, it is there, for her and for the reader. Montoni's (and Udolpho's) masculinity defines itself through the threat of physical violence against women. On the other hand, of course, Montoni is in a problematic position himself: his actually killing Emily would not get him what he wants (money and her aunt's estates), and, in the end, his power, which is built on a lie (he is not the legitimate heir of Udolpho), collapses.

\section{A Female Bluebeard's Castle: Chateau-le-Blanc}

Although Udolpho's Gothic architecture dominates the greater part of Radcliffe's novel, its representation of emphatically masculine spatial power is mirrored by another, smaller chateau that provides an important setting for Emily's adventure: Chateau-le-Blanc. The reader becomes immediately aware that here it is not clear at all who has power and who does not. The chateau's master, the Marquis de Villeroi, has recently died, and has left the house to his friend, the Count de Villefort, 
who never sets foot in it. Even before his death, the Marquis had taken "a dislike to the place, and has not been there for many years," even though it had earlier been his "favourite residence" (Radcliffe 2001: 68). There must have been something about the house that drove its master from it. Currently, "the old housekeeper, and her husband the steward, have the care of it" (Radcliffe 2001: 68); and it soon becomes clear that the female housekeeper is, literally, the keeper of the keys to the chateau's secret rooms.

Chateau-le-Blanc, as a Gothic space, is just as mysterious as Udolpho, but the gendered connotations are reversed. It is the former residence of the deceased Marchioness de Villeroi, who, as we find out in the course of the story, forms part of the secret past of both Emily's father and Lady Laurentini, the late mistress of Udolpho. It is not surprising, therefore, that her own house has a reputation for being haunted too: "[N]obody likes to go near that chateau after dusk." (Radcliffe 2001: 84) The house, though it has not been inhabited for years, has the power to keep people away and in fear of its secrets. La Voisin, a resident of a nearby village, denies Emily any information about the house: "[I]t is not for me to lay open the domestic secrets of my lord." (Radcliffe 2001: 84) In hindsight, this sentence seems almost ironic, because we soon find out that the secrets that are concealed in the chateau are not the 'lord's' secrets at all: he does not know about its secret rooms and what they hide. Power over space and knowledge from the past is firmly in the hands of the house's dead mistress and her female servant.

The story of Blanche, the Count de Villefort's daughter, doubles Emily's role as Gothic heroine on a micro level: she is "not yet eighteen, had been hitherto confined to the convent, where she had been placed immediately on her father's second marriage" (Radcliffe 2001: 438). She is an inexperienced, young female, placed into a confinement that keeps her ignorant and sexually innocent. Strikingly, in the world of Chateau-le-Blanc, it is not primarily male agency that puts Blanche in the hands of the Catholic Church, one of the pillars of patriarchal control of knowledge. Instead, her stepmother's "dread of superior beauty [...] urged her to employ every art, that might prevail on the Count to prolong the period of Blanche's seclusion" (Radcliffe 2001: 438). The current Countess de Villeroi, however, only exerts power through the male institutions she has indirect access to. Only with the almost simultaneous arrival of Blanche (on "the day, which was to emancipate her from the severities of a cloister" [Radcliffe 2001: 439]) and Emily at Chateaule-Blanc, are the secrets hidden in the house uncovered, and take on a particularly gendered dimension.

When the Count's family, for the first time since he has inherited the chateau, approach the building, the place impresses them as unfriendly and unwelcoming: the road to the house is "overgrown with luxuriant vegetation;" the chateau is "a dismal place," a "barbarous spot" (Radcliffe 2001: 441). Architecturally, the build- 
ing is a pastiche of different styles, "not entirely built in the gothic style, but [... with] additions of a more modern date" (Radcliffe 2001: 441). Chateau-le-Blanc is presented to the reader as a Gothic 'haunted mansion,' very much reminiscent of the fairy-tale architecture of Sleeping Beauty's castle, overgrown and forgotten, which nevertheless defies the uniform terror of Udolpho's architecture. It is a place that has been transformed by its mistress into something that goes beyond the threatening power structure of a dark Gothic castle into a domestic space that Radcliffe deliberately constructs such that it connotes feminine agency.

At first, however, the chateau presents itself to its visitors as a place not that different from Montoni's Udolpho. The hall, the nucleus of masculine domestic power and grandeur, is "large and gloomy," and "entirely gothic" (Radcliffe 2001: 441 ), and the whole place "would require considerable repairs and some alterations, before it would be perfectly comfortable, as a place of residence" (Radcliffe 2001: 442/43). The house, however, soon reveals its more peculiar aspects: Blanche, exploring its unknown spatiality like a true Gothic heroine, discovers rooms that deny the chateau's architecture any homogeneity as a site of Gothic terror. Blanche finds a saloon that "had been either suffered to fall into decay, or had never been properly finished," with windows that afford "a very lovely prospect" (Radcliffe 2001: 443). Behind another dark passage, she comes to "a hall, but one totally different from that she had formerly seen, [...an] apartment [...] of very light and airy architecture [...with] arches built in the Moorish style" (Radcliffe 2001: 444). Chateau-le-Blanc is a place both in flux and frozen, a conglomerate of styles and tastes, incorporating the new and the foreign, bearing the potential to be something it does not seem to be at first glance. All recent changes and developments in the chateau's architecture were initiated before the late Marchioness de Villeroi's death, and now lie dormant under layers of dust, waiting to be disturbed. It is at this moment, when she is alone in the strange but stimulating atmosphere of the 'other' hall, that Blanche fully realises her newly-gained freedom. Standing at one of the hall's windows, in a liminal space suspended between the old and the new, nature and architecture, foreign and familiar, she experiences a truly Romantic epiphany:

"And have I lived in this glorious world so long, [...] and never till now beheld such a prospect - never experienced these delights! Every peasant girl, on my father's domain, has viewed from her infancy the face of nature; has ranged, at liberty, her romantic wilds, while I have been shut in a cloister from the view of these beautiful appearances, which were designed to enchant all eyes, and awaken all hearts." (Radcliffe 2001: 444)

In bringing Blanche to Chateau-le-Blanc (it seems fitting that the 'white' girl should finally enter the 'white castle'), Radcliffe juxtaposes two chains of associa- 
tions: Blanche, the feminine, Chateau-le-Blanc, the Marchioness, the new, nature, freedom on the one hand; and the cloister, the masculine, the Marquis, the old, estrangement from nature, imprisonment on the other. As a narrative strategy, this is an extremely clever move: within a few pages of a subplot, Radcliffe manages to associate the revolutionary potential of Romanticism with feminine agency. Chateau-le-Blanc, as a masculine space, changed, and now seemingly haunted by its former mistress, helps Blanche - and the (female) reader - see how women can define for themselves a space of their own.

Blanche becomes the prying female, but instead of uncovering a dangerous masculine secret, she helps reveal the chateau's powerful feminine secret, which, it seems, wants to be found out by the young women. Blanche continues to explore the chateau's rooms, and begins to penetrate its more remote and secret spaces and maze-like architecture. Passing thorough several corridors, up "a back staircase," and through "a door in the wall," she arrives "in a small square room," and gets lost "in a dusky passage" (Radcliffe 2001: 451). She is found by the housekeeper Dorothée, the only character who finds her way easily through all the rooms and corridors in the chateau. Dorothée informs Blanche that a door the latter has found locked "open[s] to a suit of rooms, which had not been entered during many years" (Radcliffe 2001: 452). This is where the chateau's secret lies: the countess died in one of the rooms behind the door, and, since then, no one has entered them. They are the house's 'closet', albeit not a masculine one. What lies behind these doors, protected by the female keeper of the keys, is the most private part of the house's late mistress' domestic sphere. Naturally, just as Emily's curiosity makes her explore what lies behind curtains and veils in Udolpho, and just as Bluebeard's wife opens the door to the forbidden room, Blanche, intrigued by the knowledge that might lie behind the door Dorothée asks her to leave shut, now wants "to see the suite of rooms beyond" (Radcliffe 2001: 462).

The reader soon learns that the secret of Chateau-le-Blanc is closely connected to Emily's own history and her father's past. It turns out that Emily bears a striking resemblance to the late Marchioness, and Dorothée recognises her former mistress' face in a medallion that Emily has found in her father's own closet. Becoming aware that there seems to exist some connection between herself and the Marchioness, Emily feels "a thrilling curiosity to see the chamber, in which the Marchioness had died" (Radcliffe 2001: 498), and convinces Dorothée to enter the forbidden rooms with her. Radcliffe here constructs a female triangle that turns out to have the potential to uncover all the secrets the men in the novel (Montoni, St. Aubert) have tried to conceal: Emily (and, in extension, Blanche) is the agent of female curiosity who instigates the opening of the Marchioness' 'closet;' the dead Marchioness herself - and her ongoing, uncanny presence in the chateau - is the key to solving all the story's mysteries; and Dorothée literally holds "the keys of 
that suite of rooms, which had been particularly appropriated to the late Marchioness" (Radcliffe 2001: 499).

In what follows, Radcliffe constructs a scene of female-homosocial intimacy that problematises the position of femininity within the novel's structures of knowledge and power. Although Dorothée is the female guardian of the Marchioness' apartment, she is unable to unlock the door. Instead, Emily succeeds in turning the key. This becomes crucial in hindsight, because Emily, in fact, now enters her own aunt's apartment. Together with Dorothée, who goes on to "unlock [...] the door that lead[s] into the late Marchioness' apartment" (Radcliffe 2001: 501), Emily penetrates these rooms increasingly further, rooms that still bear witness to what their dead inhabitant had made of them, "rich in the remains of faded magnificence" (Radcliffe 2001: 500). The Marchioness still seems present, with the curtains around her bed "remaining, apparently, as they had been left twenty years before;" Dorothée even imagines to "see my lady stretched upon" it (Radcliffe 2001: 501/2).

The secret that lies hidden in these rooms is kept in the most private part of the Marchioness' apartment, literally in her closet. Here, Emily finds a picture that resembles the one she has found with her father's belongings, and that makes Dorothée again remark on Emily's likeness to her former mistress. The Marchioness' ghostly presence is highlighted by "many memorials" that the two women find in her closet, amongst them "a long black veil, which, as Emily took it up to examine, she perceived was dropping to pieces with age" (Radcliffe 2001: 502). This veil, on a symbolic level, is clearly connected with the novel's other veils and curtains. In all other instances, they posit a line that, if crossed, will expose the female heroine to moments of (imagined) horror, and the reader to experiences of (real) terror. In this scene, however, the uncanny movement of unveiling is broken: This veil, once covering a woman's head, is reduced to a piece of cloth that does not conceal anything, but only serves as a medium of communication from aunt to niece. It has been deliberately left where Emily finds it: “[M]y lady's hand laid it there; it has never been moved since!" (Radcliffe 2001: 502) The veil also enables Dorothée to take Emily close to an act of identification with the dead Marchioness: throwing the veil over Emily, she observes "how like you would look to my dear mistress in that veil" (Radcliffe 2001: 503). On the level of plot, Radcliffe further foreshadows the kinship between Emily and the Marchioness. The veil, however, has a semantic function that goes beyond this: Emily's ultimate rejection of an immediate identification (she "disengaged herself from the veil" [Radcliffe 2001: 503]) emphasises that Emily, at this point, will not accept inheriting a female role that connotes gendered spatial constraints. The veil, here, can be read as a symbol of any form of female subservience - a nun's headgear, a woman in mourning, a 
woman hiding or being hidden from the public gaze - a theme Henry James will reverse in Juliana's powerful gaze from underneath her veil in The Aspern Papers.

Emily's arrival triggers a change in this secret female space, which seems to come alive in her presence. Neither the Marquis nor the chateau's current male owner have ever entered it after the Marchioness' death. The dead woman's presence, however, becomes uncannily palpable to Emily, both when she "survey[s] the closet, where every object, on which her eye fixe[s], seem[s] to speak of the Marchioness" (Radcliffe 2001: 503), and when she believes she sees the dead woman's face on the bed she died in. Of course, as in similar instances, Radcliffe reveals later that this ghostly appearance is nothing but a real face, albeit not that of the Marchioness; for the moment, however, the illusion has the effect of bringing Emily into almost physical contact with the dead Marchioness in her own and the readers' imagination. This 'closet' is constructed such that it helps Emily realise her secret past; and her penetration of this secret female space will help disclose the male characters' secrets.

The apartment presents itself in a very different light when the novel's men enter it. Radcliffe draws the picture of an almost comic male conspiracy against the alleged ghost hiding in the Marchioness' rooms. Ludovico meets the Count in the latter's own closet, where he receives a sword which "has seen service in mortal quarrels" (Radcliffe 2001: 534), and is now to serve Ludovico in his fight against the 'ghost.' The Count's deliberately mocking tone in this farce of phallic masculine courage does nor diminish its effect on the reader, because, although the characters do not take the threat seriously, they will actually experience uncanny moments in the 'haunted' rooms.

Radcliffe presents masculinity as not being in control of spatial access. In order to get into the Marchioness' apartment, it is again Dorothée who unlocks the door, because "Ludiovico, unaccustomed to the lock, could not turn it" (Radcliffe 2001: 514). The Count, who has not set foot in the apartment since the Marchinoess' death, acknowledges how much this space's former grandeur relied on its mistress: "[H]ow the room is changed since I last saw it! I was a young man, then, and the Marchioness was alive and in her bloom." (Radcliffe 2001: 516) The apartment seems to have faded and died with its female inhabitant, and has taken on a "funeral appearance" (Radcliffe 2001: 516). Ludovico, who is asked to stay in the apartment over night, can only summon enough strength when his (masculine) courage is questioned: "[P]ride, and something like fear, seemed struggling in his breast; pride, however, was victorious." (Radcliffe 2001: 516) Ludovico penetrates the apartment's most private recesses, and also enters the Marchioness' closet, finding her portrait. Unlike Emily, however, he cannot make sense of what he sees there, not gaining any additional, albeit fragmentary, knowledge the way Emily and Dorothée do. 
The "Provençal Tale" that Radcliffe includes at this point in her narrative mirrors the loss of control over space and knowledge that her male characters experience in Chateau-le-Blanc. The Baron, in this tale, is master of a castle that represents his powerful position: He gives a feast "in the great hall [...], where the costly tapestry, that adorned the walls with pictured exploits of his ancestors, [...] the gorgeous banners, $[\ldots]$ the sumptuous canopies, $[\ldots]$ united to form a scene of magnificence" (Radcliffe 2001: 520/21). Patriarchal power manifests itself in this space. This power, however, is subverted by the appearance of a stranger who, without the Baron's knowledge, has "been secreted in the [latter's] apartment" (Radcliffe 2001: 521), disregarding the privacy of this very intimate space. What is more, the stranger places the Baron in a position of epistemological disadvantage, telling him that he has come "to communicate to him a terrible secret, which it was necessary for him to know" (Radcliffe 2001: 521). Two things happen here: the Baron, as a man, is faced with the fact that he lacks knowledge that supposedly concerns him, a position that, from the point of view of a masculinity that defines itself through an economy of knowledge, is unacceptable. At the same time, in the context of the novel's genre, the Baron takes on the feminised role of 'Gothic heroine,' the stranger's hints 'awaken[ing] a degree of solemn curiosity in the Baron, which, at length, induced him to consent to follow the stranger" (Radcliffe 2001: 521). The Baron's loss of power over knowledge is mirrored spatially in that the stranger "open[s] a secret door, which the Baron had believed was known only to himself $[; . .$.$] the Baron follow[s] in silence and amazement, on perceiving that$ these secret passages [are] so well known to a stranger" (Radcliffe 2001: 523). Not only does the Baron not gain access to the knowledge he is apparently lacking (the stranger "was a moment silent," "frowned, and turned away in silence," and "did not speak" [Radcliffe 2001: 522/23]), but he also loses control over the space - and, hence, knowledge - of his own castle. Only when the Baron has completely exposed himself to weakness and vulnerability, following the stranger to the liminal space of the forest alone, is the spell broken, and the narrative returns to a rhetoric of masculine valour and honour. Until this moment, however, Radcliffe, in this short story-within-a-story, manages to further destabilise notions of absolute masculine control over space and knowledge.

Returning to the main narrative, the loss of spatial power depicted in the tale finds its way into the 'real' world of the novel: when the Count returns to the Marchioness' apartment, he finds it still locked, and Ludovico not answering. Even more than before, the door to the apartment itself seems to deny the master of the house access: The Count "was himself going to strike upon the door [...], when he observed its singular beauty, and with-held the blow" (Radcliffe 2001: 528). The door, in this rhetoric, becomes a personification of the female 'ghost' it is protecting, defying the master's brutal physicality with "the beauty of its polished 
hue and of its delicate carvings" (Radcliffe 2001: 528). When the Count finally does force his way into the apartment through a back door, he finds that Ludivico has vanished, though the doors leading out of the apartment are locked from the inside. This female space not only denies access to the chateau's male master, but it also seems to swallow up male invaders, making them part of its uncannily secret spatiality.

Radcliffe's male characters now increasingly feel the need to fend off a perceived feminine threat. The Count tries to stabilise his position both spatially and epistemologically by literally regaining possession of the keys after leaving the apartment in which Ludovico has disappeared: "The keys of the north apartment I have not suffered to be out of my possession, since he disappeared, and I mean to watch in those chambers, myself, this very night." (Radcliffe 2001: 537) This determination expresses the Count's desire to both be in control of who gets in and out of that part of his house over which, so far, he seems to have lost control, and find out what has happened to his fellow man, adopting Ludovico's role of watchman in a homosocial act of solidarity in the face of an uncanny, feminine “evil spirit" (Radcliffe 2001: 538). The Count, in fact, enters the apartment together with his son Henri. The whole male part of this family seems prepared to defend themselves with all their phallic power, laying "their swords upon the table" (Radcliffe 2001: 538) on entering the Marchioness' rooms. Strikingly, Radcliffe does not show the reader what happens during the night; instead, the next time we encounter the Count and his son, they are even weaker than before. The two men are unwilling - or unable - to speak about what happened: "[P]ress the subject no further, I entreat you; [...] upon every occurrence of the night you must excuse my reserve." (Radcliffe 2001: 539) While secrecy can empower masculinity (although always precariously), the impression here is crucially different: these men's secrecy neither empowers nor threatens them, but instead fundamentally defeats them, making them both unable to know what exactly it is they have experienced (they think they have seen a ghost), and to express what they think they have seen. Their failure to penetrate the secret of the Marchioness' 'closet' disables them to take part in the management of knowledge, both mentally and linguistically. Robbed of knowledge and speech, the Count is finally expelled from his own house: "I mean to change my residence, for a little while, an experiment, which, I hope, will restore my mind to its usual tranquillity." (Radcliffe 2001: 545) Naturally, as in all of Radcliffe's novels, all the narrative's uncanny incidents are ultimately explained as being of a perfectly ordinary nature. For the moment, however, the female 'ghost' of Chateau-le-Blanc has successfully managed to share knowledge with its female visitors (Emily, Dorothée), while holding it back from the men, who lose control over knowledge and space, and, in the end, are even driven from this feminine counterpart of Udolpho. 


\section{A 'Queer House:' La Valée}

Emily's family home in Gascony defies any clearly gendered reading. From the start, this house is 'queered,' as it were, being both deficient in its representation of patriarchal power, and closely associated with the pastoral and nature. The scene surrounding the chateau is one of "pastoral landscapes, [...] gay with luxuriant vines, and plantations of olives, [...] flocks, and herds, and simple cottages" (Radcliffe 2001: 5). St. Aubert himself is not primarily depicted as the patriarchal master of his house, but, instead, as a man whose ambition in life has been tamed by experience, retiring "to scenes of simple nature, to the pure delights of literature, and to the exercise of domestic virtues" (Radcliffe 2001: 5). More strikingly, St. Aubert refuses to fulfil his function as male protector and propagator of his family's wealth: he "had too nice a sense of honour to fulfil the latter hope [of an advantageous marriage], and too small a portion of ambition to sacrifice what he called happiness, to the attainment of wealth" (Radcliffe 2001: 5). In the world of the Gothic, St. Aubert is a deficient male, almost emasculated by his lack of ambition and close association with pastoral settings.

The edifice itself reflects this lack of powerful masculinity: it is "merely a summer cottage [...of] neat simplicity, [...] only a simple and elegant residence" (Radcliffe 2001: 6). As opposed to other Gothic mansions like Udolpho, with its intimidating grandeur and representation of wealth and power, La Valée's interior is characterised by "chaste simplicity" (Radcliffe 2001: 6). The library, traditionally a place of masculine occupation and importance, is pushed towards the liminal through its being immediately adjoined by "a green-house, stored with scarce and beautiful plants" (Radcliffe 2001: 6). St. Aubert, instead of occupying himself with matters of political or social importance in the virtual, homosocial society of letters, often prefers to "seek one of those green recesses" (Radcliffe 2001: 7) in the house's heterotopian vicinity in the female company of his wife and daughter.

Despite La-Valée's deficiencies as a typically 'masculine' architecture, the structure of the Bluebeard plot surfaces once again in its secret spatiality. One night, Emily finds her father in his closet, "weep[ing], and sob[ing] aloud” (Radcliffe 2001: 28). St. Aubert's demeanour in this private space is a mystery to Emily, and she is "detained there by a mixture of curiosity and tenderness" (Radcliffe 2001: 28). Finding that there is something about her father that she cannot understand awakens Emily's curiosity, just as Bluebeard's telling his wife that she must not enter his secret chamber makes her determined to find out what is in it. Emily, however, at first refuses to penetrate her father's secrets, "recollecting that she was intruding upon his private sorrows" (Radcliffe 2001: 28). She tries to control herself despite finding St. Aubert weeping over the picture "of a lady, but not of her mother" (Radcliffe 2001: 28), a fact that must make her suspicious. Emily's will- 
ingness to accept the patriarchal boundaries of knowledge keeps her from finding out more about her father's secret until what she has seen more or less unwillingly (the picture she finds) is contextualised at Chateau-le-Blanc through the more powerful female agency of the dead Marchioness and her female servant.

Of all the male characters in Radcliffe's novel, St. Aubert, the least traditionally masculine of them all, plays the part of Bluebeard most convincingly. Not only does he keep knowledge spatially concealed from his daughter, but he also gives her the key to unveil the secret, while explicitly demanding of her not to do just that: on his dying bed, St. Aubert discloses to Emily the intricate structure of his closet, which "has a sliding board in the floor" (Radcliffe 2001: 76), under which he has hidden "a pack of written papers" (Radcliffe 2001: 76). Having laid open this secret spatiality thus far, however, he denies Emily knowledge of what the secret actually contains. He elaborately reveals how the secret of his past is hidden, but does not fill it with semantic content: "These papers you must burn and, solemnly I command you, without examining them." (Radcliffe 2001: 76) This masculinity feels the need to repeatedly emphasise that it has something to hide in a hypertrophied rhetoric of secrecy, without, however, making the content of the secret itself visible. St. Aubert's move is contradictory: firstly, he - just like Bluebeard - employs Emily with the means of revealing his secret while, at the same time, asking her not to do it; and secondly, while trying to protect his secret from being known to a woman, he accepts that patriarchal lineage has failed, and that a woman can just as well be mistress of his house. He makes Emily promise never to sell the chateau; he "even enjoined her, whenever she might marry, to make it an article in the contract, that the chateau should always be hers" (Radcliffe 2001: 76).

St. Aubert and his house, when it comes to the question of masculinity, seem foreign, contradictory, and strangely 'queer' in Radcliffe's fictional world. Both house and owner hold on to traditional mechanisms of how masculinity defines itself through secrecy and the exclusion of women, but also accept that maybe a future might look different, that masculinity needs to evade misogynistic paranoia, and allow for women to have a space and agency of their own. There is, however, no room (yet?) for such a radical re-thinking of gender roles in the world of this novel; and, accordingly, St. Aubert dies.

When Emily returns to what is "now her own territory" (Radcliffe 2001: 90), she symbolically takes her father's place as mistress of the house by making the library, the centre of masculine, intellectual power, her own: "There was an armchair, in which he used to sit; [...s] he walked slowly to the chair, and seated herself in it." (Radcliffe 2001: 92) Radcliffe further highlights that Emily is now mistress of her own house by having the dog accept her in her father's stead: "[I]t was Manchon who sat by her, and who now licked her hands affectionately." (Radcliffe 2001: 93) Emily's adopting a position of power in the house, however, is 
an ambiguous affair. She can still sense her father's presence, and feels bound to act according to his wishes, even though she has literally taken possession of his house's spatiality. Being about to open the secret hiding place in St. Aubert's closet, Emily looks at another chair, and "the countenance of her dead father appeared there" (Radcliffe 2001: 99). Again, the chair can be read as a symbol of patriarchal power over the household, and Emily's newly-gained position as mistress of La Valée continues to be contested by her own father. Through his last wish to her, he has made sure that she will execute power over this domestic space according to his wishes, even beyond his own death: once Emily has taken the secret papers out from underneath the floorboards, "there appeared to her alarmed fancy the same countenance in the chair" (Radcliffe 2001: 99). When she has a closer look at the papers, she is caught between her curiosity (and actual power of penetrating her father's secret), and the impulse to act according to her father's last wish:

"[H]er eyes involuntarily settled on the writing of some loose sheets, which lay open; and she was unconscious, that she was transgressing her father's strict injunction, till a sentence of dreadful import awakened her attention and her memory together. She hastily put the papers from her; but the words, which had roused equally her curiosity and terror, she could not dismiss from her thoughts. So powerfully had they affected her, that she even could not resolve to destroy the papers immediately." (Radcliffe 2001: 99)

As at other points in the novel, Radcliffe doubles the effect of secrecy on several narrative levels: neither does the reader know what it is that Emily has read, nor what the papers actually say in their entirety; and Emily, only glimpsing a fragment of the whole, jumps to a wrong conclusion, suspecting her father of infidelity, while, as she and the reader learn at the end of the novel, the papers would reveal to Emily that the late Marchioness de Villeroi was her aunt. As it is, her father's denying her access to this knowledge, and her own curiosity lead to the creation of half-knowledge and an increased interest in Emily, and of more suspense for the reader. Emily now openly "lament[s] her promise to destroy the papers" (Radcliffe 2001: 100). However, her sense of filial duty is, for the moment, stronger than her curiosity, and she "consign[s] the papers to the flames" (Radcliffe 2001: 100). It is crucial here that St. Aubert forces Emily into this act of self-censorship, reversing, to a certain degree, the act of handing down to her the power over to the domestic space of La Valée. Emily does, however, find a way to subvert the paternal power she so unquestioningly obeys. Finding the miniature picture of her aunt - she does not know yet that it is her aunt - Emily concludes that it does not fall under her father's dictum: "St. Aubert had given no directions concerning this picture, 
nor had even named it; she, therefore, thought herself justified in preserving it." (Radcliffe 2001: 100)

St. Aubert remains an ambiguous patriarch in the gendered world of Udolpho. On the on hand, he exerts spatial power over women just like Montoni; on the other hand, he seems to have accepted the cultural inadequacy of a strictly male lineage, embodied in the possession of the patriarch's mansion. St. Aubert performs a contradictory masculinity that defines itself through the denial of women's access to knowledge that is already inherent in the Bluebeard myth. While verbally forbidding his wife to enter his secret chamber, Bluebeard, by giving her the key to the room, provides her with the physical means of doing just what he has explicitly asked her not to do. Similarly, St. Aubert, instead of leaving his secret to be forgotten where it is hidden, both orders Emily not to try and find out what it is, and provides her with enough information to do just that - and the 'closet,' once opened, does not threaten Emily, but makes her independent. In St. Aubert, Radcliffe portrays a masculinity that has come to question its own foundations of power, and the very structures on which its self-understanding rests. In this, she is not "a conservative writer[, for whom] the true gothic terrors [...were] the winds of change, dissolution, and chaos, [...] resolutely turning [her] back on modern life" (Durant 1982: 519-520, 530), but a truly revolutionary novelist.

\section{A 'Male Heroine:' William Godwin's Caleb Williams}

Caleb Williams, first published in 1794, has mostly been discussed as an example of social criticism of the state of England at the end of the eighteenth century, often being compared and contrasted with William Godwin's political essay Enquiry Concerning Political Justice. Rudolf Storch criticised decades ago that this was a reductionist approach to the novel; he reads it as a comment on a more general cultural state of mind: "[W]e feel and recognize in the narrative the guilt and the anxieties which seem to have dominated much of Western culture since the end of the eighteenth century." (Storch 1967: 189) I will propose a reading that locates these anxieties at the very heart of modern patriarchal-masculine identities, drawing attention to the emphatically homosocial nature of Godwin's narrative. Avoiding a minoritising reading of the male protagonists as 'homosexual,' it will show these men to be struggling with defining a stable gender identity for themselves, a task that becomes impossible in the light of the paranoia that is an inherent characteristic of end- and post-eighteenth century English masculinities. The relationship between Caleb and Falkland will, in fact, turn out not to be representative of a minority 'sexual' identity at all, but will prove 'queerness' to be at the very centre of modern masculine self-definition. 


\section{A Question of 'Honour:' Chivalric Masculinities}

What characterises the men of Godwin's "narrative of obsession" (Storch 1967: 189) most is a feverish preoccupation with what they call their 'honour' (cf. Monro 1953: 86-108). Falkland, the story's 'Gothic villain,' represents a concept of masculinity that not only fails because of its hyperbolic and manic pursuit of an unblemished 'reputation,' but also feels constantly threatened by Caleb's invading curiosity. Caleb acts as opponent to Falkland, but also turns out to be trapped in the same system of chivalric codes of masculinity, codes which Godwin exposes as both inherent and fatal to his fiction's homosocial world. In Caleb Williams, Godwin creates an elaborate discourse of 'honourable behaviour', and a 'good reputation,' seemingly reaching back to a long tradition of semantically specific codes of conduct. As it turns out, however, none of his male characters ever manage to explicate what 'honour' actually means. Chivalric masculinity, in this novel, remains as much an under-determined category as the homosocial dynamics that rule its interactions; it cannot be defined, but only spoken about, and becomes the focal point of Godwin's protagonists' paranoid attempt to read themselves as 'men' in an economy of knowledge and power that locates paranoia at the very centre of a male-homosocial ideology.

The master-servant relationship depicted in Caleb Williams, and the emerging pursuit of Caleb by Falkland are the result of the characters' efforts to live up to a vision of masculinity that the novel shows to be not only unliveable, but also (self-)destructive. Falkland and Caleb depend on each other for their existence in a homosocial world that draws its ambiguous power from the sharing of secrets, and lives in permanent fear of its own deficiency, and its secrets' disclosure. Joel Faflak makes a similar, yet less gendered, point by showing how Falkland and Caleb define themselves through their conversation with each other in "a kind of interminable dialogue through which each wrestles for a self-mastery that comes only through the control of each other's selfhood" (Faflak 2005: 102).

Godwin's novel is acutely concerned with the paranoid dynamics of male secrecy. Reading the language of the 'closet' he employs as that of the unambiguously 'homosexual closet,' as, for example, do readings offered by Robert J. Corber and John Rodden, would, however, be reductive. Corber sees Caleb Williams as a critique of the aristocracy that was constructed as effeminate and 'sodomitical' by contemporary radical discourse (cf. Corber 1990: 85-89). Rodden reads the novel in purely psychoanalytical terms, claiming that

"Caleb's narration of causally disconnected events and his deep-seated ambivalence toward his master-surrogate father Lord Falkland become understandable when viewed as a fundamentally narcissistic personality unconsciously 
engaged in a homosexual struggle with his omnipotent father. The world of Caleb Williams represents the narrator's search for the ideal family of romance, a projection of Caleb's self, with the various characters serving as different aspects of Caleb's fragmented ego.” (Rodden 2009: 120)

Although these readings, and others that come to similar conclusions (cf. e.g. Gold 1977; Daffron 1995), touch on important points, for example the erotic attachment of Falkland and Caleb, and Caleb's failure to escape his exclusively homosocial world and create a Freudian 'surrogate family,' they do not take into account that the homosocial nature of the conflict between the two men is more deeply embedded in Godwin's depiction of masculinity than a purely psychopathological reading of the novel (with Caleb as 'homosexual narcissist') would be able to show. As William D. Brewer rightly observes, "Caleb Williams is [...] just one of the novels in which Godwin explores the dynamics of masculine relationships, and not all of his male protagonists' attitudes toward same-sex friendship are homophobic" (Brewer 2000: 50). A less minoritising ('homosexual') and more globalising ('queer') approach, hence, will help us see how, in this late example of the Gothic novel, homosocial dynamics of secrecy politics do threaten the characters' masculinities, reverberating with connotations of deviant identity categories that begin to emerge at the time, without, however, being clearly about the men's 'sexuality,' but rather about their gender identity, and how it defines itself around questions of knowledge, power, and eroticism. I will argue that erotic rivalry, for Godwin, is not, as Brewer claims, an unfortunate by-product of male-to-male relationships (cf. Brewer 2000: 50), but the crucial - albeit conflicted - core of modern masculine self-definition. As Brewer himself acknowledges, "[f]or a man to find his true antitype, Godwin's fiction suggests, he must turn to another man" (Brewer 2000: 52).

The reader encounters Falkland early in the story as a man who already bears all signs of having lost the traits of what we later learn to be the novel's concept of 'chivalric' masculinity. Falkland is "a man of small stature, with an extreme delicacy of form and appearance;" his face is "pregnant with meaning," and Caleb can sense "the unquietness of his mind" (Godwin 2005: 7). In these first few sentences we get enough information to recognise Falkland as a Gothic Bluebeard - very much like Walpole's Manfred - who has a secret that threatens his existence from within, both physically and psychologically. Shortly after this first impression, however, Godwin introduces us to a very different, earlier version of this character. As Caleb learns from Mr Collins, Falkland, in his earlier days, used to be very much what we might call 'a perfect, honourable gentleman.' In his dealings with Mr Tyrrel, who is later killed by Falkland, Williams elegantly contrasts two very different, but equally (self-)destructive masculinities. Tyrrel is the untamed, wild 'athlete:' "muscular and sturdy," he is "an expert in the arts of shooting, fish- 
ing, and hunting," activities that provide him with "tenfold robustness and vigour" (Godwin 2005: 19). Tyrrel's rawness makes him more of an animal than a human being when it comes to his relationships with other people. He is despotic and mean, but, nevertheless, the object of admiration and desire for his female acquaintances, who imagine themselves playing with "the fangs of this wild beast" (Godwin 2005: 21). Tyrrel is Falkland's mirror, the epitome of virile masculinity. To Falkland, Tyrrel seems crude and uncultured, and he regards him with a hatred and rivalry that oscillates between envy, self-doubt, and self-affirmation. Falkland is the sophisticated 'aesthete,' whose "cultivated manners were peculiarly in harmony with feminine delicacy" (Godwin 2005: 22). Falkland prides himself on his refinement and dignity. However, Godwin's choice of words to describe him (wit, cultivation, grace, elegance, benevolence, feminine delicacy) position him - on a culturally still reverberating continuum of male and female - dangerously close to being effeminate, a possibility that the narrator explicitly acknowledges, but, at the same time, denies with ironic emphasis ("elegant without effeminacy!" [Godwin 2005: 23]).

Falkland and Tyrrel both represent contrasting, yet equally flawed versions of masculinity, and "the contrast between these two leaders in the field of chivalry" (Godwin 2005: 23) will end in catastrophe. It is no coincidence that the first point of conflict between the two men is the rivalry over a woman at a ball. The main - or, indeed, the only - function of women in Caleb Williams - who, as we will see in more detail later, are never "desirable victims or lovers" (Chatterjee/Horan 2003: 128) - is to be part of a triangle that serves as a catalyst in homosocial power struggles. Falkland, succeeding in being the dance partner of choice for Miss Hardingham - while never showing any kind of 'sexual' interest in her - literally threatens Tyrrel's virility, making "the ferociousness of his antagonist subside into impotence" (Godwin 2005: 25).

Although Falkland's demeanour, in this early part of the novel, makes him a more likable and respected man than Tyrrel, his obsession with chivalric - i.e. medieval and outdated - codes of masculine 'honour' leads to his later, paranoid existence. Falkland takes his model of masculinity from an imaginary past, even composing "An Ode to the Genius of Chivalry" (Godwin 2005: 27). His is a masculinity that values 'honour' - i.e. a good reputation and the protection of his 'good name' - above everything else; and, despite their differences, both Falkland and Tyrrel realise that their world is predominantly homosocial; women play a marginal role, and men need each other as rivals in the contest of becoming the 'better man:' Falkland pleads his "manly and honest purpose" in "the society of men" (Godwin 2005: 32), and Tyrrel admits that "Falkland haunts me like a demon. I cannot wake but think of him. I cannot sleep but see him. [...] I should be glad [...] to grind his heart-strings with my teeth." (Godwin 2005: 33) These examples 
confirm Sedgwick's claim that, in triangles such as this, the bond between the two men is the relevant one, and their rivalry, more often than not, reverberates with intimate and erotic undertones (note the vampiric penetration of Falkland's heart, the symbol of love) (cf. Sedgwick 1985: 21-27; Corber 1990: 92-93).

\section{The Traffic in (Wo)Men: Erotic Triangles and Issues of Class}

The most prominent example of the 'traffic in women' (cf. Rubin 1975) in Caleb Williams is the character of Emily. As Tyrrel's ward, Godwin immediately eliminates her from any kind of 'sexual' economy: "Nearness of kindred, and Emily's want of personal beauty, prevented him from ever looking at her with the eyes of desire." (Godwin 2005: 42) Falling in love with Falkland, Emily becomes the victim of the rivalry between the two men, the object of the destructive energies between them: "Her partiality for the man who was the object of [Tyrrel's] unbounded abhorrence, appeared to him as the last persecution of a malicious destiny[..., and] he determined to wreak upon her a signal revenge." (Godwin 2005: 49) Intending to marry Emily off against her will to keep her from marrying his opponent, Tyrrel reduces her to an object that is traded in the interests and politics of men. He becomes another Gothic Bluebeard, making Emily a prisoner in his house: "This house is mine, and you are in my power." (Godwin 2005: 60) Though Falkland saves Emily at first, this only makes Tyrrel more determined to take out his revenge on Falkland through her: "Let her die! [...] I will not always be insulted." (Godwin 2005: 86) Emily dies as the sacrifice of a masculine rivalry that articulates itself in acts of violence against those who are less powerful. Her death - and the extinction of the female, mediating element between the men triggers Tyrrel's public condemnation as "the tyrannical and unmanly murderer of Emily" (Godwin 2005: 96), and then, in consequence, the bloody conflict between Falkland and Tyrrel that results in Tyrrel's death, and the creation of Falkland's dark secret. Homosocial traffic in women, Godwin demonstrates, leads to Bluebeard's fatal penetration of both the female and the male body, and, ultimately, to a paranoid existence.

The fate of the Hawkins family, tenants of Mr Tyrrel, demonstrates how much both Falkland's and Tyrrel's masculinities define themselves through notions of class and dependence. The younger Hawkins becomes part of a wholly male triangle when Tyrrel decides, against the older Hawkins' will, to take the son into his household. This plan becomes something of an obsession with Tyrrel, and "every time he saw the boy his desire of retaining him in his service was increased" (Godwin 2005: 73). When the older Hawkins, mostly for reasons of lower class self-esteem ("I will not make a gentleman's servant of him." [Godwin 2005: 74]), finally 
refuses to give his son up to Tyrrel, a power struggle over questions of masculine 'honour' ensues, with Tyrrel being enraged at Hawkins ("I made you what you are." [Godwin 2005: 73]) for not getting what he wants, namely the boy who he is "desirous of taking into favour" (Godwin 2005: 73). Two things are of interest here: that Hawkins is so frightened of his boy being corrupted by Tyrrel ("I cannot risk my boy's welfare, when I can so easily, if you please, keep him out of harm's way." [Godwin 2005: 73]); and that, in his decision to stand against Tyrrel, he argues from a point of view of masculine 'honour' different in grade, but not in nature, from that of the aristocratic squire ("I am a man still." [Godwin 2005: 75]). The dynamics are similar to those in a male-male-female triangle: the older Hawkins and Tyrrel are rivals for the better concept of masculine 'honour,' and, in their rivalry, fight over who gets to form the younger generation's 'masculinity.'

Codes of masculine 'honour' in Caleb Williams are not exclusive to a certain class. Rather, conflicts emerge when two different kinds of 'honour' clash. Masculine 'honour' is depicted as selfish and narcissistic. Mr Collins comments on this, referring to the chivalric or 'gentlemanly' tradition of duelling: "Duelling is the vilest of all egotisms." (Godwin 2005: 102) The men in this world feel the need to live up to (imagined or real?) expectations from others, a task in which all of them fail, both being destroyed by others, and destroying themselves.

\section{A 'Male Heroine:' Dynamics of Homosocial Secrecy between Caleb and Falkland}

The second and central male-male pairing in Caleb Williams is the one between Falkland and Caleb himself. Unlike Falkland and Tyrrel, "Caleb and Falkland are determined not to triangulate their desire for each other" (Corber 1990: 93). This relationship works on four different axes of gender and class: master-servant, secrecy-curiosity, homosocial secret sharing, and paranoid homosocial desire, all four elements suggesting potentially homoerotic undertones. From the novel's first pages, Caleb is presented to the reader as a man for whom curiosity is the "spring of action which, perhaps more than any other, characterised the whole train of [his] life" (Godwin 2005: 6). This curiosity, which, in the course of the novel, will be the cause of most of Caleb's sufferings, makes him a dangerous and subversive element in the homosocial world of Godwin's narrative. He is a deviant being; his disrespect for the secrets of other men is reminiscent of female Gothic heroines like Radcliffe's Emily, or the young woman opening Bluebeard's secret chamber. Godwin himself acknowledges the similarities between Caleb Williams and the Bluebeard tale, even alluding to the cross-gendered parallel between Caleb and Bluebeard's wife: "Falkland was my Bluebeard, who had perpetrated atrocious crimes, which if discovered, he might expect to have all the world roused to re- 
venge against him. Caleb Williams was the wife, who in spite of warning persisted in his attempts to discover the forbidden secret." (Godwin 2005: 353) This association is confirmed by Caleb's self-characterisation: "My simplicity, arising from my being a total stranger to the intercourse of the world, was accompanied with a mind in some degree cultivated with reading." (Godwin 2005: 113) He is the inexperienced 'male heroine' who is suddenly faced with the grimness of the 'real world' after having been brought up in a well-protected environment. Curious Caleb is bound to collide with a homosocial world - embodied by Falkland - whose greatest fear is a fear of disclosure. Caleb's position is particularly precarious, because not only does he behave like a female Gothic heroine, but he does this from a position of close homosocial intimacy, being Falkland's secretary, the keeper of books and secrets in the master's 'closet' (cf. Stewart 1995). The ambiguity of both being part of the homosocial order, and subverting it - by transgressing (genre-) normative forms of 'masculine' behaviour like the respect for other men's reputation - explains Falkland's strange attitude towards Caleb: he both shares more and more intimate knowledge with Caleb - "[H] virtually seduces Caleb into violating his "privacies." (Corber 1990: 92) - and, at the same time, is irritated by Caleb's prying: "You set yourself as a spy upon my actions. [...] Do you think you shall watch my privacies with impunity?" (Godwin 2005: 10) Falkland is both desirous of sharing his secret with a fellow male, and unsure of Caleb's position in the world of masculine 'honour.'

Caleb himself is fascinated by his master's secrets, but has difficulties respecting the boundaries that his position asks of him: "I understood that secrecy was one of the things that was expected from me." (Godwin 2005: 10) Mr Collins' account of Falkland's earlier life, however, "tend[s] to inflame [his] curiosity" (Godwin 2005: 11). Caleb starts to spy on his master, and finds "a strange sort of pleasure in it" (Godwin 2005: 112), a pleasure that appears to be close to something like sexual pleasure, "a kind of tingling sensation not altogether unallied to enjoyment" (Godwin 2005: 113).

It becomes obvious in the course of the novel that, just like Falkland's obsession with his reputation and the ensuing hunt of Caleb seem to become a necessity for him, Caleb himself more and more defines himself through Falkland and his secret. Falkland and Caleb become mutually dependent counterparts that both need and destroy each other. Caleb realises that they are drawn to each other, but cannot name the reason: "I found a thousand fresh reasons to admire and love Mr Falkland. [...] There was a magnetical sympathy between me and my patron." (Godwin 2005: 112, 117) Caleb keeps repeating his admiration and love for his master, "borrow [ing] from the language of courtship to describe his relations with his patron" (Corber 1990: 92), a love that does not fade despite the fact that Falkland eventually drives him out of society and into near-madness; and Falkland, though he realises 
early on that Caleb might be dangerously curious, keeps him in his service: "Mr Falkland would not hastily incline to dismiss me." (Godwin 2005: 119)

Falkland's paranoid 'closet,' it soon becomes clear, is a result of his obsession with 'honour.' Mr Collins, having told Caleb the story of his master's past, names the curse of Falkland's life: "He was too deeply pervaded with the idle and groundless romances of chivalry, ever to forget the situation [of being publicly insulted], humiliating and dishonourable according to his ideas." (Godwin 2005: 101) Falkland - as we find out in the end - indeed commits a murder for honour's sake, creating a secret that, from then on, defines and tortures him, driving him into the 'closet' of his own codes of masculinity, which he is unable and unwilling to alter or compromise. The preservation of his 'honour' increasingly becomes the sole purpose of Falkland's life, and the question arises whether it could be any different, or whether this - albeit self-destructive - obsession is a necessity he could not live without. It is crucial to note that it is not only the 'private,' suppressed secret of the murder that slowly destroys Falkland, but also the 'public' show of a potential guilt in form of the trial. While the secret preserves his 'public' honour, but gnaws at him from within, the public blemish of the trial works in a similar way: "It is not in the power of your decision to restore to me my unblemished reputation, to obliterate the disgrace I have suffered." (Godwin 2005: 105) Public opinion is soon convinced of Falkland's innocence and 'honourable' character, but Falkland is driven into eternal paranoia by the possibility of public shame: "Reputation has been the idol, the jewel of my life." (Godwin 2005: 106)

Caleb is willing to go increasingly further in his search of Falkland's secret, penetrating deeper and deeper on two levels: Falkland's mental world (in their conversation) and Falkland's house (Caleb feels tempted to go look for the locked trunk in the secret chamber). The spatiality of the house parallels Falkland's psyche, and Caleb looks for the secret on both the metaphorical and the actual, spatial level.

Caleb, however, not only tries to find out Falkland's secret; he wants Falkland to know that he tries. Having read a letter from Hawkins to Falkland that suggests to Caleb that Hawkins, in all probability, did not commit the murder he was convicted for, Caleb reflects: "I was willing that the way in which it offered itself to his attention should suggest to him the idea that it had possibly passed through my hands." (Godwin 2005: 121) Shortly afterwards, Caleb alludes, in front of Falkland, to people who were falsely convicted of a crime they did not commit. His master's reaction is strangely ambiguous: "He came up to me with a ferocious countenance, as if determined to force me into a confession. A sudden pang however seemed to change his design." (Godwin 2005: 122) The two men have started to play a game of power that has the structure of an 'open secret:' Caleb cannot know for sure that he knows something, but wants Falkland to know that he might. 
Falkland, on the other hand, cannot know whether Caleb actually knows what he thinks he might know, and cannot openly react to the allusions.

Falkland is caught between wanting someone to share his secret with, and Caleb's inadequacy for such a task: Both Caleb's social rank and his (from Falkland's point of view) ambiguous masculinity make him an impossible confidant, an "insolent domestic. Do you think I will be an instrument to be played on at your pleasure, till you have extorted all the treasures of my soul?" (Godwin 2005: 124) The double meaning of 'extorted' - 'extract' and 'blackmail' - foregrounds Falkland's paranoid awareness of his own blackmailability.

Falkland fears and depends on Caleb; and, similarly, Caleb, instead of checking himself in the face of danger, seems all the more intrigued and admiring: "Sir, I could die to serve you! I love you more than I can express. I worship you as a being of superior nature." (Godwin 2005: 126) Here, Caleb goes a step too far: he disrespects both the class boundaries that make it impossible for him to become Falkland's intimate confidant, and the unspoken rules of the homosocial 'open secret,' namely that its dynamics of desire remain unnamed and deniable. Caleb can be Falkland's secretary, his servant, and Falkland might live in the unconscious hope of being able to use Caleb as a deposit for his secret; but the secret is too powerful, and class considerations make Caleb not trustworthy enough in Falkland's eyes.

Falkland's ambiguous relationship with his secretary makes it impossible for him to let Caleb go: He wants Caleb to know, cannot let him fully know, and does not know what Caleb knows exactly. Falkland has lost the full power over his secret knowledge, and Caleb is aware of this: "[W]e were each a plague to the other; [...] he did not determine to thrust from him for ever so incessant an observer." (Godwin 2005: 128) Caleb is very much aware of the potential power he could achieve by getting closer to his master and his secret.

The novel first reaches a climax when Caleb realises that Falkland must be the murderer. His intimacy with his master has increased to a degree that bodily signs suffice for both to 'know:' "[W] exchanged a silent look, by which we told volumes. Mr Falkland's complexion turned from red to pale, and from pale to red. I perfectly understood his feelings." (Godwin 2005: 132) Falkland, however, can only be sure that Caleb is sure because Caleb speaks the unspoken, in a garden, a space of heterotopian possibility: "I exclaimed, in a fit of uncontrollable enthusiasm, "This is the murderer." (Godwin 2005: 135) Sure of his knowledge, Caleb is also as certain as never before of his love for Falkland: "I was never so perfectly alive as at that moment. [...I]t was possible to love a murderer." (Godwin 2005: 135/136) In this moment of perfect mutual awareness of a shared secret, the bond between the two men is as strong, and as unacknowledgeable, as never before. Falkland overhears him, the secret is out, and the game must change in character. 
Falkland's secret is no longer safely concealed, and, accordingly, the metaphorical edifice of his life, and the actual edifice of his home begin to crumble.

\section{The 'Closet' of Honour - The 'Closet' of Society}

Falkland's secret is concealed both psychologically, and in an actual space. Godwin introduces Falkland's closet on the first pages as the central locus of the novel's energy, a space that is hidden deeply in the most private parts of his mansion, "separated from the library by a narrow gallery that was lighted by a small window near the roof" (Godwin 2005: 9). One day, Caleb finds his master in the closet where he is facing his dark secret in agony:

"As I [Caleb] opened the door, I heard at the same instant a deep groan, expressive of intolerable anguish. The sound of the door opening seemed to alarm the person within; I heard the lid of a trunk hastily shut, and the noise as of fastening a lock. I conceived that Mr Falkland was there, and was going instantly to retire; but at the same moment a voice, that seemed supernaturally tremendous, exclaimed, 'Who is there?'” (Godwin 2005: 9)

The secret is multiply hidden: in a locked trunk, in the master's closet, in a corridor behind the library. It is kept in the most private and secret space imaginable, serving as a spatial metaphor for the way Falkland tries to lock away the awful secret of his past in the deepest recesses of his own mind, so that no one can ever find it. At the same time, the secret is always on the brink of being exposed, both psychologically and spatially. Caleb finds the secret chamber, and knows of the existence of the trunk. He does not know the secret yet, but he knows of it. While he gets more and more intrigued by Falkland's secret psychology, he is simultaneously drawn to finding out about the trunk's secret content. Falkland's own desire to face and acknowledge his past - he seems inclined to confide in Caleb - is mirrored by his actually going into the closet to open the trunk and ponder over what is concealed within. Spatial metaphor and mental mechanism work hand in hand: the secret of the mind and the secret in the closet are inseparable.

Accordingly, when Caleb is finally convinced of Falkland's guilt, and Falkland overhears him in the garden, the ensuing damage to the structures of the 'closet' is inflicted both mentally and spatially: directly after the (half-)encounter between Caleb and Falkland, a fire breaks out in Falkland's house, with "one of the chimneys" (Godwin 2005: 137) being on fire as a fitting phallic symbol of Falkland's threatened masculinity. Falkland fears for the whole of his life, which is built on a 
good 'reputation,' just as "[s]ome danger was apprehended for the whole edifice" (Godwin 2005: 137).

Although Caleb insists that his "object had been neither wealth nor the means of indulgence, nor the usurpation of power" (Godwin 2005: 139), acquiring knowledge of Falkland's secret does put Caleb in a position of relative power over his master, if not in a political - no one will believe Caleb because of his low and Falkland's high social standing, and Falkland's "social status empowers him to use the available political and juridical structures to his advantage" (Chatterjee/Horan 2003: 128) - then in an intimately homosocial way, making Falkland even more dependent on him. Falkland can now no longer uphold the precarious 'open-secret' relationship that he has so far had with his secretary. Instead, he chooses to openly share his secret with his servant, creating an even closer bond between them: "You must swear, [...y] ou must attest every sacrament, divine and human, never to disclose what I am now to tell you." (Godwin 2005: 141) Once the 'open secret' has been spoken, the only way to fix the breaking homosocial bond is for the two men to become secret sharers in order to preserve masculine 'honour:' "Insulted, disgraced, polluted in the face of hundreds, I [Falkland] was capable of any act of desperation." (Godwin 2005: 141) By making Caleb the confidant of his paranoid 'closet,' he creates a bond between them that makes them more inseparable than two lovers: "To gratify a foolishly inquisitive humour, you have sold yourself. [...] I shall always hate you." (Godwin 2005: 142) Yes, but he will also never let Caleb out of his sight or out of his life again.

Sharing Falkland's secret makes Caleb a prisoner in several ways. He voluntarily decides never to disclose Falkland's secret, sharing his mental 'closet:' "I was tormented with a secret of which I must never disburden myself." (Godwin 2005: 144) At the same time, Caleb becomes a prisoner in a more concrete, spatial sense: From being imprisoned in Falkland's house, he goes on to being locked away in an actual prison, the public 'closet' of all of society's unwanted individuals.

In the prison, a dark and filthy place full of "gloomy passages[...,] the doors, the locks, the bolts, the chains, the massy walls and grated windows" (Godwin 2005: 184; 188) make it clear that what is contained in here is not supposed to get out again. Here, society's rules do not apply, the prisoners have no more rights; they are at the mercy of their jailors: "Their tyranny had no other limit than their own caprice." (Godwin 2005: 187) The prisoners are shut away, from the outside and from each other, from any human contact: "Our dungeons were cells, $71 \frac{1}{2}$ feet by $6 \frac{1}{2}$, below the surface of the ground, damp, without window, light, or air, except from a few holes worked for that purpose in the door." (Godwin 2005: 187) The prison cells share some properties with the closets of mansions like Falkland's, only the purpose is perverted: the prison dehumanises society's criminals and deviant outcasts, and makes them part of a shared knowledge that is suppressed in the 
'mind' of their own culture. They are "those whom society has marked out for her abhorrence" (Godwin 2005: 189), and become the unspeakable secret that must be contained and put away, the excrement of a society that cannot tolerate rule-breakers, be it by a breach of the written law of the courts or - more accurately in Caleb's case - by endangering the law of the patriarchal order, knowing too much about the secrets of the powerful.

Whoever tries to break out of the prison is brought back to be shut away further down, further back in this space that so aptly symbolises the workings of the human mind, suppressing unwanted and tabooed knowledge to the most obscure recesses of the mind, never to be discovered. Caleb, after an unsuccessful attempt to escape, is "conducted to a room called the strong room, the door of which opened into the middle cell of the range of dungeons. It was underground, [...] the air was putrid; and the walls hung round with damps and mildew." (Godwin 2005: 208) Just as Christopher Marlowe's Edward II, Caleb is locked in a collective cultural 'closet,' only the reasons are different: Edward does not realise that his royal body is only inviolable so long as he respects that this body cannot have a 'private' life in the modern sense of the word. Caleb enters into a homosocial bond of power politics, and realises too late that, being of a lower social rank than Falkland, he can only be his equal on a psychological, but not on a social level. David Collings rightly reads Caleb Williams, and especially Godwin's depiction of the legal system, as "a systematic critique of every kind of institution, arguing that people should live under the immediate authority of reason itself" (Collings 2003: 847). What Godwin ultimately criticises - and is fascinated by - is the male-homosocial order with its paranoid mechanisms of policing and suppression, embodied by the police and the law.

\section{The Structure of the Chase}

The whole third volume of Caleb Williams is dedicated to Caleb's flight from the hands of Falkland after his escape from the prison. From the fairy-tale architecture of the thieves' lair to the modern anonymity of London, the reader follows Caleb to the point of physical and psychological exhaustion. This chase has two astonishing characteristics: firstly, Falkland, while being determined to ruin Caleb's reputation and make him a social outcast wherever he can to destroy his credibility, nevertheless goes out of his way to keep Caleb both from dying, and from leaving England; and, secondly, Caleb, though driven to near-extinction by Falkland, both is determined, almost to the last, never to disclose his former master's secret, and never loses his feelings of admiration - and even love - for Falkland. Both men destroy and are obsessed with each other. 
This ambiguously erotic chase is worth analysing in more detail with regards to its homosocial dynamics. The episode of Caleb's short association with the group of thieves is set in a Gothic landscape and architecture that is strongly reminiscent of fairy-tales, featuring a reputedly haunted forest, and "a pile of ruins" that contains, beyond "a winding passage that was perfectly dark" (Godwin 2005: 222), the thieves' secret hideout. Here, we encounter another of Godwin's female characters who will never be a sexual object, but rather, being described as uncannily gender-unspecific, both supports and potentially subverts the male-homosocial community: the witch, or Bluebeard's female helper. The woman, who lives with the thieves, seems to Caleb "extraordinary and loathsome[...,] uncommonly vigorous and muscular," and she has "a voice [...] which for body and force might have been the voice of a man, but with a sort of female sharpness and acidity" (Godwin 2005: 222). Mr Raymond, the head of the all-male group of thieves, seems to have a certain amount of authority over the woman. She, however, at least at times, keeps the keys to the house, and it is her presence that keeps unwanted company away from the place that has "the reputation of being haunted" (Godwin 2005: 229). The woman is believed to be a witch, causing supernatural lights, and taking part in "a carnival of devils" (Godwin 2005: 229). Contrary to first appearances, this is not a space of absolute male power. Instead, it is strongly influenced and subverted by the ambiguously female power associated with witchcraft.

The witch-woman is the dominating presence in the house, and the men are left to play their games of power under her observation. Although Caleb claims that "[t]he persons who composed this society had each of them cast off all control from established principle" (Godwin 2005: 226), the thieves actually do copy established structures of homosocial power relations in the military, calling their leader 'captain,' and following certain rules of obedience. Although outcasts themselves, these men still adhere to the same codes of masculine 'honour' that are constitutive of the society that has outlawed them. One of the thieves, Gines, who has earlier attacked the helpless Caleb, is expelled from the group because his behaviour is considered 'dishonourable:' "I [Raymond] vote that Gines be expelled from among us as a disgrace to our society." (Godwin 2005: 225)

Gines is the most fascinating minor character in Caleb Williams, because he seems, at first, to be the only man who does not live according to principles of 'honour' and 'reputation' (although, in the end, he will turn out to be just as driven by these codes as the other characters). His attitude is pragmatic, albeit often cruel: he does what is best for himself, his own survival, and that of his peers. He has principles, but they are not 'honourable' at first glance. When asked why he abused Caleb, he simply answers: "He had no money." (Godwin 2005: 224) His actions, however, are not all random: "I was always true to my principles." (Godwin 2005: 225) What distinguishes Gines from the other male characters is that his ideas of 
'honour' will never make him turn against himself. His sense of self-esteem lacks the masochistic quality that we see in Falkland and Caleb. These characteristics make Gines the most ruthless of the novel's characters - and the one who is most apt to survive. They also make him an efficient helper of Falkland's in the latter's pursuit of Caleb, since he will act out Falkland's destructive will more ruthlessly than Falkland's own sense of 'honour' would allow him. I will pick up this issue again at a later point.

Caleb, as opposed to Gines, fully engages in the masochistic game of homosocial, secretive bonding. At this point in the story, he is still prepared to keep Falkland's secret, but calls him both his "protector" and "persecutor" (Godwin 2005: 228), aptly summarising his ambivalently close relationship with his former master. He does not want to disclose his knowledge due to "the possibility of its being made use of to the disadvantage" (Godwin 2005: 228) of Falkland. Raymond, aware of the workings of homosocial intimacy, does not find this kind of behaviour suspicious, and respects Caleb's secrecy. He appears to instinctively understand the nature of Caleb's situation, and how vital his secret is for him. Raymond, in fact, correctly guesses Caleb's transgression: He tells the other thieves that Caleb, "because he wished to leave the service of his master, because he had been perhaps a little too inquisitive in his master's concerns, and because, as I suspect, he had been trusted with some important secrets, his master conceived an antipathy against him" (Godwin 2005: 232). What makes Caleb worthy of protection in the eyes of Raymond, in the end, are questions of status: "Shall we, against whom the whole species is in arms, refuse our protection to an individual more exposed to, but still less deserving of their persecution than ourselves?" (Godwin 2005: 233) Their common situation as outcasts creates a bond of loyalty between the thieves and Caleb, and their own codes of 'honour' protect Caleb - for the moment at least - from Falkland: "If fidelity and honour be banished from thieves, where shall we find refuge upon the face of the earth?" (Godwin 2005: 233)

Caleb is eventually driven out of his residence with the thieves by the power of the witch-like woman, "the infernal portress of this solitary mansion" (Godwin 2005: 237), who, in a scene that turns Gothic stock plots upside-down, again puts Caleb in the position of helpless female heroine when he is lying in bed, and suddenly perceives "the execrable hag [...] standing over me with a butcher's cleaver" (Godwin 2005: 239). Shortly before, Caleb falsely assumes a male enemy approaching, listening to "his constrained yet audible breath" as "[h]e came up" (Godwin 2005: 239, emphasis mine), reinforcing the impression of reversed gender roles on the reader. This woman is associated with a feminine power and violence that threatens to subvert the patriarchal order: "Her vigour was truly Amazonian." (Godwin 2005: 240) She almost succeeds in both destroying Caleb physically, and robbing him of his spatial freedom: "II will sit upon you, and press you to hell! I 
will roast you with brimstone, and dash your entrails into your eyes! [...] I will be the death of you yet: you shall not be your own man twenty-four hours longer!' With these words she shut the door, and locked it upon me." (Godwin 2005: 240/41) A masculine order, in this house, only ever exists on the brink of its undoing, due both to the precarious stability built on the thieves' 'honour,' and to the presence of a subversive femininity that initially seems to be a 'female helper,' but, in the end, turns out to question traditional modes of gender, and threatens to either shut men in or turn them out.

Caleb eventually manages to escape, only to face animosity wherever he goes. Falkland has managed to make Caleb the object of common fear and disgust. Strikingly, what appals people most about Caleb's alleged depravity is his disrespect for the spatial boundaries of class and law: he is known as "the notorious housebreaker, Kit Williams" (Godwin 2005: 244). A man in the street is astonished "that he should have been so hardened as to break the house of his own master at last, that is too bad" (Godwin 2005: 244). A woman admires Caleb because "he outwitted all the keepers they could set over him, and made his way through stone walls as if they were many cobwebs" (Godwin 2005: 246). Caleb's willingness and ability to transgress society's spatial borders of lawful and 'honourable' conduct makes him uncannily dangerous.

Caleb can only escape from the omnipresent danger of being recognised in public by starting to perform roles, a task at which he considers himself very talented: "From my youth I had possessed a considerable facility in the art of imitation." (Godwin 2005: 246) He starts to change his movements, and adopts an Irish accent. At the same time, however, Caleb regards this sort of performance as inherently unmanly: "Such are the miserable expedients and so great the studied artifice which man, who never deserves the name of manhood but in proportion as he is erect and independent, may find it necessary to employ." (Godwin 2005: 247) To hide behind artifice and performance, in the eyes of Caleb, unmans a man, makes him 'unworthy,' and, clearly, is not 'honourable.' Ironically, masculinity, in Caleb Williams, through the characters' obsessive pursuit of 'honour,' is itself exposed as a performance, albeit one that claims to be original and 'real.' Caleb's 'unmanly' performance alludes to the meta-level of the pursuit of an 'honourable' masculinity that most of the male characters in the novel follow, and in which they fail. Trying too hard to be 'men' of a 'good name' and a 'good reputation,' Falkland and Caleb equally drive themselves and each other into madness and extinction.

Men, Godwin demonstrates in Caleb Williams, are the fools of 'honour.' This is also true - in more or less vital ways - for minor characters, for example the two men who arrest Caleb on the ship to Ireland. When they realise their mistake (he is not the Irishman they had been looking for), they cannot admit their mistake to themselves: "[T]hey had gone too far for it to be possible they should retract in 
consistence with their honour." (Godwin 2005: 251) In this short episode, Godwin summarises his image of men as portrayed in this novel:

"Every man is, in his different mode, susceptible to a sense of honour; and they [the two men] did not choose to encounter the disgrace that would accrue to them if justice had been done. Every man is in some degree influenced by the love of power; and they were willing I should owe any benefit I received, to their sovereign grace and benignity, and not to the mere reason of the case." (Godwin 2005: 254)

Masculinity, this passage suggests, is about having power over others, and being in control of one's own 'honour' and 'reputation.' This is easily applicable to Caleb and Falkland: Falkland needs to be intellectually and spatially in control of his secret knowledge and, in extension, of Caleb. This is what constitutes his masculinity. The same is true for Caleb: his sense of 'honour' depends on his retaining control over Falkland's secret. Without it, he would be powerless, and a 'lesser man.' That is why - almost until the very end - he is unwilling to disclose what he knows.

Having realised that Falkland will not let him flee the country and out of his reach, Caleb decides to try and hide in the liminal anonymity of the city, and goes to London to vanish "amongst the crowds of the metropolis[...,] a place in which, on account of the magnitude of its dimensions, it might well be supposed that an individual could remain hidden and unknown" (Godwin 2005: 259; 271). The modern city, with its dissolution of traditional social bonds, and a tendency of people to withdraw into a new sphere of domestic privacy, provides Caleb with a certain amount of anonymity. London is "an inexhaustible reservoir of concealment to the majority of mankind" (Godwin 2005: 263). Caleb also further perfects his disguise, adopting the appearance of a Jew, escaping the dangerously suspicious existence of an outlaw by pretending to be part of a minority that lives on the borders of spatial and social acceptance, and is therefore not the focus of particular attention. Spatially, Caleb makes his concealment complete by withdrawing to a private apartment in which he "constantly secluded [him]self from the rising to the setting of the sun" (Godwin 2005: 264). Thus multiply hidden, Caleb leads a shadow life in constant fear of discovery: "In every human countenance I feared to find the countenance of an enemy. I shrunk from the vigilance of every human eye." (Godwin 2005: 264) This is the rhetoric of the 'closet.' Caleb's alleged crime makes him a stained being, cast out by society, and forced into a paranoid existence, spatially and mentally imprisoned: "I was shut up, a deserted, solitary wretch in the midst of my species. [...] My life was all a lie. I had a counterfeit character to support. I 
had counterfeit manners to assume. [...L]ike a frightened bird, [I] beat myself in vain against the enclosure of my cage." (Godwin 2005: 265)

It is no coincidence that Godwin has Caleb find a last refuge in writing, at a time when English society was increasingly occupied with questions of individuality and the inner life, with novels being the new literary expression of a private domesticity that was more and more appreciated, especially by the emerging middle classes. Ironically, however, it is Caleb's published writing that finally leads to his being discovered by Gines.

This second personal enemy of Caleb's now turns out to be just as driven by a sense of masculine 'honour' as the novel's other male characters. In contrast to most of the other men, however, who pursue more or less widespread, 'common' notions of 'honour,' Gines reveals these definitions to be arbitrary, following self-fashioned rules of his own that contradict those of the other characters, but are logical enough in themselves. Gines decides to take out his revenge solely on Caleb, because it is his rule never to betray people who have been his accomplices before. However, "though Gines was in this sense of the term a man of strict honour, [Caleb's] case unfortunately did not fall within the laws of honour he acknowledged" (Godwin 2005: 270). Every man, it seems, defines his own notion of 'honour;' the only common ground of these definitions is a rather nebulous sense of chivalric 'manliness' that, once threatened, triggers mechanisms of violence and paranoia. In Gines' case, Caleb's crime is to have 'unmanned' him by turning him into an 'honest man:' he now works as a thief-hunter, an occupation that is nothing like "the liberal and manly profession of a robber" (Godwin 2005: 270).

In Gines, Godwin ridicules the fantastic nature of the 'manliness' his characters try to live up to, an attempt at which they fail precisely because of the arbitrariness and lack of actual semantic content of words like 'honour,' 'reputation,' and 'manly.' Gines, just as Falkland, derives meaning from hunting down the man who has allegedly damaged his 'honour:' "He spared neither pains nor time in the gratification of the passion, which choice had made his ruling one." (Godwin 2005: 271) Gines projects his frustration at his instable 'masculine' identity on Caleb, who becomes his obsession.

\section{Disclosing the Secret}

Although Godwin goes to extremes to keep up the unresolved tension between Falkland and Caleb (and Gines), without having Caleb disclose his pursuer's secret, the novel reaches its climax with the final public revelation and ensuing catastrophe; or rather, Caleb has to attempt twice to make justice believe him. Both scenes are telling concerning the dynamics of the bond between the two men. 
Having escaped Gines in London by the skin of his teeth, Caleb finally decides to reveal Falkland's secret. He emphasises that this resolution is only the result of his now undeniably unbearable situation: "I had long cherished a reverence for him which not even animosity and subordination could destroy[;...but now] I lost all regard to his intellectual greatness, and all the pity for the agony of his soul. Was it wise in him to drive me into extremity and madness? Had he no fears for his own secret and atrocious offences?" (Godwin 2005: 284)

The answer to the last question is twofold: judging from what we have seen so far of the relationship of the two men, it is safe to say that Falkland can, to a certain extent, be sure that Caleb will keep his secret safe. He knows that Caleb wants to preserve their bond just as much as he does himself. On the other hand, Falkland behaves the way he does because he cannot help it. In his paranoia, he can neither let Caleb out of his sight, nor let him live undisturbed.

When Falkland does confront Caleb privately, his body is the physical display of the destructive dynamics of his paranoia: "His visage was haggard, emaciated, fleshless[..., being burnt and parched by the eternal fire that burned within him." (Godwin 2005: 290/91) He explicitly reminds Caleb of the necessity of the bond between them. He needs to keep Caleb alive, but, at the same time, keep him from disclosing their shared secret, which would, as Falkland is aware, result in the death of one or both of them:

"“[T]he preservation of your life was the uniform object of my exertions. [...] I knew you could not hurt me. [...] You have sought to disclose the select and eternal secret of my soul. Because you have done that, I will never forgive you.' [...] There was something in the temper of [Falkland's] mind that impressed him with aversion to the idea of violently putting an end to my [Caleb's] existence; at the same time that unfortunately he could never deem himself sufficiently secured against my recrimination so long as I remained alive." (Godwin 2005: 291/92, 315)

What this 'something' is that keeps Falkland from killing Caleb remains unspoken; but this seemingly contradictory attitude towards Caleb again reveals that he is both the basis of Falkland's existence, and its eternal threat. Falkland's only attempt at making their situation more stable - namely forcing Caleb to sign a declaration of Falkland's innocence, a declaration that would safely restrict knowledge of the secret to the pair - fails because of Caleb's own sense of class and 'honour:' he refuses to "sign away [his] own reputation for the better maintaining of [Falkland's]" (Godwin 2005: 293). Caleb's problem, here, is that, on the one hand, keeping his master's secret is the 'honourable' thing to do; at the same time, however, he cannot publicly declare himself a thief and a liar without acting contrary 
to his own self-esteem. Leaving aside questions of justice, Caleb's signing this contract would, in fact, potentially stabilise the precarious bond between himself and his former master; and although Falkland threatens to exercise "a power that shall grind [Caleb] into atoms" (Godwin 2005: 294), he actually continues to avoid inflicting any physical harm on Caleb.

The last - and naturally futile - attempt at escape from his destructive homosocial bond with Falkland leads Caleb to the novel's last important female figure: Laura, a young woman he meets and lives with for a while, hiding from Falkland. As all the other female characters preceding her, she exists outside the realm of sexual possibility for Caleb. She is the story's mother figure, the only potential refuge for a man like Caleb, who is so fatally caught up in the workings of the homosocial order. The possibility of a heterosexual bond never suggests itself in Caleb Williams. Women are either objects of male-to-male power struggles in triangular structures (Lady Lucretia, Emily), asexual or gender-ambivalent female helpers (the witch-woman), or mothers (Laura). Kenneth W. Graham reads the absence of heterosexual love interest in Godwin's novel solely as the result of the author's dislike of the institution of marriage, and an "antipathy to the sentimental delusions encouraged in the conventional novel" (Graham 1990: 17), ignoring the homosocial dynamics highlighted by this exclusion of women. None of Godwin's women can help Caleb and Falkland in their struggle to find an adequate masculine identity: "This coldness from Laura, my comforter, my friend, my mother! To dismiss, to cast me off for ever, without one thought of compunction!" (Godwin 2005: 308) Some of the women, indeed, seem to deny themselves to the men precisely because they are themselves excluded from male-homosocial power and knowledge. The witch-woman hates Caleb because he is a potentially subversive element in the sphere of domestic female power she has established for herself in an all-male, misogynistic environment; and Laura, in the end, does not cast Caleb off primarily because of his alleged crimes, but because he has not shared his secret knowledge with her: "Is it possible, if you had been honest, that you would not have acquainted me with your story?" (Godwin 2005: 310)

Being thus denied peace once again, Caleb rejects the 'closeted' existence into which Falkland is trying to force him, and determines not to employ any kind of disguise any more, since "life was not worth purchasing at so high a price" (Godwin 2005: 315). This determination, in fact, is of a double nature: by refusing to sign the above-mentioned contract, Caleb rejects making explicit the 'closet' shared with Falkland (based on the 'honourable' assumption that a legally binding promise will keep Caleb from speaking); and by finally refusing disguise and flight, Caleb also opts against living in the 'closet' of social self-denial (a possibility that is equally foreclosed by Falkland's inability to leave Caleb alone). 
Caleb realises that he will always remain a prisoner of Falkland's at the hands of Gines, 'closeted' both by his being under constant pressure from without, and his own unwillingness to disclose what he knows. Gines reminds him of this: "You are a prisoner at present, and I believe all your life will remain so. Thanks to the milk-and-water softness of your former master! [...] The Squire is determined you shall never pass the reach of his disposal." (Godwin 2005: 323) Realising that the distribution of power in his relationship with Falkland will always remain unequal to his disadvantage, Caleb, once again, decides to risk breaking the bond, and let the secret out of the 'closet,' using it as the only instrument of power he still seems to possess: "Tremble! Tyrants have trembled, surrounded with whole armies of their Janissaries! [...] I will unfold a tale! - I will show to the world what thou art; and all the men that live shall confess my truth!" (Godwin 2005: 324/25) At this point, the narrative, having explored every detail of mental and physical concealment and containment, returns to the spatial image that triggered all the events of the story: the trunk containing Falkland's secret, the spatial 'closet' of his life that Caleb, by opening it, has had to share. It is telling that Caleb never actually sees nor learns what the trunk actually contains: "The contents of the fatal trunk, from which all my misfortunes originated, I have never been able to ascertain." (Godwin 2005: 326) The trunk's spatial 'reality' is elusive, invested with guesses, and never revealing all its 'truth.' It is space and metaphor at the same time.

The two endings Godwin wrote for the novel - the original and the published one - both, in their own way, show that Caleb's situation cannot be positively resolved. Determined again to reveal Falkland's secret in front of a magistrate, Caleb is confronted by Falkland, whose "appearance of a corpse" (Godwin 2005: 329) is the physical sign of his paranoid existence. The secret and its protection slowly kill him. From this moment, the two endings diverge.

In the published ending, the moment Caleb sees his former master in this state, he is reminded of the vital importance of their bond to himself, and of the danger he is putting it in:

"Shall I trample on a man thus dreadfully reduced? [...] I have reverenced him; he was worthy of reverence: I have loved him; he was endowed with qualities that partook of divine. From the first moment I saw him, I conceived the most ardent admiration. [...His] secret was a most painful burthen to me; [...] but I would have died a thousand deaths rather than betray it." (Godwin 2005: 330-32)

Caleb realises that, despite his own sufferings, all he has wanted, from the start, is to be close to Falkland, and to keep his secret. This alternative, however, as the reader is aware, was always already foreclosed by Falkland's inevitable paranoia, and Caleb's sense of 'honour' (he would not sign the contract). Caleb realises that 
he has broken the bond, and what follows is a last - and almost comical - mutual display of 'manly affection' between Falkland and Caleb: the latter praises Falkland's "affection and kindness" (Godwin 2005: 334), and Falkland is moved to declare "the greatness and elevation of [Caleb's] mind," and is impressed by his "artless and manly story" (Godwin 2005: 335). This 'manly' contest of mutual praise and self-accusation, however, cannot change the fact that the spell is broken: not only is the secret out (Caleb has spoken it once before), but Falkland has given up his position of social power over Caleb, and admits his guilt. The equilibrium of their ambiguous relationship could only exist in the unspoken and eroticised agreement of shared secrecy and their social inequality. As David Halperin aptly observes, "[w]ithin the horizons of the male world, [...] hierarchy [...] is hot" (Halperin 2002: 118).

The result of the loss of this equilibrium is disastrous for both characters: Falkland, one can assume, will die due to "the destruction of that for the sake of which alone I consented to exist" (Godwin 2005: 335) (i.e. his 'honour'); and Caleb realises that "it is now that [he is] truly miserable" (Godwin 2005: 336). Neither of the two men can go on living without the other. Falkland loses both his secret sharer and his good reputation; and Caleb loses his source of homosocial identification and power that has given meaning to his life: "I have now no character that I wish to vindicate." (Godwin 2005: 337)

The situation in the alternative, unpublished ending of the novel is similar for Caleb, but crucially different for Falkland. Here, Falkland does not forget his advantages as a social superior, and counters Caleb's accusations, foregrounding his own "uniformly benevolent and honourable life," and drawing attention to Caleb's alleged crimes as "first a thief; then a breaker of prisons; and last a consummate adept in every species of disguise" (Godwin 2005: 341), a subversive element in this homosocial society. Falkland succeeds: by upholding the social distance between himself and Caleb, and, again, using it to his advantage, he manages to finally decide the power struggle between himself and Caleb for himself. Caleb ends up defeated, "incarcerated in an 'apartment' with Jones (Gines) as his 'keeper"' (Godwin 2005: 342n). By finally confining Caleb to a 'closet' in the realm of his power, Falkland has removed the most immediate source of his paranoia. Though not destroying Caleb physically, he - with the help of Gines and another 'female helper' - drives him into a madness that erases all knowledge of the secret from Caleb's memory: "I should like to recollect something - [...] but it is all a BLANK!" (Godwin 2005: 345) Caleb now fully realises the terrible power of knowing and speaking, and how, due to the inherently political nature of speaking, choosing not to speak might sometimes seem the more peaceful alternative: "If I could once again be thoroughly myself, I would tell such tales! - Some folks are afraid of that, [...] and some folks said I disturbed them - and so, I believe they 
have given me something to quiet me. [...] It is wisest to be quiet, it seems $-[\ldots]$ True happiness lies in being like a stone.” (Godwin 2005: 346)

Caleb, in this version, is the female heroine again, albeit one that has failed: the master has his knowledge safely under control, the paranoid structure of his secret has not led to his undoing, and Caleb is reduced to a 'closeted' existence as 'the $\operatorname{mad}(w o) m a n$ in the attic,' the living reminder of the unstable character of masculinity depicted in Caleb Williams.

Eve Sedgwick lists Caleb Williams as a Gothic novel of the 'Schreber type,' arguing that these novels' paranoid homosocial structure shows that "paranoia is the psychosis that makes graphic the mechanisms of homophobia" (Sedgwick 1985: 91). I have demonstrated, however, that a mere sexualised reading of the novel cannot sufficiently account for its unique structure of masculine crisis that evolves both from the obsessive preoccupation with unliveable concepts of 'honourable' masculinity, and the creation of a paranoid structure that is the result of this obsession. 'Sodomitical' connotations and allusions - especially in the character of Falkland - are part of the novel's depiction of failing masculinities. These 'sexual' undertones, however, have not yet completely fused with the paranoid structure of the secret. I agree with Sedgwick's verdict that "through these novels a tradition of homophobic thematic was a force in the development of the Gothic" (Sedgwick 1985: 92). Homophobia is a theme in Caleb Williams, but it has not yet definitely and undeniably entered the 'closet.' Godwin's novel does, however, foreshadow a development that will finally merge the increasingly paranoid self-fashioning of 'masculinity' with the one discourse that becomes the greatest challenge for traditional notions of masculine gender: sexuality. Caleb Williams is a novel on the threshold, its male characters being caught in a homosocial world that is driven by paranoia, and that will increasingly have to position itself in a more and more rigorous dichotomy of 'sexual identities.' 



\section{The Contested Secret Room: Sensation Novels}

\section{Powerless Landlords: Wilkie Collins' The Woman in White}

Wilkie Collins' 1859/60 The Woman in White is generally considered to be one of the first novels that inaugurated the short-lived genre of sensation fiction. Domesticating the horrors of the Gothic, Collins portrays female characters who, threatened by a patriarchal system that affords them neither social nor financial security, cleverly subvert the power structures that oppress them. In The Woman in White, a text "riddled with sexual and gender anxieties" (Nemesvari 2006: 95), patriarchs of the home are exposed as weak and paranoid, losing control over domestic space, and the secrets contained therein. Collins questions Victorian assumptions about masculine activity and feminine passivity, and eventually has his narrative turn its back on the patriarchal domestic, shifting focus more and more towards liminal spaces, in which power relations, secrets, and identities are re-negotiated. Secrecy, indeed, dominates the novel: "The Woman in White is, at its very centre, in its margins, between the lines, and beyond its pages, obsessed with secrecy." (Bachman 2010: 75) The sensation novel in general, as Lyn Pykett remarks, "goes out of its way to foreground the interconnectedness of its use of secrecy as a narrative device (to capture and keep the attention of readers) and its exploration of secrecy as a broader cultural phenomenon" (Pykett 2011: 42). This multi-layered preoccupation with secrecy is inextricably linked, as I will argue here, to questions of gendered power relations and, in particular, masculine self-definition. Homosocial secrecy becomes a source of masculine paranoia, and the compulsive 'need to read' oneself and others according to the rules of heteronormativity. Collins, hence, in an ostensibly heteronormative plot, constructs masculinities that bear the paranoid markers of nineteenth century 'homosexual panic,' "which arises from the existence of just-about-to-be-exposed secrets that are essential to the sensation genre, but that in this narrative are always clustered around representations of improper masculinity" (Nemesvari 2006: 98).

The story is told from an array of different perspectives, with a focus on the novel's two main characters: Walter Hartright - whose telling name appears to 
make him the ideal masculine hero and perfect lover for Laura Fairlie - and Marian Halcombe, Laura's half-sister, confidante, and the novel's female heroine. Many critics have commented on the effect the confusing variety of narrative voices has on the novel's readers. As Philipp Erchinger observes, Collins creates

"a highly intriguing fabric of individual fictional discourses, managed, manipulated and lined up by an equally fictional editor, Walter Hartright, whose true motives and principles must, by virtue of their fictional character, necessarily remain secret and therefore, despite all his declarations to the contrary, fundamentally unreliable." (Erchinger 2008: 51)

What makes The Woman in White compelling, then, is less the suspense Collins creates before revealing the narrative's secrets, but the very impossibility of establishing one absolute fictional 'truth' about the events presented. The novel's readers have to form their own opinion, decide whom to trust, and which parts of the 'evidence' to believe in. As Mark M. Hennelly, Jr. puts it, "the novel [...] provides a blank universe pregnant with meaning which each reader must construct, or reconstruct, himself" (Hennelly 1998: 93). What Collins requires of his readers, then, is what Erchinger calls a "performative reading" (Erchinger 2008: 54), a reading that establishes one 'truth,' but can never be the truth. Collins, hence, plays with a narrative strategy that Henry James will later carry to prolific extremes: he exploits the 'paranoid reader's' tendency to compulsively look for coherent meaning, and to make sense of the world presented to them. Maria K. Bachman observes: "[F]rom the very first page of the novel, the reader enters a densely plotted labyrinth of secrecy from which there is no turning back because the concealment and disclosure of knowledge - the operating principle of secrecy - stimulates our curiosity, our inquisitiveness, our determined and unrelenting need to know." (Bachman 2010: 78)

Although Bachman expertly analyses the workings of secrecy in the novel, she does not address the gendered nature of these dynamics. Both the women and the men of Collins' fictional worlds have secrets, and Bachman rightly notes that " $[\mathrm{t}]$ he concealment of knowledge is a control mechanism, a perpetual, but always tenuous grasp for power" (Bachman 2010: 83). I would like to draw closer attention, however, to the ways in which these dynamics of power become crucially problematic as a constitutive element of masculine self-perception. Collins constructs the 'will to knowledge' Bachman describes as a means for his male characters to establish interpretative authority through their compulsive drive to 'read' the people around them according to their needs, and, more importantly, to be in control of the ways in which they themselves are being 'read' by others. This masculine excess in 'paranoid readings' is staged in domestic and liminal spaces that both 
enable to conceal, and threaten to reveal the men's secrets. The male 'paranoid reader' needs a public, and Walter Hartright has the biggest stage as the narrative's fictional editor, who performs his self-fashioning as non-paranoid male hero for his readership in a way that - ironically and inevitably - turns out to be a desperate attempt to be 'hailed' as the only stable man, and heterosexual saviour of the novel's female characters, but employs the same rhetorical techniques that constitute the masculine 'paranoid reader.'

\section{Degenerate Patriarchy: Limmeridge House}

After his encounter with Anne Catherick, the mysterious 'woman in white,' in the streets of London, Walter travels to Limmeridge House to take up a post as tutor to the house's young women, "a job [that] entails an emasculation that threatens his sense of male identity and gentlemanly privilege" (Nemesvari 2006: 98). From the start, Collins' portrayal of the house and its occupants questions established domestic power relations and gender stereotypes. Not only is the house built in the shifting, liminal environment of the coastal town of Carlisle (cf. Collins 2003: 3233), but it is also not its master who welcomes Walter at his arrival. Instead, Marian occupies the spatially and linguistically dominant position of confident manager of the house's affairs. This position corresponds with an extremely androgynous appearance: "The lady is ugly! [...] She had a large, firm, masculine mouth and jaw [...and was] altogether wanting in those feminine attractions of gentleness and pliability." (Collins 2003: 35) It is also Marian, not Mr Fairlie, who receives the family solicitor, Mr Gilmore, to settle the affairs for Laura's marriage to Sir Percival Glyde: "Miss Halcombe waited on the door steps until the fly drew up; and then advanced to shake hands with [Mr Gilmore]." (Collins 2003: 115) Walter himself is rather awed by this 'manly woman,' "almost repelled by the masculine form and the masculine look of [her] features" (Collins 2003: 35). Wanting - from the perspective of the male protagonist - a certain degree of femininity, Marian's deliberation and activity stand in stark positive contrast to the degeneration of the house's actual master.

Frederick Fairlie is not only "a single man" (Collins 2003: 37), and, hence, jeopardising the continuation of his lineage, but also "an invalid" of unspecifiable suffering: "[T]he doctors don't know what is the matter with him. [...] We all say it's on the nerves, and we none of us know what we mean when we say it." (Collins 2003: 37) What is more, Mr Fairlie is tucked away, as it were, in the most secluded, least representative, and most out-of-the-way part of his own house, down "a long second passage," up "a short flight of stairs," across "a small circular upper hall" (Collins 2003: 41), and behind two doors and two curtains. His room has the air of 
a closet in the sense of an early modern cabinet of curiosities, in which he keeps religious paintings, furniture from abroad, and other collectibles (cf. Collins 2003: 41). Even Mr Fairlie himself seems to be just another curiosity, an item to be put away in this room in which "the windows were concealed and [...t]he light [...] was deliciously soft, mysterious and subdued" (Collins 2003: 41). Although Walter calls him "the master of the house," this master lacks all signs of strength, virility, or even real life: "His beardless face was thin, worn, and transparently pale $[; \ldots]$ his hair was scanty[;...h]is feet were effeminately small, and were clad in buff-coloured silk stockings, and little womanish bronze-leather slippers." (Collins 2003: 42) Mr Fairlie is characterised as anything but a 'proper man:' He "seems to belong to an intermediate sex or gender. Combining an excess of sensibility and aesthetic overrefinement with the oversensitivity of the nervous modern subject, he is simultaneously overcivilised and degenerate." (Pykett 2006: 55) Fairlie represents "a foreign unmanliness that implies sexual perversity" (Nemesvari 2006: 100) and sterility. A weak and fading 'non-man,' evacuated of 'masculinity' and desire, Collins eliminates Mr Fairlie as a person of any 'actual' gender, and, hence, as a socially significant being: "[H]e had a frail, languidly-fretful, over-refined look - something singularly and unpleasantly delicate in its association with a man, and, at the same time, something which could not possibly have looked natural and appropriate if it had been transferred to the personal appearance of a woman." (Collins 2003: 42)

Mr Fairlie refuses to take on any responsibility concerning the running of the house, constantly referring to "the lamentable state of [his] health" (Collins 2003: 43). He explicitly gives up the power to make decisions in favour of the two women, thus willingly subverting his own position of patriarchal power: "I wish I felt strong enough to go into that part of the arrangement - but I don't. The ladies, who profit by your kind services, Mr. Hartright, must settle, and decide, and so on, for themselves." (Collins 2003: 47) On a more subtle note, the reference to his garden as a 'hortus conclusus' further associates him with a tradition of feminine virginity: "The garden was carefully walled in, all round[.., a] sacred seclusion." (Collins 2003: 46)

Mr Fairlie's garden, in fact, while serving to illustrate his own unwillingness to take action, increasingly becomes the space in which the other three characters meet and form bonds that undermine Mr Fairlie's theoretical authority. Here, Walter meets Laura for the first time, and falls in love with her (cf. Collins 2003: 5064), later learning that she has already been promised to Sir Percival; and it is also in the garden that Marian and Walter form a heterosocial bond over the curious case of the 'woman in white' (cf. Collins 2003: 50; 70). The private atmosphere of the garden enables Marian to make Walter understand that she is a woman who 'knows things,' and from whom it is hard to keep secrets: "I discovered your secret 
[that he loves Laura] - without help, or hint, mind, from any one else." (Collins 2003: 71) This woman is potentially dangerous to the male-patriarchal system of power over knowledge, both because she knows the men's secrets, and is eager to find them out, and because she refuses to position herself within the established system of a homosocial-heterosexual matrix. Instead, she makes herself unavailable as an object of heterosexual desire, and strives to establish a heterosocial bond with Walter, to act both as manager of the house's affairs, and in the interest of her thus befriended companion: "You are guilty of weakness. [...] If you had acted [...] less delicately and less modestly, I should have told you to leave the house. [...] Shake hands. [...] You must leave Limmeridge House, Mr Hartright, before more harm is done." (Collins 2003: 71-72) Ironically, putting herself in a more than conspicuous position as a woman, questioning Walter's own masculinity in making decisions for (and knowing so much about) him, Marian explicitly reminds him of his duty to manliness, aware of his dangerously self-compromising situation: "Don't shrink under it like a woman. Tear it out; trample it under foot like a man!" (Collins 2003: 73) Walter, however, refuses to adopt the kind of brutal, 'masculine' strength Marian seems to expect from him. Instead, he remains sentimentally attached to the garden's heterotopian spatiality he associates with his love for Laura: In the garden, "[I] took my farewell of the scenes which were so associated with the brief dreamtime of happiness and my love" (Collins 2003: 116), an escapist longing he takes even further into the liminal, "over the moor, and round the sandhills, down to the beach" (Collins 2003: 117).

The heterosocial bond between Marian and Walter eventually makes the latter complicit in Marian's subversion of the house's patriarchal power structures. He becomes her confidant and advisor: "You [Walter] are the only person in the house, or out of it, who can advise me. Mr. Fairlie, in his state of health [...] is not to be thought of. The clergyman is a good, weak man, who knows nothing out of the routine of his duties." (Collins 2003: 78) Faced with the failure of both secular and clerical patriarchy to deal with her and Laura's troubles, Marian looks to Walter, as her friend, for help. While, however, his love for Laura alludes to an accepted (heterosexual) path to domestic power, Walter's intimate intellectual (heterosocial) friendship with Marian puts him in a position of influence that contradicts the culturally sanctioned 'rules of the game' that are available to the novel's men.

It soon becomes obvious that heterosexual bonding is stagnant in Collins' story. Apart from Walter, all other principal male characters are depicted as decadent, effeminate, and ill - hence far from successfully putting their reproductive organs to use. When Anne Catherick, the mysterious 'woman in white,' warns Laura in a letter not to marry Sir Percival, her fear alludes, not least of all, to his lack of 'manliness:' '[H]is nose [was] straight and handsome and delicate enough to have done for a woman's. His hands the same. He was troubled for a time with a dry hacking 
cough." (Collins 2003: 80) Lacking virility and health, Sir Percival is hardly the ideal patriarch within a system that relies on its own reproductivity.

Although Walter's close association with women questions his position within a homosocial-heterosexual framework due to its emphatically heterosocial nature, it is this very association that makes him (for a while at least) the novel's only stable male character. His failure to buy into the structures of domestic patriarchy saves him from an economy of degeneracy that Collins portrays in his other male characters. Walter, in fact, repeatedly moves into liminal spaces that are associated with femininity (such as the garden), and that help him realise his own position within the novel's female-dominated world. When Marian leads him to Mrs Fairlie's grave in the churchyard, Walter feels a strong intuition that Laura's dead mother will be a key to the mystery of the 'woman in white' (cf. Collins 2003: 91); and it is, indeed, here that Walter encounters Anne Catherick (who is, in fact, Laura's half-sister) for the second time: "Under the wan wild evening light, that woman and I were met together again; a grave between us, the dead about us, the lonesome hills closing us round on every side." (Collins 2003: 96) In the liminal space of the churchyard, at the liminal time of twilight, mediated through Laura's dead mother (and Anne's 'substitute mother'), Walter gets the first hints that will help him solve the mystery surrounding the women. He also, however, puts himself in a compromising position: he both acknowledges that he is, in fact, only a messenger in the homosocial traffic of knowledge between women ("Miss Fairlie will keep your [Anne's] secret, and not let you come to any harm." [Collins 2003: 103]), and realises that, in meeting Anne, and helping her escape from the asylum at the very beginning of the story, he has actually discovered (and uncovered) part of a patriarchal secret, namely that Anne was locked away by Sir Percival in the first place ("A man had shut her up - and that man was Sir Percival Glyde." [Collins 2003: 105]). Walter, in a way, has helped Bluebeard's wife escape, thereby intruding on a powerful man's secret (Anne was locked away because Sir Percival assumes she knows the secret of his illegitimacy), without being made homosocial secret sharer.

Walter flouts the rules of patriarchal, male-homosocial bonding, and even helps subvert them, acknowledging his disregard for its inherently misogynist mechanisms: "I am incapable of harming [Anne] or any woman." (Collins 2003: 106) Anne, however, remains suspicious, unable to predict Walter's trustworthiness as a heterosocially interested friend: "[Y]ou know too much; I'm afraid you'll always frighten me now." (Collins 2003: 107) Walter's ambiguous moving beyond the rules of homsociality makes him conspicuous, even to those he is trying to help.

Laura, who has, so far, not been very present in the narrative, turns out to be the novel's embodiment of an 'ideal patriarchal femininity' which does not question the male monopoly on knowledge. She not only feels obliged to marry Sir Percival because it was her father's final wish, unquestioningly accepting the 
power of the (F)father ("I have broken my promise and forgotten my father's dying words. [...] I was guided by my father, [...] he knew what was best, [...] his hopes and wishes ought to be my hopes and wishes too." [Collins 2003: 163; 68]), but she also acknowledges that she, as a wife, does not have a right to secrecy: "[I will] tell Sir Percival Glyde the truth, [...] and [...] let him release me, if he will, not because I ask him, but because he knows all." (Collins 2003: 163) Marian, who is aware of the danger of such a blind acceptance of the economy of patriarchal knowledge structures that will leave women robbed of any power over knowledge themselves, warns Laura to "never lower yourself by making a confession to him. [...] He has not the shadow of a right to know." (Collins 2003: 164) Laura, however, has incorporated the laws of the (F)father: "I ought to deceive no one - least of all the man to whom my father gave me, and to whom I gave myself." (Collins 2003: 164) Collins here contrasts two versions of femininity that either confirm, or challenge a male-homosocial power that is based on a monopoly on knowledge to the exclusion of women.

He also, however, affords the two sisters a moment of female-homosocial complicity when Laura puts all the things that remind her of her love for Walter "in a drawer of her cabinet. She locked the drawer, and brought the key to [Marian]." (Collins 2003: 172) Symbolically creating a 'closet' of her own, in which she can keep the secret of her love, which she only shares with her sister, Laura, in a small way, does resist the tyranny of masculine omniscience. In making her sister literally the keeper of her secret ("Keep the key wherever you please - I shall never want it again.” [Collins 2003: 172]), she creates an actual and mental space her future husband will never have access to.

Strikingly, although Collins clearly portrays Mr Fairlie as a failing patriarch, and Marian as the person actually in charge at Limmeridge House, neither woman can escape the structural power the nominal master of the house still has over them. Although an inadequate man personally, the position patriarchal society provides Mr Fairlie with keeps the sisters from making decisions for themselves, and both express their resignation to this situation in their own way. Laura "consent[s] to whatever arrangement [her uncle] may think best," and even Marian cannot do anything but express her helpless anger: "I banged the door after me; and I hope I shattered Mr. Fairlie's nervous system for the rest of the day." (Collins 2003: 182) The house of patriarchy is still standing, and the women are its prisoners. In the course of the story, however, it will become clear that the inherently paranoid nature of the male-homosocial system of power portrayed here will eventually have to bend to the subversive forces represented by Marian and Walter. Marian is aware of her potential as a disturbing force in her sister's marriage, a force that irritates the boundaries of the established heterosexual-homosocial matrix: " $[\mathrm{N}] \mathrm{o}$ man tolerates a rival - not even a woman rival - in his wife's affections [...and] in 
the position of the chosen depository of his wife's closest secrets." (Collins 2003: 185) What makes Marian dangerous, then, for Sir Percival is both the female-homosocial bond she shares with Laura, an "attachment [...which] is presented as problematically erotic and possessive" (Nemesvari 2006: 104), and her potentially 'masculine' attitude as a rival in the triangular competition for influence on Laura. Emotionally, in fact, as Carolyn Dever remarks, "[t]he union of Laura and Marian is the novel's most fully realised 'marriage"' (Dever 2006: 114), and, hence, a real homosocial 'alternative' to the heterosexual bond between Laura and Percival. Collins, then, constructs a full reversal of the normative axes of desire, and contrasts a dysfunctional homosocial/heterosexual norm (Mr Fairlie-Sir Percival-Laura) with a heterosocial/homoemotional/-erotic option (Walter-Marian-Laura).

\section{Paranoid Masculinity: Blackwater Park}

Collins constructs Blackwater Park, “'the ancient and interesting seat' (as the county history obligingly informs [Marian]) 'of Sir Percival Glyde, Bart'” (Collins 2003: 196), as the Gothic architecture in which its master can stage his schemes, and in which the women living with this Victorian Bluebeard will have to enact the role of weak female victims. Stephen Bernstein emphasises the importance of the house's fictional architecture for an understanding of the characters' actions, and for any reading of the novel: "Collins is able to inscribe a highly concentrated, at times iconically allegorical, narrative into the very surroundings in which his characters function. The Park's status as a gothic setting enables such manipulation, simultaneously drawing on one of the larger generic narratives within which the novel is positioned." (Bernstein 1993: 291)

The house is, as Marian remarks, "the exact opposite of Limmeridge[...,] situated on a dead flat, [it] seems to be shut in - almost suffocated [...] by trees" (Collins 2003: 197). Just as out-of-the-way as Limmeridge House, Blackwater Park nevertheless lacks the open qualities of the Fairlies' seaside estate. Rather than a space of unsettling permeability, this is a prison, and a space that is unknown and mysterious, and, hence, uncontrollable to Marian: "I know nothing about the house, except that one wing of it is said to be five hundred years old." (Collins 2003: 197) This is a 'domesticated' Udolpho, a Bluebeard's castle: "Collins is able to put Blackwater Park firmly in line with his gothic precursors by sharing the earlier settings' accent on darkness and the problematics of vision." (Bernstein 1993: 293) Marian is painfully aware of the disadvantage of the gendered position this Gothic spatiality coerces her into: 
"If only I had the privileges of a man, I would order out Sir Percival's best horse instantly, and tear away on a night-gallop, eastward, to meet the rising sun. [...] Being, however, nothing but a woman, condemned to patience, propriety, and petticoats, for life, I must respect the housekeeper's opinions, and try to compose myself in some feeble and feminine way." (Collins 2003: 197-98)

The house itself, however, questions the position of dominance Sir Percival claims for himself, and foreshadows his ultimate defeat. Marian aptly observes that "[m] ost men show something of their dispositions in their own houses, which they have concealed elsewhere" (Collins 2003: 214). She describes the place as full of "dust and dirt," and "the half-ruined wing on the left" suggests nothing but "damp, darkness, and rats" (Collins 2003: 203). Part of the house is in a state of decay, and this fact cannot be concealed by the inhabitable right wing, which is "very elegantly furnished with the delightful modern luxuries. [...T]he rooms [...] all look pleasant to live in" (Collins 2003: 203). The house mirrors its master in that it tries to hide an ugly and decaying secret from the past (Sir Percival's illegitimacy) under a thin layer of representative cleanliness and respectability, "a mania for order and regularity" (Collins 2003: 214). As do many other fictional Gothic architectures from the eighteenth century onwards, Blackwater Park represents a modern concern with the public and the private, "demonstrating that gothic setting, ideologically charged in its effort to link the spheres of public and private, becomes a central narrative concern" (Bernstein 1993: 294). The question as to what can be contained in private and what can be (or has been) spoken in public, becomes vital for Sir Percival.

After Laura's arrival at Blackwater Park, the rivalry between Sir Percival and Marian over Laura - a variation of Sedgwick's male-female-male triangle of desire - surfaces once again when the sisters realise that Laura's marriage to Sir Percival threatens their homosocial bond: "I [Laura] would tell you everything, darling, about myself, [...] if my confidences could only end there. But they could not - they would lead me into confidences about my husband, too." (Collins 2003: 212) Aware, however, that the triangular arrangement affords her a certain sense of security, Laura is willing to try and make this house their (as opposed to Sir Percival's) home by "keep[ing] all [her] little treasures from Limmeridge here" (Collins 2003: 212). She also asks Marian to choose their homosocial over any potential heterosexual bond (“[P]romise you will never marry, and leave me. [...Y]ou are so much better off as a single woman.” [Collins 2003: 212]), thereby securing herself protection from a woman who, as long as she remains alone, can assume a position of 'masculine' strength more easily than in the socially scripted role of wife and mother. 
Blackwater Park has a tendency to make the women that move within its fictional architecture adhere to the rules of patriarchy to an extent they would not elsewhere. Laura becomes the meek and passive woman Sir Percival requires her to be, "sit[ting] for hours together without saying a word, [...] like a decent woman, [...] with the look of mute submissive inquiry [...] of a faithful dog" (Collins 2003: 216). What is more, Marian accepts this change in Laura as "a change for the better, seeing that it has transformed her into a civil, silent, unobtrusive woman, who is never in the way" (Collins 2003: 216), a kind of feminine behaviour Marian would certainly never choose for herself.

Count Fosco, on the other hand, Sir Percival's close friend, is immune to the house's patronising atmosphere. He is the novel's strangest character, evading any normative patterns, while certainly being the most powerful and influential of all of Collins' men. Marian perceives him as "a man who could tame anything. [...] The man has interested me, has attracted me, has forced me to like him." (Collins 2003: 217) Equipped with immense charisma, the Count's body does not mirror his character's inherent respectability: He is "immensely fat" (Collins 2003: 217), hence eliminated from a straightforward economy of physical desire. While he bears "a most remarkable likeness [...] of the Great Napoleon," and "the power of his eyes" awes Marian, he is not only foreign (Italian), and, hence, the "dangerous other that serves to define proper masculinity by being its opposite" (Nemesvari 2006: 96), but also displays an eclectic taste in animals, bringing with him "a cockatoo, two canary-birds, and a whole family of white mice" (Collins 2003: 21819), the latter being constantly attached to his body, making it seem disturbingly 'penetrable,' a discomfort Marian phrases as follows: "[T]he sight of [the mice], creeping about a man's body is, for some reason, not pleasant to me." (Collins 2003: 230) All this makes Fosco a contradictory and properly strange character, who resists any categorisation along the axes of genders or sexualities. His ability to "manage [Marian], as he manages his wife and Laura, [...] as he manages Sir Percival himself" (Collins 2003: 222), make him a force to be reckoned with, a man who is intensely aware of the mechanisms of power that dominate the society he lives in. Despite his "effeminate tastes and amusements" (Collins 2003: 222), he exerts an eery power over those around him. Always ahead of everyone else, he makes himself indispensible to both his friends and his enemies. His close homosocial relationship with Sir Percival also, however, further undermines the latter's self-definition as a virile, heterosexual man, which is already being significantly damaged by Percival's failure to assert a dominant position within the 'marriage triangle' of himself, Laura, and Marian: "Glyde's [own] foreign background, his intimate friendship with the Italian Fosco, his lack of intimacy with his English wife, and the extreme anxiety that he experiences, all suggest a looming same-sex scandal of the type that punctuated the nineteenth century." (Nemesvari 2006: 102) 
At Blackwater Park, the homosocial bond of secrecy between Fosco and Sir Percival is increasingly subverted by Marian, who begins to spy on the two men, an activity she initially scolds herself for: "[I]t was very wrong and very discreditable to listen - but where is the woman [...] who can regulate her actions by the abstract principle of honour." (Collins 2003: 225) Ostensibly criticising the weaknesses of her own sex, Marian also questions the validity of such 'abstract principles' as 'honour' - a principle that, as Godwin shows in Caleb Williams, often leads men to acts of mindless self-deprecation - and contrasts it with the practical wit of a woman who is ultimately daring enough not to let herself be hindered by the gendered restrictions of either (feminine) 'propriety' or (masculine) 'honour.'

"Eavesdropping - an improper activity on the border between inside and outside, private and public - figures transgression in the novel. An eavesdropper steals the secrets of private life and controls their dissemination in the public realm; by withholding or revealing people's secrets, the eavesdropper determines their social identity." (Gaylin 2001: 304)

It is Marian's social significance as eavesdropper that makes her, as a woman, particularly transgressive within the male-homosocial economy of information. As opposed to Laura, Marian is very much aware of the politics of knowledge that could afford her some advantage in this house, and she carefully chooses what to tell whom. When interrogated by Sir Percival about an incident with a stray dog, she "made [her] answers as short as [she] civilly could - for [she] had already determined to check the least approach to any exchanging of confidences between Count Fosco and [her]self" (Collins 2003: 239); and she is eager not to "appear in the very unenviable and very false character of a depositary of Sir Percival's secrets" (Collins 2003: 239). She wants neither of the men to assume any heterosocial bond between herself and either of them that could jeopardise her position in the household. Intruding upon the men's secrets, while keeping her willingness to do so carefully secret from them, Marian becomes a most effective Bluebeard's wife, one who is resourceful enough not to have her visits to the secret chamber discovered.

Actual power at Blackwater Park lies with Count Fosco. This becomes most obvious when Sir Percival tries to make Laura sign a document that would practically disinherit her in his favour. While, in this case, both Marian and Laura are aware of their right to knowing what the document Laura is supposed to sign contains ("I [Laura] ought surely to know what I am signing." [Collins 2003: 244] "[S] ign nothing, unless you have read it first." [Collins 2003: 245]), Sir Percival appears desperate, and not at all sure of himself: "[H]e looked more like a prisoner at the bar than a gentleman in his own house." (Collins 2003: 244) Fosco remains calm, 
and apologises for his friend's misconduct, thereby shaming him and questioning his position as master of his own house (cf. Collins 2003: 249). Marian is intuitively aware that Fosco is more dangerous to the women than Sir Percival could ever be: "Whatever you do, [Laura,] don't make an enemy of the Count!" (Collins 2003: 247) Sir Percival, in his bullying manner, is a predictable Gothic villain; Fosco, on the other hand, an opportunist who avoids clear-cut sides, genders, and politics, is an unpredictable element: "I [Marian] felt already, with a sense of inexpressible helplessness and humiliation, that it was either [the Count's] interest or his caprice to make sure of my continuing to reside at Blackwater Park." (Collins 2003: 249) Marian is willing to do all she can to spy on Sir Percival in order to help Laura, but Fosco remains a mystery to her: "How should I know his secrets?" (Collins 2003: 249) Fosco, then, is the novel's most efficient Bluebeard, firmly in control (at least for now) of the keys to his secrets.

When the house itself becomes too oppressive a space for the women to speak their minds, they retreat to the heterotopian space of the boathouse in the grounds of Blackwater Park (cf. Collins 2003: 257). Here, they try to rebuild their relationship that has been disrupted by Laura's keeping a secret from Marian: "That secret is the first I have ever had from you, love, and I am determined it shall be the last." (Collins 2003: 257) Strikingly, Laura's secret is a 'meta secret,' in that it contains her knowledge of having given up the last knowledge she had kept from Sir Percival, namely her love of Walter: "My only secret when I opened my heart to [Walter] at Limmeridge was a harmless secret, Marian. [...] The name was all I kept from him [Percival] - and he has discovered it." (Collins 2003: 260) Laura is aware of the disadvantageous position she has put herself in: not only has she given up the last private corner of her mind, but the information she has shared gives Sir Percival ultimate power over her: "Whenever he is angry with me now, he refers to what I acknowledged to him in your presence, with a sneer or a threat. I have no power to prevent him from putting his own horrible construction on the confidence I placed in him." (Collins 2003: 261) Knowledge is power, and Sir Percival, at this point in the novel, has all the advantage on his side.

At the same time, however, when Laura meets Anne in the same liminal space of the boathouse, Anne hints at her (alleged) knowledge of Sir Percival's secret, which would provide Laura with a powerful weapon against her husband: "If you [Laura] know his Secret, he will be afraid of you; he won't dare use you as he used me." (Collins 2003: 280) Although Anne does not reveal the secret (“[W]e are not alone - we are watched." [Collins 2003: 281]) - she does, in fact, not know its content - she does inform Laura that Mrs Catherick knows it too (She "has wasted under the Secret half her lifetime" [Collins 2003: 281].). It has become clear, at this point in the narrative, that Sir Percival is threatened by a secret from his past (his illegitimacy), the knowledge of which has (apparently) been shared among women, 
and is in danger of being shared more widely. This community of women (all, as we will learn towards the end of the novel, related) is beginning to discover the means to undo their oppressive Bluebeard by finding out his secret.

Failing to get at Laura's money, Sir Percival becomes more and more of a Gothic villain, keeping his wife a prisoner in his house: "Am I [Marian] to understand [...] that your wife's room is a prison, and that your housemaid is the gaoler who keeps it?" (Collins 2003: 293) Although this situation is relieved by the Count, who, once again, takes the women's side, and undermines Sir Percival's authority in his own house, it becomes increasingly clear that Sir Percival's real source of weakness is his paranoid constitution. Laura's potential for secrecy is a constant source of worry for him, and drives him into more and more extreme states of mind. Although Laura insists that she "could conceal nothing," Sir Percival suspects secrecy where there is none: "I mean to have the rest of you, [...] you know more than you choose to tell." (Collins 2003: 299) Scared that his secret might be discovered, he can never be sure that he is in control of all knowledge that is passed around him. Knowing the powerful dynamics of homosocial intimacy, he is especially concerned about Laura's bond with her half-sister: "There shall be no more plotting and whispering between you." (Collins 2003: 300) Marian, although not knowing the content of the secret yet, is aware of this Bluebeard's self-consuming paranoia: "He is mad - mad with the terrors of a guilty conscience. [...Y] ou [Laura] were on the brink of discovering a secret, $[\ldots]$ and he thinks you have discovered it." (Collins 2003: 300)

When the two women feel increasingly threatened by their situation, and an appeal to patriarchal authority (the Law, Mr Fairlie) seems either impossible or futile, Marian decides to take advantage of her intuition of Sir Percival's weakness, and to overhear him and Count Fosco plotting in the library, the domestic centre of the male-homosocial community of letters. Bending the house's architecture to her will to knowledge, Marian climbs onto the roof in the cold rain to spy on the two men's homosocial exchange of information. In this conversation, the Count both claims every real authority in the house for himself ("Thank your lucky star [...] that you have me in the house, to undo the harm, as fast as you do it. [...Y] ou leave [all direction], for the future, in my hands only." [Collins 2003: 324-25]), and acknowledges the potentially dangerous nature of Marian's gender-bending behaviour ("[S]he has the foresight and the resolution of a man." [Collins 2003: 324]). While Sir Percival is thus deprived of power, Marian also learns part of his secret, namely that he is hugely indebted, and that Count Fosco suggests paying these debts by faking Laura's death. What is more, Fosco is not only aware that Sir Percival keeps the greater part of his secret (that his title is illegitimate) even from him, but he refuses to become his secret sharer, knowing that too much knowledge could compromise his detached position: "You have a secret from me, Percival. 
[...] Say as little as possible [...] in my presence, of the Secret." (Collins 2003: 328; 30)

At the same time, Sir Percival goes increasingly mad because he knows that his secret is not safe: Both (he assumes) Anne Catherick and her mother know that the claim to his title is not legitimate. Fosco comments on the precariousness of this leaking of knowledge out of the realm of the male-homosocial community: "Two women in possession of your private mind - bad, bad, bad, my friend!" (Collins 2003: 330) Knowing that Laura has been in touch with Anne, Sir Percival naturally assumes she knows his secret too - although she does not: "Who can read the letter she hid in the sand, and not see that my wife is in possession of the secret, deny it as she may?" (Collins 2003: 330) Although confident that he can manage Mrs Catherick, the awareness that his secret is now known to three women makes Sir Percival increasingly paranoid.

Once again, Collins contrasts this paranoia with a heterosocial alternative. Having managed to exchange the identities of Laura and Anne, Count Fosco reads Marian's diary - which forms that part of the narrative told from her point of view - thus knowing all her secrets and leaving her no advantage. Fosco, hence, in a movement of what Elizabeth Anderman aptly calls "narrative rape" (Anderman 2009: 85), temporarily reclaims (masculine) narrative authority, and puts Marian back in her 'proper place' as a both physically and epistemologically 'penetrable' woman. He does, however, acknowledge her clever sense of a politics of knowledge, seeing something of an equal in her: "Admirable woman! [...S]ublime creature. [...] I lament afresh the cruel necessity which sets our interests at variance, and opposes us to each other." (Collins 2003: 336; 37) In a way, then, Fosco is Marian's ideal suitor. Far from appreciating her heterosexually, though, he has a heterosocial fantasy about her, which stands out as remarkably more satisfying for both parties than the normative, homosocial relationship between Fosco and Percival, in which the latter can never meet patriarchal-homosocial expectations of mutual support. Percival causes Fosco inconvenience; Marian would be his equal.

\section{Liminal Spaces: The Search for the Secret}

The end of the novel's second part foregrounds its preoccupation with questions of truth. Told from a confusing range of perspectives, this episode's climax is an epitaph entitled "4. The Narrative of the Tombstone" (Collins 2003: 405), which posits the 'truth' of Laura's death. As the reader finds out in the end, however, this physical 'proof' only forms part of a cleverly constructed narrative, fashioned by Count Fosco. Aware of the power of his and Sir Percival's discursive voices, he tells a 'truth' that both takes advantage of Anne's natural death (who thus ceases 
to be a danger to Sir Percival), and robs Laura and her friends of any believable voice of their own by giving Laura the identity of 'mad' (and, hence, not credible) Anne. Laura, confined to the madhouse, literally loses her voice and memory, 'accepting,' as it were, Fosco's powerful rhetorical move, which equals her identity with Anne's. Neither any of the characters, nor Collins' reader can now say for sure whether Laura really is herself or Anne, which woman has died and which survived. Instead, Collins presents us with two men struggling for narrative authority and the claim to their 'truth:' Fosco asserts that the woman in the madhouse is Anne, whereas Walter claims her to be Laura. While the space of the graveyard is the centre and anchor of Count Fosco's 'truth,' it is also the space in which Walter and Laura are reunited and start to plot against Percival and Fosco: "[T] woman had possession of me, body and soul. [...] We stood face to face, with the tombstone between us. [...] Laura, Lady Glyde, was standing by the inscription, and was looking at me over the grave." (Collins 2003: 410-11) The heterotopian space of the graveyard affords both narratives to exist simultaneously: that of Laura's death, and that of her survival. As in the scene described above, Walter, again, begins to claim agency in the presence of a community of women, bound together beyond death by family ties and their actions: Laura, her half-sister Anne, and Anne's mother.

Moving into the relative anonymity of "a populous and a poor neighbourhood in London" (Collins 2003: 412), Walter becomes part of the family of women he tries to protect: Laura and Marian "are described as my sisters" (Collins 2003: 412). In the liminal "house-forest of London" (Collins 2003: 412), the three of them start a fight with Sir Percival and Count Fosco over whose narrative is more powerful and more effective. Fosco tries to undermine the group by warning Mr Fairlie of 'Anne's' "assuming the character of [Sir Percival's] deceased wife" (Collins 2003: 417). Having taken Laura into the asylum from which Anne had escaped, Fosco sees to it that she gets Anne's clothes put on, thus 'turning her into' Anne: "Look at your own name on your clothes." (Collins 2003: 427) Taking surface for content, and accepting the striking resemblance between the two women as identity, no-one believes 'mad Anne' that she is actually Laura, not even her uncle: "Mr. Fairlie declared, in the most positive terms, that he did not recognise the woman who had been brought into his room." (Collins 2003: 428) Again, the 'pillars of society' fail to see more than what they are led to think they 'know.' When Walter appeals to a lawyer to help them in their cause, the latter declares it as lost because of the 'known facts:' "her aunt's testimony, [...] the testimony of the medical certificate, [...] the fact of the funeral, [...] the inscription on the tomb" (Collins 2003: 441). He insists several times that "it is known" (Collins 2003: 441) that things happened a certain way. Having this definite declaration of 'knowledge' stand in stark contrast with what the reader, whose sympathies tend to lie with Walter, be- 
lieves to be 'true,' Collins questions the very process of epistemology, and exposes the way the dominant discourse shapes 'knowledge of the truth.' Laura's physical 'performance' despite herself (wearing Anne's clothes) counts more than Walter's contrary account; and to the reader, neither 'fiction' (that the woman is either Laura or Anne) becomes graspable as an unquestionable 'truth.'

Ironically, then, Fosco constructs Laura as the performer that she actually becomes out of necessity, only making the very role unavailable to her that we assume to be her one 'real' performance: that of her own identity. In doing so, he not only denies the silenced woman access to the personality and position associated with 'Laura, Lady Glyde,' but also deprives her spatially of the place associated with them: her home, which becomes "the place of all others that was now most dangerous to her" (Collins 2003: 430). Strikingly, however, by the very act of casting her out into the liminal non-place of London, in which "all traces of [Laura and her friends] might be most speedily and most surely effaced" (Collins 2003: 430), Fosco and Percival provide Walter, Laura, and Marian with the very starting point from which they can act their way towards revenge, outside the rules of upper(-middle)-class domesticity.

This situation also affords Walter the means to assume the role of protector for the two women, allowing him to perform a kind of virile masculinity he has so far been denied: "All I have done to-day, is to ask another man to act for me. I count from to-morrow[..., b]ecause to-morrow I mean to act for myself." (Collins 2003: 449) He begins to control the women's spatial movements, acting as the domestic patriarch he has not had the chance to be: "[I]n my absence from home, [Laura and Marian] should let no one into their rooms on any pretence whatever." (Collins 2003: 432) Marian, at the same time, gives way to Walter's performance, and opts for an unusually 'feminine' domestic role for herself: "The house-work [...] was taken on the first day [...] by Marian. [...] 'What a woman's hands are fit for, [...] early and late, these hands of mine shall do."' (Collins 2003: 432-33) This performance of the nuclear family (father Walter, mother Marian, sister/child Laura) is enabled by the isolated nature of their life together, both spatially and socially: "[W]e three were as completely isolated in our place of concealment, as if the house we lived in had been a desert island, and the great network of streets and the thousands of our fellow creatures all round us the waters of an illimitable sea." (Collins 2003: 433) Count Fosco assumes this to be a space of potential oblivion, and accepts Laura's being safely 'closeted' away there: "The storms of life pass harmless over the valley of Seclusion - dwell, dear lady [Marian], in the valley. [...T] he fair companion of your retreat shall not be pursued." (Collins 2003: 448)

Fosco, however, underestimates the little 'family out of necessity's' willingness to take advantage of their relatively anonymous existence, and use their knowledge of Sir Percival's secret and his paranoia as a weapon against him: "Mar- 
ian! There is a weak place we both know of in Sir Percival's life[...:] the Secret. It is our only sure hold on him." (Collins 2003: 450) Their challenge, then, is to turn Mrs Catherick, who knows the secret, from Bluebeard's female helper into their confidante. One of the weak spots of Percival's patriarchal secret structure, then, is its one heterosocial element: the fact that the content of the secret has leaked out of the male-homosocial system. The danger can only be contained by threatening and isolating the female secret sharer: "[I]t was Sir Percival's interest to keep [Mrs Catherick] at Welmingham, because her character in that place was certain to isolate her from all communication with female neighbours." (Collins 2003: 471) This Sir Percival has achieved by forcing her into the very paranoid patriarchal economy of 'reputation' and 'honour' which he himself represents: knowing that she got pregnant with Anne while still unmarried, a fact which potentially "compromised her reputation" (Collins 2003: 472), Sir Percival blackmails her into complying with his wishes.

The paranoid structure of Sir Percival's 'closet' soon turns out to have had him jump to false conclusions. When Walter learns about Mrs Catherick's having (allegedly) shared Sir Percival's secret with her mentally ill daughter, it becomes apparent that, in fact, the latter knew no more than the fact of the existence of a potentially compromising secret on Sir Percival's part: "[I]t was perfectly in character with Anne's mental affliction that she should assume an absolute knowledge of the Secret on no better grounds than vague suspicion." (Collins 2003: 475) Sir Percival, nevertheless, reacts according to his paranoid disposition and has to assume the worst - namely Anne's absolute knowledge of his secret - and shuts her away in an asylum.

The key to Sir Percival's secret is to be found in "the vestry of the church" (Collins 2003: 490), the physical space of the very institution that sustains the patriarchal system of power he claims to be part of. The character of Old Welmingham church as a Gothic 'closet' is strongly highlighted in Walter's description of the "ancient, weather-beaten building" (Collins 2003: 495), the vestry of which is protected by "a perverse lock, [...] big enough for a prison door" (Collins 2003: 497). The vestry itself, in which Walter hopes to find the marriage register informing him of Sir Percival's family, is "a dim, mouldy, melancholy old room" (Collins 2003: 497). The analogy of vestry and prison, and the parish clerk calling the place “a lost corner" twice (Collins 2003: 498; 99), make this an abandoned Bluebeard's castle, the secret recess of patriarchal clerical authority, in which Sir Percival's secret is 'outsourced,' as it were, to a male-homosocial space outside the domestic, a forgotten room, which, nevertheless, is unpredictable as a hiding place: Walter is "struck by the insecurity of the place in which the [marriage] register was kept" (Collins 2003: 499). The 'house of patriarchy,' it appears, is not safe from intrusion 
any more. It is ancient, dilapidating, and has been moved to the margins, to a 'lost corner,' where it can be accessed at will.

When Sir Percival's secret is finally revealed, the power of knowledge, once again, becomes apparent. Although Sir Percival has managed to forge an entry about his parents in the register, Walter suspects there is something wrong and finds proof of forgery in a duplicate. At this point, almost at the end of the story, Sir Percival's secret is out: "[H]e was not Sir Percival Glyde at all, [...] he had no more claim to the baronetcy and to Blackwater Park than the poorest labourer who worked on the estate." (Collins 2003: 510) Walter, predictably, is aware of the immense power this knowledge now affords him over his opponent: "The disclosure of that secret [...] would deprive him, at one blow, of the name, the rank, the estate, the whole social existence that he had usurped. This was the Secret, and it was mine!" (Collins 2003: 510) Ironically, it is not Walter's word that ultimately destroys Sir Percival, but the latter's own paranoia. Afraid that Walter might discover his forgery, Sir Percival enters his 'closet,' the vestry, locks himself inside, and accidentally sets it on fire: "[T] here was another, and a last, grating turn of the key in the lock. [...] 'He is doomed and dead. He has hampered the lock."' (Collins 2003: 515) Simultaneously attempting to destroy the physical manifestation of his secret, and literally making his own body a prisoner of its self-destructive power, Sir Percival dies in the flames. What kills him, in the end, is the paranoia triggered by the secret that was the foundation of his power. Patriarchy, then, in Collins' fictional world, has a localisable centre of power: the register of legitimacy. The 'closet' it is kept in, however, is institutionalised, and lies out of reach of the individual male empowered by it. Masculine paranoia, hence, is globalised, and raised, as it were, from the private to the public cultural experience.

After Sir Percival's death, Mrs Catherick confesses her own secret to Walter. She was indeed 'Bluebeard's female helper' in that she got him literal access to the 'closet' he could not penetrate on his own: she got him "the key of the vestry, and the key of the press inside it" (Collins 2003: 530). Attempting to take advantage of the heterosocial potential of this situation, Mrs Catherick insists on Sir Percival's sharing his secret with her: "All the conditions I insisted on were that he should take me into his confidence and tell me everything. [...] I was determined to have all the truth - and I believe I got it." (Collins 2003: 530) Collins emphasises the power of knowledge about a secret, as opposed to knowledge of the secret's content itself, a power efficient enough to trigger Sir Percival's paranoia: Anne "knew that there was a Secret - she knew who was connected with it - she knew who would suffer by its being known - and, beyond that, [...] she never to her dying day knew more" (Collins 2003: 538). A rhetoric of secrecy, then, is powerful regardless of its content, and makes Bluebeard blackmailable. 
The last male character to be dealt with is Count Fosco, who turns out to be a spy, and, hence, a professional manager of information. While Collins constructs him as the one male character apparently immune to questions of gendered crises (but whose masculine gender is more than questionable), he ultimately fails due to the same mechanisms that ended Sir Percival's life. Following the Count to another heterotopian environment, the opera, a place inherently questioning and laying open the roles we play in life, Walter's friend Pesca scares the Count into an abrupt escape. Learning that the Count and Pesca - both Italian, both foreign, both potentially 'other' - are entangled in the homosocial, secret workings of one of "the political Societies" (Collins 2003: 574), and that the Count has betrayed "the Brotherhood" (Collins 2003: 578), Walter is informed that speaking the society's secrets means certain death. Ironically, Pesca nevertheless does not hesitate to share a secret with Walter, who, in turn, however, refuses to inform the reader of what he now knows: "My first and last concealments from the reader are those which caution renders absolutely necessary in this portion of the narrative." (Collins 2003: 574)

In the last section of his novel, Collins, obviously ridiculing the workings of secret societies, denies all of his male characters freedom from the self-destructive nature of the male-homosocial system of secrecy politics. Pesca, acknowledging that he himself cannot escape being a secret sharer ("I must remain in [the Society] now - it has got me." [Collins 2003: 576]), and although he has already shared some secret with Walter, makes the danger of such secrecy explicit: "Tell me nothing; keep me out of the secret of your thoughts. [...W]hatever you discover, whatever you do, tell me nothing!" (Collins 2003: 577) Strikingly, the final confrontation between Walter and Fosco takes place inside the Count's house, making his privacy more public to Walter and the reader than at any other point in the narrative. In an elaborate play of locking and unlocking rooms and drawers, the two men negotiate their terms. Collins cleverly constructs the situation such that the violence and danger both men are in is only ever evoked by references to knowledge that might be used as a weapon. What keeps Fosco from killing Walter is the simple knowledge that if Walter dies, Pesca will make the Count's betrayal public: "Your letter is received. If I [Pesca] don't hear from you [Walter] before the time you mention, I will break the seal when the clock strikes." (Collins 2003: 587) Knowledge, here, really is more powerful than physical violence. Collins, hence, portrays the homosocial community of men embodied by 'the Brotherhood' as infused with paranoia, aptly depicting the mechanisms of nineteenth-century 'homosexual panic' as described by Eve Sedgwick. As Richard Nemesvari puts it,

“Collins' text obsessively explores the threat posed by improper masculinities and their resulting, illicit, homosocial bonds, which are presented as under- 
mining not only proper personal relationships but also the very fabric of social stability. [...T] he Brotherhood, with its exclusively male membership that must remain secret and that creates a bond that marks the individual in a way that can never be erased, is an encoded representation and encapsulation of all the illicit homosocial and queer heterosexual relationships that have permeated the text." (Nemesvari 2006: 95; 106)

In the end, all principal male characters, apart from Walter, are dead, and all have failed because of their weaknesses as men: Sir Percival dies from his paranoia; Count Fosco is killed by the very secret society that was the homosocial foundation of his power and influence; and Mr Fairlie is simply too weak to survive. Laura and Walter inherit Limmeridge House, and thus the story ends in the domestic setting it started off in. The triangle consisting of Walter, Marian, and Laura stays intact, but it remains unclear how Walter can position himself within it. He acknowledges that Marian, the 'masculine woman,' "was the good angel of our lives" (Collins 2003: 627), and the driving force behind most of his actions. His son will be "one of the landed gentry of England" (Collins 2003: 626), continuing the patriarchal system of power. Far from being "victorious" (Nemesvari 2006: 107), however, as Nemesvari would have it, Walter's own role remains vague: inheriting the house through his wife, relying on Marian to push him to become active, and failing to inscribe himself into the self-destructive, but normative mechanisms of secretive masculinity, he has to establish a 'masculine' role for himself which re-negotiates traditional gender roles. As the novel's only middle-class male character, however, he is surprisingly successful, in that, as Rachel Ablow demonstrates, he ensures for himself a lucrative position as husband to a wealthy heiress by convincing others of her identity as Laura Glyde on no other grounds than his feelings for her: The novel offers "a fantasy of male, middle-class identity [...] that, unlike those offered in later sensation novels, revolves around the power of the middle-class man to define himself in highly profitable yet ideologically unproblematic ways" (Ablow 2003: 160). The alternative Collins offers to paranoid masculinity in The Woman in White, then, has its power rest on a convincing heterosocial fiction of sympathy with, as opposed to oppression of, women. It is quite obvious, though, that this fiction objectifies Laura just as much as any homosocial-secretive fiction of male supremacy would: Walter's “identity is produced less in relation to [Laura...] than in relation to what he says about himself in relation to her" (Ablow 2003: 169). While Walter's is the only masculinity that Collins portrays as sustainable, his gendered self-definition remains rooted within the very misogynistic discourses of male-homosocial patriarchy it claims to free itself from. After all, "[a]lthough it seems Marian and Walter contribute equally to solving the mystery, Walter ultimately controls what is told to whom" (Gaylin 2001: 305). 
What is more, although ostensibly rejecting and escaping from the paranoid mechanisms that destroy Sir Percival and Count Fosco, setting himself apart from their aristocratic 'degeneracy' as a new kind of bourgeois gentleman, Walter is nevertheless a 'paranoid reader,' in that he must constantly read Laura and her story in a way that will confirm his right to a position as wealthy domestic patriarch. His compulsive need to construct a coherent narrative from fragments, as Diane Elam argues, "replicates male phallic desire and attempts to possess woman as truth by narrating, by inscribing, by confining her figure as presence" (Elam 1993: 55), a desire Collins denies fulfilment. This concern with the paranoid search for meaning via the bodies of women is, as demonstrated above, mirrored on a meta-level in Collin's construction of the novel as a narrative of multiple perspectives, in which the 'truth' becomes a matter of discursive power and strategy, rather than any kind of 'objectivity.' Ann Gaylin even argues that novel reading itself is a gendered activity, in that "[t]he novel [...] represents a space of female narrative activity and mobility which eventually is contained and enclosed in reassuring, conventional, patriarchal structures [...] that confirm the normative gender ideology of the novel's conventional readers" (Gaylin 2001: 305). Following Gaylin's line of argument, Collins' novel is conventional in its portrayal of a male character who ultimately succeeds in asserting his right to an authoritative reading of the narrated events, only, however, making his story his own by including frequent "omissions, concealments and editing" (Pykett 2011: 43), creating a net of "narrative secrets' that return him to the 'reading gaol' of patriarchal masculinity. It is only in his later novel No Name that Collins will create the possibility of a real escape from this economy of male paranoia and compulsive will to supremacy on a level of character.

On the other hand, as D. A. Miller argues in his influential 1986 reading of Collins' novel, the activity of reading as a search for meaning in sensation fiction as such is inextricably linked with 'feminine' hysteria: "[T] he novel makes nervousness a metonymy for reading, its cause or effect. [...This] association [...] is complicated - not to say troubled - by its coincident, no less insistent or regular association with femininity." (Miller 1986: 110) Elizabeth Anderman makes a similar point in diagnosing the narrative style of Collins' novel as triggering "a kind of reading hysteria" (Anderman 2009: 79) in its readers. As 'paranoid readers' within a text that calls for being read 'hysterically,' Collins' male characters (and his male readers) are all prone to experience a feminisation that turns out to form an inherent part of their patriarchal masculine self-definition. 'Woman,' hence, in The Woman in White, is the 'other' that the men both find within themselves, and must, consequently, struggle to emphatically set themselves apart from; and from this struggle, not even Walter - or Walter least of all - as the narrative's meaning-making 'editor' is exempt: "His reading example demonstrates the hysteria of 
reading.” (Anderman 2009: 81) As M. Kellen Williams puts it, Walter's narrative's objective is "to inscribe, by establishing the difference between two women [Laura and Anne], the difference of woman, Woman's Difference[..., the recognizably real, material difference between having or not having a phallus" (Williams 1998: 92). The characters' misogyny, then, is both a fear of "male nervousness [through] female contagion" (Miller 1986: 110) - and, in extension, a nineteenth century homophobia that relies heavily on discourses of effeminacy - and a self-conscious awareness that the masculine-paranoid need to 'read' oneself and others bears at its core exactly this problem of androgyny - the problem, as it were, of where the phallus resides, of whether or not men's bodies succeed in being impenetrable. On a meta-level, then, The Woman in White does question the patriarchal urge for an authoritative reading and an epistemological (phallic) monopoly: its structure defies any definite conclusion and absolute truths; it is 'penetrable,' and, as such, foreshadows the kind of 'queer rhetoric' we will encounter in Henry James' writing, which celebrates the 'androgynously' ambiguous nature of genders and sexualities that cannot (or will not) speak their names.

\section{Performing Subversion: Wilkie Collins' No Name}

Nothing is as it 'should be' in Collins' 1862 novel No Name. Patriarchs fail to exert power over a space that is being increasingly invaded and subverted by female characters who understand that theirs is a society in which, while it is crucially important to know who you are (socially, economically, culturally), you can break down the barriers that society imposes by knowing how to play a role - in terms of gender, social rank, and personal identity itself. In No Name, "the natural itself is revealed to be socially shaped" (Taylor 1988: 135). Collins, in his "fictional critique of dominant modes of gender politics" (David 1998: 136) - a novel that is not coincidentally divided into 'scenes' - exposes "the means by which a social identity is constructed, and, equally, how it may be borrowed, invented, dismantled or buried" (Ford 2004: ix). More specifically, he portrays "an identity crisis plaguing Victorian men" (Kucich 2006: 125), who have forgotten how to rule the (domestic) world, and who are confronted with women who see that patriarchal masculinity, built on a politics of secrecy, is crumbling, leaving its failed men effeminate, fooled, or dead, allowing women to occupy the emerging vacuum. No Name, which is, like a lot of Collins' fiction, full of "disturbingly cross-gendered androgynous male and female figures" (Taylor 2006: 2), is not only a novel about "the cultural construction of femininity outside and inside the family" (Taylor 1988: 132), but about the arbitrary nature of social gender roles in general, and dysfunctional, patriarchal masculinities in particular. 
The performative nature of gender and social identities in No Name is, as Kylee-Anne Hingston observes, an extremely physical business: "Managing one's identity and body preoccupies every character[..., and] stable identities and healthy bodies prove to be illusionary." (Hingston 2012: 118) Identity is enacted through malleable bodies within an intricate spatiality of the domestic and the outdoors that places bodies in relation to each other. These spaces turn out to be just as unstable, subversive, and enabling as the characters' bodies themselves.

In his 1862 preface to the novel, Collins points out that "[ $\mathrm{t}]$ he only Secret contained in this book, is revealed midway in the first volume" (Collins 2004: xxvii). Nevertheless, the management of information, and its spatial concealment and disclosure are the driving forces at the centre of the narrative's gendered conflict. While, in many other specimen of the sensation novel, the reader is asked to participate in and witness the uncovering of a dark secret, here, we are made secret sharers, shifting the emphasis from a 'paranoid reading' to an experience of the power of knowing, the effect of which is an identification with the - ultimately disciplined - heroine: “[T]he reader's investment lies with the transgressor, the plotter, and not the detective." (Jones 2000: 198)

\section{The Idealised Patriarchal Home: Combe-Raven}

The story takes its reader to various domestic settings, the first of which is Combe-Raven, the idealised Victorian home of the Vanstone family, a scene which Sundeep Bisla aptly describes as the story's “introductory parody of the domestic novel" (Bisla 2010: 2). Combe-Raven is marked as a sight of Gothic secrecy: "Let the house reveal its own secrets." (Collins 2004: 3) Although Mr Vanstone, a Bluebeard with a secret from his past, is nominally "the master of the house" (Collins 2004: 4), the governess Miss Garth seems to be in charge: She "had hitherto held the position of a high authority on all domestic questions" (Collins 2004: 73). Miss Garth's "masculine readiness and decision of movement" and "air of habitual authority" (Collins 2004: 5) make her the novel's first gender-ambivalent female character. Similarly, Magdalen, the Vanstones' younger daughter, and the novel's protagonist, is also immediately characterised as something of a 'queer fish:' She displays "no recognizable resemblance to either of her parents," and combines "strongly-opposed characteristics" in a "strangely constituted organisation" (Collins 2004: 9). Although feminine in appearance, Magdalen is a strange, 'ungirly' girl. Mr Vanstone comments on both his daughter's, and his housekeeper's non-conformity: "If you're all rakes, Miss Garth, the sexes are turned topsy-turvy with a vengeance; and the men will have nothing left for it, but to stop at home and darn the stockings." (Collins 2004: 10) Although a light-hearted comment at this 
point, Mr Vanstone, alluding to Pope's famous line "Men some to Bus'ness, some to Pleasure take; / But ev'ry Woman is at heart a Rake" (Pope 2006: 215-216), aptly summarises the threat that lies at the heart of the novel: that women might not be what they seem, and could subvert established patriarchal norms and gender roles.

What is deviant about Magdalen is the very fact that she fashions her own (gender and social) identity, ignoring established ideals and roles, and crossing boundaries of what is 'proper' for women, and for men. The novel's first part mainly serves to introduce two of her most important characteristics: her refusal to blindly obey the rules of patriarchy, and her uncanny talent as an actress. Not only does Magdalen literally have access to all her father's keys - the symbol of patriarchal control over domestic space - but she also, as if it were a second nature, switches from one role to the next, regularly "assuming the daughter's" (Collins 2004: 12), making no distinction between acting out 'fictitious' or 'real' parts. "Magdalen's various impersonations [...] serve to suggest that both social and gender roles are forms of impersonation or masquerade.” (Pykett 2006: 60)

Magdalen's talent as a performer is repeatedly emphasised throughout the first scene. At the 'private theatricals' at Evergreen Lodge, the house of a nearby family, Magdalen, enthusiastic to take part, and convinced that she "could act every character in the play" (Collins 2004: 34), fully realises her own performative potential that will serve her well later, but that others perceive as threatening. It quickly becomes apparent that what is presented to the reader here is not a stage within a domestic space, but domestic space as stage: the drawing-room is "to be laid waste for a stage and a theatre[..., ] creating a dramatic world out of domestic chaos" (Collins 2004: 35). Life is chaos, the narrative implies, and only by performing social roles do we create order. Our being social exists only insofar as we act out our assigned roles: hence, the master and mistress of Evergreen Lodge are only "the nominal master and mistress of the house" (Collins 2004: 35). When Magdalen is finally on stage, her "rare faculty of dramatic impersonation" (Collins 2004: 48) astonishes everyone in the audience.

The second theme that dominates the novel's first part is the destructive nature of patriarchal secrecy. The Vanstone family and their household are threatened by a secret from Mr Vanstone's past: he and his wife never got married, because he already has a wife. Although sharing this secret with his illegitimate lover/wife - who thus becomes Bluebeard's female helper - Mr Vanstone keeps it from his daughters. Magdalen, "openly excluded, for the first time, from the confidence of her parents" (Collins 2004: 15), will soon learn the twofold nature of secrecy: on the one hand, it is this secret from the past that destroys her childhood happiness, but, on the other hand, she understands that, in order to get what she wants despite the constraints imposed by patriarchy, secrecy is vital. Collins' narrator, referring to Mr Vanstone's example, comments on the danger of building an existence on se- 
crecy: "Nothing in this world is hidden forever. [...T]he inevitable law of revelation is one of the laws of Nature; the lasting preservation of a secret is a miracle which the world has never yet seen." (Collins 2004: 25) The narrator repeatedly alludes to "that past mystery - that forgotten mystery now - of the journey to London" (Collins 2004: 60), where Mr Vanstone, after his first wife's death, was going to finally marry his daughters' mother. It seems as if the secret were forcing its way to the narrative surface. As in earlier Gothic novels, this Bluebeard's secret business is not only mentally, but also spatially hidden: writing a letter concerning the destructive secret of his bigamous relationship, Mr Vanstone "shut himself into the little room, close to the hall-door, which was called his study" (Collins 2004: 76). Here, in his closet, and in the virtual male-homosocial community of letters, he tries to save himself and his family from the destructive power of his secret stigma.

While the secret increasingly begins to overshadow the family's happiness, the houses' inhabitants move further and further into liminal spaces. Even before the actual advent of the catastrophe that will expel her from her home, Magdalen increasingly distances herself from the domestic setting of Combe-Raven, "wander[ing] into the grounds, [...going] into the garden, on the shrubbery side; [... turning] towards the shrubbery" (Collins 2004: 58; 74; 75). The women sit together near the - protective, but implicitly threatened - 'hortus conclusus' of "the flower-garden and shrubbery; this last being protected at its outward extremity by a fence" (Collins 2004: 25). Later, Magdelen and Frank's - the neighbour's son's - ultimately failed courtship also takes place in great parts in the shrubbery (cf. Collins 2004: 51-54), as well as a meeting between Magdalen and her father (cf. Collins 2004: 55).

Even after Mr Vanstone's - and, shortly afterwards, his wife's - death, the destructive secret of the girls' illegitimacy firmly remains, at first, within the homosocial community of men. While Miss Garth, Magdalen, and Norah are still ignorant of their compromising position, Mr Vanstone's male acquaintances and legal advisors, Mr Clare, and Mr Pendril, are in possession of the crucial knowledge: "[T]hey [the women] were in ignorance of the truth." (Collins 2004: 91) To a certain extent, however, Miss Garth takes over the role of 'master' of the house by conducting a business meeting with Mr Pendril in Mr Vanstone's study, "because Mr Vanstone's papers are kept here, and I may find it necessary to refer to some of them" (Collins 2004: 93). Here, Mr Pendril "reveal[s] the painful secret" (Collins 2004: 96). Although law and society act out their power through men, then, it is one of the house's women who, from a discursive point of view, takes charge of information management.

The secret's revelation has a crucial impact on Magdalen, and determines her further development. While Miss Garth tries to hide the secret of the girls' unfortunate position from them, Magdalen, in accordance with her spatially unpredict- 
able nature, has already heard it all "under the open window" (Collins 2004: 114), and, having made Miss Garth aware of her knowledge, "glid[es] away alone, until [she] was lost among the trees" (Collins 2004: 114), increasingly turning into a liminal character, an outsider, in a very tangible sense of the word. This liminality scares both Miss Garth and Norah (cf. Collins 2004: 114/15). In the end, the executors of male-homosocial power drive the women out of the house: "Mr Pendril and Mr Clare advanced into view along the garden path, walking arm in arm through the rain" (Collins 2004: 119), bringing the women news of what will happen to them. As opposed to Miss Garth and Norah, Magdalen meets the men's business on eye level, "suddenly mov[ing] the chair closer to the table. Leaning one arm on it (with the hand fast clenched), she looked across at Mr Pendril." (Collins 2004: 121) Magdalen will not play the obedient role that patriarchy has assigned to her, a fact that Mr Clare immediately recognises: "Fools! [...] Have they no eyes to see that she means to have her own way?" (Collins 2004: 122) Magdalen is now "an unfathomable mystery" (Collins 2004: 126) to Miss Garth and her sister, and Mr Pendril "had his suspicions of her looks; he had his suspicions of her language" (Collins 2004: 127). The men see that this woman's power of bodily and linguistic performance might well make her a threat to the established order. Mr Clare, in fact, accepts that Magdalen's ability to be 'manly' might serve her interests: when, in a weak moment, she "tried to throw her arms around his neck, [...h]e took her by the shoulders and put her back in the chair. [...Y] ou may shake hands with me." (Collins 2004: 131) Mr Clare, while unable to undo the rules of patriarchy that condemn the girls, does not treat Magdalen like a weak woman, but like a strong 'man.'

\section{Liminal Spaces: York}

The novel's second scene is set in York and picks up the theme of Magdalen's increasingly moving into liminal spaces. Skeldergate and Rosemary Lane are described as a place "where the street ends, [...] on the side of it farthest from the river, [...by] the ancient walls of York" (Collins 2004: 148). In many ways, this is a space on the margins: spatially, it is at the outskirts of the old city; temporally, it is associated, through the city wall, with ancient times; socially, because the place is "composed of cheap lodging-houses[;...v]ery little light enters it; very few people live in it" (Collins 2004: 148). Here, Magdalen will join Captain Wragge, her distant relative, a contradictory character, "with eyes of two different colours" (Collins 2004: 149), who knows how to handle secrets to his advantage, and is, just as Magdalen, aware of the power of appearances, wearing a jacket that "kept the dark secret of his master's linen from the eyes of a prying world" (Collins 2004: 
149). "[H]e organises his life and 'work' on the assumption that social identity is performative." (Pykett 2006: 60) Captain Wragge is very perceptive of the spatial options for a woman on the run in a city like York: he concludes that Magdalen will be "out of doors" (Collins 2004: 153), and, indeed, finds her on "The Walk on the Walls, [...t] he quietest place in York: and the place that every stranger goes to see" (Collins 2004: 153). The walls afford Magdalen a certain anonymity among other strangers, and reflect her marginalised social position, "a castaway in a strange city, wrecked on the world!" (Collins 2004: 155).

Wragge's house in York is a good example of the novel's intricate miniature Gothic spaces. Concealed in it lives Mrs Wragge, who is introduced to the reader as an abject figure of pity, no more than a thing: "its knees, [...] its side[..., its upper extremity" (Collins 2004: 162, emphasis mine). She is a woman in the power of the Gothic villain. The narrative, however, immediately ironises this position in having her perform the contradictory move of "looking submissively down at her husband" (Collins 2004: 163). While thus, to an extent, implicitly questioning Wragge's performance as domestic tyrant, Mrs Wragge evokes real empathy and pity in Madgalen and the reader by being "a little slow[...,] a well-trained child" (Collins 2004: 163). She is "a grotesque embodiment of the stereotypical Victorian wife" (Talairach-Vielmas 2005: 66). Captain Wragge performs domestic patriarchal power "as if the whole house belonged to him" (Collins 2004: 163), while, actually, it is a "landlady's" (Collins 2004: 163), that is a woman's house. Wragge has "the air of a prince in his own banqueting-hall[:... ']You see my wife, my house, my bread, my butter and my eggs." (Collins 2004: 168) Instinctively employing a rhetoric of patriarchal ownership, Wragge, at the same time, conveys a mockery of it to the reader, because none of the possessives he uses are actually accurate; and although she ostensibly illustrates "the narrative's patriarchal discourse which deprives women of a name, of a voice, and even of a language" (Talairach-Vielmas 2005: 66), even Mrs Wragge can be understood as representing subversive femininity in that, in her mental state of confusion, she does not adhere to established scripts of a wife's domestic duties (cf. David 1998: 143-145). Even her body itself "is resistant, refuses normalization, collapsing even the boundaries between femininity and masculinity through its gigantic size" (Talairach-Vielmas 2005: 69). What fascinates Magdalen in Wragge, however, is his seemingly being completely unconcerned with social norms: "His entire shamelessness was really superhuman." (Collins 2004: 169) It is this shamelessness that is dangerous to society, because shame keeps people in their place. Faced with a self-avowed swindler, it is difficult, even for Magdalen, to see who Wragge really is. Ironically speaking an obvious untruth, Wragge acknowledges this difficulty on Magdalen's part: "So you see me, exactly as I am.” (Collins 2004: 173) In fact, just like Magdalen, Wragge denies other people the possibility of 'making sense of him,' of 'knowing' him, 
and, hence, making him predictable. He teaches Magdalen to see the world as a stage: "For the present, I withdraw myself from notice. Exit Wragge." (Collins 2004: 173)

Magdalen not only becomes an increasingly better performer, but also an increasingly better liar. She learns to conceal her secrets and private belongings spatially: in a "white silk bag," she carries with her "a lock of Frank's hair" and "a sheet of paper containing [...] extracts [...] from her father's will" (Collins 2004: 177). Here, Magdalen hides both the reason for which she has to learn how to act her way through a hostile world, and the remnant of her wish to accept the codes of patriarchy and heteronormativity in her memory of Frank, a memory that becomes almost sexually tangible: "[The lock] fell from her fingers into her bosom. A lovely tinge of colour rose on her cheeks, and spread downward to her neck, as if it followed the falling hair." (Collins 2004: 177) While Magdalen and Wragge now work together professionally, they begin an epistemological struggle over who can better manage and conceal information. Both know that there are things that the other keeps secret from them: "Captain Wragge's eyes dwelt on the little bag, as the eyes of lovers dwell on their mistress. 'Happy Bag!' he murmured, as she put it back in her bosom." (Collins 2004: 186) Desire for knowledge here becomes aligned with sexual desire: Magdalen's body - or, more precisely, her bosom - is the spatial and metaphorical hiding place of her most private thoughts, and Wragge's desire for her secret thoughts blends into a longing for her body.

Wragge helps Magdalen become a better actress, see life as a performance, and "convert all the world into a stage" (Ford 2004: xii), especially the domestic world: "Take the back drawing-room for the stage, and take me for the audience. [...] You are a born actress. But you must be trained." (Collins 2004: 183; 184) Magdalen gains an increasing "understanding of the theatrical nature of all social roles" (Ford 2004: x). Thanks to her "extraordinary talent as a mimic[..., her] flexible face, [...] manageable voice and [...] dramatic knack" (Collins 2004: 190), she soon becomes a successful stage actress. Her identification with the role of the performer, of being able to impersonate anyone, while, at the same time, 'being' no-one, goes so far that Magdalen completely loses interest in having any sort of public 'identity:' “Give me any name you like.” (Collins 2004: 194) Even Wragge sees something uncannily threatening in "[h]er knack of disguising her own identity in the impersonation of different characters" (Collins 2004: 198): he calls her his "perverse pupil," and comments on her "infernal cleverness" (Collins 2004: 198; 199). Laurence Talairach-Vielmas argues that this dangerous potential of female performativity lies at the heart of Victorian femininity as such:

"Magdalen [...] is both a social void and a representational blank, a signifier lacking a signified. In this way, Magdalen's enterprise in acting on and off 
stage aims to [externalise her figurability], hence defining female identity through make-up and beauty accessories. [...] Magdalen shapes her person as an endlessly reconstructible self, showing how feminine culture and its beauty aids empower women to achieve multiple identity and to engage in a process of self-representation that patriarchal society usually forbids them." (Talairach-Vielmas 2005: 63-64)

Even more paradoxically, patriarchal society both denies and demands this process from women: a person only becomes 'Woman' by performing it, if necessary through the use of make-up and accessories. At the same time, however, 'femininity' is expected to be 'genuine,' and non-strategic. Magdalen's uncanny performances reveal this paradox at the heart of Victorian gender politics, while simultaneously exposing masculinity to be just as paradoxically 'naturally performed;' because although it is true that, here, a woman's "body is a series of fictions read and written in economic terms" (Talairach-Vielmas 2005: 65), a man's body is equally read and written in terms of the management of knowledge.

\section{Degenerate Masculinity: Vauxhall Walk}

The next space the reader encounters, Vauxhall Walk in Lambeth, is dominated by images of decay and degeneracy, strongly associated with the object of Magdalen's pursuit: Noel Vanstone. As in the scene before set in York, the general area of Vauxhall Walk is characterised as a liminal space, a "street labyrinth" with a "maze of houses," where "the hideous London vagabond" (Collins 2004: 210) walks in a district that is dominated by "an awful wilderness of mud and rubbish; the deserted dead body of Vauxhall Gardens mouldering in the open air" (Collins 2004: 211). Associated with nostalgia, death, decay, the outcast, and the dying garden, this space becomes the setting for a domestic power struggle between two women that leaves the only male character weak and superfluous. Performativity, again, plays a major role. In order to be allowed into the house, Magdalen disguises herself as Miss Garth: "[S]he practised the walk [...and] exercised herself [...] in the disguise of voice and manner. [...It was] a triumph in the art of self-disguise." (Collins 2004: 218)

The house itself mirrors the earlier images of decay and degeneracy. Looking into it from the outside before entering, what Magdalen sees is characterised as being "lifeless and changeless as if that room had been a tomb" (Collins 2004: 213); and it will turn out to be the tomb of decaying masculinity. The room is a pastiche that turns the domestic order upside-down: though something like a sitting-room, it contains "[t]wo bedroom chairs," and "a kitchen table" (Collins 2004: 222). The 
table features an object that dominates the whole atmosphere of the room, and foreshadows Mr Vanstone's character:

"On the table stood a glass tank filled with water, and ornamented in the middle by a miniature pyramid of rock-work interlaced with weeds. Snails clung to the sides of the tank; tadpoles and tiny fish swam swiftly in the green water; slippery efts and slimy frogs twined their noiseless way in and out of the weedy rock-work - and, on top of the pyramid, there sat solitary, cold as the stone, brown as the stone, motionless as the stone, a little bright-eyed toad." (Collins 2004: 222/23)

It is worth quoting this paragraph in full because it does so much for the atmosphere of the whole scene. The house, instead of making a first impression of the power, strength, and virility of its master, is associated with images of decay, slime, and 'lower' creatures. The toad reveals much about its male owner: It is small, brown, cold, and motionless - i.e. sterile - as stone. Although its 'bright eyes' seem to suggest that the male-patriarchal gaze remains intact, it is contained by a femininity that clearly sets itself apart from the house's decay: Mrs Lecount's "whole personal appearance was little less than a triumph of physical resistance to the deteriorating influence of time" (Collins 2004: 223).

The encounter between Mrs Lecount and Magdalen demonstrates that the actual power struggle here is between the two women, not between Magdalen and Mr Vanstone. Mrs Lecount both instinctively sees through Magdalen's disguise, and dominates the situation's spatial management. In order to properly see Magdalen's face, she "placed a chair for her exactly opposite the light from the window [...and] sat so close to the wall as to force her visitor either to turn her head a little further round towards the window, or to fail in politeness by not looking at the person whom she addressed" (Collins 2004: 224/25). Both women, ironically, know that they have to play the game in order to succeed; neither of them, at any point, gives up their social performance. Mrs Lecount makes it very clear, though, that power, in this house, lies with her, not Mr Vanstone: "I am the mouthpiece of $\mathrm{Mr}$ Noel Vanstone; the pen he holds, if you will excuse the expression - nothing more." (Collins 2004: 225) With this understatement, Mrs Lecount, in fact, emphasises that, in this house, she is nothing less than the person in charge of the ultimate source of power: language.

By making Mrs Lecount appear first on the scene, she is also given an advantage over Mr Vanstone on a narrative level. Her last allusion to her master's affliction aptly summarises what he lacks: his is "a chronic feebleness - a fatty degeneration - a want of vital power in the organ itself" (Collins 2004: 227). Feeble, degenerate, wanting in vital power (i.e. fertility), Mr Vanstone is anything but 
'manly.' Magdalen's actual encounter with him confirms all these allusions: "His complexion was as delicate as a young girl's, [...with] a weak little mustache. [...] He had a plate of strawberries on his lap, with a napkin under them to preserve the purity of his white dressing gown." (Collins 2004: 228) This man is less a 'man' than a 'girl,' a child, an effeminate, weak being with "a high, thin, fretfully-consequential voice" (Collins 2004: 229). In a culture in which "the body is a measure of masculine and national strength" (Hingston 2012: 120), Vanstone's body is particularly disturbing. He is not even master of his own opinions and actions: he "had been instructed beforehand, what to say and do in his visitor's presence" (Collins 2004: 229). For the whole duration of the scene in Vanstone's room, the two women are in control of space and conversation. Magdalen "dexterously barred the only passage by which Mrs Lecount could have skirted round the large table" (Collins 2004: 229), and "it was Mrs Lcount's habitual practice to decide everything for her master in the first instance" (Collins 2004: 231). While Mr Vanstone busies himself 'delicately' eating strawberries, regularly turning white, or being on the edge of a fit, he is completely oblivious that the two women are battling over politics. This power-triangle clearly departs from traditional constellations: instead of having a woman as the catalyst of a conflict between two men, here it is two women fighting over the - hardly visibly 'male' - body of a man who is no more than an "abject manikin" (Collins 2004: 236). This is doubly ironic, considering that the women not only usurp power, but, to them, it is something of an indignity to have to fight over such a weak specimen of patriarchal masculinity. As this scene, in fact, implies, what makes the patriarchal system most intolerable is that it subjects women to 'inferior' men who can only maintain themselves, because the male-homosocial system bolsters up their privilege - to the disadvantage of women who are much more in control of spatial, epistemological, and even physical power.

\section{Performing in the Theatre of Liminality: Aldborough}

As the story progresses, we move more and more into the liminal outdoors, while the domestic remains the focal point of the narrative, mirroring that Magdalen "is both exiled from and enclosed within patriarchal structures" (David 1998: 137). Magdalen's performative plotting reaches its first climax in the heterotopian space of the shores of Suffolk, where the "extraordinary defencelessness of the land against the encroachments of the sea" enables the dissolution of "traditions which have been literally drowned" (Collins 2004: 266). This is a space of unknown possibility that does not stop at the threshold of domestic space: "Viewed from the low level on which these villas stand, the sea, in certain conditions of the atmosphere, appears to be higher than the land." (Collins 2004: 266) Culture, here, becomes 
marginal and ephemeral in the face of the sea, and the town (i.e. the social) is no more than a "curious little outpost" (Collins 2004: 267).

The place's liminality crucially reflects and influences Magdalen's behaviour. Here, she and Captain Wragge put on their most ambitious social performance: that of a whole family of three made-up identities. The liminal nature of their surroundings also enables the two allies to be unusually honest with each other: in "a little wilderness of shingle and withered grass[..., in] the lost port of Slaughden, with its forlorn wharfs and warehouses of decaying wood" (Collins 2004: 272), that is, again, in a place of simultaneously spatial, temporal, and cultural 'otherness,' "the time had come to be plain with her" (Collins 2004: 272). This is the first and only moment in all of the scenes between the two that they actively declare their wish to be honest, not to be performers for once: "I tell you plainly. [...] She looked round at him for the first time - looked him straight in the face." (Collins 2004: 274; 276) It is also here that Magdalen, once more, displays her tendency to seek out marginal spaces to find the resolution to carry out her plans of domestic politics - in this case, the strength to put on an act that will make Noel Vanstone marry her: "II am going down to the sea[....I]t was as if the night had swallowed her up." (Collins 2004: 280) The further Magdalen pursues her plans that stand in contrast to social normativity, the further she is spatially removed from the centre of society and domesticity. The sea also enables her to let go of the last private bonds that connect her with her old life: "Alone on a strange shore, she had taken the lock of Frank's hair from its once-treasured place, and had cast it away from her to the sea and the night." (Collins 2004: 281) While the liminal outdoors affords Magdalen a certain liberty and ability to face her own thoughts, the privacy of her own room cannot do the same. This space, on the one hand, serves as her 'closet,' and she keeps the keys to its furniture: "[S]he locked [the wardrobe], and put the key in her pocket." (Collins 2004: 291) On the other hand, here, as opposed to outside, she cannot 'unlock' herself and face her fears, which becomes apparent in her inability to look at her own face in the mirror: "For the first time in her life, she shrank from meeting the reflexion of herself." (Collins 2004: 291) Collins' text, then, assumes a female 'I' which, in transgressing the boundaries of normative performativity ('woman,' 'daughter'), cannot be successfully interpellated by patriarchal discourse, and runs the risk of not being able to perform any liveable, recognisable 'identity' at all, and 'get lost' in performance. The liminal, then, while providing the transgressive female with a possible escape from the oppressive spatial semantics of the patriarchal domestic, can only be the temporally limited locus of subversive energies. An ultimate return to a life within patriarchal heteronormativity seems, already at this point, inevitable.

This scene's central space is the town's Parade, which serves as a stage for public social performances. Here, Mrs Lecount can act out the role of protectress 
of her "invalid master" Mr Vanstone for everyone to see: "A very domestic person! a truly superior woman!" (Collins 2004: 292) For Magdalen, the Parade is the place in which she will perform the role of the woman that Noel Vanstone will want to marry. Captain Wragge reminds her: "Don't forget to smile, [...] [and] look happy." (Collins 2004: 294) Again, the struggle over whose performance on this stage will be most successful does not primarily involve either of the two male characters, but Magdalen and Mrs Lecount. This is the public performance of two women struggling over who will gain access to power in a nominally masculine domestic space - namely Noel Vanstone's house, which, according to himself, is "the only safe house in Aldborough. [...] The sea may destroy all other houses - it can't destroy mine. My father took care of that; my father was a remarkable man." (Collins 2004: 298) This claims to be the prototypical patriarchal house: strong, enduring, and handed down in the male line, it represents many traditionally masculine values. It is also, however, flawed: its current master is, as we have seen, feeble and effeminate, and not fit to be its 'patriarch.' He has no sons - or any children - either, so the male line is broken. This is a 'mansion' ready to be taken over by women who have learned the performative language of power politics, a fact that he himself acknowledges: "I can't be left in the house by myself. [...] It all depends on you, Lecount." (Collins 2004: 302)

Captain Wragge is the novel's only male character who is not a fool of conventions. Just like Magdalen, he very well understands his society's performative codes. His character, however, is contradictory. When in a domestic setting with Mrs Wragge and Magdalen, he cannot help act like the 'manly master,' like a Bluebeard. On the other hand, he also knows how to use other people's urge to be 'manly' to his own advantage. He manages to convince Vanstone of Mrs Lecount's acting against him by calling on his 'manliness,' drawing him into his confidence by employing the language of homosocial understanding: "Humour her - make a manly concession to the weaker sex. [...T]ry the suaviter in modo (as we classical men say)." (Collins 2004: 328) Mr Vastone, desperately in need of being treated 'like a man,' is "fully restored to his place in his own estimation" (Collins 2004: 329) by this conversation with Wragge. Similarly, Wragge simulates homosocial respect for the other man's secrets ("I intrude on no man's secrets." [Collins 2004: 333]), only to lure Vanstone into doing the exact opposite: revealing his secrets in the assumed atmosphere of male-to-male confidence. Vanstone, along the same lines, is eager to show Wragge that he is still in control of the management of knowledge in his house: "Of course I can [open the drawer in which Mrs Lecount keeps the account books]. I have got a duplicate key. [...] I never allow the account books to be locked up from my inspection: it is a rule of the house." (Collins 2004: 352) In the end, however, Vanstone's feeble attempts to prove his 'manliness' are 
nothing but weak protestations. Real power lies with those who actually know how to control space and knowledge: the two women, and Captain Wragge.

It is part of the novel's tendency to apologise for its radical gender politics that Magdalen, the further she dares to subvert the patriarchal world surrounding her, increasingly, in moments of weakness, tends towards a passive femininity. She not only "would do what was required of her[..., accept[ing] without a murmur, the monotony of her life at Mrs Wragge's work-table" (Collins 2004: 332, 33), but also opts for a self-imposed imprisonment in the house in Captain Wragge's power. Her passivity is also reflected in her seemingly vanishing from any spatial position at all: she "glided into the obscurity of the room, like a ghost. [...] 'I have no objection to make; I have done with objecting."' (Collins 2004: 342) In her weakest moment, Magdalen, who mostly occupies liminal spaces anyway, becomes a liminal being herself, a ghost-like, passive shadow accepting her destiny. This passivity stands in stark contrast to Magdalen's active occupation, penetration, and subversion of domestic spaces, and can be read - just as the novel's exaggerated 'happy ending' - as Collins' attempt to veil his protagonist's radical spatial gender politics. It also, however, foregrounds the actual pain Magdalen inflicts on herself through her politics of revenge, and, thus, makes her, as a character, very human.

Who will 'win' in this scene depends solely on whose performative power will prove to be most effective, and who will be able to penetrate whose secret spatiality: Mrs Lecount's chance to prove Magdalen's earlier performance as Miss Garth is to "obtain[] access to [her] wardrobe" (Collins 2004: 357), and find the dress of which she has a sample. Similarly, she tries to prevent Magdalen and Wragge from gaining access to - and influence on - Vanstone by "privately remov[ing] the keys from the door in front and the door at the back" (Collins 2004: 371) of Mr Vanstone's house during the night. She finally manages to penetrate Magdalen's 'closet,' and see the dress - proof of Magdalen's secret. Enjoying the power of being a secret bearer too much, however ("The secret of the missing fragment of the alpaca dress was known to no living creature but herself." [Collins 2004: 382]), she decides not to disclose it until her return to England, which she leaves after Wragge has tricked her into going to Switzerland. So, in the end, Mrs Lecount - for now - fails, because she falls for those gestures of power that make her 'more of a man:' keeping secrets.

Images of spatial concealment, in this novel, strongly imply mental processes. Before marrying Vanstone, Magdalen, just as she was earlier able to rid herself of her ties to the past by throwing away the lock of Frank's hair, now enacts a very contradictory gesture. Nervously handling a prayer book that both stands for her past (she took it with her from home) and her approaching future (she opens it at the marriage service), she seems to reject an independent, active decision on her further proceedings in an act of repression, putting the book back into her drawer: 
"[A]fter turning the lock, she took the key away - walked with it in her hand to the open window - and threw it violently from her into the garden. [...] It was invisible; it was lost." (Collins 2004: 395) Caught between her will to actively pursue her ultimate goal, and her tendency to relapse into passivity at the prospect of having to marry a repulsive man, Magdalen tries to refuse herself access to her own secret thoughts, while not revealing them to anyone. This repressed 'closet' of hers, however, in its contradictory nature, drives her to the brink of self-destruction when "[s] he placed [...] laudanum in the cupboard, locked it, and put the key in her pocket" (Collins 2004: 403). Trapped in the 'closet' she has created for herself, two options are left to her: remain passive and die, or regain active strength and a position of power.

Although it is, to a certain extent, true, as Deirdre David observes, that, in having Magdalen use her own charms, "Collins makes us see that disinherited middle-class women, deprived of paternal protection, assume an identity that is both inscribed and concealed by the gender politics of their social class - that of sexual object" (David 1998: 139-140), this is not - as should have become obvious by now - the main reason for Magdalen's subversive potential. Becoming the wife of an older, and rather 'unmanly' man does not make her dangerous, but her not obeying the rules that this institutionalised position would entail does. She will not be the passive, 'feminine' wife, but will use her position, in a very active and 'masculine' way, to get what she wants, a fact that David herself observes in describing Magdalen as "aggressive[ and] robustly in rebellion" (David 1998: 140), as opposed to passive, 'feminine' Laura in The Woman in White. In a similar fashion, I argue against a reading of Magdalen's pursuit of the marriage to Vanstone as a "commitment to masochistic suffering" (Jones 2000: 196). While it is true that the option of masochistic enjoyment of suffering is a common trope of the female Gothic consider Emily's fascination with instruments of torture at Udolpho - Magdalen's use of her body as sexual object in a marriage contract, her "active agen[cy] in her own suffering" (Jones 2000: 201), is not an end in itself, but only one step on her way to regaining position and fortune in an act of self-determined female agency; and this step, far from giving her enjoyment, disgusts, and, indeed, nearly kills her. Her pleasure can only lie in the challenge and promise to overcome disgust, and is, thus, a pleasure of self-mastery, discipline, and stoicism.

\section{Female Domestic Politics: Baliol Cottage}

After Magdalen's plan has succeeded and she has married Noel Vanstone, the reader next encounters them in their new home: Baliol cottage. Far from displaying a scene of domestic happiness though, the narrator immediately confronts us with 
a description of the breakfast-table, which "presented that essentially comfortless appearance which is caused by a meal in a state of transition" (Collins 2004: 439). The narrative ponders over this image for a whole paragraph, conveying a sense of unbalance: the master is being left out, left behind with the leftovers of a meal. Vanstone is not master of this house; instead, he calls Magdalen its "mistress" (Collins 2004: 439). He, who was, from the start, clearly unsuitable to fill the position of virile husband and head of the household, is weaker than before: " $[\mathrm{H}]$ is marriage had altered him for the worse." (Collins 2004: 439/40) He realises that he occupies no position of domestic power: "I'm left here neglected. [...] Am I nobody in the house? [...] Is your mistress to go away on her own affairs, and leave me at home like a child[...]?" (Collins 2004: 440/41) Vanstone is not only de-gendered, but also infantilised. The only pleasures he has are those of infantile cruelty, and an immediate satisfaction of basic needs and wishes.

When Mrs Lecount returns to the scene, it soon becomes apparent again that Vanstone is still only a puppet in the power struggle between her and Magdalen. Although "withered and old" (Collins 2004: 442) herself, Mrs Lecount is still way more powerful than Vanstone, and quickly "resume[s] full possession of him, in her own right" (Collins 2004: 442). Her "merciless steadiness" makes him "dr[a] w back [...], cowering under her eye" (Collins 2004: 445). There is only one point at which Vanstone displays some resistance to his being told what to think and do. When he gets the sense that both women hide knowledge from him, his last outburst is phrased in gendered terms: "[T]hose words lit a spark of the fire of manhood in him at last. [...] 'I won't be threatened and mystified any longer!" (Collins 2004: 446) This 'masculine' protest, however, is not strong enough to match Mrs Lecount's actual spatial power and knowledge. Playing on the image of the male Gothic villain intruding on a woman's private space, Mrs Lecount makes Vanstone do exactly that, not, however, of his own accord: "Take me up into your wife's room, and open her wardrobe in my presence, with your own hands. [...] I don't go near it. I touch nothing in it, myself." (Collins 2004: 447; 448) Lecount forces her 'master' to perform an act of 'masculine' violence (the intrusion of a woman's privacy), to be the Bluebeard she cannot be. Ironically - albeit predictably - this in itself turns out to be an act of violence on Vanstone. The knowledge he is forced to discover (that his wife is not who he thinks she is) is too much for him: "He dropped to his knees, and caught at her dress with the grasp of a drowning man. 'Save me!"' (Collins 2004: 449) This effect is heightened when Lecount breaks open Magdalen's cupboard, and finds the bottle of poison. Vanstone, naturally, jumps to a false conclusion: "Poison locked up by my wife, in the cupboard in her own room, [...] For me?" (Collins 2004: 451) One of the central epistemological acts of the Gothic is, hence, reversed here: instead of gaining power over a woman by denying her privacy and secrecy, the opening of this female 'closet' places the 
threat to the master at the centre of his own domestic space - not, however, in the threat of his own secrets being uncovered (Vanstone does not even have any), but in the very act which, in the world of the Gothic, would normally enable power: that of uncovering secrets.

Mrs Lecount takes the final step of exercising complete control over Vanstone when she talks him into changing his will according to her suggestions: "I will dictate [...] and you will write." (Collins 2004: 457) Vanstone's last resistance is that of epistemological and agential denial: he "said no more. [...] 'I don't remember[....] He clenched his hands, and writhed from side to side of his chair, in an agony of indecision." (Collins 2004: 460) Vanstone has given up all control over his own acts; he is completely in Mrs Lecount's power. This is mirrored spatially in his desire to leave his domestic position and escape his responsibilities: "[H]e looked at the door, he looked at the window, as if he longed to make his escape by one way or the other." (Collins 2004: 463)

Mrs Lecount executes heterosocial power indirectly through her influence on Vanstone, and under the guise of male homosociality. Having talked Vanstone into changing his will so that he will leave all his money to Admiral Bentram, she has him add a secret postscript binding Bartram to handing the money down to his nephew George. The contract, hence, seems to be homosocial (between Vanstone and Bartram), while it is, in fact, indirectly heterosocial (between Mrs Lecount and Bartram via Vanstone). Mrs Lecount thus both shows how aware she is of the importance of secrecy ("[T]he secret way is the sure way, with such a woman as your wife." [Collins 2004: 467]), and how she herself can be defeated by what she does not know, namely that, by giving the money to George, it will finally benefit Norah, George's future wife, and sister of the woman Lecount wants to ruin. Collins skilfully constructs a plot that turns established power structures dangerously upside-down, while, at the same time, always demonstrating the limits to the damage these women can do to patriarchal society.

Collins does, however, set an example in the case of Noel Vanstone: "[T]he abject, miserable little man" (Collins 2004: 476) will not survive his position as the traded object in the power triangle consisting of himself, Mrs Lecount, and Magdalen. Having served first as Magdalen's means to regain a position of power, and then as Mrs Lecount's puppet to take it away again, he no longer has any purpose in this world of female power politics, and dies.

\section{Female-Homosocial Secret Sharing: St. John's Wood}

Before having Magdalen enter the domestic space of her final attempt to find the secret trust that denies her money and position, Collins inserts a short scene of 
confidence between herself and her servant that shows the power of female homosociality. Magdalen, in order to get her maid Louisa to help her, insists on the importance of mutual trust and openness: "I have spoken with the wish to find out more of you and your past life than I have found out yet - not because I am curious, but because I have my secret troubles too." (Collins 2004: 496) Magdalen is aware of the powerful bond the sharing of secrets creates, and Collins here proposes a female alternative to - traditionally much more powerful - male-homosocial secret sharing. Confiding in each other, these two women can help each other get what they want, even - in Magdalen's case - against the powers of patriarchy. The intimacy of the two women's bond is mirrored in Collins' denying the reader explicit knowledge of Louisa's secret: "Magdalen bent over her, and whispered a question in her ear. Louisa whispered back the one sad word of reply." (Collins 2004: 497)

Collins now introduces another ambiguously 'masculine' domestic space. Magdalen's aim is to get into Admiral Bartram's house at St Crux as a servant. When she makes inquiries about the house, it turns out to be - just as all the novel's other houses - not quite the traditional patriarchal household: Magdalen's phrasing of the distribution of power in the house immediately points to the weak standing of masculinity: "The only mistress at St Crux is the housekeeper. But there is a master - Admiral Bartram." (Collins 2004: 500) Not only does the 'master' come second - after the female housekeeper and 'mistress' of the place - but masculinity is generally curiously underrepresented in this house: "[Bartram] will be waited on by women-servants alone. The one man in the house, is an old sailor, who has been all his life with his master." (Collins 2004: 500) This house is inhabited by a man who is not quite his own 'master;' his male companion is the potentially queer figure of the sailor who is associated with the liminal, heterotopian space of the sea; and the rest of the household displays an unusual lack of males. However problematic the standing of masculinity may thus be, the constellation also, again, foreshadows Magdalen's ultimate defeat: while all the servants are women, they will never be anything but servants. Domestic power firmly resides with the exclusively male-homosocial, and potentially homoerotic 'couple' Bartram/Mazey. What remains for Magdalen is, just like for Marian in The Woman in White, to subvert this heterosexist, misogynistic system as an eavesdropper.

Magdalen is aware of the potentially transgressive position of the female servants at St Crux: "I must find my way into St Crux as a stranger - I must be in a position to look about the house, unsuspected - I must be there with plenty of time on my hands. All the circumstances are in my favour, if I am received into the house as a servant." (Collins 2004: 502) Asking Louise to teach her how to be a good servant, Magdalen already performs a socially subversive act; differences of class and position become mere roles to be performed at will: "Shall I tell you what a lady is? A lady is a woman who wears a silk gown, and has a sense of her 
own importance. I shall put the gown on your back, and the sense in your head." (Collins 2004: 503) In a society that depends on people accepting their place in life - be it as a 'woman,' a 'servant,' or a 'lady' - Magdalen becomes an immensely threatening character, because she exposes social norms and conventions to be based on mere performances.

\section{A Queer House: St Crux-in-the-Marsh}

The narrative reaches its climax within the intricate architecture of Admiral Bartram's house at St Crux-in-the-Marsh. Here, in a "servant's costume" (Collins 2004: 511), Magdalen puts on her final performance to penetrate this house's secrets. Although Bartram ostensibly behaves like a proper, powerful patriarch, "a considerate master and an impartial man" (Collins 2004: 513), the one male who is actually in charge of what happens in the house to a certain degree is the sailor Mazey, "the admiral's coxswain" (Collins 2004: 511), that is the person 'steering' the admirals 'boat.' The strong naval analogies at the beginning of the chapter serve to associate the domestic space of St. Crux - its being 'in the Marsh' already adding an element of instability - with the liminal, heterotopian space of the sea. The friendship between Bartram and Mazey is clearly 'odd.' Bartram, having given half his food at dinner to his dogs, announces: "I've got a third dog, who comes in at dessert." (Collins 2004: 514) Mazey's position remains ambiguous, oscillating between servant, friend, and merely tolerated 'dog.' His relationship with his master is hard to grasp, which makes it the more loaded with potential meaning in a house in which the two are the only male inhabitants. The homoerotic connotations of this house's sailor are foregrounded when Magdalen overhears him singing a few lines from the song "Tom Bowling" by Charles Dibdin: "His form was of the manliest beau-u-u-uty." (Collins 2004: 516) Powerfully employed by Herman Melville a few decades later in his story "Billy Budd, Sailor," the male-homosocial admiration of another sailor's beauty is a theme that, in a time of accumulating discourses on 'sexual identities,' has a powerful 'queer' potential.

Magdalen, as a servant, is in a position "to make herself acquainted with the whole inhabited quarter of the house, and to learn the positions of the various rooms" (Collins 2004: 515). Ironically, it is Mazey who leads Magdalen through the passages of the house, which proves to be even stranger than its unusual inhabitants and its association with the liminal have suggested. The house is divided: the uninhabited northern part, which contains "the ancient Banqueting-Hall of St Crux," is called "the Arctic Passage" (Collins 2004: 518). It is "foul with dirt and cobwebs; the naked walls [...] were stained with damp; [...it was a] wilderness" (Collins 2004: 518). Collins neatly combines various layers of liminality within 
this one space: geographical (it is associated with polar regions), temporal (it is ancient, and in decay), and immediately spatial (this is a remote and uninhabited part of the house). The narrative pushes this heterotopian quality of the house in its entirety to the extreme: Magdalen finds out that Bartram "likes to shift his quarters, sometimes to one side of the house, sometimes to the other" (Collins 2004: 518), the southern part, "which is all tumbling about our ears" (Collins 2004: 519); and the gardens in between the parts are "neglected [...and] overgrown with brambles and weeds" (Collins 2004: 519). Although this place is marked as fading, ephemeral, strange, in-between, and hard to grasp, and could thus be associated with a weak standing of masculinity, its liminal nature is more problematic. Despite its dilapidation, St Crux-in-the-Marsh turns out to be a fully functioning homosocial/ heterosexist/misogynistic domestic heterotopia. While Bartram, as we will see below, does bear the paranoid markers of paranoid masculinity, he is protected by Mazey's policing presence, and the two men's 'queer' power makes it impossible for Magdalen to succeed. Within the novel's gender politics, this power is, however, monstrous, in that it not only retains the misogyny of heternonormative patriarchy, but also eliminates both heterosocial and heterosexual desire.

The excessively homosocial nature of the relationship between Mazey and the admiral becomes even more odd when the reader learns that Mazey, in his "doglike fidelity to his master" (Collins 2004: 521), sleeps in front of Batram's room at night in a passage that is out of bounds to Magdalen. When she asks him about it, Mazey's answers are strangely evasive, only reminding Magdalen that it is not a woman's business to spy on the dealings of men: "Don't be curious. Look in your Old Testament when you go downstairs, and see what happened in the Garden of Eden through curiosity. Be a good girl - and don't imitate your mother Eve." (Collins 2004: 522) The biblical reference, in this context, reminds the reader that patriarchy's reliance on the power of secrecy is an ancient phenomenon. The impression of Mazey's threat is twofold: on the one hand, it alludes to the paranoid structures of Bartram's homosocial secret (the hidden document); at the same time, however, the threat becomes real when Magdalen does 'eat the apple,' only again to be denied epistemological satisfaction and power.

St Crux is full of locks, an accumulation of 'closets' of all shapes and sizes. In the library, "[t]here was a table [...] with drawers that locked; there was a magnificent Italian cabinet with doors that locked; there were five cupboards under the book-cases, every one of which locked" (Collins 2004: 525). Bartram regularly displays a "fidgety anxiety about his keys and his cupboards[;...] some private responsibility [...] tormented him with a sense of oppression" (Collins 2004: 525). The secret Bartram has been left by Noel Vanstone, in this final scene, comes to stand for the dynamics of masculine secrecy as such. It makes Bartram paranoid and obsessed with the practical and symbolic power of keeping his keys safe: 
"[S]ometimes, he took them up to the bedroom with him in a little basket." (Collins 2004: 526)

Unsurprisingly, it is, once again, a liminal space outside the house in which Magdalen literally finds the first keys to the discovery of the secret trust: in the garden. Its liminality is emphasised by its containing "the ruins of [an] old monastery" (Collins 2004: 538), a powerful architectural metaphor that carries multi-layered meanings: the temporal heterotopia of the decaying past in the present; the death of the powerful patriarchal institution of the church; and an allusion to more traditional Gothic architectures on the basis of which this novel's spatial gender politics are constructed. Here, Magdalen finds an array of old keys lying on the ground: "What if she collected all she could find, and tried them, one after another, in the locks of the cabinets and cupboards now closed against her?" (Collins 2004: 539)

It is, ironically, the admiral himself who leads Magdalen to the discovery of the locus of the search, the house's most secret space of all. She gets a first hint from watching him enter the house's east wing, that uninhabited part at the other extreme of the liminal space of the 'Arctic Passage:' "[S]he had accidently surprised Admiral Bartram on a visit to the east rooms, which, for some urgent reason of his own, he wished to keep a secret." (Collins 2004: 544) In a way very much reminiscent of Falkland in Caleb Williams, Bartram's masculinity is such that its paranoia creates an urge to disclose the secret, get rid of the burden that simultaneously empowers these men's self-concept, and leads them into crisis. What follows confirms this impression: when Magdalen finally attempts a nightly excursion into the Gothic Banqueting-Hall - in the middle of which a "tripod rose erect on its gaunt black legs, like a monster called to life by the moon - a monster rising through the light, and melting invisibly into the upper shadows of the Hall" (Collins 2004: 546) - and discovers "an old bureau of carved oak" (Collins 2004: 547), she is surprised by the sleepwalking figure of Admiral Bartram, who seems to be driven mad by the secret he has been asked to keep: "My good fellow, Noel, take it back again! It worries me day and night." (Collins 2004: 548) Reduced to a death-like state (“[t] he awful death-in-life of his face" [Collins 2004: 549]), Bartram himself, through his actions and language, confirms to Magdalen that the bureau is the 'closet' she has been seeking to penetrate. What is more, he even leads her back into his own room, unconsciously exposing himself and his keys to Magdalen's access: "She took all the keys from the table." (Collins 2004: 550) Collins confronts his readers with a masculinity that, although protected by a 'queer,' homosocial system of surveillance, remains paranoid.

Even though Bartram's unconscious drive to rid himself of the secret exposes it to female access ("At last, she drew out the inner drawer! At last, she had the letter in her hand!" [Collins 2004: 551]), homosocial control of its content remains intact. One reason for this are certainly Collins' expectations concerning his readership. 
He wrote for a popular audience, at a time at which it was expected that the order of things remain ultimately unquestioned. His subversive ideas "are disciplined by the contingent demands of his career, by the male-dominated directives of his culture" (David 1998: 146). He also, however, within the logic of his narrative, demonstrates the potential monstrosity of a purely homosocial, misogynistic power structure. When Mazey catches Magdalen just as she has opened the 'closet,' and got at the secret, he aptly puts her crime against patriarchy into words: "His honour the admiral's keys stolen; his honour the admiral's desk ransacked; and his honour the admiral's private letters broke open." (Collins 2004: 553) Both what the reader knows about Mazey's position in the house, and his current state ("[His] eyes were bloodshot; his hand was heavy; his list slippers were twisted crookedly on his feet; and his body was swayed to and fro on his widely-parted legs." [Collins 2004: 552]), however, give his performance of masculine authority a subtle, but clearly comic touch; and although he claims to know that his "duty is to turn the key on" (Collins 2004: 557) Magdalen, he does not make use of this power, and lets her go. Collins, then, makes it obvious that, although Bartram's paranoid predisposition has helped Magdalen get access to the information she is after, homosocial power cannot be broken. The secret's discovery has been ultimately prevented, but Collins clearly criticises this form of patriarchal, heterosexist, misogynistic power, structured around secrecy. Having the paranoid Bluebeard die ("[O]n the day when the girl's treacherous conduct was discovered, the admiral was seized with the first symptoms of a severe inflammatory cold." [Collins 2004: 566]), he foregrounds the enormous energy patriarchy has to expend in order to keep up its sexist privilege.

Although Collins ostensibly re-establishes the order of things in making Magdalen's subversive project fail, and having her personal story end with a comically exaggerated, heteronormative, romantic plot - she is saved from illness and poverty by another sailor: Kirke, "whom she marries in a symbolic reconciliation with the father figure who left her legitimate but disinherited at the beginning of the novel" (David 1998: 139) - an alert reader will easily conceive that the novel's subversive power is only seemingly reversed. The story of Magdalen's failure and ultimate return to a 'normal' life is told in so brief a space, compared to what precedes it, that it is obvious that Collins did not intend to put an emphasis on the reconciliatory tone of his novel's ending. Many critics have, in fact, negatively remarked on the suddenness of this turn at the end of the novel (cf. Thoms 1992: 87). Others realised that this "conversion runs counter to the true energies of the text, and represents and unnatural taming" (Thoms 1992: 90). It is no coincidence that it is the potentially 'queer' figure of the sailor who stands in as the powerfully male 'saviour,' questioning a re-domestication of the subversive female within the patriarchal system of control. Heternormative bliss is just as foreclosed as female-homosocial independence. Although it is Norah who opens Bartram's 'clos- 
et,' and removes the secret trust, she only does so acting for her husband; and while money, name, position, and power return to the female characters, they only do so through male-homosocial inheritance. Collins exposes the weakness of patriarchal, paranoid masculinity, and only has the 'queer fishes' (Wragge, Mazey, and Kirke) survive, but, at the same time, foregrounds a concern with the misogynistic potential of an excessively homosocial society, in which women remain dependent on the economic, epistemological, and political power of men.

\section{A Female Bluebeard: Mary Elizabeth Braddon's Lady Audley's Secret}

Over the last decade, the importance of Mary Elizabeth Braddon's fiction for an understanding of Victorian culture has been increasingly recognised in literary scholarship. Her writing was extremely popular at the time, and "crossed boundaries in readership, style, and the politics of socioeconomic identity" (Tromp et al. 2000: xvi). In Lady Audley's Secret, her most famous novel, and a "dynamic portrayal of mid-Victorian masculinities" (Heinrichs 2007: 103), epistemological power relations are turned upside-down. While the patriarchal home is the narrative's central space, its actual core is occupied by a female protagonist's intricately shaped secret rooms, rooms that help her protect a secret from her past that - in a complete gender-inversion of the traditional Gothic plot of the Bluebeard type threatens her very existence as the person in charge of the management of knowledge.

"Women, indeed, rule the novel. It is their actions that determine the course of things." (Klein 2008: 170) Fooling a husband who is reduced to an existence in his bedroom, Lucy Audley is chased by Robert, a man who, in the cultural context of increasingly rigid discourses on sexualities, struggles not only with protecting the system of male-homosocial patriarchy from Lucy's subverting influence, but also with his own 'sexual identity.' Set in a time during which ideas of gender, and especially of masculinity, were being constantly redefined, and "a fading honour-based model of masculinity" (Heinrichs 2007: 103) was increasingly questioned, Braddon not only "speak[s] against [...] existing models of passive femininity" (Woolston 2008: 165), but also participates in a discourse that re-negotiates the spatial and social position and 'identity' of men, achieving "a subversive deconstruction of gender stereotypes" (Klein 2008: 162).

While the domestic, as in many sensation novels, proves not to be the safe haven of patriarchal power any longer, "call[ing] into question notions of gendered identity and the domestic order" (Tromp et al. 2000: xvii), the novel's protagonists find themselves increasingly pushed into marginal, heterotopian spaces that lack definite meaning, security, and social structure. Gardens, graveyards, and the sea 
become the sites in which masculinity struggles to redefine itself against both a dangerously subversive femininity (Lucy Audley), and the unspoken knowledge of sexual deviance (Robert's 'queer' desire for George). In this “subversive portrait of alienated patriarchy" (Gilbert 1997: 94), men - and a woman! - struggle and fail to perform a stable masculine identity: "Braddon suggests that masculinity is as much a spectacle as femininity, and, thus, questions patriarchal social authority." (Heinrichs 2007: 113) The patriarchal domestic is marginalised, and those characters who are associated with it - like Sir Michael - are ultimately expelled from it. In contrast, those male characters - like Robert and George - who are emphatically associated with the liminal, and increasingly move within heterotopian spaces (the seaside, the graveyard) fail to perform a functional form of masculinity that conforms with patriarchal ideals. In the end, however, they are also enabled to move beyond notions of paranoid masculinity, and find peace in what Braddon constructs as a 'queer' fairy-tale ending, a life together in a country cottage, out of reach of the normative conventions of their society. A stable, heteronormative masculine identity is only temporarily achievable through the spatial marginalisation of the subversive female in an asylum, and the 'closeting' of her existence and the threat she poses. Both Braddon's male characters, and her protagonist Lady Audley strive - or instantly fail - to be Bluebeards, to have and control their own secrets, and to manage the spatial movements of themselves and those around them. Strikingly, Lady Audley as a female Bluebeard is the only character who - temporarily - successfully performs a secretive identity that bears the markers of patriarchal, secretive, paranoid masculinity, which, in the end, is exposed as an unliveable myth.

\section{Female Secret Space: Audley Court}

The narrative begins with a description of Audley Court, the house that Lucy Audley is going to be mistress of. It is characterised as a mock-Gothic architecture, a strange place, in which time itself does not adhere to its own rules: the clock tower's "stupid, bewildering clock" is "always in extremes" (Braddon 1998: 7). The house, which used to be a convent, is "very irregular and rambling" (Braddon 1998: 7), and the main entrance is so hidden that it seems that it "wished to keep itself a secret" (Braddon 1998: 8). Although described as a "glorious old place" (Braddon 1998: 8), its best days are past, and the house's exterior seems drained of life, symbolised by "the stagnant well" (Braddon 1998: 8). The building is a pastiche of styles, and the narrator warns us that this is "a house in which you incontinently lost yourself" (Braddon 1998: 8). The narrator, while employing a lot of the language that would be used to describe a castle in the Gothic literary 
tradition, at the same time makes fun of these genre-specific allusions: "Of course, in such a house, there were secret chambers" (Braddon 1998: 9), and the lime-tree walk "seemed a chosen place for secret meetings or for stolen interviews" (Braddon 1998: 9). By deliberately employing a rhetoric that simultaneously evokes and creates an ironic distance to the Gothic horrors that Braddon's readership would associate with a description such as this, her narrator paves the ground for shattering false expectations of domestic harmony at Audley Court. This house does have secret rooms; they do not contain the secret of a male Gothic villain, but will turn out to be the house's mistress'; and the lime-walk, as, indeed, all of the surrounding outdoors, will be the space into which the ensuing power struggle is taken. The house itself, as representing masculine power, loses meaning as a site of stability and masculine (sexual and economic) virility: "The novel continually effaces all signs of productivity on the Audley estate, [...and] constant images of stagnancy" (Haynie 2000: 70-71) abound.

Lucy is introduced to the reader as a woman with a mysterious past: "No one knew anything of her," and "nobody exactly knew her age" (Braddon 1998: 11; 13). As the reader finds out at the end of the novel, what Lucy hides is the fact that she is already married when she becomes mistress of Audley Court. The house's interior reflects her secret in a very similar fashion to the labyrinthine architecture of the Gothic castles hiding their male owner's secrets. This female Bluebeard's 'closet' is so elaborate that it immediately stands out in the narrative as the most curious and most interesting part of the whole house. Through the eyes of Phoebe, Lucy's maid, the reader learns that one enters her mistress' apartments through "an octagonal chamber" (Braddon 1998: 33), from which a door, veiled by "a heavy green cloth curtain" leads into "a fairy-like budoir" (Braddon 1998: 33), and from there into a dressing room. The space has an unreal atmosphere; both the green curtain and the French and Dutch landscape paintings in the octagonal chamber suggest the foreign, the outdoors, a feminine 'other' space of fairy-tale-like mystery.

At the very beginning of the novel, Lucy's 'closet' is penetrated successfully for the first time: Phoebe and Luke, her cousin and husband-to-be, on their secret visit to Lucy's chambers, during which the young man feels "gawky embarrassment" (Braddon 1998: 33) at being in this feminine space, find "the massive walnut-wood and brass inlaid casket" (Braddon 1998: 33) in which Lucy keeps her jewellery, and the keys to which "she always keeps [...] herself" (Braddon 1998: 33). Finding the keys in the room, however, Phoebe opens the casket, and Luke discovers "a brass knob in the framework of the box" that opens "a secret drawer" (Braddon 1998: 34). Here, in the most secret place of Lucy's strange apartments, they discover the hidden clues to her past: "a baby's little worsted shoe rolled up in a piece of paper, and a tiny lock of pale and silky yellow hair" (Braddon 1998: 34). In hindsight, the reader knows that these belong to Lucy's child from her first 
marriage with George. Spatially, Lucy's closet has been opened; neither the two characters, nor the reader can, however, read the signs at this point in the narrative. By opening Lucy's spatial closet way before the mental secret can be understood, Braddon provides her readers with strong spatial and physical signifiers that make them look for the missing signified for the rest of the story.

Lucy's rooms also serve to show female-homosocial intimacy that is always on the brink of going too far. When Lucy and Phoebe are alone in Lucy's dressing room, she flirtatiously "throw[s] back her curls at the maid" (Braddon 1998: 60), and tells Phoebe: "[Y]ou are like me" (Braddon 1998: 61), and sends her on a secret errand to London to help Lady Audley plot against the latter's male opponent Robert Audley. This kind of female secret sharing between mistress and servant appears shocking to Alicia (cf. Braddon 1998: 60), the daughter by a previous marriage of the novel's nominal patriarch, because it breaks down established barriers of class - as, of course, does Lucy's marriage to her new husband in the first place - but it also has the potential to scandalise its readers due to its potentially erotic undertones: before retiring for the night, Lady Audley says, "Kiss me, Phoebe." (Braddon 1998: 61) Setting the most intimate encounters between Lady Audley and Phoebe in the former's private apartments, Braddon creates a space that strongly plays on the potentially scandalous nature of the male closet's homoerotic connotations, but reverses its gender: she is not interested at all in what the master of the house might be doing 'in private,' but Lucy's rooms and its secrets are intriguing. Hence, Lucy's 'male paranoia' that her secret - that she is married to two men - might be found out gets associated with the paranoid structures of the male-'homosexual' secret. So far, however, she is in control over who gains access, and who does not: Before leaving for London, "she paused deliberately at the door of [the octagon ante-chamber], double locked it, and dropped the key into her pocket. This door, once locked, cut off all access to my Lady's apartments." (Braddon 1998: 62)

Remarkably, every time someone plans to go to Lucy's rooms, they do so in a movement from the liminal outdoors surrounding the house. Before taking Luke to see the room, Phoebe meets him in the house's uncanny gardens, because "it's better talking out here than in the house where there's always somebody listening" (Braddon 1998: 30). Similarly, and, once again referring to "[t]hat stupid clock, which knew no middle way" (Braddon 1998: 68), Robert and George meet Alicia, Sir Michael's daughter and Lucy's rival, in the lime-walk, and George observes that this place "ought to be an avenue in a churchyard" (Braddon 1998: 68). The garden, far from being "a safe enclosure, a cultivation of life and fertility, movement from season to season where life is ordered" (Hedgecock 2008: 136), is repeatedly associated with the liminal, the old, the dead, and the strange, always using the same imagery: the weird clock, the ruins, and the old well. Deliberately 
over-emphasising the heterotopian qualities of the house's grounds, Braddon creates another 'different space' outside the domestic that is closely linked to Lucy's rooms inside. Both, it seems, are spaces of possibility and action, while the patriarchal domestic - the library, Sir Michael's rooms - get pushed to the narrative's margins. Again mocking the fictional architecture of the traditional Gothic, Alicia leads the men to Lucy's apartment - repeating the denial of the house's 'normal' properties by entering not through a door but "an open French window" (Braddon 1998: 68) - by way of a secret passage that Lucy does not know about. George, just like Luke, feels "out of place [...] among all these womanly luxuries" (Braddon 1998: 71). In a parallel movement of penetration to that of Phoebe and Luke earlier, the three characters discover what they have been looking for: Lucy's portrait. What is striking is the reversed epistemological effect: while the artefacts that Lucy had actually hidden did not mean anything to the people finding them, this portrait, as insignificant a signifier as it may seem, is read by George as the actual spatial representation of Lucy's secret. Its peculiar positional and metaphorical value is emphasised by a spatial doubling: displayed in the strange octagonal chamber, the portrait itself was done with Lucy "standing in this very room" (Braddon 1998: 71). The picture itself also seems to speak of Lucy's secret character: the painter has given "a strange, sinister light to the deep blue eyes," and a "hard and almost wicked look" (Braddon 1998: 72) to her mouth. This portrait exposes Lucy's hidden self in a twofold movement: George, of course, recognises his wife in it; the reader, not knowing as much yet, is further intrigued by the signs the three characters find in Lucy's 'closet.'

George, however, cannot or will not confront Lucy with what he knows within the patriarchal space of the domestic indoors. Their only open confrontation, of which the reader learns conspicuously little, takes place in the liminal outdoors of "the shadowy lime-walk" (Braddon 1998: 80). The mysterious nature of this part of the garden now extends to the narrative in denying the reader an account of what happens there. A spatial and temporal gap in the narrative, however, draws attention to this scene's significance: "It was a full hour and a half after this when Lady Audley returned to the house, not coming from the lime-walk, but from exactly the opposite direction." (Braddon 1998: 80) In the end, we know, of course, that George confronts Lucy in the garden, and she pushes him down the old well, intending to kill him. Whether or not one knows this yet, however, the impression is strikingly similar: while we learn in the end that Lucy actually attempts to spatially enact on George's body what she has already done mentally (namely making him part of her house's secret spatiality by having him disappear in the old and broken well that signifies her secret past), even without this knowledge, it seems that the strange house and its grounds, over both of which Lucy has power, have swallowed up the male who know too much. The very physical level to which 
Lucy's attempt to erase her past has come, however, makes her vulnerable: when Sir Michael and George discover "a bruise upon her delicate skin" (Braddon 1998: 90) her body becomes the object of a scrutinising male gaze: "Sir Michael came across the room to look into the matter of the bruise upon his wife's pretty wrist [... and] took [it] in his strong hand. [...] It was not one bruise, but four slender, purple marks, such as might have been made by the four fingers of a powerful hand that had grasped the delicate wrist a shade too roughly." (Braddon 1998: 90-91)

While Lucy is generally the one who knows how to manage the house's secrets, and the knowledge concealed therein, in this instance, when her body betrays her, she is reduced to her female body and the physical mark on her skin that Robert (correctly) reads as a visible sign of Lucy's dishonesty: "My lady tells little childish white lies." (Braddon 1998: 91)

As opposed to the house, the lime-walk enables the characters to drop their usual pretences and make underlying conflicts explicit. The space also triggers a fundamental change in Robert's behaviour, in that, in the rare confrontations with Lucy, he enacts a strong and active masculinity that he is unable to perform on the 'stage' of the domestic: "It is in these encounters that the previously weak and indolent Robert most displays male supremacy [...], takes on an active role and asserts himself as a man.” (Klein 2008: 164; 165) In a rare moment of frankness, he confronts Lucy with his suspicions that she is responsible for George's disappearance. During the whole scene, the aggressive conversation is interspersed with the narrator's comments on the liminal nature of the place: "The lime-walk seemed like some cloister in this uncertain light[...,] a gloomy place. [...] A winding pathway, neglected and half choked with weeds, led towards [the] well." (Braddon 1998: 263; 268; 270) Braddon constructs a space that, due to its 'otherness,' both enables an unusual openness in the characters, and reflects still unspoken truths. The well that Lucy and Robert are moving towards is where George disappeared, and Lucy's crime is foreshadowed by a focus on the well's "iron spindle [that] had been dragged from its socket, and lay a few paces from the well, rusty, discoloured, and forgotten" (Braddon 1998: 270). The lime-walk's spatiality has an epistemological dimension of its own; it subtly adds additional layers of information, and serves as an enabling background for the characters' behaviour.

Another movement from the outdoors into Lucy's rooms at a later point in the narrative again emphasises both her homosocial/homoerotic relationship with Phoebe, and the power Lucy has over the space she inhabits. While the grounds, and especially the well, which "must have been half choked up with the leaves that drifted about it, and whirled in eddying circles into its black, broken mouth" (Braddon 1998: 109), increasingly reflect the precariousness of Lucy's secrets, she meets Phoebe in the garden, and starts to reflect on the nature of her own situation, remembering a fairy-tale-like "French story [...] of a woman who committed 
some crime. [...] Do you remember how she kept the secret of what she had done for nearly half a century, spending her old age in her family château [...until] her secret was revealed?" (Braddon 1998: 109) Of course, Lucy here, in the garden with Phoebe, alludes to her own life, and both the surroundings, and the fairy-tale character of her story from France make the reader remember Count Bluebeard: Braddon is aware of Lucy's position as a woman employing a politics of domestic secrecy that has, for centuries, been a means of power for men. Adopting these strategies of secrecy, however, Lucy also experiences the 'male paranoia' of so many Gothic villains before her. Accordingly, she reverses the gender of a rhetoric traditionally excluding women for the sake of close male-homosocial bonds through her intimate companionship with Phoebe. The homoerotic undertones of this relationship add to the association of Lucy's 'male paranoia' with the paranoid structures of the male-homosexual secret: "While Lady Audley's commission of bigamy is an irrefutable sexual secret, so too may be her hidden physical attachment to Phoebe." (Woolston 2008: 163)

Lucy's paranoia makes her blackmailable. Phoebe, in fact, who wants to leave her position to marry her cousin Luke, makes the reader - and Lucy - aware of Lucy's precarious position by again alluding to the Bluebeard myth, and (naively) turning it on Lucy: she tells her mistress that she thinks "that it is just such men as he [Luke] who have decoyed their sweethearts into lonely places, and murdered them for being false to their word" (Braddon 1998: 111). This is exactly what Lucy, the female Bluebeard, has done. What is more, Luke blackmails Lucy into giving him money by hinting at something he knows about her through Phoebe. The actual content of the supposed secret that is being communicated is never mentioned, which leads to a misunderstanding: Luke threatens Lucy on the basis of what he has seen on his visit to her rooms; Lucy, however, assumes that he and Phoebe must know more. "[R]eaders are left in the dark as to what was revealed." (King 2008: 60) The power that Luke holds over Lucy here is simply one of language: the fact that he hints, "with quiet insolence, that had a hidden meaning" (Braddon 1998: 113), at knowing something, is enough to make Lucy afraid. At this point, however, Lucy's mere physical presence still makes her more powerful than Luke in spatial terms: she deliberately stages her meeting with him to make an impression, with "her rippling hair falling about her in a golden haze. Everywhere around her were the evidences of wealth and splendour." (Braddon 1998: 112) While she has to give in to Luke's rhetoric, her body and surroundings still enable her to make "his determined gaze s[i]nk under hers" (Braddon 1998: 113).

It is crucial to emphasise the reversal of gender roles that Lucy performs on the level of epistemological power politics, because this is what makes her character so provocative. While it is true that what must have shocked Victorian readers about the novel was Lucy's "unnatural embodiment of femininity," that she " llooked the 
part' of Victorian woman and wife but refused to 'be' it inside" (Voskuil 2001: 614; $613)$, that she exposed the gaps between a contemporary, almost essentialist notion of 'ideal femininity' as “idealized human subjectivity" (Voskuil 2001: 619), and its actual, potentially merely performative nature, Braddon's subversive move goes further. In making her heroine, who has an uncannily "elastic ability to define and redefine herself" (Nemesvari 2000: 111), perform a role that places her (temporarily) at the (spatial) centre of power over knowledge, a position traditionally associated with masculinity, but at the same time having her experience the equivalent 'male paranoia,' Braddon does not primarily denounce deviant - or excessively idealised (cf. Tatum 2005: 135-155) - performances of femininity, but exposes the paranoid mechanisms of a masculinity that both bases its power on pathological structures of knowledge, and cannot be performed successfully by either a woman or a man, as will become obvious later in a more detailed discussion of the novel's male characters. Braddon, hence, does not simply construct Lucy as an "economic, sexual, and criminal 'Other" (Woolston 2008: 157), who, as "femme fatal, [...] subverts the law and acts as a hidden predator" (Hedgecock 2008: 112). Although she is "defined by her idealized asexual beauty and her childishness" (Langland 2000: 11), this is true only (and this is crucial) insofar as she consciously enacts this childlike, female 'Other.' Braddon, in fact, places her heroine at the very (spatial) centre of the 'Self' that patriarchal society has constructed as the locus of masculinity, while, at the same time, delegitimising the basis of any gendered power imbalance based on performances that are doomed to constantly fail.

In the end, when Lucy realises she has been found out, losing control over the knowledge of her secrets, she also loses control over the house's spatiality. Leaving the house at night in a last desperate attempt to silence Robert, she walks through its rooms, which seem no longer to obey her will. She passes through another octagonal chamber which, however, now is associated with the library and male power (cf. Braddon 1998: 310); she cannot leave the house through the main doors because "[t]he secrets of the bolts, and bars, and chains, and bells which secured these doors [...] were known only to the servants" (Braddon 1998: 310); and the breakfast-room she passes through is "more occupied by Alicia than any one else" (Braddon 1998: 311), her rival, and her persecutors' female accomplice. It seems as though the house itself were expelling Lucy: leaving the grounds, "it seemed as if she disappeared into some black gulf. [...] The stupid clock struck twelve, and the solid masonry seemed to vibrate under its heavy strokes, as Lady Audley emerged upon the other side." (Braddon 1998: 312)

Later, having set fire to a nearby public house in an attempt to kill Robert, Lucy tries, once again, to fortify herself mentally and spatially against the danger she is facing, turning her apartment into an actual and mental fortress: "She had locked the door to guard against the chance of any one coming in suddenly and observing 
her before she was aware - before she had sufficient warning to enable her to face their scrutiny." (Braddon 1998: 329) Simultaneously, however, shortly before she learns that Robert has survived, her panic makes the whole house seem to drift off further and further into the uncontrollably liminal, a process which reflects Lucy's mental loss of control: "The flat meadows were filled with a grey vapour, and a stranger might have fancied Audley Court a castle on the margin of a sea." (Braddon 1998: 335-36)

When Lucy finally confesses her crimes, she does this in an active spatial movement into the patriarchal realm. When Robert asks her if there is a room in which they can talk alone, "[m]y lady only bowed her head in answer. She pushed open the door of the library" (Braddon 1998: 338). This spatial gesture of a voluntary acceptance of a male verdict is broken, however, in that we learn in the same paragraph that "Sir Michael had gone to his dressing-room to prepare for dinner after a day of lazy enjoyment; perfectly legitimate for an invalid." (Braddon 1998: 338) Although Lucy's power is broken, it is not the house's nominal master who fills the gap; he has been a weak and powerless man from the beginning, a man who mostly occupies the house's more private parts. Prioritising heterosexual sentimentality over his duty to the patriarchal community of men, Sir Michael cannot sustain a position of power in a world which Braddon constructs not only as misogynistic and homophobic, but also excessively homosocial.

In the course of the narrative up to this point, both male protagonists are exposed as representing problematic masculinities, and both are confronted with the fact that the only character who has been successfully managing knowledge has been the deviant woman. The only solution to this, considering that a contemporary readership would expect deviance to be 'normalised,' is for Braddon to make her characters perform linguistic acts that are uncomfortably at odds with their previous actions. Lucy, the deviant woman, must be declared 'different.' Robert, hence, de-genders her ("Henceforth you must seem to me no longer a woman." [Braddon 1998: 340]), and Lucy declares herself mad ("You have conquered - a MADWOMAN!" [Braddon 1998: 340]). While Sir Michael remains the passive reminder of the patriarch's impotence ("[T]hat imperious hand dropped feeble and impotent at his side. [...] He sat silent and immovable." [Braddon 1998: 341; 344]), leaving action to Robert ("I leave all in your hands." [Braddon 1998: 361]), the young man feels extremely uncomfortable with this "awful responsibility" (Braddon 1998: 361). Neither man is inclined to actively occupy the spatial power vacuum that Lucy leaves in the house, a fact also reflected in Robert's being accommodated in his "old room" (Braddon 1998: 364), rather than, in Sir Michael's absence, in any spatial position of higher authority. This precarious situation can now only be resolved by introducing a discursive voice that saves the men from making decisions themselves, modern society's deus ex machina: the doctor. His declaring 
Lucy insane and shutting her away in a madhouse releases Robert and Sir Michael from their responsibility, but this solution remains unsatisfying: Braddon, while accepting the fate of her deviant heroine, leaves her male characters exposed and weak, an effect she mainly accomplishes through her construction of space.

\section{Suspended Masculinity: Talboys Mansion}

Apart from Audley Court, the novel's only other aristocratic mansion is George's father Harcourt Talboys' house. It both stands in contrast to the former, in that it is the novel's only domestic space in which power really lies in the master's hands, and complements it, in that the masculinity it stands for is stagnating. The house itself provides the backdrop for an unstable and unrealisable heteronormative fantasy that Robert's homoerotic desire for George, which I will discuss in detail below, gets mapped onto. To an extent unparalleled by any of the novel's other architectures, Mr Talboys' house explicitly represents its owner, and his excessive desire for a 'correct,' normative existence: "Mr. Harcourt Talboys lived in a prim, square, red-brick mansion. [...] The prim, square, red-brick mansion stood in the centre of prim, square grounds, scarcely large enough to be called a park, too large to be called anything else - so neither the house nor the grounds had any name, and the estate was simply designated Squire Talboys." (Braddon 1998: 183)

In its pursuit of correctness, the house achieves exactly the opposite of what its design aims at: being excessively ordinary and mediocre, it lacks the basic quality of being given a name. Striving for normality, then, the house loses identity. This impression can easily be extended to Mr Talboys himself, who "was like his own square-built, northern-fronted, shelterless house. There were no shady nooks in his character into which one could creep for shelter from his hard daylight. He was all daylight." (Braddon 1998: 183) This is a crucial observation, considering that, in this (fictional and real) world, becoming an individual - and especially becoming a man - very much depends on one's ability to manage and, if need be, hide information about oneself. Mr Talboys seems to lack this ability, which makes him uncannily different, even almost inhuman: "The wintry day bore some resemblance to the man. [...] Like him, it was sharp, frigid, and uncompromising; like him, it was merciless to distress, and impregnable to the softening power of sunshine." (Braddon 1998: 186) The house's excess in orderliness is stressed repeatedly, and its immovability is associated with death: "The lawn was chiefly ornamented with dark, wintry shrubs of a funeral aspect, which grew in beds that looked like problems in algebra." (Braddon 1998: 187) The house and its master lack life and individuality, and the bell itself seems to be hostile towards the 'queer' and 'other' Robert, "as if it had been insulted by the plebeian touch of the man's hand" (Braddon 1998: 187). Braddon emphatically associates Robert "with a recognizable aristocratic 
type possessed of, by this historical moment, clear homosocial/homosexual overtones" (Nemesvari 2000: 114). In the eyes of a masculinity that Talboys mansion struggles to represent, he is deviant on the axes of both 'sexuality' and class: his masculinity is defined by his ambivalent status "as a member of an aristocratic family fulfilling the middle-class role of a barrister" (Nemesvari 2000: 114), and by his potentially deviant 'sexual' identity.

In all his lifelessness and stagnation, Mr Talboys efficiently exerts power over his domestic space, and especially over his daughter Clara, which is reflected in the unequal distribution of the ability to look: Mr Talboys notices everything, "as if he had eyes in the back of his head" (Braddon 1998: 189); "staring at the proceeding," and "his grey eyes fixed severely on his visitor" (Braddon 1998: 189; 190), he establishes a powerful physical presence. Clara, on the other hand, whom "the whole length of the room divided [...] from Robert" (Braddon 1998: 189), neither sees nor is seen properly in this scene: her "face dropped upon her clasped hands, and was never lifted again throughout the interview" (Braddon 1998: 194). In all their superficial impression of power, however, Mr Talboys' gestures remain empty performances. He acts out power without really possessing it. Robert is aware of this: "Had [he] been easily embarrassed, Mr. Talboys might have succeeded in making him feel so." (Braddon 1998: 190) Since he does not succeed, Harcourt Talboys leaves an impression on the reader of a suspended and stagnating masculine power that, in its striving for normativity, becomes ineffective. The performance of power loses meaning and remains an act, leaving Harcourt Talboys and his mansion without a name, and without significance.

While the indoors does not allow for any progress or self-realisation for the characters involved, the house's grounds, similar to the gardens at Audley Court, provide Robert and Clara with a space that opens them up, and triggers inner reflection and frankness. As Jennifer S. Kushnier observes, Robert's homoerotic search for George is paralleled by an attempt to 'normalise' his own 'sexual identity:' "Robert is [...] on a quest [...] to find a means by which he could 'become' heterosexual." (Kushnier 2002: 62) Moving away from a resurfacing of the homoerotic, the grounds at Halcourt mansion allow Robert to project his impossible desire for George onto a more normative object, a move that the nature of the house symbolically influences. On Robert's leaving the place, Clara runs after him and stops him, which makes Robert reflect on the unlikely possibility of a heteronormative encounter between this woman and his own, 'queer' self: "Is it me the flying female wants? [...] It is an age of eccentricity, an abnormal era of the world's history. She may want me." (Braddon 1998: 197) Clara observes both the stifling influence of the house, and the enabling nature of the outdoors: "How should I dare to betray my love for [George] in that house[...]? [...] Will you walk with me inside the plantation? [...] We might be observed on the high road.” (Braddon 1998: 199) 
It is exactly the in-between nature of the 'plantation,' on the margin between the (here emphatically normative) domestic and the public, that enables a strange energy between Robert and Clara. She re-ignites his passion in the search for George ("You will see vengeance done upon those who have destroyed him." [Braddon 1998: 200]), thus simultaneously pushing Robert to finally become the 'active male' (while herself remaining both "ostensibly passive under the rule of a dictatorial father" (Gilbert 1997: 95), and being the active instigator of this change in Robert), and confirming, indeed propagating his homoerotic desire for her brother. At the same time, he projects this desire onto her: "She was different from all other women that he had ever seen. [...] Clara Talboys was beautiful. [...S]he was so like the friend whom he had loved and lost." (Braddon 1998: 201; 203) Playing with underlying notions of same-sex and different-sex desire, neither option becomes clearly visible. In this scene with Clara and Robert, Braddon not only contrasts two characters who turn Victorian gender ideals upside-down - since Robert's "outstanding quality is his passivity" (Klein 2008: 163), and Clara displays 'masculine' activity and decisiveness - but also paves the way for the novel's 'queer' triangular solution that finally denies any definite identification of desire in a culture in which 'sexual identities' are increasingly defined and negotiated.

\section{The Crumbling Gothic: The Castle Inn}

The threat to masculinity that permeates Braddon's story becomes most palpable in one of the most notable architectures in Lady Audley's Secret, apart from Lucy's apartments: the crumbling, Gothic-like Castle Inn, which Lucy gives to Phoebe and Luke after their marriage. The wedding of this "very dim and shadowy lady," whose appearance blurs into "pale and uncertain shades," and who looks like "the ghost of some other bride, dead and buried in the vaults below the church" (Braddon 1998: 114), and "Mr. Luke Marks, the hero of the occasion" (Braddon 1998: 114) prefaces the description of the house with the backdrop of the traditional female Gothic, in which the man is master and hero (or villain), and the woman faces the threat of potential extinction. The context also, however, relocates this gendered Gothic conflict, away from the aristocratic, and into the realm of lower-middle-class business - the Castle Inn is, after all, a public house. Still, we find the same narrative techniques here that Braddon employs elsewhere to use the decay of the 'masculine' house as a metaphor of the flawed power of male Gothic domination: "It was not a pretty house to look at; it had something of a tumble-down, weather-beaten appearance, [...] a blighted, forlorn look. [...] The wind had had its own way with [it]." (Braddon 1998: 115) Verbs and adjectives of decay abound: "[B]roken and dilapidated, [...] tor[n] and scattered, [...] shattered, 
and ruined, and rent, and trampled upon[by the wind...,] the Castle Inn fell slowly to decay." (Braddon 1998: 115) The very material out of which the house was built seems to be lacking something, just as the house's 'master,' as it will turn out, cannot adequately occupy a position of representative power: "It seemed as though the wise architect [...] had taken especial care that nothing but the frailest and most flimsy material should be employed in its construction." (Braddon 1998: 134) So far, however, the loss of strength and power is only reflected in the 'performance' of the house's outer appearance. The business itself, the basis of modern, post-aristocratic, capitalist patriarchal power, is thriving: "[F]or all that it suffered without, it was not the less prosperous within doors." (Braddon 1998: 115)

Braddon constructs this place as one of the only domestic sites in the novel in which power is actually fought over indoors - most other conflicts are taken into the liminal outdoors. The Castle Inn will prove to be a house in which one of the novel's 'patriarchs' almost meets his own destruction, and another actually loses his life in Lucy's fight for power. Foreshadowing the danger ahead, the narrator comments, on Roberts arrival at the Castle Inn, that "it was rather a strange fancy of the young barrister to prefer loitering at this dreary village hostelry" (Braddon 1998: 134); and, indeed, Robert's staying there while plotting to find out more about Lucy's secret past places him under the scrutinising gaze, the "active, searching glance" (Braddon 1998: 136), of Lucy's female helper and homosocial companion, Phoebe: "If there's any bad meaning in his coming here, [...] my lady will know of it in time." (Braddon 1998: 135) Robert is observant enough to realise the potential role Phoebe could play in the power struggle over the management of knowledge: "That [...] is a woman who could keep a secret. [...She] would be good in a witness-box, [...] it would take a clever lawyer to bother her in a cross-examination." (Braddon 1998: 136) Phoebe's elevated and potentially powerful position within the house is emphasised by "the vague air of refinement that pervaded her nature" (Braddon 1998: 138). She is worried about her husband's inability to contain secret knowledge as well as she does, displaying "an expression of anxiety [...] as she glanced from Mr. Audley to Luke Marks" (Braddon 1998: 138). Luke is very much aware that, in her control over knowledge, Phoebe is superior to him: "I suppose you don't want me to open my mouth to this gent. [...] You're always putting in your tongue and clipping off my words before I've half said 'em." (Braddon 1998: 139)

Fittingly, it is here that Lucy and Robert have one of their rare confrontations. After initially putting on the act of civility that they are used to performing at Audley Court, with Lucy acting like "a childish, helpless, babyfied little creature" (Braddon 1998: 141), and Robert insisting that maybe he "should be out of the house" (Braddon 1998: 142), they both rise to a level of frankness that, at other points of the narrative, they only manage in the outdoors. Robert voices anxieties 
about domestic spatiality and its relation to secrets that infuse the whole genre of sensation fiction, and reflect a typically modern preoccupation with spatial privacy and secrecy: "What do we know of the mysteries that may hang about the houses we enter? [...] Foul deeds have been done under the most hospitable roofs, terrible crimes have been committed amid the fairest scenes, and have left no trace upon the spot they were done." (Braddon 1998: 143) The public, yet domestic space of the Castle Inn is the place in which the novel's antagonists' conflict becomes most explicit - before Lucy's confession leads the narrative towards its conclusion.

The Castle Inn is also the space in which Lucy attempts her last destructive blow on Robert, who threatens to expose her secret. On her arrival at the inn in the middle of the night, the weak standing of masculinity in the face of female power is strongly suggested by phallic imagery: "The cruel blasts danced wildly round that frail erection. They disported themselves with the shattered pigeon-house, the broken weathercock, the loose tiles and unshapely chimneys." (Braddon 1998: 314) Lucy's power in this scene is further foregrounded by her uncanny, and strongly gendered impression on Luke, the house's nominal 'master:' she "awed him into silence by the unearthly glitter of her beauty. [...] There was another flame in her eyes - a greenish light, such as might flash from the changing hued orbs of an angry mermaid." (Braddon 1998: 316) Lucy becomes the supernatural female who has come to tear down the house of patriarchy. In a highly symbolic act, she takes charge of the house's spatiality by literally turning the key on Robert: "[S] he turned the key in the lock; she turned it twice, double locking the door." (Braddon 1998: 318) Lucy here reverses the Gothic theme of the locked-in woman, and becomes the female Bluebeard, almost succeeding in destroying Robert, and the threat he poses to her. While Luke, the weak and inadequate master and husband, gets fatally wounded in the fire that Lucy allows to break out from the innermost female space of the inn (Phoebe's dressing room), Robert manages to escape. A1though Braddon goes very far in dethroning patriarchal power, reflected in both the construction of her characters, and their (inter)actions in space, she stops just before this power is actually broken. Adhering to the rules of the sensation genre, and the expectations of her readership, Braddon cannot let Lady Audley succeed, but she has her go very far.

\section{Heterotopian Spaces: The Homoerotic Chase}

Aside from the heterotopian surroundings of Audley Court, which both enable action, and destabilise established power structures, Braddon, in this novel, constructs a striking number of liminal spaces when the domestic is not the centre of attention. These spaces, most of the time, serve to illustrate the relationship 
between Robert Audley and George Talboys, a relationship that Braddon makes deliberately hover constantly on the fine line between homosocial and homosexual, constructing a form of desire that makes Robert, Lucy's main male opponent, just as deviant and 'closeted' as Lucy herself. Robert's chase after George, and his attempt to get at Lucy's secret also fundamentally serve to define him as a 'man,' oscillating between the conspicuous performativity of the dandy (especially at the beginning of the narrative), and the more subtle performativity of the gentleman of honourable motives (as the 'saviour' of Sir Michael and George) (cf. Heinrichs 2007: 105-108).

The reader first encounters George Talboys on board a ship, a space that strongly associates his character with the homosocial environment of sailors, and its queer potential. Braddon constructs him as "a very attractive but rather androgynous individual" (Klein 2008: 163), and an object of desire for both the female-heterosexual, and the male-homosocial/homoerotic gaze of the ship's passengers: with his "handsome brown eyes, with a feminine smile in them, [...] tall, and powerfully built[..., everybody liked him" (Braddon 1998: 18-19). In contrast, the way George talks about his wife makes her more of a child-like doll than an object of his desire: "My pretty little wife! [...M]y little darling. [...M]y pet." (Braddon 1998: 23) George is immediately marked as occupying a position of desired object rather than desiring subject, and it is Robert who will come to desire him most.

Braddon foregrounds Robert's desire for George through Robert's repeated 'closet' rhetoric, a temporary displacement of desire onto George's sister - as demonstrated above - and a spatial displacement of Robert into increasingly heterotopian spaces in his eroticised search for his friend. In the course of the novel, the narrator repeatedly stresses Robert's curious disinterest in his cousin Alicia's attraction to him: "[I]f poor Alicia for a moment calculated upon arousing any latent spark of jealousy lurking in her cousin's breast [...], she was not so well acquainted with Robert Audley's disposition as she might have been." (Braddon 1998: 63) Employing this strategy, Braddon stresses "[t]hat Robert prefers a male rather than a female mate" (Kushnier 2002: 65). Additionally, several passages explicitly refer to Robert himself wondering about his 'strange' affection for George: "[H]ere he was, flurried and anxious, bewildering his brain by all manner of conjectures about his missing friend. [...] 'And to think that I should care so much for the fellow!'” (Braddon 1998: 84; 97)

Spatially, the displacement of homoerotic desire is reflected in a movement away from the patriarchal and the domestic into liminal, heterotopian spaces. The first of these movements takes place when Robert, who is introduced as "a rather curious fellow" (Braddon 1998: 35), and "the descriptions of [whose] demeanor characterize him as a rather effeminate gentleman" (Kushnier 2002: 66), meets George in London. Telling Robert about his wife ("The idea of your having a wife, 
George; what a preposterous joke.” [Braddon 1998: 38]), George constructs a triangular relationship that negotiates the desire between the two men through his wife: "I shall take a villa on the banks of the Thames, Bob [...]; and we shall have a yacht, [...] and you shall lie on the deck and smoke while my pretty one plays her guitar and sings songs to us." (Braddon 1998: 38) Shortly afterwards, however, George learns of his wife's death, and the triangular fantasy is - for now - broken. While their relationship, un-mediated through a woman, cannot grow beyond careful physical expressions of intimacy (Robert "lay[] his hand gently upon the young man's arm" [Braddon 1998: 41].), they go to Lucy's grave at Ventnor together. Here, in the doubly liminal space of the churchyard by the sea, the men, on a very subtle level, seem to grieve not only for the 'pretty wife's' death, but also for the death of their triangular fantasy.

This first movement is paralleled later in the narrative after George has disappeared, and Robert goes searching for him. Alicia mocks Robert, who is "much preoccupied with the one idea of looking for his friend" (Braddon 1998: 85), for this seemingly obsessive friendship: "Pythias, in the person of Mr. Robert Audley, cannot exist for half-an-hour without Damon, commonly known as George Talboys." (Braddon 1998: 87) The reference to Greek mythology adds to the homoerotic undertones of her remark. Following George's traces from his rooms in London, Robert again moves towards the sea, to Southampton, and the further he gets, the more his mind revolves around his friendship with George: “"It isn't kind of George Talboys to treat me like this.' But even at the moment that he uttered the reproach a strange thrill of remorse shot through his heart." (Braddon 1998: 95) Again, it is a physical reaction that makes the reader aware that there must be more to this friendship than is openly admitted. Linguistically, Robert's questions dominate this scene: "What can be the meaning of all this? [...] What can be the meaning of all this? [...W] hat is the meaning of this?" (Braddon 1998: 95; 98) Physically, Robert moves towards the enabling possibilities of heterotopian spaces, while mentally, he is stuck in a state of disavowal. The space associated with Robert is full of 'closets.' After George's disappearance, he keeps all the documents he collects regarding his friend in a cabinet which he keeps locked at all times (cf. Braddon 1998: 157). George's past, too, becomes associated with a locked trunk he keeps in Robert's rooms. This trunk Lucy breaks into with the help of a blacksmith to steal evidence of her being George's wife (cf. Braddon 1998: 149-53), and Robert later opens it to get close to his allegedly dead friend by "handl[ing his] things with a respectful tenderness, as if he had been lifting the dead body of his lost friend" (Braddon 1998: 157).

Robert's spatial displacement is taken up again much later in the narrative when he goes to the town in which George had met his wife. Wildernsea turns out to be another "seaport town" (Braddon 1998: 239), with "a melancholy [train] 
station" in "a sandy desert" (Braddon 1998: 240). Gloomy, rough, and decaying, this is another heterotopian space in which Robert will get closer to discovering his vanished friend. It is striking that the homoerotic search for George can only be accomplished with the mediating help of a woman: the only person at Wildernsea who has knowledge that will be useful to Robert is "Mrs. Barkamb[..., the person who owns No. 17, North Cottages, the house in which Mr. Maldon and his daughter lived" (Braddon 1998: 243). Robert, a man increasingly associated with the liminal and the outdoors, needs the help of a woman of property who rules over the domestic. That this is indeed a notable unbalance of power is confirmed by George's dream immediately before his visit to Mrs. Barkamb's house:

"[H]e saw Audley Court, rooted up from amidst the green pastures and the shady hedgerows of Essex, standing bare and unprotected upon that desolate northern shore, threatened by the rapid rising of a boisterous sea. [...] As the hurrying waves rolled nearer to the stately mansion, the sleeper saw a pale, starry face looking out of the silvery foam, and knew that it was my lady, transformed into a mermaid, beckoning his uncle to destruction." (Braddon 1998: 244)

It is worth quoting this passage in such detail because it illustrates one of the novel's central anxieties. Through Robert's dream, Braddon shows that Lucy's power over her husband's 'mansion' threatens the whole 'house' of patriarchal power relations. Robert's daydream a few pages later mirrors this misogynistic anxiety. Walking thorough Audley churchyard, he reflects: "If my poor friend, George Talboys, had died in my arms, and I had buried him in this quiet church, [...] how much anguish of mind, vacillation, and torment I might have escaped.” (Braddon 1998: 254) In this morbid fantasy (not coincidentally set in another heterotopia of most final, indeed fatal, possibility), Robert realises the impossibility of his desire, and its incompatibility with the structures and ideals he strives to represent. His problem is that patriarchy at once expects him to prefer homosocial over heterosexual bonds, while, at the same time, denying homosexual desire. Braddon, hence, in juxtaposing Robert's fear of Lucy's uncanny femininity with his homosocial/homosexual dilemma, exposes patriarchal society to be simultaneously misogynistic, intensely homosocial, and excessively homophobic.

In the end, Robert fails to perform any stable gender identity, a fact that is reflected in his spatial positioning in liminal spaces. Robert's role as detective, unravelling secrets he seems to see everywhere, makes him the prototypical 'paranoid reader.' Braddon, as Emily L. King points out, structures her novel such that it questions just these paranoid reading practices, which become especially sig- 
nificant in a time during which the reading of the 'open secret' of a newly defined (male-)'homosexual' identity comes to be equated with paranoia as such:

"Within the totalising system of paranoia, nothing is always made into something by both paranoid characters (the 'amateur-detective hero') and by literary critics alike. Lady Audley's Secret demonstrates the problems with such a system of interpretation, particularly when nothingness is deliberately employed to bring about a specific something." (King 2008: 59)

I argue that this critique of such defining paranoid readings is also reflected in the way Braddon contrasts Robert's search for definite meaning with spaces that defy just such a teleological approach to interpretation, and pave the way to a more open, non-definite 'queer' reading of Braddon's text. She conspicuously employs the language of the 'open secret,' and combines it with an agglomeration of heterotopian spaces in order to hint at possible 'paranoid' interpretations, without ever making those readings explicit. The eroticised relationship between Robert and George, hence, never becomes 'homosexual,' but allows for the 'queer' - as opposed to the paranoid - reader to experience the pleasure of maybe 'knowing,' "knowing without the desperate search for evidence to confirm one's pre-existing belief" (King 2008: 68).

\section{The 'Closet' of Patriarchy: Villebrumeuse}

In the narrative's solution, Braddon exposes patriarchal masculinity as a pathological construct that, while finally regaining control over the subversive female, only adds to the supressed secret structures that make up the precarious foundation of its power. Shutting Lucy away in an asylum in Belgium displaces and confines her spatially and mentally, only to make her part of an increasingly 'closeted' culture of masculinity. The underlying fears and anxieties of these structures become visible in Robert and the doctor's 'discreet' treatment of the case: Robert's 'greatest fear is the necessity of any exposure - any disgrace" (Braddon 1998: 372), and the doctor agrees "to assist [...] in smuggling her away out of the reach of justice" (Braddon 1998: 372). Robert's fear of exposure is the same basic fear that lies at the heart of the Gothic, and of any Bluebeard tale: his anxieties border on paranoia, because the protection of his 'reputation,' and the keeping of his secrets form a vital part of his masculine self-definition.

Braddon has Robert appeal to a doctor and modern medical discourse, one of the great pillars of society, to achieve his goal. The doctor diagnoses Lucy's sub- 
versive actions as deviant and dangerous, and makes explicit the necessity to make her part of the 'closet of society:'

"From the moment in which Lady Audley enters that house, [...] her life, so far as life is made up of actions and variety, will be finished. Whatever secrets she may have will be secrets forever! Whatever crimes she may have committed she will be able to commit no more. [...A]s a physiologist and as an honest man I believe you could do no better service to society than by doing this." (Braddon 1998: 373-74)

Considering Lucy's powerful position that is established in the course of the story, the threat she poses to the men surrounding her, her own implausible self-denunciation, and the increasingly weak position of the male characters, it becomes clear that what, on the surface, seems to be the just punishment of a criminal is actually Braddon's subtle making visible of the structures of paranoid masculinity.

Braddon does not construct the madhouse itself as an architecture representing a system of powerful patriarchal justice either. Instead, it both stands for the lost power of a nostalgic past of patriarchal strength (Villebrumeuse is "an old ecclesiastical town," but now "a forgotten, old world place" [Braddon 1998: 377].), and is a liminal, marginal space, "darker rather than lighter, [...a] remote [...] city [... that] bore the dreary evidence of decay [...] on every [...] feeble pile of chimneys" (Braddon 1998: 377). This place, while serving as the space in which the men can shut away what threatens them, is simultaneously slippery, and beyond their reach of control, a giant 'closet' space that can never be safely relied on. The same holds for the madhouse itself: its lighted windows "looked out like the pale eyes of weary watchers" (Braddon 1998: 379). Panoptic control, in this place, is no longer alert and awake, but has grown tired.

The madhouse does, however, serve the narrative's purpose of eliminating Lucy's presence, reducing her to a nameless "No. 14" (Braddon 1998: 381), enabling Robert, by ensuring him of the temporal containment of his secret, to fantasise about an unmediated homosocial friendship with George, unthreatened by Lucy's existence: "Mr. Audley appeared suddenly to have forgotten that he had ever heard any mortal appellation except that of himself and his lost friend." (Braddon 1998: 381) The madhouse also causes contradictions in the characters' psychology to surface. Spatially, this is reflected in the strange in-between position of the house's interior, which oscillates between the domestic, the terrorising Gothic, and the heterotopian. It contains "a stately suit of apartments" that is, however, "of a dismal and cellarlike darkness; a saloon furnished with gloomy velvet draperies, and with a certain funeral splendour;" and "a bed-chamber, containing a bed so wondrously made, as to appear to have no opening whatever in its coverings" (Braddon 1998: 
381). Seductive and life-threatening, dead and alive, this is a dream-like space that defies any final definition, and in which power relations, while obvious on the surface, become precarious and uncertain on closer observance.

This also becomes apparent in Lucy's not having completely lost control over space. While she cannot fight her spatial confinement within the architecture of the madhouse ("[U]nder no circumstances was she to be permitted to leave the house and grounds without [...] protection." [Braddon 1998: 382]), she nevertheless still displays a certain amount of command over the 'domestic' space that she is now to live in, a fact highlighted by Braddon's unexpected use of the present tense: "Madame rises suddenly, erect and furious, and dropping her jewelled fingers from before her face, tells [Monsieur Val] to hold his tongue. 'Leave me alone with the man who has brought me here[....] She points to the door with a sharp imperious gesture." (Braddon 1998: 383) Similarly, although she clearly sees that Robert has "brought [her] to a living grave" (Braddon 1998: 384), she controls Robert's movements in this scene: "[S]he held her place by the door, as if determined to detain Robert as long as it was her pleasure to do so.” (Braddon 1998: 385) Although Lucy is obviously defeated, and her power is broken, Braddon, through detailed and subtle descriptions of the spatial properties of Villebrumeuse, and the characters' movement within this space, conveys a sense of unease that unsettles the newly established power relations, and leaves the reader positively dissatisfied with the pathological shutting away of female subversive energies in a space that itself lies beyond patriarchal control.

\section{Precarious Peace in a Queer Space: The Ending}

It is worth giving a few thoughts to the way Braddon constructs the ending of Lady Audley's Secret, because it leads the novel's conflicts concerning gender and desire to surprising conclusions. Although, ostensibly, patriarchal order is re-established, and the deviant woman punished, the novel's last few pages are so full of unlikely turns that it is obvious that Braddon questions her own 'happy ending,' which the conventions of the genre dictate her to provide. There is no doubt that the men have achieved their goal of disempowering Lucy, and displacing her both spatially and mentally. Robert returns to Audley Court "without the woman who had reigned in it for nearly two years as queen and mistress" (Braddon 1998: 388), and Sir Michael has the "earnest wish never again to hear that person's name. [...] I seek to know no more" (Braddon 1998: 391). However, although Robert still tries to project his desire for George onto Clara ("[T]he new strength and friendship for the murdered man grows even stronger as it turns to you [Clara], and changes me until I wonder at myself." [Braddon 1998: 394]), he cannot achieve this change 
because "[t]he shadow of George Talboys pursued him" (Braddon 1998: 397). Robert can neither deny his desire for George, nor redirect it according to the rules of heteronormativity. He is also confronted with finding that other men seem to know his 'sexual' secret. The dying Luke calls Robert to his bedside, and employs the language of the 'open secret' to allude to Robert's deviant desire: "You was uncommon fond of that gent as disappeared at the Court, warn't you, Sir?" (Braddon 1998: 405) The conversation between the two men is a bravura piece of 'you know what I mean'-rhetoric. Both men speak of a secret that Luke has kept, but while Robert thinks he knows its content, Luke denies this: "[S]uppose my lady had one secret and I another. How then?" (Braddon 1998: 406) While it later becomes clear that Luke is referring to his knowledge of George's still being alive, the effect of this rhetoric in the context of Robert's 'fondness' of George is ambiguously sexualised. This becomes even more apparent when, as Luke finally tells Robert how he helped George, he describes a scene of almost erotic homosocial intimacy: "I got his clothes off him how I could, for he was like a child in my hands, and sat starin' at the fireplace as helpless as any baby; [...] nobody was to know of his bein' there except us tow." (Braddon 1998: 416)

With George being alive after all, Robert is still denied fulfilment of his desire for the other man. It would, however, be a simplification to say that "through his conflict with, and destruction of, Lady Audley, Robert determines his 'proper' place on the sexual continuum and therefore learns to 'go straight"' (Nemesvari 2000: 110). Instead of erasing homoerotic desire from her narrative and confirming heteronormative ideals, Braddon achieves a middle way: while Robert claims that Clara is "the woman he loved" (Braddon 1998: 427), it is actually the presence of George that "was always a bond of union between them" (Braddon 1998: 430). "Clara ultimately serves as a commodity to be exchanged;" (Kushnier 2002: 69) and, indeed, when George returns to England, the three of them start a life together as an idealised erotic triangle in the heterotopian environment of "a fairy cottage[..., ] a fantastic dwelling-place of rustic woodwork" (Braddon 1998: 435). A place like this and a life like this, which enable Robert to "be with George in a socially acceptable way" (Kushnier 2002: 69), belong to the realm of the fantastic, as Braddon must be aware. It is, however, crucial that she creates a space of 'queer' possibility at the end of her narrative, "destabiliz[ing] the heterosexual norm of [the novel's] closure" (Nemesvari 2000: 120). This space stands in stark contrast with the failed, traditionally patriarchal architecture of Audley Court, which "is shut up, and a grim old housekeeper reigns paramount in the mansion which my lady's ringing laughter once made musical. [...P] eople admire my lady's rooms, and ask many questions about the pretty fair-haired woman, who died abroad." (Braddon 1998: 436) Braddon succeeds in creating a subtle portrayal of mid-nineteenth-century occupations with gender, and a "resulting crisis of masculinity. [... 
She] finds deviance at the heart of masculinity, and, subsequently, at the heart of Victorian social authority." (Heinrichs 2007: 103; 118) 


\section{Globalising the 'Closet:' Henry James}

\section{Masculine Disempowerment in a Woman's Mansion: Henry James' “The AsPERN PAPERS"}

Henry James' tale "The Aspern Papers," first published in 1888, tells the story of an unnamed male editor who is obsessed with the desire to find a lost compilation of letters by the poet Jeffrey Aspern. He assumes them to be in the possession of Juliana Borderau, who, together with her niece, lives a quiet life of old age in a Venetian palazzo. The editor pays the two women a visit under a false name, and a subtle power struggle ensues. The focus of this analysis will be on the three most prominent spaces in the story, namely the house itself, its garden, and Venice, the story's background setting. Reading the tale through the lens of a politics of secrecy and the 'closet,' I will demonstrate how James turns traditional notions of domestic power relations upside-down, making his protagonist desperately try to penetrate a domestic space that promises to hold a secret which, at the same time, he constructs himself in a 'paranoid reading' of his dealings with the two women. The editor increasingly eroticises the 'open secret' of the fetishised letters as a substitute for his unlivable homoerotic desire. It is fitting that James chooses the image of the letter as the focal point of this desire. In Victorian England, as Kate Thomas observes, the expanding postal system produced its own enabling myths: "A dominant fantasy [...] was that when you posted a letter, that letter took you [to] places otherwise out of bounds to you, in the close company of a vast miscellany of others. You extended yourself through the post-letter's exploits and got to experience an exuberant displacement of subjectivity." (Thomas 2012: 2)

Imagining his desire through the virtual presence of a dead poet in his letters, the editor displaces it temporally and spatially, and the letters come to stand for the knowledge of desire as such. Throughout the story, the female characters remain firmly in control of the power over knowledge, symbolised and embodied by Aspern's letters; or, as Joseph Church puts it in his psychoanalytical reading of the tale, "[t] he phallus [...] is in the wrong place. [...] To take possession of the letters [...] would signify [the editor's] return to a position of mastery." (Church 1990: 28) 
In this, however, the editor does not succeed. Instead, in his emphatic and repeated refusal to buy into the economy of heterosexual triangulation of his homoerotic desire for the dead poet, he increasingly occupies liminal spaces that can only seemingly get him closer to what he wants. Faced with both a spatial displacement of his body out of the realm of influence and power, and a linguistic displacement of his desire out of the realm of the sayable, the editor struggles to define himself in a fictional world in which masculinity "and the male body [...itself are] unreachable, undefinable, and unsayable” (Reesman 2001: 43).

\section{Female Domestic Secrecy: The Borderau Palazzo}

The reader encounters the Borderaus' house in an account the editor gives of his first impression of it: "Jeffrey Aspern had never been in it that I knew of; but some note of his voice seemed to abide there by a roundabout implication, a faint reverberation." (James 2003a: 54) Significantly, the editor immediately identifies the house with the admired poet, whose only connection with the palazzo is an assumed acquaintance with the house's mistress. The editor projects his abstract (and multiply unlivable) desire for the dead poet onto the actual space of the house. This is further emphasised when he admits that he "adored the place" because

"that spirit kept me perpetual company and seemed to look out at me from the revived immortal face - in which all his genius shone - of the great poet who was my prompter. I had invoked him and he had come; he hovered before me half the time; it was as if his bright ghost had returned to earth to tell me that he regarded the affair [of the letters] as his own no less than mine and that we should see it fraternally, cheerfully to a conclusion." (James 2003a: 75)

In his obsession, the editor constantly feels the presence of Jeffrey Aspern. He even has imaginary conversations with him, and assigns meaning to the things belonging to the house only in connection with the poet. Not only does he "feel a certain joy at being under the same roof with" the "sacred relics" (James 2003a: 76), the letters, of which he does not even know for certain whether they really are in this house, but he also sees Aspern through the house's actual mistress, Juliana, in that, when he encounters her for the first time, he feels "an irresistible desire to hold in [his] own for a moment the hand that Jeffrey Aspern had pressed" (James 2003a: 69). Wishing to get close to a poet who has been long dead, the editor tries to reach him through people and objects existing in the present. He instinctively triangulates his desire for the dead man through the old woman: "Her presence seemed somehow to contain his, and I felt nearer to him at that first moment of 
seeing her than I ever had been before or ever have been since." (James 2003a: 64) Eroticising the relationship between Juliana and "the scholarly artifact [...] as homosocial fetishized exchange object" (Hoeveler 2008: 125) - Aspern's letters and his portrait - the editor becomes her rival over the dead man's love: "I had an idea that she read Aspern's letters over every night or at least pressed them to her withered lips. I would have given a great deal to have a glimpse of the latter spectacle." (James 2003a: 71) The relationship between the editor and Juliana is, hence, immediately marked as heterosocial. Simultaneously, he reduces the old woman - whose last name's etymology alludes to an inventory or list of things - to a mere object, the receptacle that holds the letters he wants: "In choosing to name Jeffrey Aspern's paramour 'Bordereau,' James himself participates in his publishing scoundrel's transgressions against the woman, reducing her to an object." (Monteiro 2009: 34) As voyeur and misogynistic rival, the editor, however, needs Juliana and the ensuing triangular dynamics to make sense of a desire that is itself unnameable. James, naturally, denies him any fulfilment of this desire, and this denial is expressed on various levels. The editor can only fetishise his homoerotic feelings for Aspern, and project them onto the poet's surviving letters, his being dead emphasising the impossibility of such a desire; a heterosexual triangulation of this unliveable passion - although initially suggested - is also, however, foreclosed, because both Juliana and, as we shall see later, Tita are impossible love objects for the editor. "[W]oman "for him not as an object of desire in her own right but as a conduit of desire between two men." (Veeder 1999: 27) Negotiating his desire and relationships firmly on the axis homoerotic/heterosocial, as opposed to the normative mirror variant heteroerotic/homosocial, the editor fails to successfully establish a stable gender and 'sexual' identity for himself.

The tale's spatial organisation prominently reflects its preoccupation with deviant and 'lacking' masculinities. While everything in and about the house becomes a metaphor for the dead male poet, and the editor's desire for him, the masculinity that the house represents is not associated with strength and virility, but with fading glory. Approaching the palazzo in a gondola, the editor perceives it to have "an air not so much of decay as of quiet discouragement, as if it had rather missed its career" (James 2003a: 57). This is not what one would expect of a building that was intended by its original owner to represent the strength and power of the male lineage. The house even seems to be half forgotten by the inhabitants of the neighbourhood. Mrs Prest, who lives there herself, has the impression that "though you can pass on foot scarcely any one ever thinks of doing so" (James 2003a: 57). The editor admits that the house looks "impressive," but also "cold and cautious" (James 2003a: 60). Some of the old pride seems to be left, but only a shadow of it. When he first enters the house, and stands in the hall - the hall traditionally being the most representative space of a mansion, in which the male owner displays his 
power and influence - it seems to him "gloomy and stately" (James 2003a: 60), in itself an apparent contradiction, but again emphasising the shadow of past pride in today's decay: the hall is stately mainly due to its "noble shape" and the "fine architectural doors" (James 2003a: 60). The original intention for the place to represent its owner's power is still visible as though through a mist. The rooms are "dusty," and "disfigured with long neglect" (James 2003a: 70). One should keep in mind, however, that this is only the impression the editor gets of, firstly, the public, representative parts of the house, and, secondly, those private areas of it that are not inhabited by the two women. Those areas of the palazzo that are, in terms of traditionally gendered domestic spatiality, connoted masculine - like the hall, and basically every part of the house which is not a private room of either Juliana's or Tita's - seem to have lost their masculine, representative strength. It is striking that the editor explains this condition of the house as "a sign that Juliana and her niece (disenchanting idea!) were untidy persons" (James 2003a: 71), immediately assuming an attitude that assigns the role of housekeeper to the women, not asking after the reasons for the untidiness, or the position of a woman as head of the house instead of overseer of the household and its keeping. The Borderaus' refusal to keep the house's 'masculine' spaces in good condition can, in fact, be understood as a deliberate denial of the public display of masculine self-representation.

While the editor thus assumes an implicitly sexist attitude towards the two women, several passages in the story point to the fact that he feels threatened and demasculinised by them, and in relation to the house they inhabit. He is constantly afraid of being put in a 'feminine' position, which becomes most obvious when Mrs Prest accuses him "of wasting precious time in her salon when I ought to have been carrying on the struggle in the field" (James 2003a: 73). Both Mrs Prest and the editor assume the salon - in its function as the room where mixed gendered groups have tea and pleasant conversation - to be a place not suitable for a man who takes his task (and his masculinity) seriously. The constant company of women demasculinises the editor. In order to escape this threat, Mrs Prest advises him to continue "the struggle in the field," that is outside the house, in a public space, the only space where men can really be properly 'masculine.'

The editor's fear of demasculinisation is also repeatedly revealed in his emphatic need to dissociate himself from domesticity. When he questions his servant about his hostesses' habits, trying to pick up gossip, he not only claims that "I did what I disliked myself for doing" (James 2003a: 74), but also explicitly denies any part of his own in domestic talk amongst servants: "It was not for me of course to make the domestic tattle, and I never said a word to Miss Borderau's cook." (James 2003a: 75) He is equally eager to keep his relations with the Borderaus on the level of business, not only to disguise his romantic obsession with the dead poet, but also to emphasise his ability to be a man of business. Ironically, while business trans- 
actions are traditionally carried out in either a public, 'masculine' (for example the library), or an intimately homosocial space (the closet), Juliana forces the editor to come into her private apartments to talk about business, confirming her status as equal counterpart in their heterosocial relationship. Doing masculine business in a feminine environment: a highly ambiguous position for the editor, whose main concern is to prove his own masculinity normative and stable.

The two women and the house do nothing, however, to strengthen the editor's masculinity. On the contrary: considering the importance of the gaze in gendered power relations, it is crucial to observe that the editor is repeatedly deprived of his right to look. Instead, the women, especially Juliana, make him the object of a scrutinising female gaze that he cannot set anything against. Juliana, her "green shade" (James 2003a: 65) covering her eyes, making it impossible for the editor to make her out properly, puts herself in a position in which "from underneath [the shade] she might scrutinize [him] without being scrutinized herself" (James 2003a: 65). Although it never becomes clear whether Juliana is blind or not (her niece claims that she is), the explicitness of this unequal distribution of the gaze is striking: "I want to be where I can see this clever gentleman. [...] I want to watch you - I want to watch you!" (James 2003a: 106) As William Veeder puts it, "[not] only can [the editor] not penetrate women, but they can penetrate him" (Veeder 1999: 24). Similarly, the house's closed windows and shutters constantly make the editor unsettlingly aware of the possibility of being watched by the women without being able to look at them himself; and although, towards the end of the tale, he tries to reclaim his masculine authority by "turn[ing] [his] eyes all over [Juliana's] room, rummaging with them the closets, the chests of drawers, the tables" (James 2003a: 109), imagining a penetrative invasion of her most private spaces, "allowing his eyes to function as an expression of a traditionally masculine species of affront" (Mengham 1997: 49), he is ultimately denied the actual (sexual) penetration of these private spaces.

In his final encounter with Juliana, in fact, her shaming gaze keeps the editor from penetrating her 'closet,' which supposedy holds the Aspern Papers, the object of the editor's desire. James clearly makes Juliana mistress of the management of the 'closet,' in that she knows both how to use a rhetoric of secrecy as an instrument of (heterosocial) power, and how to take advantage of the editor's paranoid tendency to read everything that happens in the house in relation to his search for the lost documents. He can only make sense of his environemt in terms of the politics of the 'closet.' Without having any proof, he assumes that the women's denial to posses any documents relating to Jeffrey Aspern (cf. James 2003a: 58) must mean the opposite, namely that their denial is proof of their having those documents. Although the narrative makes it appear likely that the two women do have something belonging to Apsern, it is mostly the narrator's paranoid predis- 
position that reads a secret where none might be: "Miss Borderau's secrets were in the air. [...T]he two ladies passed their days in the dark. But this only proved to me that they had something to conceal." (James 2003a: 76) Miss Tita, in her unsuccessful attempt to awaken heterosexual interest in the editor, takes up his rhetoric of secrecy, and tries to use it to her advantage by fuelling his fantasies, and making herself his secret sharer, to the exclusion of her aunt: "I have told her nothing." (James 2003a: 89) What Tita does not see, but the reader becomes aware of, is, of course, that she overestimates the heterosexual effect of her heterosocial bond with the editor. He really only takes an interest in her as long as she stands in as the female part of the triangle in his search for the documents that represent his homoerotic desire.

Juliana, more of an expert than her niece in the management of knowledge, is also more ingenious in her employment of a rhetoric of the 'open secret.' Not only does she conciously keep the editor ignorant of what exactly it is she might know (or not know) about the (possibly existing) Aspern Papers, but she also knows how to play with the editor's paranoid tendencies. When Tita tells him that her aunt "wants to talk with [him] - to know [him]" (James 2003a: 89), this immediately triggers a paranoid reaction in him: "I ceased on the spot to doubt as to her knowing my secret. [...T]he old woman's brooding instinct had served her; [...] she had guessed." (James 2003a: 90) The 'closet-watching' between the editor and Juliana, hence, is mutual: while he tries to penetrate Juliana's heterosocial 'closet' (which, supposedly, contains Aspern's letters), she, through her rhetoric, makes the editor aware that she knows of his homoerotic 'closet' (his desire for Aspern). While, however, Juliana's secret is firmly embedded in the structures of her house, the editor's 'closet' does not have a space to contain it. It is a 'houseless closet,' and the editor fails to protect it from Juliana's knowing gaze. For him, she symbolises the threat of heteronormative policing, both through what he imagines, and through what she actually says. He is constantly afraid that Juliana might burn the papers he is convinced she possesses, an act that would symbolically put a violent end to his homoerotic fantasies. Juliana also explicitly questions the editor's masculinity when she criticises his fondness of flowers, a fondness that, at the turn of the twentieth century would clearly have been associated with notions of effeminacy and decadence: "It isn't a manly taste to make a bower of your room." (James 2003a: 90)

The editor's incessant paranoid readings of all of Juliana's actions suggests that he actually enjoys the game the two of them create between themselves. Juliana's "wish to sport with me that way simply for her private entertainment - the humour to test me and practise on me" (James 2003a: 104) - becomes a challenge for him, a challenge, in fact, that is indispensable for the articulation of his desire for Aspern: only by telling himself, in relation to Juliana's portrait of Aspern, that "[w]hat she 
wished was to dangle it before my eyes and put a prohibitive price on it" (James 2003a: 104) can he allow himself to express that it "represent[s] a young man with a remarkably handsome face" (James 2003a: 104). Only by participating in a heterosocial power struggle that threatens the stability of his own gender identity can the editor experience the thrill and joy of almost having his unacknowledged homoerotic desire fulfilled. The very impossibility of an actual fulfilment of this desire makes its torturing articulation as obscure, as secret itself desirable to him.

The rhetoric and symbolics of the 'closet' that James evokes in this tale cannot be read in a linear fashion. They are multiplied, and contradict, but also complement each other. The editor's 'closeted' desire is mirrored in his wish to penetrate the actual 'closet' space of the house in which he assumes the object of his desire to be hidden. Evoking an imagery of Gothic spatiality, James constructs the house's most secret space (Juliana's apartment) as the physical destination of the editor's search: the documents "were probably put away somewhere in the faded, unsociable room. [...I] noticed that there were half a dozen things with drawers, and in particular a tall old secretary, $[. .$.$] a receptacle somewhat rickety but still capable$ of keeping a secret." (James 2003a: 107) Still without definitely knowing whether or not he is guessing correctly, the editor obsessively fixes his wish to penetrate on this piece of furniture: "[A] simple panel divided me from the goal of my hopes." (James 2003a: 107) Tita, aware of this fixation, plays with it, and directs the editor's gaze to "a queer, superannuated coffer" (James 2003a: 110), claiming that "[t]hose things were there" (James 2003a: 110). Deliberately confusing the editor both spatially and temporally about the whereabouts of the object he desires, Tita tries to prolong her hold on him. Although the editor is perfectly aware of the possibility of there not actually existing any documents at all (cf. James 2003a: 110), he has to stick to the masochistic game of desire he has been playing. Fulfilment is, however, as argued above, impossible. Consequently, when the editor actually tries to penetrate the 'closet,' and enters Juliana's room, perfectly aware of the necessity of heteronormative policing ("I wanted to give Miss Tita a chance to come to me" [James 2003a: 115]), his contradictory emotions reach their climax: "I was now, perhaps alone, unmolested, at the hour of temptation and secrecy, nearer to the tormenting treasure than I had ever been." (James 2003a: 116) Just when he is about to open the secretary, however, he faces Juliana's ghostly figure: "[She] stood there in her night-dress, in the doorway of her room, watching me; her hands were raised, she had lifted the everlasting curtain that covered half her face, and for the first, the last, the only time I beheld her extraordinary eyes. They glared at me, they made me horribly ashamed." (James 2003a: 117)

This shaming gaze reminds the editor of the impossibility of an unmeditated encounter with his object of homoerotic desire. He fails to acknowledge that this fantasy is only liveable if triangulated according to the rules of heteronormativity, 
and that is what the Borderaus keep offering him. As we shall see, however, even the enabling, liminal space of the house's garden cannot make the editor embrace this option.

\section{A Domestic Heterotopia: The Garden}

The Borderaus' garden, in which a great deal of the action takes place, functions importantly as a liminal space that enables readings of the characters' actions that go beyond their socially restricted interactions within the domestic space of the house. The garden carries a somewhat mystical air - meetings in the garden mostly take place at night or in the evening - and the narrative foregrounds its paradoxical qualities. When Juliana asks the editor why he does not prefer gardens on the main land to theirs, he answers: "Oh, it's the combination! [...] It's the idea of a garden in the middle of the sea." (James 2003a: 66) The in-between position of the garden, between nature and culture, inside and outside, gets combined with the contradictory characteristics of Venice - that it belongs neither fully to the land nor to the sea. The garden as a heterotopian space enables the tale's characters to deviate from their usual behaviour. Tita, who is rather shy inside the house, experiences emotional upheavals in the garden; and, more importantly, the editor, who usually tries to emphasise his masculinity, gets assigned feminising traits. He mentions his fanciful - and 'unmanly' - delight in flowers several times: "It's absurd if you like, for a man, but I can't live without flowers. [...] I live on flowers!" (James 2003a: 62; 64) Indeed, just as Mrs Prest criticises him for fighting his battle in the feminine space of a salon, the editor himself feminises his kind of 'warfare' by associating it with a decadent overflow of flowers: "[B]y flowers I would make my way - I would succeed by big nosegays. I would batter the old women with lilies - I would bombard their citadel with roses." (James 2003a: 77) Simultaneously, however, his explicit wish to have a garden ("I must have a garden - upon my honour I must!" [James 2003a: 61]) - ostensibly only used as a pretext to get into the house - makes the reader aware of the potentially enabling qualitites the garden can provide for the editor. His association with flowers is, in fact, what ultimately wins him the heterosocial confidence of his 'landladies:' "I think it was the flowers that won my suit." (James 2003a: 63)

The garden's contradictory qualities can help us establish a reading of the editor's conflicted desire, suspended between a wish for a heteronormative existence, associated with a stable, powerful notion of masculinity, and his homoerotic desire, associated with effeminacy, and a lack of 'proper' masculinity. The garden makes its first appearance when the editor is still outside the house, and sees "a high blank wall which appeared to confine an expanse of ground on one side of the 
house. [...A] few thin trees, with the poles of certain rickety trellises, were visible over the top." (James 2003a: 57) It is an enclosed garden, a "tangled enclosure" (James 2003a: 61), strongly reminiscient of the traditional symbolics of the 'hortus conclusus.' Considering that the 'hortus conclusus' is usually - especially in a biblical context - associated with the female, and female virginity in particular, and that the editor's aim is to get into the house, and get at its deepest secrets - Aspern's letters - it is not far-fetched to say that the editor, his first idea of how to reach his goal being to use the garden as a "pretext" (James 2003a: 58), and assuming a strongly masculine position for himself, attempts to penetrate the house, and rob it of its virginity. This assumption is also reflected in his explicitly planning " $[\mathrm{t}] \mathrm{o}$ make love to the niece" (James 2003a: 60), and enforced by the editor's thoughts in connection with the garden: "I must work the garden - I must work the garden" (James 2003a: 60), he reminds himself, as if the idea were rooted in a deeper desire than simply to use the garden as a pretext to get to some ulterior aim. The sexual connotation gets further strengthened by phrases such as the editor's "private ejaculation" (James 2003a: 61) at the thought of working the garden - the expression 'working the garden' itself bearing clear sexual implications. In the end, of course, this heterosexual reading of the editor's relation to both the house's garden, and it's female inhabitant turns out to be impossible, not least of all because the editor himself ultimately rejects it, and his striving for hyper-masculine, heterosexual virility within a heteronormative matrix remains a fantasy.

The editor's obsession with the garden has, in fact, from the start, a 'queer' side to it. Although the garden is repeatedly characterised as 'feminine,' and the house's mistresses are female, the editor, as demonstrated above, associates the house with different traits of masculinity, and identifies it with Jeffrey Aspern. Consequently, from his own point of view, the editor tries to penetrate a masculine-identified entity. The garden being in the back of the house, its sexual function evokes the image of anal penetration. Ironically, the editor explicitly denies that he himself will "cultivate the soil" (James 2003a: 61) - the phrase occurring in the same sentence as the "private ejaculation," bringing to mind the image of planting his semen into the earth. In the end, however, it is, indeed, the editor himself who works and cultivates the garden, turning its untamed, virginal character into an artificial landscape.

The garden is juxtaposed with the inside of the house in that, in the latter, the editor often feels insecure and patronised by his female 'companions,' whereas, in the garden, he seems to be more in control of his own thoughts and actions. It is, hence, not surprising that he "made a point of spending as much time as possible in the garden" (James 2003a: 76), in the space that liberates him, but that also makes the house seem even more like "an inscrutable old palace" (James 2003a: 77). The garden is the space in which the editor and Tita have their most private conversa- 
tions, where they are, to a degree, free from her aunt's controlling influence. It enables both Tita's fantasy of heterosexual union with the editor, and his own fantasy of heterosocial confidence, and ultimate homoerotic fulfilment through possession of the letters. In an almost comic encounter between the two, James makes the reader painfully aware of the editor's being oblivious, almost until the very end, of Tita's heterosexual reading of their meeting. He even explicitly disavows it, contrasting it with the heterosexual desire between Aspern and Juliana ("Miss Tita was not a poet's mistress any more than I was a poet." [James 2003a: 81]), and he blatantly misreads all of Tita's approaches: "She came out of the arbour almost as if she were going to throw herself into my arms. I hasten to add that she did nothing of the kind. [...] It was almost as if she were waiting for something - something I might say to her - and intended to give me my opportunity." (James 2003a: 81; 83)

Caught up in the rhetoric of his 'closeted' existence, and the paranoid, homoerotic/heterosocial readings he applies to everything, the editor simply lacks the parameters to understand Tita's 'physical rhetoric' in heterosexual terms. It is clear that the conflict between Tita's heterosexual, and the editor's heterosocial rhetoric, neither of which can be made explicit by either of them, cannot be resolved, and ends only in an acknowledgement of confusion on Tita's part: "'Why don't you believe me?' 'Because I don't understand you.'” (James 2003a: 86) The editor's disavowal of acknowledging Tita's heterosexual understanding of the situation is far more conscious: "I had no wish to have it on my conscience that I might pass for having made love to her." (James 2003a: 86)

While the garden cannot enable the editor to make his homoerotic desire explicit, the encounters in this space make him actively reject the heterosexual triangulation of his wish to get at the Aspern Papers, which, in the beginning, he still claimed to be an option. He can conceive of Tita as a means to get at what he really desires, but only within the temporally limited framework of his stay in Venice. He is willing to make use of this 'traffic in women' as long as it is not institutionalised in striktly heteronormative terms: "I could not linger there to act as guardian to a piece of middle-aged female helplessness. If she had not saved the papers wherein should I be indebted to her?" (James 2003a: 121) The house's garden is the space in which the editor is able to enact this temporally limited, suspended heterosocial bond, whereas the domestic space of the house (associated with, and embodied by Tita and Juliana) would have him enact 'the real thing,' and marry Tita. This kind of heterosexual commitment is, however, exactly what the editor rejects, which is reflected spatially in his preference to meet Tita outside the domestic space of heterosexual intimacy: "Somehow I preferred not to be shut up with her; gardens and big halls seemed better places to talk." (James 2003a: 121) After Juliana's death, the editor feels her influence fade, and the in-between, non-normative qualities of the garden (and the sea) take over the house: he feels "a freshness from the sea 
which stirred the flowers in the garden and made a pleasant draught in the house, less shuttered and dark now than when the old woman was alive" (James 2003a: 121).

The garden, then, can be read in two ways. Firstly, it is a symbol of the editor's obsession with emphasising his own masculine ability - which is constantly being questioned - penetrating the traditionally feminine-identified 'hortus conclusus,' and the virginity of the house, its owners, and their secrets - in which he fails: Juliana, the supposed keeper of the secret, is repeatedly described as "impenetrable" (e.g. James 2003a: 66), and the palace as "inscrutable" (e.g. James 2003a: 77). Secondly, the garden is a sign of the editor's homoerotic desire for Jeffrey Aspern, who is constantly identified with the house. This configuration is, again, an example of the triangulation of the editor's homoerotic longing for Aspern. The editor desires the dead poet, and this homoerotic fantasy gets disguised by redirecting it via a third, female part, in this case the female connotations of the 'hortus conclusus' and Tita. The editor will, however, ultimately reject any kind of heteronormative triangulation, failing to see that it would be the only way he can get what he wants - Aspern's letters, and a (mediated) reunion with his object of homoerotic longing.

\section{A Liminal City: Venice}

It is significant that James sets his tale in the city of Venice, a place that "has always attracted the cultural imagination" (O`Neill et al. 2012: 2), and which, as mentioned above, due to its geographical position between land and sea, adds another dimension of heterotopian spatiality to the story. "In eighteenth and nineteenth-century literature, Venice is often praised for its exotic qualities of death and decay" (Fujikawa 2008: 104), easily lending itself as a spatial metaphor of temporal liminality. Michael O’Neill, Mark Sandy, and Sarah Wootton also note that " $[t]$ he city's hold over many writers and artists from Europe and America is bound up with [...] doubleness. [...They] have sensed in the city a range of imaginatively productive dualities." (O`Neill et al. 2012: 2) Venice, as James, too, constructs it in "The Aspern Papers," is a space that contains various contradictory notions: he establishes it as a place where the past and the present, the inner and the outer, the private and the public get mixed up, and seem to exist simultaneously. It also becomes a space in which the lines between the homosocial and the homoerotic begin to blur, and in which the editor can experience an unusually close mental union with Aspern. For James, "Venice was something of a sexualised locale that had allowed him to admire beautiful young men and then convey that admiration in a somewhat cryptic manner" (Hoeveler 2008: 128) in his letters to J. A. Symonds, 
and he makes use of this experience of the city in his fiction. In "The Aspern Papers," Venice becomes the space that enables the editor's homoerotic fantasies.

The borders between the past and the present become fluid and permeable when the editor walks through the streets of the city, or imagines his being in it. In one of his imaginary conversations with Aspern, and referring to Juliana, he declares:

"Poor dear, be easy with her; she has some natural prejudices; only give her time. Strange as it may appear to you she was very attractive in 1820 . Meanwhile are we not in Venice together, and what better place is there for the meeting of dear friends? See how it glows with the advancing summer; how the sky and the sea and the rosy air and the marble of the palaces all shimmer and melt together." (James 2003a: 75)

In this short passage, time gets completely confused. Aspern, Juliana, and the editor all seem to come together in an ageless, timeless space, and, for the reader, it becomes unclear whether it is Aspern who has come back to the present, or the editor who has gone back to the past. Even Juliana, who is not even physically present in the 'conversation,' gets temporally displaced. Venice enables the editor to have this "eccentric private errand," to feel "a mystic companionship, a moral fraternity with all those who in the past had been in the service of art" (James 2003a: 75). Venice becomes the heterotopia in which the editor's desire to reach Aspern can be fulfilled as nearly as nowhere else. Here, his homoerotic passion does not have to be triangulated. On the contrary, in his imaginary union with Aspern, the editor can afford to patronisingly dismiss the 'poor dear' woman. This heterotopian fulfilment, of course, remains suspended as a product of the editor's fantasy. It does, however, bring him closer to his object of desire than any of his attempts within the female-dominated space of the Borderaus' house do.

Venice is both a place that enables the editor to try and realise his homoerotic desire, and a constant reference point for thoughts that express his wish to emphasise his own masculinity. Referring to Venice, the editor associates private spaces and the indoors with Tita and Juliana, while he is himself obsessed with moving in public spaces and the outdoors. He clings to a notion of gendered space that is reminiscent of an ideology of 'separate spheres,' juxtaposing a masculine public with a restriction of women to private spaces. The editor admits that he often feels the desire to leave the house to walk in the streets of Venice, or sit in front of San Marco, "listening to music, talking with acquaintances[...,] with all the lamps, all the voices and light footsteps on marble" (James 2003a: 80). The feeling of being in a public space comforts him, and strengthens his masculinity, although - unconsciously - he simultaneously contradicts his own desire in placing the outdoors 
inside again when he compares the piazza to "an open-air saloon" (James 2003a: 80). This paradoxical notion is repeated at the end of the story when the editor compares the city to "an immense collective apartment, in which Piazza San Marco is the most ornamented corner and palaces and churches, for the rest, play the part of great divans of repose, tables of entertainment, expanses of decoration." (James 2003a: 129)

The outside becomes the inside; the city gets domesticated and - with "ornamented corners" and "decoration" - clearly feminised. Although the editor thus finally gets to have the house he has been denied so far, he also confirms his own demasculinisation. In his simultaneous struggle against this demasculinisation, however, he also imagines the Borderau women as being restricted to their home - to their 'proper sphere' - when he thinks of "the Misses Borderau and of the pity of their being shut up in [their] apartments" (James 2003a: 129). It is striking that the editor uses the term "shut up," which implies that the act of staying at home is involuntary. As we learn in the course of the story, however, the two women's seclusion is a chosen one, at least for Juliana. Nevertheless, the editor mentally places them in a position of traditional femininity. Considering that in business - and in her whole attitude - Juliana clearly dominates the editor, and refuses to comply with the gender role he tries to impose on her, he has no choice but to imagine himself in a position in which he is actually not.

The construction of Venice as a liminal space becomes further apparent when the editor compares the city to a theatre, a stage on which socially prescribed roles are exposed as mere performances:

"And somehow the splendid common domicile, familiar, domestic and resonant, also resembles a theatre, with actors clicking over bridges and, in straggling processions, tripping along fondamentas. As you sit in your gondola the footways that in certain parts edge the canals assume to the eye the importance of a stage, meeting it at the same angle, and the Venetian figures, moving to and fro against the battered scenery of their little houses of comedy, strike you as members of an endless dramatic troupe." (James 2003a: 129)

At the end of the story, having failed to reach is goal - the papers, and the fulfilment of his utopian vision of a homoerotic union with Aspern - the editor's comparison of Venice with the theatre is his last attempt to save the city for himself as an enabling liminal space. Even the theatre, however, fails to provide fulfilment. Having left the Borderaus' house, and aimlessly wandering through the streets of Venice, he reaches the statue of Bartolomeo Colleoni, a famous Venetian 'condottiere,' a leader of mercenary soldiers in fourteenth- and fifteenth-century Italy, and the embodiment of combative masculine strength. Desperately looking for guid- 
ance, the editor finds himself "staring at the triumphant captain as if he had an oracle on his lips" (James 2003a: 129). Militant masculinity, however, cannot provide him with help: "[Bartolomeo] could not direct me what to do." (James 2003a: 129)

The outdoors of Venice is the space the editor instinctively turns to when his last attempt to get what he wants has failed, and he has been shamed by Juliana's heteronormative, policing gaze. After this last encounter with her, the editor immediately leaves the house and rushes, once again, into the Venetian liminal outdoors. He wants to go "[a]nywhere, anywhere; out into the lagoon!" (James 2003a: 127). It is here, in the space that has provided the backdrop for his imaginary union with Aspern, that he finally realises the impossibility of his conforming to a heteronormative triangulation of his desire: "What in the name of the preposterous did [Tita] mean if she did not mean to offer me her hand? That was the price - that was the price! And did she think I wanted it, poor deluded, infatuated, extravagant lady? [...] I could not pay the price. I could not accept." (James 2003a: 127) The editor cannot, of course, stay suspended in his aimless wanderings of the canals and piazzas of Venice forever. This real space, as liminal as it might be, cannot provide him with what he wants, and he ultimately has to go back to the house, and face the consequences of his rejection of a heteronormative existence.

\section{Homoerotic Desire Denied: The Ending}

The tale's ending leaves it open to speculation whether or not the Borderaus really had any of Aspern's letters, whether their 'closet' rhetoric actually concealed a real secret, or whether they just took advantage of the editor's paranoid need to read it as such. Clearly, Tita increasingly emphasises that the only way for the editor to get at the fetishised documents, the objects of his impossible homoerotic desire, is through a heterosexual union with her: "[I]f you were a relation it would be different. [...] Anything that is mine - would be yours." (James 2003a: 125) The editor, however, cannot frame his fantasy in heternormative terms, and his gaze remains fixed on "Jeffrey Aspern's face in the little picture [his portrait], partly in order not to look at that of my interlocutress, which had begun to trouble me, even to frighten me a little." (James 2003a: 124) His wish to penetrate the women's 'closet' heterosocially - in becoming their secret sharer - and achieve a state of unpoliced, homoerotic satisfaction, is disappointed. He fails to see what the tale's premise predicts from the very start: his desire cannot be fulfilled, the poet is dead, and the rules of heteronormativity must be adhered to. To an extent, the editor acknowledges this through his inability to name the reason for his not wanting to marry Tita. His explanation remains void, unspoken, an 'open secret:' "I stood there dumb. [...] 'Ah, Miss Tita - ah, Miss Tita,' I stammered, for all reply. [...] 'It 
wouldn't do - it wouldn't do!" (James 2003a: 126; 27) The editor's “continuing problems with composing" (Church 1990: 35), his frequent inability to speak, "the sometimes quite elaborate blockages of self-expression" (Mengham 1997: 44) that several critics have commented on mark him - and, in extension, his desire - as unnameable. They reinforce the rhetorical association of his secret with the homosexual 'closet,' and emphasise that the phallic power over language remains in the hands of the tale's surviving woman.

In the end, the editor is defeated. Miss Tita consciously replaces her aunt in a position of spatial power within her house, "receiv[ing] him in her aunt's forlorn parlour. [...] She stood in the middle of the room with a face of mildness bent upon me." (James 2003a: 130) Her posture and self-confidence awe the editor into accepting the rules of heteronormativity: "It seemed to me I was ready to pay the price." (James 2003a: 130) It is, however, too late. Tita denies the editor another chance, the triangle is broken, and she eliminates the 'closet' that has held so much allure for him: "I have done the great thing. I have destroyed the papers." (James 2003a: 131) It remains open whether she has actually destroyed them (and whether or not there was something to destroy in the first place), or whether she merely acknowledges implicitly that her desired triangulated union with the editor will not take place. It has, in any case, been clear from the beginning that the editor can never actually get to touch the papers. His desire can only exist under the condition that it remain unfulfilled, suspended, and triangulated. "By trying to break through this border and extract the papers from Juliana's caress, the narrator sentences the papers to ash." (Rosenberg 2008: 209) Whether the letters 'really' existed or not, the effect is the same: the editor is left staring melancholically at Aspern's portrait. "When I look at it my chagrin at the loss of the letters becomes almost intolerable." (James 2003a: 131) He has failed to see in time that, despite his moments of imaginary triumph and eroticised enjoyment in the temporally enabling spaces of Venice and the garden, he could never penetrate the Borderaus' female domestic 'closet' that held the key to his own mental 'closet.' Always the paranoid 'closet' reader, the only option the world of this tale would give him - to triangulate his desire in heteronormative terms - is first invisible, and then impossible for him. Trapped between the impulse to establish a stable, 'masculine' gender identity for himself, and the wish to live his homoerotic desire, he rejects a heteronormative choice, and has to face the impossibility of any real fulfilment of his homoerotic fantasy.

For the 1908 New York edition of "The Aspern Papers," James re-phrased the tale's last sentence: "When I look at it [Aspern's portrait], I can scarcely bear my loss - I mean of the precious papers." (qtd. in Brown 1991: 268) Through the introduction of the dash in the latter version, it becomes even more obvious that the loss is something more than the mere loss of Aspern's letters. The editor "experiences 
a more ambiguous, unnameable loss and suffers because of it" (Brown 1991: 269). The very unnameability of his suffering moves it into the vicinity of the 'closet,' and makes it recognisable only to the 'paranoid reader' who will understand the editor's desire as homoerotic, a desire that cannot be spoken, but that must be continually alluded to. 'It takes one to know one.'

\section{Female Power in the Cage of Knowledge: Henry James' "In the Cage"}

"In the Cage," first published in 1898 , is, on the surface, primarily a story about class. A nameless young female telegraphist, who has barely escaped extreme poverty, leads a respectable, but mediocre existence 'in the cage' of a small telegraph office in London, fantasising about the lives of the rich, upper-class people she serves. While, however, her situation is mainly represented as one of female powerlessness and spatial confinement, she manages, in the course of the story, to turn her fantasies of power into actual influence over one of her male customers, and questions of gender - particularly the blackmailability of paranoid masculinity in "a culture in which social relations are maintained through the exchange of signs, rather than through face-to-face encounters" (Keep 2011: 251) - and the distribution of power over knowledge become the story's main driving forces. This power is based on the dynamics of a discourse of secrecy that relies mostly on the simultaneously interpellating and enabling nature of language itself: "What James stages in this story is the indirect power, the oblique possession [...] that is afforded by the enabling constraints that constitute our social life - by the canny cage of communicative codes." (Buelens 2006: 129)

James sets this rhetoric of power in fictional spaces that serve to enable multiple meanings and associations that go beyond the mere signifiers of language. His use of space in this tale is a prime example of his awareness of its metaphorical potential concerning not only class, but also gendered power relations. While starting out stuck in her 'cage,' the telegraphist soon both dares to extend the space of her actions to the - increasingly liminal - outdoors (the city, the park, the seaside), and starts to regard her position 'in the cage,' at the centre of the transfer of knowledge, as desirable. Although the tale's ending sees its protagonist disillusioned, and accepting her safe, but relatively powerless and unexciting existence, James, nevertheless, lets her have her moment of triumph, and ultimately depicts his male characters as less cunning, less imaginative, and less able to exercise power over others than his women.

"James is fascinated with the epistemology of the secret that will not reveal itself” (Stevens 1998: 122), as Hugh Stevens observes; particularly, I would add, with a secret that is gendered masculine. Stevens goes on to identify, at the centre 
of James' rhetoric, ways in which "secrecy and ambiguity intersect with a discursive regime of power, knowledge and public representation" (Stevens 1998: 122). In "In the Cage," secretive masculinity is perceived as both desirable - in that it affords those (women) who try to penetrate its secrets a feeling of power and excitement - and exposed to the self-destructive mechanisms of paranoia. The rhetoric James employs is that of the knowledge of a scandal; and although this scandal revolves around issues of illicit heterosexual behaviour (an affair between Captain Everard and the married Lady Bradeen), James unmistakably employs the language of the 'closet' and the open secret of homosexuality, which, by the end of the nineteenth century, had become a major public concern in England. Eric Savoy's detailed analysis of the tale demonstrates a reading of the text as having at its centre a "fundamental queerness, which arises from James' displacement of fin-de-siècle homosexual panic into the narrative economies of heterosexual transgression. [...L]ike the gay closet, it is the site of panic that acquires specificity only when it is threatened by imminent disclosure and disruption." (Savoy 1995: 287; 296)

While I agree with the text's potential for a queer reading, I argue that James' intuitive grasp on the historicity of modern homosexuality as embedded in more general discourses of paranoid masculine self-definition goes even further. I will suggest a reading that sees James' re-fashioning of the 'closet' in primarily heteronormative terms not as an evasion, but as a powerful rhetorical move that shows the mechanisms of the queer 'closet' both to be inextricably linked with contemporary discourses on deviant (male) sexuality, and to work independently from those modern definitions. In "In the Cage," hence, James demonstrates not only that the 'queer closet' is not necessarily 'homosexual,' (in that, as Eve Sedgwick demonstrates, 'homosexual panic' affects both closeted 'homosexuals' and 'heterosexual' men), but also that its rhetoric builds on a spatiality of binaries (private/ public, feminine/masculine), densely semanticised with an epistemological logic of power, that goes back to the very beginning of 'modernity.' The masculine 'closet' has always been there, and, moreover, it has always been 'queer', in that it has continuously questioned a stable, heteronormative, patriarchal masculine identity. Secrecy enables queer performativity by creating a void that the paranoid reader can fill: "Queer performativity, then, does not oppose an already constituted individual subject to the social world, but locates ontologically charged moments when subjectivity is formed through negotiation with social stigmas, with the taboo." (Stevens 1998: 123) Modern discourses on binary sexual identities only add another dimension to the paranoid readability of the masculine 'closet,' and make it - if possible - even more paranoid. Through his use of language, James positions the queer 'closet' at the very centre of social interaction: 
"[Q]ueerness is inscribed not simply in his characters but in their everyday lives, in the way they talk to each other, and in the way James writes about them. [...T] Jame Jamian style effect brings deviance to the fore by showing it not to be 'hidden' beneath exteriors but to be always in operation alongside conformity, as a sort of rhetorical effect or aesthetic value that, in its excess, is detached and turned against conformity." (Laughlin 2010: 155)

Just as James' queer rhetoric eludes any definite reading as 'sexual,' his construction of fictional spatiality emphasises less the definite meaning of space than the degree of possibilities that certain spaces afford the characters that move in them on various axes of binary oppositions - private/public, feminine/masculine, central/liminal - which, however, never become explicit. These binary oppositions, at the same time, become questioned and permeable, and the telegraph is the symbol of this effect: "The telegraph responds to a world in which the old boundaries between public and private, the industrial economy and household economics, 'society' in the sense of the nation and 'Society' in the sense of culture, have broken down." (Rowe 2000: 87) In this changing spatiality, the private becomes public, and secrets become readable through signifiers in public circulation.

\section{Confinement in the Cage of Knowledge}

The tale's opening paragraphs present the telegraphist's ambiguous spatial situation: although she spends, "in framed and wired confinement, the life of a guinea-pig or a magpie," it is not at all clear whether the "transparent screen [behind which she works] fenced out or fenced in" (James 2003b: 229). While her life 'in the cage' suggests an "effect of inscribing the female telegraphist within the regime of the visible, and in doing so exposing her to [the] controlling gaze" (Keep 2011: 249) of the institution she serves, the narrator also hints at the epistemological possibilities accessible only to those within the cage of telegraphic communication, to the exclusion of those on the other side. Although the space of the little telegraph office is repeatedly characterised as prison-like and restricting (cf. Olson 2009: 244-245), and the telegraphist experiences its self-defined middle-class respectability as constantly intruded on by its being part of a (supposedly socially inferior, though actually equally lower-middle-class) grocery store, the employees of this little office are in charge of handling information, a privilege that those 'outside' are dependent on. From the start, the protagonist is aware of this potentially advantageous position: "It had occurred to her early that in her position [...] she should know a great many persons without their recognising the acquaintance." (James 2003b: 229) The telegraphist is the objectified embodiment of a modern 
mechanism that people employ for the exchange of information, "reduced [...] to a means to an end" (Olson 2009: 245). She is, however, aware that, because this position, in theory, asks of her to have no opinion of her own on the information she handles, it will potentially make people 'confide' in the system, and in her. Historically, "[t]he telegraphic cage is an obvious example of a public space in which private knowledge became commodified" (Savoy 1995: 292). This blurring of the boundaries between public and private information was, naturally, perceived as a potential danger: "The development of the telegram posed a new potential for blackmail, or at least for a loss of control of information." (Moody 1995: 59) The possible mishandling of private information in the hands of a female telegraphist in particular is a theme contemporary readers would have picked up on, since, as Christopher Keep shows, it was widely assumed that, "too likely to be swayed by her need for romance, or to fall under the spell of those who might profit from access to the sensitive information to which she had such ready access, the female telegraphist was seen as a danger to the security of the nation's communications" (Keep 2011: 248). The conflict is obviously gendered, for, as Keep goes on to say, "it is not simply the technologies for the transmission and receipt of knowledge that are at risk, but the women who are employed in the service of these technologies" (Keep 2011: 251). The employment of women as telegraphists puts them at the very centre of the transfer of private information.

The protagonist's awareness of her potentially advantageous position is made even more explicit after her first encounter with Captain Everard, the gentleman who will later become her obsession. She is conscious of "the double life that, in the cage, she grew at last to lead," that of "public servant and private reader" (Savoy 1995: 285), of 'neutral passer-on of information' and paranoid reader, who will look for meaning in any of her customers" "whiffs and glimpses" (James 2003b: 239). The young woman's 'readings' of her upper-class customers through their telegraphic communications is crucially influenced by her consummation of "novels, very greasy, in fine print and all about fine folks" (James 2003b: 231), providing her with an interpretative framework that makes her see the world through the lens of fictional romance that stands in stark contrast to the 'real' world:

"[S]he reads the telegraphs [...] through the very paradigms she is familiar with from her trashy romances. (Nixon 1999: 190) What James constructs, then, is literally and metaphorically a reading gaol - a socially imposed cage, in which the female subject [...] conflates life and art, only to find that her prison has a pragmatic dimension that resists being co-opted into a form of romance." (Nixon 1999: 182) 
While it is true that James criticises his heroine's socially conditioned naiveté, and makes her live through a process of growing awareness (and ultimate acceptance) of the harsh realities of her lower-middle-class existence, I would like to draw attention to the subversive dimension of this 'female reader.' The reference to novel reading serves both as a critique of a life-as-fantasy attitude, and as a reference to the actual power of the reader: although James makes explicit that his protagonist's 'reading technique' is mainly directed by her imagination, he, at the same time, leaves open the possibility of actual knowledge and power. He acknowledges (albeit ironically) that the telegraphist's "eye for types amounted [...] to genius" (James 2003b: 239), and that, more importantly, she experiences an actual feeling of power:

"[S]he had, at moments, in private, a triumphant, vicious feeling of mastery and power, a sense of having their silly, guilty secrets in her pocket, her small retentive brain, and thereby knowing so much more about them than they suspected or would care to think. There were those she would like to betray, to trip up, to bring down with words altered and fatal." (James 2003b: 240)

This paragraph conveys much of what James' narrative does repeatedly throughout the tale: while always, with an ironic wink, questioning the actual power his heroine can have over her customers, sentences like these generate a sense of paranoia that is due to the way issues of privacy and the important, identity-establishing functions of secrecy are ingrained in modern Western culture - and reflected in its literary tradition. By both making the telegraphist female, and having her spy on the secrets of the upper classes, James playfully touches on fundamental anxieties of modern patriarchal English culture: the loss of clear-cut class boundaries, and of a male monopoly on knowledge management. The paranoia, however, is twofold: the telegraphist, blindly believing in her own powers of intuition, becomes a paranoid reader, looking for meaning where none might be (or a different kind), triggering actual psychological paranoia in the people she 'reads.' To a patriarchal culture in which masculinity is constructed as inherently paranoid, women who read are dangerous indeed. The narrator acknowledges this by commenting that "[h]er conceit, her baffled vanity were possibly monstrous" (James 2003b: 240). In this dynamic, it is not a contradiction that the protagonist admits to spying mainly on the ladies at first. In James' fictional world, the women are the ones pulling the strings, both concerning the amount of information that is being circulated, and in their relation to the other sex: "[I]t was literally visible that the general attitude of the one sex [the men] was that of the object pursued and defensive, apologetic and attenuating." (James 2003b: 241) That the knowledge that is so often hinted at, but never named, while never becoming explicitly sexual knowledge, provokes 
sexual associations is not least due to the telling names of the office and its most prominent male customer: Cocker's and Captain Ever[h]ard evoke a phallic symbolism that draws attention to the very masculine virility that this tale negotiates and questions (cf. Stevens 1998: 127).

The dynamics established so far will become more obvious when looking at the tale's three main relationships: between the protagonist and her friend and rival Mrs Jordan; between the protagonist and her fiancé Mr Mudge; and between the protagonist and Captain Everard. It will become clear that it is within the homosocial dynamics of the relationships between the women that power is negotiated, and knowledge acquired and used. The men are reduced to the third part of the triangle in which this power traffic takes place. In all this, however, James insists on a strong ironic undercurrent that never lets the conflict become too obvious. In the end, his heroine is not triumphant in seriously questioning established power relations; his narrative's rhetoric, however, is.

\section{Female Rivalry over Knowledge in Space: The Telegraphist and Mrs Jordan}

While most critics focus their readings of James' tale entirely on the relationship between the telegraphist and Captain Everard, I would like to show that the protagonist's interactions with both her friend Mrs Jordan and her fiancé Mr Mudge crucially supplement the main plot's homo- and heterosocial dynamics, especially concerning the metaphorical qualities of space.

The relationship between the protagonist and Mrs Jordan can best be described as a homosocial rivalry between equals over who has got more power through knowledge. Both of them lower-middle-class from some undefined, more 'genteel' background, they have worked themselves out of poverty, and both find themselves (or believe to find themselves) in spatial situations that are advantageous for acquiring knowledge about - and hence power over - those to whose class the two of them can never belong. Both women, by trying to outdo each other in arguing for their own spatially more attractive position, become subversive figures, using their socially accepted positions of access to knowledge for their own struggle to make themselves look more powerful in the eyes of the other.

While the telegraphist's access to knowledge relies very much on the modern space of virtualised communication of her office, and her public and exposed situation there, Mrs Jordan occupies a more traditional position, which is more directly related to modern anxieties over domestic privacy as it is also reflected in Gothic and sensation fiction: she "had invented a new career for women - that of being in and out of people's houses to look after the flowers" (James 2003b: 231). Within the space of only a few sentences, James constructs "the way [Mrs Jordan] 
was made free of the greatest houses" such that not only has she access to "all the rooms," but also, by bringing the outdoors (the flowers) indoors, creates "a sort of tropical solitude" (James 2003b: 231), a liminal space, "like a new Eden" (James 2003b: 242), that allows her to imagine "that a single step more would socially, would absolutely, introduce her" (James 2003b: 231). Mrs Jordan's arranging the flowers borders, in this rhetoric, on an imaginary subversion of established class boundaries, represented in domestic space. Any actual power and influence remain, of course, her fantasy: "[H]er imaginative life was the life in which she spent most of her time." (James 2003b: 232) James' repeated association of flowers with the upper classes, in fact, emphasises Mrs Jordan's not belonging to that class (since the flowers are not hers), and her delusion comes across as slightly pathetic. As before, however, James' benevolent mockery of his characters does not fully obscure the real potential for unease that he creates in this account of subverted domesticity: "[S]he more than peeped in - she penetrated. There was not a house of the great kind [...] in which she was not [...] all over the place." (James 2003b: 243) Mrs Jordan's position constantly alludes to the real possibility of secrets unveiled, and barriers of class (and possibly gender) torn down.

This becomes especially obvious when the protagonist, while being repeatedly awed by Mrs Jordan's access to the domestic spaces of the upper ranks of society, and acknowledging that "she could never [...] have found her way about one of the "homes"" (James 2003b: 243), explicitly tries to convince herself that her own influence over people is more real, more powerful: "Combinations of flowers and green-stuff, forsooth! What she could handle freely, she said to herself, was combinations of men and women." (James 2003b: 232) Mrs Jordan, however, is equally convinced that she makes the inhabitants of 'her' houses "feel they could trust her without a tremor" (James 2003b: 242). It is, in fact, the combination of both women's spatial situation that conveys to the reader a sense of actual social unease. Both, in their own way, evoke an imagery of both female spatial confinement (the domestic, the 'cage') and female spatial subversion (domestic access in one case, the woman in public in the other), two powerful themes from the Gothic tradition. Not only do both women have the potential to unveil Bluebeard's secret, it is their profession that puts them where they are. It is their job to pry and know. The people they 'know' something about become reduced to mere objects in the women's rhetoric of competitive power: "I dare say it's some of your people that $I$ do.' [...] 'I doubt if you 'do' them as much as I! Their affairs, their appointments and arrangements, their little games and secrets and vices - those things all pass before me. [...] I find out everything."' (James 2003b: 246)

It is not only, however, those of higher social rank that the two women are competing to 'know' better, but also each other, and their little secrets. In this context, James, again, playfully acknowledges the performative nature of a rhetoric 
of knowledge as power. When the telegraphist asks her friend: "But does one personally know them?" (James 2003b: 244), meaning the people the latter does the flowers for, she both questions Mrs Jordan's real influence over those people, and, at the same time, makes clear that she 'knows' the way 'one' is supposed to speak when 'one' wants to be influential at all in those higher social spheres. Similarly, on an occasion on which Mrs Jordan asks the protagonist to send a telegram to the former's employer, both are equally convinced of their knowing more than the other: Mrs Jordan, aware that her message, containing "an unintelligible enumeration of numbers, colours, days, hours" (James 2003b: 245), is incomprehensible to the telegraphist, consciously takes pride in the 'secrets' of her business, and performs an act of exaggerated over-significance in just saying: "I do flowers, you know." (James 2003b: 245) The telegraphist, however, is equally aware that the mere fact of Mrs Jordan's having to rely on her to communicate 'important' information constitutes a "small secret advantage, a sharpness of triumph" (James 2003b: 245). The effect of this is, of course, emphatically comic: the reader is conscious that neither Mrs Jordan nor the telegraphist are actually handling information of any significance whatsoever. This very comic effect, however, draws attention to the ways in which a rhetoric of knowledge alone ('You know I know something.') has a powerful impact.

The competitive dynamics between the two women culminate in the tale's finale scene, in which the important underlying themes of their relationship again surface and combine. In their continued rhetoric of excessive hinting and deliberate vagueness, images of domesticity become the means to juxtapose the two women's fantastic, class-climbing aspirations with a life of lower-middle-class mediocrity. Not only is Mrs Jordan's home explicitly contrasted with the fantastic nature and heterotopian potential of her employer's houses by there explicitly being "no sign of a flower" (James 2003b: 293), but both women finally admit to the desirability of the more realistic goal of a comfortable home of their own by marrying 'attainable' men: the telegraphist reminds herself that "[w]e shall have our own house," and Mrs Jordan replies that "[w]e shall have our own too" (James 2003b: 298). An ideal of 'safe,' middle-class domesticity - and, hence, normative femininity - is contrasted with the domestic space of higher classes that the two women will never actually penetrate socially.

At the same time, the 'knowledge' that has so far only been vaguely referred to now becomes explicit, to a significant and, again, comic effect. While the two women's 'knowledge' of their upper-class employers and customers amounts to nothing that actually affords the former any significant influence over the latter and, indeed, the telegraphist must admit to herself that, in fact, she did not really 'know' anything at all - the rhetorically prolonged, and elaborately playful act of exposure that Mrs Jordan performs, proving that, after all, she 'knows' more than 
her friend, does effect a feeling of triumph on her part: "Don't you know, dear, that [Captain Everard] has nothing? [...] Why, don't you know?" (James 2003b: 299; 300) This feeling, however, is checked by her simultaneously having to expose both the "loved friend" (James 2003b: 293) she gets her information from as her future husband, and this future husband as being 'merely' the butler of one of 'her' great families, triggering, in turn, a feeling of triumph in the telegraphist, for "[i]t was better surely not to learn things at all than to learn them by the butler" (James 2003b: 296).

James manages to stage this linguistic battle over knowledge such that, in the end, it becomes almost insignificant what is actually exposed; if, that is, it were not for another effect: by revealing Mrs Jordan's future husband to be a butler, and, more significantly, by exposing the tale's alleged male 'hero' to be not only penniless, but also not master of his new home ("How can he, with any authority, when nothing in the house is his?" [James 2003b: 299]), involved in a scandal that was "on the very point of coming out" (James 2003b: 300), and being "in something" (James 2003b: 301), James, playing on the rhetoric of the 'closet,' and despite satirising his lower-middle-class protagonist's fight over power as fantastic, reduces the men in this tale to objects to be traded in his female characters' interest: to be married either - in the case of the telegraphist and Mrs Jordan - to secure a stable, albeit mediocre, middle-class existence, or - in the case of Lady Bradeen - to get the man she wants, and make him financially dependent on her.

\section{Spatial Respectability: The Telegraphist and Mr Mudge}

One of the tale's two important male characters is the telegraphist's fiancé $\mathrm{Mr}$ Mudge, whose name's "telling mixture of 'mud' and 'drudge' [...] reminds the reader of the foodstuffs he works with and the material nature of trade in general" (Olson 2009: 246). James creates him as an extreme example of mediocre, working-/aspiring-lower-middle-class respectability. While he is obsessed with, and represents, from a spatial point of view, the normative, capitalist, masculine indoors of the workplace, the subplot depicting his relationship with the protagonist also enables her to temporarily move out of this stifling sphere into the liminal space of a seaside resort that, for a while, liberates and enables her to both reflect on her life and relationships, and to break free from the social conventions that normally keep her from being honest with herself and others.

Mr Mudge is introduced as a man obsessed with space, and with his ability to have spatial access to, and control over his future wife. Having been removed to a job in "a higher sphere" himself, he expects the telegraphist to follow him there, and to work "under the very roof where he was foreman," and where "he 
should see her, as he called it, "hourly"' (James 2003b: 230). The young woman perceives this masculine access to her body as uncomfortable, and she is determined not to give up her current relative liberty too soon, being aware of "the improvement of not having to take her present and her future at once" (James 2003b: 230). The narrative repeatedly refers to the telegraphist as "the betrothed of Mr. Mudge" (James 2003b: 244; 247; 248 [twice]; 272 [as "his betrothed"]; 273 [as "his betrothed"]), both drawing attention to his 'owning' her, and, at the same time, through over-emphasis, making the reader aware of her reluctance to comfortably occupy this position as object of a male capitalist desire for ownership.

Notably, although Mr Mudge is clearly associated with the indoors of the lower-middle-class, capitalist workplace that he dedicates his whole life to, most actual encounters between himself and the telegraphist are set in the outdoors and the public, "in the Regent's Park," or "in the Strand" (James 2003b: 248). Her determination to emphasise their fundamental difference ("She was not different only at one point, she was different all round." [James 2003b: 248]) - his being fundamentally working-class versus her being fundamentally a "lady manquée" (Galvan 2001: 299) - is reflected in her meeting him only outside the spaces that he moves in, and that, for her, represent finality and powerlessness. She explicitly contrasts these spaces with those she herself occupies professionally, and which she believes to afford her some power: "Where I am I still see things." (James 2003b: 250) She tries to explain to Mr Mudge why she derives pleasure from her position 'in the cage:' "What I 'like' is just to loathe them [her customers]. [...] It's immense fun." (James 2003b: 251) Mr Mudge, however, is too much a man of "propriety" (James 2003b: 251) to appreciate this kind of half-masochistic, class- and gender-conscious pleasure. His character sharply contrasts with the telegraphist's curious, subversive drives. She sees the potential power of knowledge acquired, and the desire to occupy a position that affords her to do so is her way of expressing the wish to break free from her life as governed by normative rules of class and gender. She is willing to explore the potential of her constrained spatial situation, deriving "a rush of interpretative pleasure" from her position as reader of other people's lives, "suggesting an erotic connection between enclosure and interpretation" (Olson 2009: 247) that is evocative of the female Gothic of the kind of Radcliffe's Udolpho.

Mr Mudge, on the other hand, is "troubled by the suspicion of subtleties on his companion's part that spoiled the straight view" (James 2003b: 252). He fails to see that the straight view is exactly what the young woman refuses to live by. She wants to penetrate the secrets of those who are her social superiors (men, and the upper classes), because she enjoys the feeling of power over those that are normally out of her reach. Mr Mudge is not only 'just' a man of her own class (and as such an impossible object of her eroticised subversive fantasies), but his lack of 'subtleties,' 
the fact that he holds no secrets for his fiancé, also makes him, to her, an admittedly 'safe,' but also extremely uninteresting man. What fascinates the young woman in Captain Everard, as we shall see later, is not just his obviously higher social standing, but also, and not least of all, the fact that she does not 'know' everything about him, that she needs to figure him out. The young woman idealises paranoid masculinity as a source of pleasure, an attitude that Mr Mudge, "habitually inclined to the scrutiny of all mysteries" (James 2003b: 272), cannot relate to. While his lack of paranoia (in both senses as paranoid reader and paranoid subject) makes him a seemingly stable male character (if he suffers from any anxiousness at all, it is class-anxiousness), it also rules him out as an object of desire.

Although the telegraphist cannot phrase those feelings in her everyday surroundings, or even admit them to herself, the heterotopian space of the seaside resort "down at Bournemouth" (James 2003b: 272) enables her to reflect on, and see more clearly her desires and opinions. Time, in this place, seems to be suspended, and the young woman is in a state of tranquil contemplation, "seeing many things, the things of the past year, fall together and connect themselves, undergo the happy relegation that transforms melancholy and misery, passion and effort, into experience and knowledge" (James 2003b: 273). In this liminal space, she realises what the narrative has, up to this point, already suggested, namely that she finds secrecy in others desirable because it gives her a sense of power: what bores her most in people is when "[t]hey don't seem to have a secret in the world" (James 2003b: 275). Those people coming into her office that pose a mystery make her feel powerful: "I've seen the thing through - I've got them all in my pocket." (James 2003b: 275) Her transparent future husband, in contrast, cannot arouse her interest.

Mr Mudge's character forecloses secrecy. The young woman even admits to him that she has met Captain Everard alone in a park. This act of confidence, however, does not make her bond more strongly with her fiancé. On the contrary, "telling him the whole truth that no one knew" (James 2003b: 275) only creates more distance between the two. Reflecting on her meeting the Captain in the park while sitting by the sea, the telegraphist connects the two liminal spaces that afford her a certain amount of freedom (both physically and mentally), a fact that $\mathrm{Mr}$ Mudge alludes to when he asks her: "Want you to sit with him in the Park?" (James 2003b: 276) In a manner more bold and free than she has displayed at any previous moment in the story, the protagonist admits to the pleasure she derives from making Captain Everard feel that she has got power over him: "He's in danger, and I wanted him to know I know it. It makes meeting him - at Cocker's, for it's that I want to stay on for - more interesting." (James 2003b: 276) It is also at this point that the young woman explicitly says what she thinks she has found out about that man, what she thinks his 'dark secret' contains: "He's in love with a lady - and it isn't right - and I've found him out." (James 2003b: 277) 
The way the telegraphist reveals all this to Mr Mudge is emphatically disinterested and neutral, as if she were rather talking to herself than to the man she could expect to be jealous. Instead, Mr Mudge is increasingly marginalised through her imagining the man that really fascinates her. The narrative as a whole confirms that the man who is not even present in this scene, through his having a secret, is superior to the transparent Mr Mudge, who does not grasp the nature of the feelings the young woman is expressing, and, instead, can only judge the situation in purely selfish, economic terms: "[W]hat will [Captain Everard] give $m e$ ? [...] I mean for waiting." (James 2003b: 277) The telegraphist makes this discrepancy explicit: "You're awfully inferior to him." (James 2003b: 276) Mr Mudge does not contradict her. In fact, he not once voices a strong opinion or seems moved, and is, in the end, linguistically eliminated: on his asking "Then where do I come in?", the telegraphist replies: "You don't come in at all. That's the beauty of it." (James 2003b: 277) For a brief moment, in the liminal space of the seaside, thinking back to her meeting the Captain in the park, and reflecting on her own real wishes and desires, the telegraphist fully realises the amount of pleasure and meaning she derives from the game of power she plays with the man with the secret. Mr Mudge's open nature and lack of mystery make him undesirable to her, and their relationship is reduced to being imagined in purely economic (and unexcitingly non-subversive) terms. At the end of their conversation by the sea, Mr Mudge takes back 'what is his:' he "presently overtook her and drew her arm into his own with a quiet force that expressed the serenity of possession" (James 2003b: 277).

\section{Thrilling Games of Power: The Telegraphist and Captain Everard}

The tale's central relationship, finally, is that between the young woman and the man whose secretive nature fascinates her: Captain Everard. While undoubtedly the object of the telegraphist's desire, James constructs him as an anti-hero, a troubled man, whose very paranoid nature makes him both attractive to the protagonist, and the object of the female characters' manipulative power games. Making him powerless both in economic and epistemological terms, James, aware of the precarious self-image of modern masculinities, subtly suggests that what makes his tale's men desirable is their lack of power, insofar as the women, who derive pleasure from being in control of the organisation of knowledge, can use it to their advantage.

It is, therefore, no coincidence that Captain Evarard is introduced to the story not by making an appearance himself, but through a woman who, due to the sheer mass of telegrams she sends, which are all signed with different names, and addressed to different people, impresses the telegraphist as a woman very much 'in 
charge.' This impression triggers a dynamic that reverses expectations of traditional gender roles. The telegraphist, in the tale's "most emphatically queer moment" (Keep 2011: 250), both admits that the woman, whose real name remains unclear, "was handsome, the handsomest woman, she felt in a moment, she had ever seen," eroticising "the living colour and splendour of the beautiful head" (James 2003b: 234), and takes up the challenge of matching this woman, who turns out to be Lady Bradeen, in her seemingly endless capacity for 'managing' people: the telegraphist "had seen all sorts of things and pieced together all sorts of mysteries" (James 2003b: 233). James here plays on the powerful cultural tradition of male rivalry as eroticised and mediated through a love triangle and the 'traffic in women,' and turns it on its head: the two women (as, similarly, the telegraphist and Mrs Jordan) are the rivals ("How little she knows, how little she knows! [...] How much $I$ know - how much I know!" [James 2003b: 259]), and Captain Everard (whom both turn out to desire) is the third part of the triangle, the man who mediates a dynamic that is primarily purely homosocial/homoerotic, a fact that is made explicit later in the story when Lady Bradeen visits again: "The girl looked straight through the cage at the eyes and lips that must so often have been so near his own - looked at them with a strange passion." (James 2003b: 258) The telegraphist's homoerotic gaze on Lady Bradeen shows that the narrative not only marks her as 'deviant' in epistemological terms, but also opens up possibilities of female queer desire. Kate Thomas observes

"that the doubleness of the telegraphist, and the more-than-doubleness of her clients produces queer effects that entangle her; her life is queer because it is postal. $[\ldots \mathrm{H}]$ er bending of the bars of the telegraphic cage, her entanglements in telegraphic wires, and the way gaps and blanks make her 'flash' throughout the story must be seen as themselves queer and queering." (Thomas 2012: 215)

When Captain Everard finally does make an appearance himself, it is in the company of Lady Bradeen. Only after she has 'introduced' the telegraphist to the Captain, the young woman's desire is redirected from the female to the male body. This process is, however, a somewhat conscious decision on the telegraphist's part: "[S] he had taken him in; she knew everything; she had made up her mind." (James 2003b: 236) This decision, while remaining ambiguous, entails a deliberate focus of her energies on the Captain and his secrets. This kind of desire, in its being, to some extent at least, a conscious decision, leaves the impression of being not an end in itself, but a means to derive pleasure from the game the young woman is about to play with this man that the other woman has introduced to her life, a game she could never play - and, hence, a pleasure she could never experience - with Mr Mudge. 
During their following intercourse, the telegraphist repeatedly stresses the feeling of growing power she derives from it. "Every time [Captain Everard] handed in a telegram it was an addition to her knowledge." (James 2003b: 253) She keeps looking for a chance "to show him in some sharp, sweet way that she had perfectly penetrated the greatest of" (James 2003b: 254) his secrets. Again, it is important to acknowledge the humorous undertones James employs to question the 'power' the young woman imagines to have. However, although the Captain's remark that the telegraphist has him "completely at her mercy" (James 2003b: 254) is clearly ironic, it is so in more than one way: the reader is aware that Captain Everard pokes gentle fun at the young woman, but also that this really is a relationship in which knowledge might make him blackmailable. The telegraphist makes this potential for danger explicit: "She quite thrilled herself with thinking what, with such a lot of material, a bad girl would do." (James 2003b: 255)

The subplot of the telegraphist's relationship with Captain Everard also sees another instant of a spatial movement from the respectable, masculine, capitalist indoors of the office, which does not allow for their relationship to develop (" $[\mathrm{H}]$ ow could he speak to her while she sat sandwiched there between the counter-clerk and the sounder?" [James 2003b: 256]), to the outdoors. She follows him to his place at Park Chambers in town, where she waits outside, looking at the windows, and feeling "as if, in the immense intimacy of this, they were, for the instant and the first time, face to face outside the cage" (James 2003b: 257). Although, in fact, actual physical intimacy is reduced, the mere reversal of positions (from his gazing at her through the bars of 'the cage' to her imagining to gaze at him thorough the windows) is enough for her to experience their situation as improved.

As Patricia McKee observes, James constructs the telegraphist's experience of the city's spatiality as emphatically 'other,' "a space that might have been different if different visions of it had prevailed, a space subject always to multiple configurations, only some of which achieve recognition as the way things are" (McKee 2008: 29). This London is a space of possibility, a space open to re-configurations and re-interpretations, and when Captain Everard and the young woman finally actually meet 'by accident,' the telegraphist - just as she needs to move to the seaside to be honest with herself and Mr Mudge - needs the liminal urban space of a park to open up to Captain Everard. This positioning of the female body in a liminal 'public' space also has a scandalous and subversive effect. "[N]o figure in late Victorian London was more equivocal than the woman in public." (Savoy 1995: 288) By making his female protagonist repeatedly move independently into the public, James associates her with the deviant type of the female prostitute, a woman on the margins (cf. Savoy 1995: 288-289). "Public women were, after all, encoded with a rhetoric of visibility that determined that women on display were necessarily advertising themselves for prostitution." (Nixon 1999: 189) While "the 
telegrapher's publicised body" (Galvan 2001: 297) alone invites associations with the deviant female body of the prostitute, the young woman's increasingly independent movement in public spaces makes her even more subversive.

Just as much as the telegraphist derives pleasure from 'finding out' the Captain's mysteries, she wants him to 'find her out:' "She had an intense desire he should know the type she really was without her doing anything so low as tell him." (James 2003b: 264) She wants the man she has chosen for her game to actively play along. At the same time, however, this is the only moment in which she realises that such reciprocity would leave her powerless. It is the only instant in the tale in which she loses control and starts to cry, completely surrendering her raised, self-confident position in admitting "I'd do anything for you. I'd do anything for you." (James 2003b: 268) She realises that her feeling of superiority very much depends on the Captain's being there for her to 'figure out.' At the same time, the telegraphist acknowledges that the amount of honesty the heterotopian qualities of the quasi-public, quasi-private space of the park afford her make her see both that Captain Everard will, just as Mr Mudge, not play her game after all (“[H]e wasn’t obliged to have an inferior cleverness - to have second-rate resources and virtues." [James 2003b: 267]), and that she needs the ambiguously restricting spatiality of her office to keep their relationship in a desirable equilibrium ("I mean [we cannot keep] meeting this way - only this way. At my place there - that I've got nothing to do with, and I hope of course you'll turn up, with your correspondence [Lady Bradeen] when it suits you." [James 2003b: 267]). The game of power that both are involved in very much depends on the socially charged 'public' space of the workplace.

The frankness the telegraphist allows herself to display in the park does, however, enable her to explicate the nature of the bond that the sharing of knowledge between the two of them entails: "This is what I meant when I said to you just now that I 'knew.' [...T] hat knowledge has been for me, and I seemed to see it was for you, as if there were something - I don't know what to call it! - between us." (James 2003b: 267) Here, James has his protagonist perform a powerful rhetorical move. So far, it seemed as if her influence over the Captain relied mainly on her 'knowing' things about him, playing on the possibility of blackmail so famously associated with the contemporary homosexual scandals of the Wild trials and the Cleeveland Street Scandal (cf. Stevens 1998: 128-132). Now, she additionally employs a rhetoric of (traditionally homosocial) secret sharing (which, in this context, becomes ambiguously heterosocial/-sexual), turning her moment of apparent weakness into a reinforcement of her (albeit still mainly imaginary) power over Captain Everard. This is further emphasised by the young woman's actually making herself, their relationship, and their shared 'knowledge' both a shared secret, and the Captain's secret, deliberately forcing herself, as it were, into his 'closet:' 
“'Have you ever spoken of me?' 'Spoken of you?' 'Of my being there - of my knowing, and that sort of thing.' 'Oh, never to a human creature!' he eagerly declared." (James 2003b: 268) In a rare instance of narrative insight into the Captain's thoughts, James has him acknowledge the impression this makes on his male 'hero:' "She held him, and he was astonished at the force of it." (James 2003b: 268)

James draws attention to the discrepancy between "what counts as the telegraphist's knowledge, and its indirect relation to what circulates among the characters as the performative effect of that knowledge" (Savoy 1995: 286). During their encounter in the park, the reader, as opposed to the young woman herself, becomes aware of her making Captain Everard acutely conscious of his blackmailability by this female public servant, although she herself consciously decides against doing just that, because she is not a 'bad girl.' James celebrates - always with an ironic twist to it - the power of a rhetoric of knowledge that works almost independently from any actual exchange of information. The signifiers alone suffice to trigger paranoia. It is crucial that James makes a woman mistress of this game of power, subtly - and with a wink - suggesting the subversive potential of a woman 'managing' the patriarchs around her, playing on their masculine self-definition based on issues of (always potentially paranoid) secrecy in a culture increasingly concerned with questions of deviant male sexuality, and "obsessed with naming, while making public naming a matter of great risk" (Stevens 1998: 131-132). Although the young woman denies any intent to blackmail, she nevertheless achieves this effect, precisely because Captain Everard's paranoia must make him read her rhetoric in that way. "Whatever she thinks she knows and however wrong it may be, she nonetheless has touched the one region in which the ruling class is vulnerable its control and command of language." (Rowe 2000: 88) Unable to make his own paranoid knowledge of his 'sexual secret' explicit (he cannot be absolutely sure of what exactly she knows), he can only acknowledge the powerful impression the telegraphist's rhetoric has on him: "'You're awfully clever, you know; cleverer, cleverer, cleverer -!' [...] 'Cleverer than who?"' (James 2003b: 269), asks the young woman. It is for the reader to fill in the gap: cleverer than Lady Bradeen, cleverer than any woman the Captain knows, cleverer than any man even; and the Captain admits: "Well, if I wasn't afraid you'd think I'd swagger, I should say - than anybody!" (James 2003b: 269) This cleverness makes the young woman dangerous in a world ruled by the patriarchal, male-homosocial system of secret sharing that traditionally excludes women from the exchange of knowledge, and that is increasingly in danger of being read 'queer' by the paranoid reader.

The telegraphist, having established this close bond between herself and the Captain, goes on to explicitly making him aware of the pleasure she derives from the power she believes to have: "I like all the horrors. [...] Those you all - you know the set I mean, your set - show me with as good a conscience as if I had no 
more feeling than a letterbox. [...They d]on't know I'm not stupid[.] No, how should they?" (James 2003b: 270) The young woman makes Captain Everard see that her power goes beyond a mere gendered power game between the two of them. Her position, she believes, potentially subverts the whole of those higher classes that are ignorant of the ways she (believes she) could use their knowledge against them. She 'knows' all of their weaknesses, "[y]our extravagance, your selfishness, your immorality, your crimes" (James 2003b: 270). While not directly influencing these people's lives, the telegraphist is conscious of "the harmless pleasure of knowing. I know, I know, I know!” (James 2003b: 271) This 'harmless pleasure' is, of course, not harmless at all, particularly for men. Oscar Wilde is the best example.

James never lets the game of power between the telegraphist and Captain Everard go beyond the mere pleasure of rhetoric, and the telegraphist herself admits that "to be in the cage had suddenly become her safety, and she was literally afraid of the alternate self who might be waiting outside" (James 2003b: 282), again acknowledging her 'caged-in' spatial situation as the only one in which she is afforded a certain amount of actual influence. "[T]he power the telegraphist possesses crucially depends on the position in the social sphere that she inhabits: only by virtue of her place in the cage can she achieve such control over those outside the cage." (Buelens 2006: 130) James does, however, afford his protagonist one moment in which she literally exerts power over the Captain by withholding knowledge from him. Only 'in the cage' can she feel that the Captain "only fidgeted and floundered in his want of power," and when he comes back for his final request, it is "with a face so different and new, so upset and anxious" (James 2003b: 284-85). Back in a position of power in "her role as public servant [...that affords] her to protect the secrecy of telegraph messages" (Moody 1995: 64), and manage this information according to her own interests, the telegraphist feels that the Captain needs her, "like a frightened child coming to its mother" (James 2003b: 286). The Captain, exposed to the psychological mechanisms of paranoia that the telegraphist's rhetoric has triggered in him, indeed has to admit to exactly the kind of discrepancy in power that has been hinted at so many times in the story. He needs to recover a telegram: "There was something in it that has to be recovered. Something very, very important." (James 2003b: 287) At this moment, the girl finally has him where she wants him. She knows something he needs, and he depends on her to tell him; he is in her power: "[S]he could almost play with him and with her new-born joy." (James 2003b: 288) James has his protagonist enjoy this moment, making her play with her power, not immediately revealing what she knows, watching the Captain suffer: it was "the deepest thrill she had ever felt. [...S]he held the whole thing in her hand. [...] This made her feel like the very fountain of fate." (James 2003b: 287) This is her final triumph, her moment of greatest power: "She continued to hold him, she felt at present, as she had never held him; and her 
command of her colleagues was, for the moment, not less marked." (James 2003b: 290) Strikingly, the young woman achieves this moment of triumph by acting out the very function that is expected of her: she "derives jouissance from the performance of a socially prescribed role" (Buelens 2006: 134), aware both of her power over Captain Everard, and of the socially conditioned spatial and professional situation that affords her this power in the first place. In a way, hence, she breaks free from social conventions, because her performance, "in its hyperbole, actually explodes the stereotype and instead works the gap between role and performance" (Buelens 2006: 134).

The moment, of course, does not last, and everything the telegraphist has imagined to 'know' is abruptly reduced to absurdity in her final confrontation with Mrs Jordan as described above. All this, however, does not diminish the effect this experiment in the power of a rhetoric of secrecy and knowledge has on the reader. On the contrary, the effect is starkly contrasted with the fact that, actually, the telegraphist does not 'know' anything, which draws even more attention to this rhetoric's independence of actual content: power through knowledge is derived mainly from a language of knowledge. What that knowledge actually is turns out to be only secondary. As Kate Thomas observes, James emphasises the act of communication as being much more important than what is actually communicated: "The content of [the] many telegrams [...] is meaningless. [...] Although there is zero content in these exchanges, there is plenty of relation." (Thomas 2012: 208) In the young telegraphist, James creates a character who, while never actually breaking free from the social conventions that restrict her (in terms of both class and gender), is very much aware both of the performative nature of a rhetoric of secrecy, and of the structure of a social spatiality that simultaneously restricts and empowers her. She might not be able to change the rules of the game, but she plays it expertly - at least for a moment. From an economic point of view, she has to realise that her profession reduces her to "just another object available for [the aristocrats'] frivolous purchase and enjoyment," and the alternative she opts for in the end is another form of female objectification as "the conjugal possession of $\mathrm{Mr}$. Mudge" (Galvan 2001: 304; 305), the marriage to whom will also end her time as a working woman, re-integrating her, as it were, into the safe sphere of domesticity. While, however, James acknowledges this late Victorian woman's inescapable objectification in terms of the economies of money, he empowers her in terms of the economies of knowledge as paranoid reader.

Although James does not take his little story and its characters too seriously, and repeatedly pokes gentle fun at his heroine's ambitions and imagination, he does, nevertheless, get the message across: knowledge is (potential) power, particularly when negotiated through a rhetoric of secrecy that evokes the paranoid 'closet,' a rhetoric that lies on the border between speaking and not speaking, be- 
tween knowing and not knowing. The 'closet,' as James demonstrates in "In the Cage," is "a performative space of discretion that occupies a liminal position between the private and the public, between secrecy and the imperative to represent" (Savoy 1995: 297). James constructs a masculinity whose paranoia is reminiscent of the paranoid Gothic of the Bluebeard kind, but now takes on an additional dimension in that it reverberates with contemporary discourses on the homosexual 'closet.' His neo-Gothic protagonist not only tries to invade the masculine 'closet,' but has learned to become a multiply subversive force in her movement in space, and her deliberate employment of a powerful 'closet' rhetoric. The way James constructs space to serve his point reflects his awareness of the metaphorical qualities of the inside and the outside, the public and the private, the central and the liminal, and a tradition of gendered spatiality that goes back to the earliest novels in literary history.

In the context of contemporary discourses on sexual identities, his rhetoric takes on another dimension: "Sexuality [...] becomes irretrievably a question of style and intonation, not of depth." (Laughlin 2010: 156) James, "fascinated by the incoherence, the polymorphousness, of identity" (Stevens 1998: 132), and aware of an historically ever-increasing need to 'read' people's 'sexualities,' denies his readers just such definite readings, emphasising the power of a rhetoric of secrecy that defies definite meaning. "In the Cage" illustrates the moment in (literary) history at which a more general masculine paranoid 'closet' starts to get sexualised, and becomes the 'closet.' James' 'closet,' however, is not simply 'homosexual,' but emphatically 'queer.' The space of telegraphic exchange is the ideal place for this ambiguous 'flirtation' with knowledge. James “delineates a relationship between the post and the closet: both are capacious and both have a swinging door between the public and the private. James relishes this swing and wants little to do with efforts to pin the door either open or shut" (Thomas 2012: 220). He constructs both his female protagonist and his reader as 'paranoid readers,' locating the psychologically damaging effects of paranoia in his male anti-hero. The reader, however - and the paranoid reader in particular - is always also a writer: just as the protagonist uses her 'readings' of the people around her and their telegrams to create her own fictional romance (cf. Vaux 2001), the reader/writer of fiction, and the 'reader'/“writer' of 'real' people, in their "excessive subjectivity" (Vaux 2001: 133), are always on the lookout for (a fantasy of) meaning, and this meaning, especially at the turn of the nineteenth century, is likely to be construed as 'sexual.' In his tale of the female paranoid reader and the male paranoid 'closet,' James not only dramatises a "crisis of interpretation [...] that is innate to the experience of reading modernist fiction" (Olson 2009: 244), but one that is also innate to the experience of modern masculinities. 


\section{Autoerotic Paranoia in the 'Closet:' Henry James' "The Jolly Corner"}

James' short American tale "The Jolly Corner" returns the 'closet' to its literary roots in the fictional architectural spaces of the Gothic. Its protagonist, Spencer Brydon, comes back to America after thirty-three years in Europe. Following the death of all his relatives, he has inherited the family mansion in New York, "his house on the jolly corner, as he usually, quite fondly described it" (James 2003C: 342). This house becomes the space in which Brydon haunts and is haunted by his 'alter ego,' the past self he left behind when he went to Europe, the man he could have been. James, in a "complete exercise in the psycho-dynamics of place" (Hardy 1997: 192), constructs the 'closet' as both metaphor and actual space, in a rhetoric that is reflected in the intricate architecture of upstairs and downstairs, the back rooms, doors, windows, and passage ways of the house. Far from ever making homosexuality an explicit issue, James creates an interpretative void, a linguistic space of allusions, drawing heavily on the rhetoric of the 'open secret.' "James's signalling of Brydon's homosexuality takes the oblique form of connotation, but the play of connotation is sufficiently elaborate to acquire a solidity and a specificity in differential relation to the signs of heteronormative American masculinity." (Savoy 1999: 2) As in earlier tales, James employs a language that calls for being filled with 'meaning,' creating a secret which, at the turn of the twentieth century, must reverberate with sexual implications. In this late piece of fiction, however, he goes a step further: both de-sexualising the tale's apparently heterosexual sub-plot between Brydon and his friend Alice Staverton, and making her a woman who seems to 'know' more about the protagonist than he does about himself, James makes the question of Brydon's position as 'masculine' and 'heterosexual' man more than conspicuous. Staging his protagonist's crisis in a space reminiscent of early Gothic domesticity, he makes Brydon a modern Bluebeard, a man who knows that his secret is not - and never has been - safe. Brydon is also, however, crucially different from his paranoid 'predecessors:' as one of the first male characters in this tradition - and in the face of women who are 'in the know,' but pose no threat, and a desire that becomes increasingly nameable - he contemplates 'coming out,' facing his 'closeted' alter ego, and embracing his 'difference.' Although, in the end, Brydon does not 'come out,' and James has him ostensibly return to the safe haven of heternormativity, this tale presents paranoid masculinity as a choice, and asks what an alternative might be. Relishing the very impossibility of naming Brydon's secret, James both celebrates and questions a 'queer space' that defies definite signification. 


\section{Return to the 'Queer House'}

The house itself is introduced at the beginning of the tale - in a similar fashion to the palazzo in "The Aspern Papers" - as a mansion that is clearly not the symbol of patriarchal power and inherited strength that it might be expected to be. The protagonist, at least, refuses to inscribe himself into that tradition, and retains an ironic distance: "He had come - putting the thing pompously - to look at his 'property,' [...] he had yielded to the humour of seeing again his house on the jolly corner." (James 2003c: 342) Brydon assumes no attitude of presumably 'masculine' pride in ownership, and the adjective 'jolly' brings to mind associations of fun, festivity, joy, and pleasure, rather than sombre pride and dignity: the 'jolly corner' is explicitly contrasted with "the comparatively conservative Avenue" (James 2003c: 345). At the same time, however, although "alienated" (James 2003c: 342) from his ancestral home, Brydon's income from renting out this and a second house in New York has afforded him to "live in "Europe" (James 2003c: 342), the inverted commas around 'Europe' drawing attention to its standing for the symbolic difference and emphatic separation of the life that he chose from what he left behind in America.

Similarly, Brydon's two houses in New York both, in their own way, stand for the contrast between the life he has lived, and the life he denied himself. The house on the 'jolly corner,' as we shall see later, symbolises both the emptiness of the life he chose, and the ghost of his 'closeted' existence; the other house, "already in course of reconstruction as a tall mass of flats" (James 2003c: 342), both serves as a means for Brydon to realise the "lively stir [...that] had been dormant in his own organism" (James 2003c: 343), a reminder of the life he could have lead, associating his 'missed career' with the modern, masculine, capitalist occupation of 'erecting' new buildings, and, in its contrast with the old, haunted, 'other' house that is the actual focus of his attention, demonstrates that the 'lively' stir might in fact be something else.

The regret, the feeling of having missed a chance, "the queerest and deepest of his own latterly most disguised and most muffled vibrations" (James 2003c: 344), is immediately phrased in terms of the spatiality of the Gothic domestic: the feeling haunts him "very much as he might have been met by some strange figure, some unexpected occupant, at a turn of the dim passage of an empty house" (James 2003c: 344). His 'alter ego,' as Brydon will call it himself later, is a personified ghost, a forgotten version of himself, and this self is indeed 'closeted,' found on "opening a door[...,] some quite erect confronting presence" (James 2003c: 345).

Brydon's relationship with his house on the 'jolly corner' is clearly odd. Not only does he prefer "to leave the place empty," but, without intending to live in it, he also goes there "absurdly often" (James 2003c: 345). The only other person 
having access to the house is Mrs Maldoon, "a good woman living in the neighbourhood" (James 2003c: 345), who comes to clean the place. Although Brydon is called the house's "master" (James 2003c: 345) in this passage, it is the only time in the tale he is referred to as such, and his position of actual authority is questioned by his impulse to keep his nocturnal visits to the place a secret, even from his housekeeper, hiding candles "at the back of a drawer of the fine old sideboard that occupied [...] the deepest recess in the dining room" (James 2003c: 346). Brydon actively avoids taking possession of the house's spatiality as the patriarchal owner that he actually is. Instead, he makes himself, as it were, the 'closeted' secret of his own house, deliberately putting himself in the position of the Gothic heroine of the type of Emily in Udolpho. Brydon does not want the house to enable him to be the patriarch; quite the contrary: he "can afford for a while to be sentimental here!" (James 2003c: 346).

It becomes increasingly clear, however, that James constructs here not a juxtaposition of the patriarchal home with the feminised, sentimental, 'queer' sensitivity of his protagonist, but, instead, places the latter at the very centre of the mansion: Brydon remarks that he "might have lived here," and, had he done so, "everything would have been different enough - and, I dare say, 'funny' enough" (James 2003c: 347). 'Funny' how? And how does this alternative, 'funny' existence in the house at the 'jolly corner' relate to Brydon's "perversity" (James 2003c: 347)? In creating an unusual linguistic connection between expressions of deviance and joy that all carry potentially 'sexual' meanings, and relating them to the architecture of the abandoned house, James locates Brydon's 'queer' identity at the very centre of patriarchal domesticity, suggesting that, far from being a marginal phenomenon, 'sexual' deviance and 'queer' possibility are constitutive of patriarchal masculinity.

This potential for deviance is further emphasised by James' constructing the house as a liminal space, "a non-place characterized by [a] hugely suggestive absence" (Nixon 2004: 811), "a space neither here nor there" (Zwinger 2008: 7), stripping it of the rules of socially sanctioned domesticity. Being completely empty, the house enables Brydon to imagine his own version of it, according to his desires: "For me it is lived in. For me it is furnished." (James 2003c: 348) He also explicitly contrasts the house's imaginary qualities with "the comparatively harsh actuality of the Avenue," and even alludes to the emphatically liminal image of the emergence from "an Egyptian tomb" (James 2003c: 348) to characterise this juxtaposition.

James depicts the house as a spatiality that simultaneously alludes to an imagery of patriarchal lineage and traditional domesticity (Brydon "let himself in and let himself out with the assurance of calm proprietorship" [James 2003c: 352].), and bears the secret to an alternative life that the tale's protagonist might have 
led. The house is at once Brydon's 'closet,' haunted by his "strange alter ego" (James 2003c: 349), and the enabling space that triggers contemplation on what this 'closet' means: being in the house makes Brydon reflect on his life choices, and provokes melancholia; he starts brooding over "the question of what he personally might have been, how he might have led his life and 'turned out,' if he had not so, at the outset, given it up" (James 2003c: 348). While what 'it' is remains ambiguous, Brydon clearly is aware that there are people who have embraced 'it' ("I see what it has made of dozens of others." [James 2003c: 348]), leading the life he has denied himself. On the surface, this passage alludes to his possibly becoming a successful businessman, the embodiment of American, capitalist, masculine strength. By employing an ambiguous rhetoric, however, and by constantly associating 'it' and the life that Brydon never lived (that "fantastic, yet perfectly possible, development of my own nature I mayn't have missed" [James 2003c: 349]) with "his stifled perversity" (James 2003c: 351), and his "abysmal conceit of [his] own preference" (James 2003c: 349), James subverts these capitalist associations, which are, as many critics have remarked on, so present in "the commercial language that pervades the text" (Nixon 2004: 810), with the language of the 'open secret' that will always invite 'sexual' readings. This powerful interpretative draw becomes even more prominent in the way James constructs the character and rhetoric of Alice Staverton.

\section{Heterosociality and the 'Open Secret:' Alice Staverton}

The narrative introduces Alice Staverton as an independent, and markedly unusual woman. She owns her own house, the address of which, "in Irving Place" (James 2003c: 343), is the only one in the tale to be explicitly mentioned. She and her house are a point of stability for Brydon, the house being "a small still scene where items and shades, all delicate things, kept the sharpness of the notes of a high voice perfectly trained, and where economy hung about like the scent of a garden" (James 2003c: 343). Where Brydon is searching and restless, Miss Staverton seems to have found an existence in equilibrium. Ostensibly Brydon's heterosexual love interest, James de-sexualises their relationship from the start, making her at once fascinating and strange, "a fair young woman who looked older through trouble, or a fine smooth older one who looked young through successful indifference" (James 2003c: 344). Rather than being eroticised, Miss Staverton is a friend whose femininity is glorified not as something to be desired sexually, but as something to find stability, calm, and trust in. The relationship between her and Brydon is not 'heterosexual,' but heterosocial: "They had communities of knowledge, 'their' knowledge." (James 2003c: 344) 
Miss Staverton is repeatedly, indeed excessively, referred to as a woman 'in the know.' Her relationship with Brydon is dominated by a seemingly complete understanding of her friend that does not need to be explained in words. She even seems to understand his thoughts and actions better than he does himself, an impression she gives through "the particular mild irony with which he found half her talk suffused" (James 2003c: 346). Her language is full of ellipses and things unsaid: "[T] hings she didn't utter, it was clear, came and went in her mind." (James 2003c: 348) She employs the rhetoric of the 'open secret,' confidently aware of what she seems to 'know' about Brydon. It is crucial to observe, however, that she never shares what she thinks she knows with him. Knowing more about his 'queer existence' than he does himself puts her in a position of power. She does not, however, take advantage of that position: "[S]he was a woman who answered intimately but who utterly didn't chatter." (James 2003c: 347) With Alice Staverton, James constructs a female character who has penetrated the workings of paranoid, 'queer' masculinity, but who becomes neither a 'female helper,' nor a threat, but instead remains calmly observant, only subtly instigating Brydon's quest for self-knowledge through a conscious employment of the fascination of the unsaid: "[H]er untold reading of Brydon haunts his readings. [...] It is [her] who first invokes, conjures, narrates [...] the other Brydon into existence." (Zwinger 2008: 10; 12)

There are only a few instances in which Miss Staverton actively tries to influence Brydon, assuring him that she believes in what he could have been, could still be, that she knows about and believes in his 'queer existence' and its potential: "I believe in the flower [the 'alter ego']. [...] I feel it would have been quite splendid, quite huge and monstrous." (James 2003c: 349) This is also the only moment at which James, through his female character, explicitly questions the surface reading of Brydon's alternative existence as capitalist patriarch: "YYou'd have liked me that way?' he asked. She barely hung fire. 'How should I not have liked you?' 'I see. You'd have liked me, have preferred me, a billionaire!' 'How should I not have liked you?' she simply again asked." (James 2003c: 350) Both keeping their relationship on a level of friendship ('like' not 'love'), and curiously denying to react to Brydon's reading of his own 'alter ego,' Miss Staverton makes him - and the reader - aware of his self-delusion: the 'alter ego' must be 'something else.'

The 'alter ego,' the tale's supernatural element, is the allegory through which Miss Staverton can give her knowledge of Brydon shape. The fact that "she divined his strange sense," and her "apparent understanding" (James 2003c: 350) take on an almost physical quality when she admits to have seen Brydon's 'alter ego' in a dream. Again, however, she is reluctant to share all her 'knowledge' with the man it concerns: “"Then you know all about him.' And as she said nothing more: 'What's the wretch like?' She hesitated, and it was as if he were pressing her so hard that, resisting for reasons of her own, she had to turn away. 'I'll tell you some 
other time!"' (James 2003c: 351) The irony here is that James' rhetoric implies that the rules of the 'open secret' have to be adhered to: although Miss Staverton 'knows,' she cannot simply make this knowledge explicit, for it is knowledge that cannot be spoken - or rather the 'closet' becomes 'known' only by speaking about it as a secret. James does not have to make Brydon's 'alter ego' explicitly 'queer;' the rhetoric he employs to so markedly not do just that is more than sufficient. Alice Staverton must play her part, but her knowing smiles, reassuring hints, and motherly concern make the question as to what she knows so exaggeratedly pressing that it becomes almost redundant.

The tale's ending, although apparently depicting the heterosexual fulfilment of Brydon and Miss Staverton's relationship, picks up the theme of motherly femininity again, and ultimately makes it almost impossible for the reader to imagine any actual sexual consummation of the heteronormative plot, which, in the end, defeats itself. Having confronted, and finally - as we shall see later - rejected his 'queer alter ego,' Brydon is found and woken up from unconsciousness by the story's two female characters. Strongly playing on the imagery of a scene of (re)birth (He is "lifted and carefully borne as from [...] the uttermost end of an interminable grey passage" [James 2003c: 366].), James ironically suggests Brydon's awakening to an ultimate acceptance of a heteronormative life, and a confirmation of the politics of the 'closet." "[H]alf-raised and upheld," however, he wakes up like a child in his mother's arms, with his "head pillowed in extraordinary softness and faintly refreshing fragrance” (James 2003c: 365). Again, James' choice of words forecloses any normatively eroticised reading of the relationship between Brydon and Alice Staverton. He is only "conscious [...] of tenderness and support" (James 2003c: 365). Brydon is both infantilised ("Alice Staverton had made her lap an ample and perfect cushion to him." [James 2003c: 365]), and feminised, in that he completely gives in, "so gratefully, so abysmally passive" (James 2003c: 365), to a physicality that contradicts powerful notions of the very capitalist, active masculinity he has pretended to want to inscribe himself into. Hence, although rejecting his 'queer alter ego,' Brydon, in fact, only moves on to another kind of 'queer' - non-heterosexual, non-normative - existence.

While the characters' physical demeanour suggests the impossibility of a heternormative ending, Brydon rhetorically glorifies his 're-birth' as a return to knowledge of his heterosexual destiny. The terms, however, in which he praises Miss Staverton uncannily suggest his realisation that she is much more his 'mother,' who has helped him acknowledge his nature (which he continues to deny), than an object of desire: "You brought me literally to life." (James 2003c: 366) Miss Staverton is not only de-sexualised (in strictly procreative terms) as Brydon's 'mother,' but this image takes on almost iconographic dimensions when she becomes the Virgin Mary, the Christian embodiment of sexual impenetrabil- 
ity, who has brought her son back from the dead (Brydon says, "I can only have died" [James 2003c: 366].), and whose "cool charity and virtue of [...] lips" (James 2003c: 366) denies being physically consummated by her 'son'/the 'queerly' penetrated body of Jesus.

In the end, Brydon remains in denial: "There's somebody - an awful beast. [...] But it's not me." (James 2003c: 367) Miss Staverton, who has "known, all along" (James 2003c: 367), accepts his denial as the only socially possible choice: he sees in her face "some particular meaning blurred by a smile. '[...]Of course it wasn't to have been."' (James 2003c: 367) Both accept that, socially, their fate has to be the heteronormative fulfilment of the marriage plot: "'And now I keep you,' she said. 'Oh keep me, keep me!' [...] It was the seal of their situation.” (James 2003c: 36667) James does, however, have Miss Staverton explicitly deny the horror Brydon feels in remembering his 'alter ego:' “[W]hy [...] shouldn't I like him? [...] I could have liked him. And to me [...] he was no horror. I had accepted him [...] I pitied him." (James 2003c: 369) In Miss Staverton, James constructs a femininity that has penetrated the 'closet' of masculinity, but, far from entering into a dualistic power struggle, accepts the possibility of 'queer secrecy' with a benevolent smile. While, in this tale, any erotic fulfilment is ruled out, James does posit an alternative to paranoid masculinity, and the 'closeting' of a 'queer' existence, which, while not yet liveable, becomes at least conceivable.

\section{Confronting the 'Other' in the Gothic 'Closet:' The Eroticised Chase of the 'Alter Ego'}

The tale's core is Brydon's solitary nocturnal visit to the house, in which dichotomies of private and public, open and closed spaces take on a powerful significance. The house's spatiality can only serve Brydon as a catalyst for a "surrender to his obsession" (James 2003c: 351) at night, and, more specifically, at the transitional moments "of gathering dusk, of the short autumn twilight" (James 2003c: 351). These in-between times enable Brydon to "let himself go" (James 2003c: 351); their liminal, dream-like nature changes his perception of the house's architecture, and the lines between private and public, open and closed blur: the private space of "the great vague place" suddenly opens up, and displays "open vistas, reaches of communication between rooms and by passages" (James 2003c: 351). The domestic turns into the open landscape of Brydon's chase: “[H]is odd pastime was the desire to waylay and meet" (James 2003c: 353) his 'alter ego.' This desire is eroticised and fetishised as Brydon's thrilling obsession: "[H]e had tasted of no pleasure so fine as his actual tension, had been introduced to no sport that demanded at once the patience and the nerve of this stalking of a creature more subtle, yet 
at bay perhaps more formidable, than any beast of the forest." (James 2003c: 353) The narrator compares the house's 'landscape' to the wild outdoors, and Brydon's externalised 'other' self becomes both object of his desire to possess, and object of his wish to destroy. More specifically, the 'hunt' itself is eroticised, and hence keeping in mind the function of the 'alter ego' as Brydon's alternative, rejected self - the workings of the 'closet' as a psychological mechanism are equally charged with erotic tension. Brydon's 'closet,' although staged as an uninhabitable domestic space, is fetishised as a desirable state of liminality.

This liminal state also questions and destabilises conventional roles and relations. Identities are reversed, and it becomes increasingly less clear who is haunted, and who haunts: Brydon has "turned the tables and become himself, in the apparitional world, an incalculable terror [...for] the poor hard-pressed alter ego" (James 2003c: 354). What Brydon finds desirable about this state, however, is not the power he gains, but the very loss of control he can allow himself to experience: "He was kept in sight while remaining himself - as regards the essence of his position - sightless." (James 2003c: 355) Brydon is made the object of a (strangely auto-erotic) male gaze, which disempowers and feminises him in a way very much reminiscent of the female Gothic. In a similar reversal, the narrative focus shifts back and forth between an emphasis on the open and enabling nature of the house's landscape ("He liked [...] the open shutters." [James 2003c: 354]), and a penetrative fascination with its intricate architecture 'in the back:' "[N]one the less often the rear of the house affected him as the very jungle of his prey." (James 2003c: 354) While evoking - in a similar fashion to the editor's penetration of the back garden in "The Aspern Papers" - a very physical imagery of anal fixation, this passage also alludes to a voyeuristic fascination with modern privacy, and, again, the house's spatiality mirrors the space of Brydon's mind, in which he has 'hidden' his 'alter ego:' in the back, "[t] he place was [...] more subdivided; a large 'extension' in particular, where small rooms for servants had been multiplied, abounded in nooks and corners, in closets and passages" (James 2003c: 354). Brydon walks the 'closets and passages' of his secret thoughts just as much as he secretly discovers the 'nooks and corners' of the house's actual space.

When Brydon finally confronts his 'alter ego,' the narrative positively overflows with descriptions of his physical reactions to the situation, which oscillate between stress and excitement, and of a continued negotiation of the confrontation through the house's architecture. "[H]e seemed all of a sudden to know what now was involved." (James 2003c: 356) Deliberately ambiguous, the narrative does not clarify exactly 'what' is involved. James' typical over-use of inverted commas does not produce meaning, but evokes associative, non-linear 'meaning-making' reactions in the reader: "I've come, as they say, 'to stay.' [...] I've hunted him till he has 'turned."' (James 2003c: 356) Lee Clark Mitchell, in his formalist analysis 
of the tale, shows how James' excessive use of scare quotes mirrors and reinforces epistemological processes at the level of content: the scare quotes "question[] [a term's] conventional denotations and thus transform[] a more or less literal statement into a figurative one. [...] Brydon exposes a range of possibilities inherent in any language that never quite means what it says." (Mitchell 2007: 225; 228) This is the very effect that crucially characterises the rhetoric of the 'closet.'

Brydon is about to face the epistemological crisis of 'coming out,' and his physical reactions emphasise the fundamental nature of this crisis: "[H]e had broken into a sweat. [...It was] a sensation more complex than had ever before found itself consistent with sanity." (James 2003c: 356) This moment of fundamental choice whether or not to embrace the 'closeted alter ego' - confronts Bryon with fear and excitement, and, for a moment, he considers a reunion with his suppressed self: "[T]his ineffable identity was thus in the last resort not unworthy of him. [...] It was as if it would have shamed him that [...his 'alter ego'] should to the end not risk the open. [...He felt] the vivid impulse, above all, to move, to act, to charge, somehow and upon something - to show himself, in a word, that he wasn't afraid." (James 2003c: 357)

This crisis of choice is reflected in the way James stages Brydon's chase of the 'alter ego' within the house. Rejecting a model of chivalric masculinity from "an age of greater romance," still dominant in the early Gothic, the "heroic time" in which a man would "have proceeded downstairs with a drawn sword in his other grasp" (James 2003c: 357), as almost comically inadequate, Brydon proceeds to confront his 'alter ego' with a candle that "would have to figure his sword" (James 2003c: 358). The phallic sword is substituted with the phallic candle, the former representing a masculinity relying on brute strength, the latter putting an emphasis on the 'enlightening' power of knowledge. This substitution, at the same time, again refers to the image of the candle-carrying, castle-exploring Gothic heroine, feminising Brydon's attitude towards the dangers he fears to encounter. Spatially, he has reached the innermost part of the maze-like house; an overwhelming "multiplication of doors" (James 2003c: 359) and corridors reflects the transitional stage Brydon is going through: "The door between the rooms was open, and from the second another door opened to a third[..., and] there was a fourth, beyond them, without issue save through the proceeding." (James 2003c: 358) Brydon's remarking on "the violent shock of having ceased happily to forget" (James 2003c: 358) reflects that the passage through these multiple doors is closely associated with a process of recognition. In the 'closet' behind the doors, he is about to confront what he has tried to suppress.

The act of opening the last door comes to stand for the ultimate confrontation with Brydon's rejected past. The narrator comments on this exaggerated conflation of the metaphor of the 'closet' with its actual spatial origins: "The house, as the 
case stood, admirably lent itself." (James 2003c: 358) This is, in fact, the whole purpose of the house: to lend itself as the spatial metaphor of Brydon's mental crisis, as the actual locus in which James can stage this epistemological dilemma. Finally confronted with the choice whether or not to open the door, Brydon realises that this is a "question of courage[...:] [S]hould he just push it open or not?" (James 2003c: 359) In the end, he decides not to, and lets the 'closet' remain unopened. It is crucial, however, not to overlook that the narrative does not absolutely condemn this lack of courage. Just as the chase itself was eroticised earlier, Brydon now draws attention to "the value of Discretion" (James 2003c: 359), an excuse, however, that is exposed as just that by Brydon's eagerly "jump[ing] at that" (James 2003c: 359). This moment of ambiguity and ultimate resignation is the only point in the tale at which the narrator assumes the first person, emphasising the particular importance of this choice as the story's central issue, summarised in Brydon's plea: "I retire, I renounce - never, on my honour, to try again. So rest for ever - and let me!" (James 2003c: 360)

Having built up extreme suspense and tension over his protagonist's inner crisis, and elaborately creating an instant of absolute epistemological possibility the knowledge at stake bearing the potential to change Brydon's life - James has his protagonist withdraw. Making the opening of the 'closet' graspable, he opts against it. What follows is resignation: "His spell was broken now." (James 2003c: 360) Brydon willingly embraces his daytime existence, ruled by social constraints: "The empty street - its other life so marked even by the great lamplit vacancy was within call, within touch." (James 2003c: 360) Instead of finally 'knowing' himself (the candle, his 'light of knowledge,' "burnt [...] well-nigh to the socket" [James 2003c: 360]), he is ready to be interpellated - in a most literally Althusserian way - by the society he is ultimately unwilling to be cast out from: " $[\mathrm{H}] \mathrm{e}$ would have welcomed positively the slow approach of his friend the policeman, whom he had hitherto sought to avoid, [... of] the patrol [...he] felt the impulse to get into relation with [...], to hail." (James 2003c: 360) The feeling of belonging and community, however, comes at the price of paranoia: he wants to "save[] his dignity and [keep] his name out of the papers. [...H] e was so occupied with the thought of recording his Discretion [...] that the importance of this loomed large." (James 2003c: 360) The choice is between the street and the house, between confronting one's 'alter ego' at the risk of crisis and scandal, and social acceptability at the price of paranoia.

Society, however, will ultimately not provide Brydon with the sense of community he is looking for. "His choked appeal from his open window" is met by the unwelcoming, quasi-human 'gaze' of the "hard-faced house, [...g]reat builded voids, great crowded stillness put on" (James 2003c: 361). Brydon is conscious that he cannot help being a stranger in a society that is obsessed with privacy, and 
simultaneously polices everybody's privacy according to certain (sexual) morals. Facing the choice between the 'closet' and the (eventually impossible) alternative of 'speaking out,' his 'queer subjectivity' experiences a "large collective negation" that leaves him "deeply demoralised" (James 2003c: 361). The negation emphasises society's reliance on denial: as long as Brydon's 'closet' remains unopened, he will remain a respected, albeit haunted (and paranoid) member of society - after all, "he was positively rather liked than not[...,] a dim secondary social success - and all with people who had truly no idea of him" (James 2003c: 352). So long as his 'alter ego' remains hidden within the private sphere of domesticity, the narrative suggests, Brydon will not lose his social status. Speaking out, in this tale's world, would be social suicide. Hence, for Brydon, "the closing [of the door] had practically been an act of mercy" (James 2003c: 361). Socially, the opening of the 'closet' would mean abjection and shame; confronting and naming the 'other' in his self would make Brydon vulnerable: "He knew [...] that should he see the door open, it would too abjectly be the end of him. It would mean that the agent of his shame - for his shame was the deep abjection - was once more at large and in general possession.” (James 2003c: 362) Society's mechanisms of shaming, and its abjection of the (deviant) self are the very processes that enable the modern, sexually charged 'closet.'

James does not, however, end on this note, tacitly accepting social policing through shame. Just before Brydon's final confrontation with his 'alter ego,' James has the house's domestic architecture completely dissolve into a limitless, heterotopian space without boundaries: "The house, withal, seemed immense, the scale of space again inordinate." (James 2003c: 362) The rooms look like "mouths of caverns," and the whole place seems like "some watery under-world [...at] the bottom of the sea" (James 2003c: 362-63). Although Brydon tries to suppress his 'closeted' secret, even delete it from the space of his mind ("They might come in now, the builders, the destroyers - they might come as soon as they would." [James 2003c: 362]), James, in the tale's highly Gothic climax, acknowledges that the house of the mind will not let Brydon forget what he is, what is part of him. The house's "inner door had been thrown far back," and although Brydon knows that "the key was in his pocket," that, in the end, he is the one in control of what remains hidden, and what does not, the house, the architecture of his innermost self, makes him aware of the allure of facing what he is trying to suppress: " $[\mathrm{H}] \mathrm{e}$ let himself go with the sense that here was at last something to meet, to touch, to take, to know." (James 2003c: 363)

When the 'alter ego' finally shows himself, his physicality turns Brydon's vision of the social workings of shame upside-down: covering his face in his hands, “buried as for dark deprecation” (James 2003c: 364), the 'alter ego' confronts Brydon with his 'queer' self ("his queer actuality of evening-dress" [James 2003c: 
364]); "one of these hands had lost two fingers," is symbolically castrated, and when the 'alter ego' finally reveals his face, Brydon can only recoil in horror, "for the bared identity was too hideous as his, and his glare was the passion of his protest” (James 2003c: 364). Brydon's 'closeted alter ego,' effectively unmanned and disfigured, shames Brydon for the very act of denying him, a psychological reaction the latter cannot help but continue: he "look[ed] away from [the face] in dismay and denial” (James 2003c: 364). This face, his own face, is abject to Brydon; he lacks the psychological potential to grasp the meaning of this confrontation. At once part of himself and 'other,' "monstrous[...,] the face of a stranger[...,] evil, odious, blatant, vulgar" (James 2003c: 365), this face, both same and different, "says the things we cannot say" (Zwinger 2008: 13), and physically evokes the taboo that keeps it from speaking its name. James' narrative - very much in the manner of Radcliffe, who makes Emily faint in Udolpho when she draws back the veil - acknowledges the impossibility of Brydon's incorporating his 'closeted' existence. Caught between the desire to 'know' himself, to speak, and the need to deny, to keep hidden, Brydon can only escape by ultimately rejecting to make the choice through a loss off consciousness.

In the end, Brydon remains in denial, but, as discussed above, the plot's heteronormative ending leaves the reader unsatisfied. Although Brydon claims that the experience "had brought him to knowledge, to knowledge" (James 2003c: 366), this knowledge remains unspoken and unlived, heterosocially shared with a woman, but veiled in the language of the 'open secret' that leaves the workings of the paranoid 'closet' intact. To speak - to 'know,' and put into words - is impossible: “"I was to have known myself.' 'You couldn't!'” (James 2003c: 368) Shalyn Claggett, in his analysis of James' tale through the lens of narcissism, convincingly sees the danger that lies at the heart of Brydon's denied self-recognition: "[E]ncountering one's alter ego necessarily traumatizes the subject because it threatens the individual's investment in a single, unified identity. [...] Brydon avoids disaster by choosing ignorance, recognizing in the crucial moment that self-knowledge would be psychically disastrous." (Claggett 2005: 192; 196)

Claggett, however, rejecting a 'reductive' reading of the 'alter ego' as 'homosexual,' overlooks the social dimension of the psychological mechanism he analyses so aptly: Brydon cannot incorporate the narcissistic desire for his rejected self precisely because it is phrased in epistemological terms that are socially regulated. The knowledge Brydon has to deny himself is not just any kind of self-knowledge; it is charged with a taboo, and must not be spoken, but will be spoken about excessively. These are the dynamics of the 'open secret,' of the 'closet,' and while the 'alter ego' remains "a sign in the chain of continuing signification, forever deferring its meaning" (Claggett 2005: 199), this very perpetual deferral emphatically marks the lack of any particular meaning as a significant lack, and makes "The Jolly Cor- 
ner," at the turn of the twentieth century, consciously open to be read not as story about any kind of knowledge, but about the knowledge of 'sexual' deviance. It is no coincidence that Brydon's "obsession for a single meaning [...] comes in contrast with the narrative's openness to alternative possibilities" (Anastasaki 2008: 85). In this very contrast, James demonstrates the circular nature of the paranoid 'closet:' the rhetoric of masculinities that this tale is another example of is in itself paranoid in that it withholds knowledge of what it truly 'is;' this withholding of knowledge, in turn, enables a second dimension of paranoia, that of being read by the paranoid reader as the knowledge that cannot be named. Indeed, this dynamic, as Eric Savoy demonstrates, not only consciously enables 'queer' knowledge, but also de-stabilises a 'gay' subjectivity just as much as it de-stabilises heteronormativity:

"Spencer Brydon returns to America as a self-knowing 'gay' bachelor - closeted, to be sure, but with a sexual affiliation richly and connotatively established - whose provisional identity is contested and unravelled by his encounter with his hypothetical and rather differently closeted double, [and hence] 'The Jolly Corner' might be read as a supple and prescient allegory of the queer undoing of the gay subject." (Savoy 1999: 3)

Although Savoy rightly observes that James disables a reading of Brydon's subjectivity as straightforwardly 'gay,' he does, to an extent, commit to an equally reductive reading of Brydon as 'queer' in the sense of a readable (albeit more complex) 'sexual' identity. I would argue, however, that what the tale produces is not identity at all, but a vision of the impossibility of a stable subjectivity in the 'queer closet' as a rhetorical space of possibility. For Brydon, this space of possibility becomes one of melancholia. He is at once paranoid secret holder and paranoid reader, trying to read himself in an economy of knowledge over which he has lost control. He wants to be able to read himself, pin down what the life he has not lived might have been exactly, and rejects the undefined openness his 'alter ego' suggests. "The mapping of a consciousness which aspired to expand itself in its endless possibilities of being could be overwhelming." (Anastasaki 2008: 88) James simultaneously constructs Brydon's 'queer alter ego' as a locus of endless potential beyond definitions (the 'queer' life postmodernity will aspire to), and exposes this very rejection of definition as unliveable: Although Brydon, in refusing to identify with his 'alter ego,' "rebels against this image of the self and refuses to be pinned down and fixed to that alternative" (Anastasaki 2008: 93), he cannot positively embrace a lack of definite identity either. He both desires and refuses to be named, "queerly suspended between desire for, and repression of, signification" (Savoy 1999: 11), and thus remains trapped in, and actively embraces the paranoid mechanisms of the 'closet.' 
The tale's message remains ambiguous. Eroticised as a desirable state of mind, and, at the same time, perceived as shameful, the paranoid 'closet,' in "The Jolly Corner," is both confirmed and questioned as a valid cultural mechanism. Drained of any association with power (the knowledge has become shared across the lines of gender), only fetishised as a source of ambiguous pleasure, the paranoid 'closet' remains intact. At the same time, however, James constructs a world in which power over knowledge is being democratised, gender relations re-configured, and heteronormativity ultimately made impossible in the face of a 'queerness' that can neither be denied, nor acceptably incorporated any longer. In this moment of masculine 'crisis' - in the word's basic meaning of fundamental change - 'masculinity,' stuck in a 'closet' that is increasingly read, and needs to be spoken as 'homosexual,' repeatedly has to redefine itself along the axes of the more and more rigid dichotomies homosocial/homosexual, and heterosocial/heterosexual. 


\section{Coda}

In the course of this study, I have been tracing the textual construction and production of masculinities, and their complicated relationship to issues of secrecy, space, and sexualities, covering a period of about one hundred and fifty years, years that were crucial for the development of contemporary notions of gendered and sexual definitions. In particular, I have demonstrated how writers of the Gothic and its 'domesticated' subgenres have, from the eighteenth century onwards, characterised masculinities as being closely connected to the paranoid need to protect a secret. This secret, while taking on heavily 'sexualised' connotations only in the course of the nineteenth century, is, from the start, associated with illegitimate private, always potentially non-heteronormative, behaviour.

Horace Walpole's Otranto confronts the reader with a male protagonist whose paranoid need to protect the secret of his illegitimacy and dissociate homosocial power from the threat of homoeroticism makes him a misogynistic tyrant. His 'phallic rage' is not only fatal for the bodies of the women around him, but also ultimately destroys the house of patriarchy itself. Ann Radcliffe takes up this theme in Udolpho, creating the fictional architecture of a Bluebeard's castle which, through its labyrinthine structure, and seemingly impenetrable mystery of locked and unlocked doors, enacts patriarchal terror on the female heroine's mind and body. At the same time, however, Radcliffe questions the ultimate efficacy of such masculine violence, and contrasts Udolpho's failing, masculine spaces with feminine 'alternatives' that provide the novel's (dead and alive) women with the means to have a (secret) room of their own. Finally, William Godwin's Caleb Williams explores the paranoid structure of homosocial masculinities, problematising an obsessive preoccupation with 'honour,' and alluding to the increasingly virulent dilemma of a homoeroticism that gets associated with homosocial secrecy. In eighteenth-century Gothic, then, we already find all the elements of masculine crisis that will continue to preoccupy writers throughout the nineteenth century. With the rise of the middle classes, new forms of privacy, and the emergence of the novel as the genre that explores the workings of the private mind, modern concerns with gendered definitions, increasingly troubled by evolving dichotomies of 'sex- 
ual' definition, found their expression in the fictional architectures of the Gothic. By the mid-nineteenth century, these 'closets' had been 'domesticated' in, among other forms, the writings of the sensation novelists.

In The Woman in White, Wilkie Collins portrays male characters who struggle (and fail) to define for themselves a stable masculine identity. Weak, ill, and effeminate, the men witness epistemological and spatial power shift to the novel's female characters. The men's paranoid attempts to claim narrative authority over the story and its characters' fictional lives foregrounds the genre's preoccupation with secrecy, and its relevance for a politics and rhetoric of gender and sexuality. In No Name, a novel similarly inhabited by male characters of questionable health and virility, Collins further problematises the performative nature of gender roles, and has his actress-heroine subvert the male-homosocial order in liminal spaces which, in themselves, already point towards the unstable ground on which the 'house of patriarchy' is built. Mary Elizabeth Braddon takes these themes a step further. In Lady Audley's Secret, she not only reverses the gendered dynamics of the Bluebeard theme, placing a woman at the centre of spatial and epistemological control, but also suggests a 'way out' of the destructive mechanisms of patriarchal-masculine paranoia, providing her 'queer' male characters with a dream-like, triangulated existence in a fairy-tale ending which, albeit ironically, celebrates deviance as an essential antidote to excessive normativity.

Henry James, around the turn of the twentieth century, skilfully turns this praise of deviance into a 'queer rhetoric' which never quite says what it actually 'means,' but always productively opens up textual spaces that invite the 'paranoid reader' to see 'sexual' meaning where it never becomes explicit. In "The Aspern Papers," James takes up the theme of epistemological power and its spatial organisation having shifted to women. The tale's protagonist, a male editor, not only struggles to penetrate a woman's secret where none might be, but also displays a sentimental attachment to the fetishised letters of a dead poet, the editor's desire for whom forecloses any heternormative solution to the story's gendered conflicts. Similarly, in "In the Cage," James demonstrates the blackmailability of paranoid masculinities in creating a female telegraphist whose position at the centre of communication exchange enables her to put pressure on one of her male clients through a mere rhetoric of knowledge. Explicating knowledge of a secret, as James shows, can be more powerful than actually knowing the secret's content. In "The Jolly Corner," finally, paranoia finds its 'sexual' expression in the protagonist's agonised wish and fear to confront his suppressed 'alter ego,' the unnameable knowledge which - ironically - his female friend seems to have penetrated long ago. The destructive dynamics of paranoid masculinity, and its excessive need to dissociate itself from the threats of both 'queerness' and 'femininity' are only a problem, James appears to suggest, so long as one insists on the need to 'speak one's name.' 
James proposes an alternative: a textual celebration of the ambiguous, the 'sexually' non-explicit, and the open space of possibility.

The dynamics carved out in this book obviously did not disappear after 1900 . The cultural concerns, patterns, and discourses that slowly and heterogeneously emerged in the course of the long nineteenth century have continued to influence cultural production throughout the twentieth and twenty-first centuries. Gendered connotations of fictional architectures, a concern with masculine secrecy, and probably most importantly and explicitly - a diverse involvement with the homosexual 'closet' (staying in, or coming out of it) are only some of the motifs that - despite obvious trans-historical differences - have continued to 'haunt' social and cultural debate over the course of the last century.

In order to illustrate how these topoi are still being negotiated in contemporary, (post-)postmodern English culture, I will have a quick glance at Sam Mendes' 2012 James Bond film Skyfall. Both a relic from the Cold War and its hyper-masculine rhetoric of a defence against the 'Evil Empire,' and, from the start, a never-quite-serious parody of the very machismo Bond has come to represent, the world's most famous secret agent, and his more than half a century old cultural career are a perfect starting point for an analysis of current concerns with gender roles and the importance of secrecy. Bond, after all, works for the British Secret Service, and thus represents one of the organisations that have come to be modern society's abstracted versions of the figure of Count Bluebeard: intelligence agencies are in control of secret knowledge and its circulation, to the exclusion of the majority of the population. I will be using Skyfall as an example to demonstrate how the major nodes around which I have built this book's argument - masculinity, secrecy, sexuality, and space - continue, in their interconnectedness, to form an important set of analytical tools for an understanding of some of our culture's most central concerns.

Masculinity in Skyfall, as embodied by James Bond, is far from unquestionably stable or invulnerable. Physically and psychologically, Daniel Craig's Bond displays a lot more human 'weaknesses' than his 'predecessors.' In particular, Mendes - whose films, such as American Beauty (1999) and Jarhead (2005), often address damaged or in-crisis contemporary masculinities - constructs Bond's masculinity to stand in contrast with what seem to be, up to a point, much stronger female characters. The film begins with Judy Dench's female-Bluebeard-like M ordering Bond to leave behind a dying agent. Shortly afterwards, she commands a young female colleague of theirs (Bluebeard's 'daughter') to risk shooting Bond (which she does) for the sake of getting back a stolen hard drive containing top secret information. The woman who stands at the top of an organisation that controls the circulation of knowledge is willing to sacrifice her 'sons' 'for the greater good.' This performance of 'masculine' ruthlessness, however, comes at a price. A dark 
shadow from her past, former secret agent Raoul Silva, subverts the Secret Service's digital security system, and challenges $M$ to "think of her sins." Although at the centre of power over knowledge, this female Bluebeard's position (and life) begin to be threatened by a suppressed (and supposedly dead) secret from her earlier life - a secret, as we will see, which is very queer indeed.

Bond's own 'male masculinity,' however, is equally in a state of crisis. Although he survives being shot by Eve (whose telling name foregrounds her ambiguous role as both 'mother'/propagator, and seductress/subverter of the patriarchal order), his body remains visibly wounded. When the audience next encounter him on a tropical island, he is still the sexualised subject/object Bond is supposed to be to other women and the audience, but he also seems hurt and depressed, and is constantly drunk. When he returns to active duty, the doctors confirm this impression: Bond's supposedly indestructible male body is simply not fit for service; his hands shake, and there are still bullet splinters in his shoulder. The film skilfully associates Bond's vulnerability with both a deeply ingrained misogyny - albeit always ironised - and a fear of his repressed past. When asked by a psychologist to do word associations, Bond's response to "M" is "bitch;" and to "Skyfall," his childhood home in Scotland, he, at first, does not answer at all, and then simply offers “done." Skyfall, then, constructs Bond's masculinity such that it constantly needs to dissociate itself from 'threats' that might question its status as strong ideal: femininity, psychological depth, and, not least of all, age. Gareth Mallory, who, at the end of the film, becomes the new $\mathrm{M}$, reminds the physically struggling Bond: "It's a young man's game."

True to Bond tradition, the film's inherent glorification of masculine machismo is always mirrored by an already present ironic subversion of this very notion. In Skyfall, the nostalgic inclusion of Bond's old car, the Aston Martin, serves to foreclose any too serious involvement with Bond's gendered struggle. The car, itself a stylish, almost 'camp' reference to the Bond films of the sixties, is the stage of one of the film's most comic encounters between Bond and his 'Bluebeard-mother' M. When Bond, irritated by M's reluctance to simply run off with him in his car, gestures towards the gadgets and technical gear one would expect in a Bond car from its early cultural presence (in particular: a catapult seat), $M$ pokes exasperated fun at the 'camp' masculine extravagance and its associated misogyny the Aston Martin stands for in the Bond universe: "Oh, go on, eject me, see if I care!" The film, and - ironically, 'campily' - its characters are very much aware of this world's gendered anachronisms. Accordingly, when M asks Bond where they are going, he replies: "Back in time."

At the heart of the film's conflicts (gendered and otherwise) lies secrecy. It is the central metaphor that drives plot and characters. As argued above, $M$ is the Bluebeard-like 'female patriarch' who not only tries to protect her nation's 
(house's) secret (a list containing the real names of several secret agents), but also her own forgotten past, the agent she sacrificed, the 'queer son' she rejected, who now comes to have his revenge and open M's (and her nation's) secret chambers. Similarly, Bond needs to go back to his home and face his forgotten past, the childhood he does not want to remember, and the house he grew up in. It is striking that $\mathrm{M}$ and Bond share both an interest in the protection of public secrecy (and the power that comes with the control of such knowledge), and an equally pronounced reluctance to face their own private secrets, fears, and pasts. In a way, both characters are in the 'closet,' in that they hide behind a power derived from secrets that are not theirs, while their own private selves begin to trouble them and question their position - as 'female-patriarchal' Bluebeard, and macho-masculine hero, respectively. Both, I argue, reject a 'queer' side to the story, which comes to chase them in the person of Javier Bardem's Silva, who turns out to be an expert in exposing the nation's, Bond's, and M's secrets.

Skyfall's preoccupation with 'queerness' is staged in an almost Freudian setup, with $\mathrm{M}$ as 'Bluebeard-mother,' who has rejected her 'queer son' (Silva), and now struggles to keep her (supposedly) straight 'other son' from failing both physically and mentally. Silva makes his first appearances as a digital ghost, 'haunting' $\mathrm{M}$ and 'her' Secret Service as a destructive and subversive virus that has her lose control over both knowledge and space. When Bond and the audience first encounter him in person, Silva is the epitome of the perfect gentleman. Suave and polite, his body, manners, and gestures nevertheless register crucial elements that mark Silva as 'other.' Telling a story in which he equates humans with rats he makes disgusting munching sounds, and his blond hair looks artificial and out of place. His slightly effeminate mannerisms make him both uncannily attractive and deviant within the gendered logic of the Bond universe. Silva's first encounter with Bond is striking in many respects. Firstly, he explicitly constructs $M$ as both his and Bond's 'mother,' and, in the space of only a few sentences, disconcertingly touches upon Bond's "unresolved childhood drama," and an alleged rivalry between the two men over the affection of their 'mother.' At the same time, he belittles this 'mother' in a misogynistic move that creates closeness between Bond, who is tied to a chair, and his 'queer alter ego:' "Mummy was very bad." Secondly, the film affords the two men a homoerotic moment that campily hovers between irony and 'the real thing:' when Silva starts to touch Bond and unbutton his shirt ("What's the regulation to cover this?"), Bond, instead of being revolted or disconcerted, seems to enjoy himself, first questioning the situation's strangely triangulated setup ("Are you sure this is about M?"), and then answering Silva's provocative homoerotic advances ("Well, first time for everything.") with the sly remark: "What makes you think this is my first time?" Linguistically eliminating their 'mother' enables the two men to have a moment of unabashed homoeroticism. This misogynistic 
dimension to homosocial/-erotic bonding takes on a cruel actuality when Silva forces Bond to play deadly roulette against him over the body of Severine, one of the film's Bond girls. Silva approaches her with the words: "Darling, your lovers are here," and provocatively tells Bond: "Let's see who ends up on top," before shooing her in the head. In this triangular setup, the mediating female is literally eliminated once she has served the men's purpose.

M's position as 'mother' to Bond and his rejected 'queer' alternate becomes more obvious when she meets Silva in his London prison. M not only displays an obsessive need to distance herself from her own emotions ("Regret is unprofessional."), but also tries to reclaim control over the aberrant 'son' by denying him both an epistemological and a spatial presence: "I will have [your name] struck off [the memorial wall]. Soon, your past will be as non-existent as your future. I'll never see you again." Before escaping from the prison he controls better than his keepers, however, Silva confronts M/Bluebeard/'mother' with the very physical nature of the wound she left when she gave him up to do his duty and kill himself. Showing her his acid-disfigured face, Silva, the 'queer-son-turned-monster,' accuses M: "Look upon your work, mother!"

Silva is not only marked as 'queer' through his bodily performances, but both he and Bond are also associated with liminal spaces that contrast with the centres of power over which M rules: London, the MI6 building, and the political arena. In fact, Skyfall repeatedly shows these latter spaces of patriarchal power to be invaded by Silva's 'ghost:' he not only manages to blow up large parts of the MI6 building by accessing 'mother's' computer, but also attacks a political hearing at which $\mathrm{M}$ has to defend her strategy. Ironically, Bond, in a way, aligns himself with Silva's subversion when he breaks into M's home. Both 'sons' threaten 'mother Bluebeard's' spatial invulnerability. All other spaces in the film are of a strikingly heterotopian nature, in that they are all somehow a bit removed, a bit 'off-centre,' and associated with the past, the nocturnal, or the abandoned: Bond follows an assassin into an empty, high-rise office building, the multiply reflecting and mazelike glass-architecture of which makes it a twenty-first century Gothic space; the Casino in which Bond meets Severine for the second time is a nightmarish place of gambling, complete with man-eating Komodo dragons; Silva's abandoned island city is the epitome of a decaying, ghostly place, dead and alive at the same time; and the London underground tunnels in which Bond tries to hunt down Silva are the 'other city,' the Gothic space which, it turns out, Silva, as opposed to Bond, knows how to access and move in. The most prominent space, however, which returns us to where we started off - the ghostly castle of Otranto - is the Gothic mansion, the liminal domestic: Skyfall, Bond's childhood home in the Scottish moors.

The house has no spatial point of reference. $\mathrm{M}$ and Bond approach it through the misty moors. It seems isolated in this ghostly setting, remote from any other 
physical manifestation of human life. While Bond thus approaches his forgotten past, he, once again, acknowledges M's position as all-knowing 'mother-Bluebeard' when she asks him to talk about his childhood: "You know the whole story." The house itself is a prototypical Gothic mansion in decay, an abandoned ghost house. It is, however, not completely devoid of life: in it, $\mathrm{M}$ and Bond meet Kincade, an old family friend who knew Bond's parents, and who now stands in as Bond's surrogate 'father,' and protector of the house, making this Freudian nuclear family complete. Skyfall, however, is no longer Bond's house: "They sold the place when they heard you were dead." What is more, Kincade explicitly genders the house feminine in answer to M's approving comment: "She is [a beautiful old house]. And like all ladies, she still has her own secretive ways." Bond, it seems, is not only no longer in possession of the house of patriarchy, but it is not the house of patriarchy at all. The 'father' Kincade, it turns out, is this feminine Bluebeard's house's 'male helper' and housekeeper, knowing his way around, and showing M a secret passage that leads out into the moors.

Anticipating the 'queer son's' arrival, Bond, M, and Kincade prepare traps and dynamite in the house, turning it into a weapon. When Silva finally arrives in a helicopter, 'camping up' the scene by playing inappropriately light-hearted music, this moment of irony is heightened by Bond's now actually using the nostalgically charged gadgets in his Aston Martin to fight the 'queer threat' from above. The ensuing showdown begins to reconfigure the 'nuclear family's' structure: $M$ is shot, at first 'heroically' disavowing the seriousness of her wound: "Only my pride is hurt." Shortly afterwards, first the 'parents,' and, after both the Aston Martin and the house (Bond: "I always hated this place.") have been destroyed, the two 'brothers' walk towards the chapel, the patriarchal space in which the 'norm' will be re-established. Directly before his final encounter with M, Silva tells Bond: "Ah well, mother's calling. I'll give her a good-bye kiss for you." Ironically, it is, in the end, not the 'queer son' who kills his 'mother' - in fact, Silva shows a manic kind of love for her, and asks her to kill them both: "Free us both with the same bullet. Only you can do it." Instead, Bond manages to kill his 'queer bother'/'alter ego' first, and $\mathrm{M}$ dies in his arms at the alter, in a 'reversed Pietà:' the 'mother' dies in her crying son's arms, while '(F)father' Kincade is watching over them.

In the end, then, the homosocial-heteronormative system is restored. Both the gender-bending 'Bluebeard-mother,' and her 'queer son' have been sacrificed at the altar of patriarchy. Back in London, the female agent/'femme fatale' Eve becomes re-incorporated into a macho-patriarchal logic, un-becoming the agent, and becoming Moneypenny, secretary and Bond's nostalgic, never-quite-fulfilled heterosexual love-interest - a relationship, though, which has been, from its beginnings in the sixties, 'queer' in that it is clear that it can never actually be consumed. Mallory becomes the new M, making a return to a purely homosocial Secret Ser- 
vice complete. Bluebeard is a man again, the 'house of female patriarchy' (Skyfall) is destroyed, the 'queer son' has died, and Bond's position as macho-masculine hero is - albeit never without irony - confirmed.

Skyfall shows, then, that, in the twenty-first century, a cultural preoccupation with issues of gendered power relations and sexualities has lost nothing of its allure. The Gothic, too, still provides today's storytellers and audiences with a rich imagery of spaces that illustrate and make graspable a psychology of the self that has its roots in the eighteenth century. Considering the history of the cultural processes I have been tracing here, then, what theoretical conclusions can we draw?

Firstly, the gendered dimension of how power over knowledge and space is distributed is a theme that dominates much of eighteenth- and nineteenth-century literature. The question of who keeps what from whom, and who shares what knowledge with whom finds its expression in diverse texts throughout the long nineteenth century.

Secondly, this preoccupation with gender, knowledge, and power is always, albeit never exclusively, linked to issues of 'sexuality.' The rise of Gothic literature coincides historically with the emergence of first modern discourses of sexual identities. As I have demonstrated, homoeroticism (or at least non-heteronormativity) is always already a possibility in the early Gothic, and occupies an increasingly central position in the paranoid plots of nineteenth century fiction. It is worth noting, again, that none of the texts I have been analysing allow for a mere 'gay' reading, not least of all because such a reading would, more often than not, be historically inaccurate. All of these narratives, however, explore masculine paranoia, and the paranoid reader's need to increasingly identify himself and others along the axes homosocial-heterosocial and homosexual-heterosexual as a narrative and plot device that reveals a great deal about the cultural anxieties of the time. It is safe to say that, throughout the long nineteenth century, Gothic literature and its offshoots have produced narratives that represent masculinities in a definitional state of crisis: 'modernity' produced Bluebeards that struggled to dissociate themselves from the threats of both femininity and homoeroticism, desperately gesturing towards a fictional ideal of 'masculinity' that would be safely couched within the boundaries of heteronormativity.

Thirdly, and lastly, many of the stories I have explored here not only expose the paranoid, self-destructive obsessiveness of normative masculinity, but provide narrative spaces for 'queer' alternatives that embrace the possibility of 'otherness,' and strive for a more open, reparative engagement with what constitutes 'knowledge,' and an individual's gendered and 'sexual' (self-)identification.

One of the aims of this book has been to fruitfully bring together research that has been done in gender and queer studies, history, philosophy, and sociology, in order to demonstrate that any attempt to thoroughly understand the ways 
masculinities have been negotiated and defined in literature since the eighteenth century needs to take into account the difficult (and exciting) relationship between genders and 'sexualities.' Homosocial, patriarchal masculinities, in the long nineteenth century, were not only, albeit crucially, structured around misogyny, but also around varying degrees of homophobia. Literary explorations of the homosocial, heterosocial, homoerotic, and heteroerotic dynamics of modern Western patriarchy have, as I have illustrated, been 'queer' before they could be 'gay', but this queerness, far from being a marginal phenomenon, makes up much of the allure of these stories, and accounts for the pleasure of engaging with them as the (no-longer-so-)paranoid reader. 



\section{Works Cited}

\section{Primary Literature}

Braddon, Mary Elizabeth (1998): Lady Audley's Secret, London: Penguin.

Collins, Wilkie (2004): No Name, London: Penguin.

Collins, Wilkie (2003): The Woman in White, London: Penguin.

Godwin, William (2005). Caleb Williams, London: Penguin.

James, Henry (2003a): “The Aspern Papers”, in: Christof Wegelin/Henry B. Wonham (eds.), Tales of Henry James, New York and London: Norton. 53-131.

James, Henry (2003b): "In the Cage", in: Christof Wegelin/Henry B. Wonham (eds.), Tales of Henry James, New York and London: Norton. 229-302.

James, Henry (2003c): “The Jolly Corner”, in: Christof Wegelin/Henry B. Wonham (eds.), Tales of Henry James, New York and London: Norton, 2003. 341-369.

Radcliffe, Ann (2001): The Mysteries of Udolpho, London: Penguin.

SKYFALl (2012) (UK/USA, Dir: Sam Mendes)

Walpole, Horace (2001): The Castle of Otranto, London: Penguin.

\section{Secondary Literature}

Abdulatief, Soraya (1994): "Of Pain or Pleasure: The Construction of Women as Sado-Masochistic Subjects in Radcliffe's The Mysteries of Udolpho", in: Loes Nas/Lesley Marx (eds.), Inter Action, Cape Town: Dept. of Eng., U of Cape Town \& Dept. of Eng., U of Western Cape. 6-14.

Ablow, Rachel (2003): "Good Vibrations: The Sensationalization of Masculinity in The Woman in White", in: Novel: A Forum on Fiction 37, 158-180.

Anastasaki, Elena (2008): "Henry James's Double-Bind: Chasing Possibilities in "The Jolly Corner"”, in: Connotations: A Journal for Critical Debate 18, 82-103. Anderman, Elizabeth (2009): "Hysterical Sensations: Bodies in Action in Wilkie Collins's The Woman in White", in: Marilyn Brock (ed.) From Wollstonecraft 
to Stoker: Essays on Gothic and Victorian Sensation Fiction, Jefferson, NC: McFarland. 79-88.

Anolik, Ruth Bienstock (2007): "Introduction: Sexual Horror: Fears of the Sexual Other”, in: Ruth Bienstock Anolik (ed.) Horrifying Sex: Essays on Sexual Difference in Gothic Literature, Jefferson, NC: McFarland \& Co. 1-24.

Ariès, Philippe (1989): "Introduction", in: Roger Chartier (ed.) Passions of the Renaissance, Cambridge, MA: Belknap P of Harvard UP. 1-11.

Bachman, Maria K. (2010): "Concealing Minds and the Case of The Woman in White", in: Albert D. Pionke/Denise Tischler Millstein (eds.), Victorian Secrecy: Economies of Knowledge and Concealment, Farnham: Ashgate. 75-94.

Barzilai, Shuli (2009): Tales of Bluebeard and His Wives From Late Antiquity to Postmodern Times, New York, NY [et al.]: Routledge.

Bernstein, Stephen (1993): "Reading Blackwater Park: Gothicism, Narrative, and Ideology in The Woman in White", in: Studies in the Novel 25, 291-305.

Bisla, Sundeep (2010): "Over-Doing Things With Words in 1862: Pretense and Plain Truth in Wilkie Collins's No Name", in: Victorian Literature and Culture 38, 1-19.

Bray, Alan (1995): Homosexuality in Renaissance England, New York: Columbia UP.

Bray, Alan (2003): The Friend, Chicago [et al.]: U of Chicago P.

Bredbeck, Gregory W. (1991): Sodomy and Interpretation: Marlowe to Milton, Ithaca and London: Cornell UP.

Brewer, William D. (2000): "Male Rivalry and Friendship in the Novels of William Godwin”, in: Jay Losey/William D. Brewer (eds.), Mapping Male Sexuality: Nineteenth-Century England, Madison, NJ: Fairleigh Dickinson UP. 49-68.

Brown, Ellen (1991): "Revising Henry James: Reading the Spaces of The Aspern Papers", in: American Literature 63, 263-278.

Buelens, Gert (2006): "Imagining Telegraphic Joy in the Canny Cage of Metaphor, Metonymy, and Performativity”, in: The Henry James Review 27, 126-139.

Butler, Judith (2006): Gender Trouble: Feminism and the Subversion of Identity, New York [et al.]: Routledge.

Cannon, Kelly (1994): Henry James and Masculinity: The Man at the Margins, New York: St. Martin's P.

Chartier, Roger (1989a): "Epilogue", in: Roger Chartier (ed.) Passions of the Renaissance, Cambridge, MA: Belknap P of Harvard UP. 609-611.

Chartier, Roger (1989b): "Figures of Modernity: Introduction", in: Roger Chartier (ed.) Passions of the Renaissance, Cambridge, MA: Belknap P of Harvard UP. 15-19.

Chatterjee, Ranita/Horan, Patrick M. (2003): "Teaching the Homosocial in Godwin, Hogg, and Wilde", in: Diane Long Hoeveler/Tamar Heller (eds.), Approaches to 
Teaching Gothic Fiction: The British and American Traditions, New York, NY: Modern Language Association of America. 127-132.

Church, Joseph (1990): "Writing and the Dispossession of Woman in The Aspern

Papers", in: American Imago: Studies in Psychoanalysis and Culture 47, $23-42$.

Claggett, Shalyn (2005): "Narcissism and the Conditions of Self-Knowledge in James's "The Jolly Corner"”, in: The Henry James Review 26, 189-200.

Clery, E. J. (2009): "Walpole, Horace (1717-97)", in: Marie Mulvey-Roberts (ed.)

The Handbook of the Gothic, Basingstoke [et al.]: Palgrave Macmillan. 100103.

Cohen, Ed (1987): "Writing Gone Wilde: Homoerotic Desire in the Closet of Representation", in: PMLA 102, 801-813.

Cohenour, Gretchen (2008): “A Man's Home Is His Castle: Bloodlines and The Castle of Otranto", in: EAPSU Online: A Journal of Critical and Creative Work 5, 73-87.

Collings, David (2003): "The Romance of the Impossible: William Godwin in the Empty Place of Reason", in: ELH 70, 847-874.

Collins, Wilkie (2004): "Preface to the 1862 edition", in: Mark Ford (ed.) No Name, London: Penguin. xxvii-xxviii.

Corber, Robert J. (1990): “Representing the 'Unspeakable': William Godwin and the Politics of Homophobia", in: Journal of the History of Sexuality 1, 85-101.

Daffron, Eric (1995): “'Magnetical Sympathy': Strategies of Power and Resistance in Godwin's Caleb Williams", in: Criticism: A Quarterly for Literature and the Arts 37, 213-232.

David, Deirdre (1998): "Rewriting the Male Plot in Wilkie Collins' No Name", in: Lyn Pykett (ed.) Wilkie Collins, Basingstoke (et al.): Macmillan. 136-148.

Davison, Carol Margaret (2009): Gothic Literature 1764-1824, Cardiff: U of Wales P.

Derrida, Jacques (1989): "How to Avoid Speaking: Denials", in: Sanford Budick/ Wolfgang Iser (eds.), Languages of the Unsayable, New York, NY: Columbia UP. 3-70.

Dever, Carolyn (2006): "The Marriage Plot and Its Alternatives", in: Jenny Bourne Taylor (ed.) The Cambridge Companion to Wilkie Collins, Cambridge: Cambridge UP. 112-124.

Durant, David (1982): “Ann Radcliffe and the Conservative Gothic”, in: SEL: Studies in English Literature, 1500-1900 22, 519-530.

Elam, Diane (1993): "White Narratology: Gender and Reference in Wilkie Collins's The Woman in White", in: Lloyd Davis (ed.) Virginal Sexuality and Textuality in Victorian Literature, Albany: State U of New York P. 49-63.

Ellis, Kate F. (1989): The Contested Castle: Gothic Novels and the Subversion of Domestic Ideology, Urbana, IL: U of Illinois P. 
Erchinger, Philipp (2008): "Secrets Not Revealed: Possible Stories in Wilkie Collins's The Woman in White", in: Connotations: A Journal for Critical Debate 18, 48-81.

Faflak, Joel (2005): “Speaking of Godwin's Caleb Williams: The Talking Cure and the Psychopathology of Enlightenment”, in: English Studies in Canada 31, 99121.

Fincher, Max (2001): "Guessing the Mould: Homosocial Sins and Identity in Horace Walpole's The Castle of Otranto", in: Gothic Studies 3, 229-245.

Foisil, Madeleine (1989): “The Literature of Intimacy”, in: Roger Chartier (ed.) Passions of the Renaissance, Cambridge, MA: Belknap P of Harvard UP. 327361.

Ford, Mark (2004): “Introduction”, in: Mark Ford (ed.) No Name, London: Penguin. vii-xvii.

Foucault, Michel (1994): "Different Spaces”, in: James Faubion (ed.) Aesthetics, Method and Epistemology, Harmondsworth: Penguin. 175-185.

Foucault, Michel (2006): The Will to Knowledge, London: Penguin.

Friedman, Alice T. (1992): “Architecture, Authority, and the Female Gaze: Planning and Representation in the Early Modern Country House", in: Assemblage 18, 40-61.

Friedman, Alice T. (1999): "The Way You Do the Things You Do: Writing the History of Houses and Housing", in: The Journal of the Society of Architectural Historians 58, 406-413.

Fujikawa, Noriko (2008): "Anti-Touristic Sentiment and the Decay of Venice in Henry James's The Aspern Papers and The Wings of the Dove", in: Melanie H. Ross/Greg W. Zacharias (eds.), Tracing Henry James, Newcastle upon Tyne: Cambridge Scholars. 95-109.

Galvan, Jill (2001): "Class Ghosting "In the Cage"”, in: The Henry James Review 22, 297-306.

Garrison, Laurie (2011): Science, Sexuality and Sensation Novels: Pleasures of the Senses, Basingstoke: Palgrave Macmillan.

Gaylin, Ann (2001): "The Madwoman Outside the Attic: Eavesdropping and Narrative Agency in The Woman in White", in: Texas Studies in Literature and Language 43, 303-333.

Gilbert, Pamela K. 1997. Disease, Desire, and the Body in Victorian Women's Popular Novels. Cambridge: Cambridge UP.

Girard, René (1972): Deceit, Desire, and the Novel: Self and Other in Literary Structure, Baltimore: Johns Hopkins UP.

Godwin, William (2005): "Preface to the 1832 'Standard Novels' edition of 'Fleetwood'”, in: Maurice Hindle (ed.) Caleb Williams, London: Penguin. 347-354. 
Gold, Alex, Jr. (1977): “It's Only Love: The Politics of Passion in Godwin's Caleb Williams", in: Texas Studies in Literature and Language: A Journal of the Humanities 19, 135-160.

Goldberg, Jonathan (1992): Sodometries: Renaissance Texts, Modern Sexualities, Stanford, CA: Stanford UP.

Gorilovics, Tivadar (2000): "Secrets of the Forbidden Chamber: Bluebeard", in: Fran Lloyd/Catherine O’Brien (eds.), Secret Spaces, Forbidden Places, New York, NY: Berghahn. 17-28.

Goulemot, Jean Marie (1989): "Literary Practices: Publicizing the Private", in: Roger Chartier (ed.) Passions of the Renaissance, Cambridge, MA: Belknap P of Harvard UP. 363-395.

Graham, Kenneth W. (1990): The Politics of Narrative, New York: AMS PR.

Habermas, Jürgen (1990): Strukturwandel der Öffentlichkeit: Untersuchungen zu einer Kategorie der bürgerlichen Gesellschaft, Frankfurt am Main: Suhrkamp.

Haggerty, George E. (2006): Queer Gothic, Urbana [et al.]: U of Illinois P.

Halberstam, Judith (1998): Female Masculinity, Durham, NC [et al.]: Duke UP.

Halperin, David M. (2002): How to Do the History of Homosexuality, Chicago: U of Chicago P.

Hammond, Paul (2002): Figuring Sex Between Men From Shakespeare to Rochester, Oxford [et al.]: Oxford UP.

Hardy, Barbara (1997): “'The Jolly Corner"”, in: N. H. Reeve (ed.) Henry James: The Shorter Fiction, Reassessments, Basingstoke; New York, NY: Macmillan; St. Martin's. 190-208.

Haynie, Aeron (2000): “"An idle handle that was never turned, and a lazy rope so rotten": The Decay of the Country Estate in Lady Audley's Secret", in: Marlene Tromp/Pamela G. Gilbert/Aeron Haynie (eds.), Beyond Sensation: Mary Elizabeth Braddon in Context, Albany: State U of New York P. 63-74.

Heckmann, Emil. 1930. Blaubart: Ein Beitrag zur vergleichenden Märchenforschung. Dr. phil., Ruprecht-Karls-Universität Heidelberg.

Hedgecock, Jennifer 2008. The Femme Fatale in Victorian Literature: The Danger and the Sexual Threat. Amherst, NY: Cambria P.

Heiland, Donna (2004): Gothic \& Gender: An Introduction, Malden, MA [et al.]: Blackwell.

Heinrichs, Rachel (2007): “Critical Masculinities in Lady Audley's Secret”, in: Victorian Review 33, 103-120.

Hempen, Daniela (1997): "Bluebeard's Female Helper: The Ambiguous Rôle of the Strange Old Woman in the Grimms" "Castle of Murder" and "The Robber Bridegroom",", in: Folklore 108, 45-48.

Hennelly, Mark M., Jr. (1998): "Reading Detection in The Woman in White", in: Lyn Pykett (ed.) Wilkie Collins, New York, NY: St. Martin's. 88-108. 
Heyl, Christoph (2004): A Passion for Privacy: Untersuchungen zur Genese der bürgerlichen Privatsphäre in London, 1660-1800, München: Oldenbourg.

Hingston, Kylee-Anne (2012): “'Skins to Jump Into': The Slipperiness of Identity and the Body in Wilkie Collins's No Name", in: Victorian Literature and Culture 40, 117-135.

Hobsbawm, Eric (1962): The Age of Revolution: 1789-1848, London: Weidenfeld $\&$ Nicolson.

Hobsbawm, Eric (1975): The Age of Capital: 1848-1875, London: Weidenfeld \& Nicolson.

Hobsbawm, Eric (1987): The Age of Empire: 1875-1914, London: Weidenfeld \& Nicolson.

Hoeveler, Diane Long (2008): "Romancing Venice: The Courtship of Percy Shelley in James's The Aspern Papers", in: Melanie H. Ross/Greg W. Zacharias (eds.), Tracing Henry James, Newcastle upon Tyne: Cambridge Scholars. 124-136.

Hogle, Jerrold E. (2002): "Introduction: The Gothic in Western Culture", in: Jerrold E. Hogle (ed.) The Cambridge Companion to Gothic Fiction, Cambridge [et al.]: Cambridge UP. 1-20.

Horner, Avril/Zlosnik, Sue (2012): "Comic Gothic", in: David Punter (ed.) A New Companion to the Gothic, Chichester: Wiley-Blackwell. 321-334.

Horrocks, Ingrid (2007): "More Than a Gravestone: Caleb Williams, Udolpho, and the Politics of the Gothic", in: Studies in the Novel 39, 31-47.

Huebert, Ronald (1997): "Privacy: The Early Social History of a Word", in: The Sewanee Review 105, 210-38.

Huebert, Ronald (2001): “The Gendering of Privacy", in: The Seventeenth Century 16, 37-67.

Hunter, James Paul (1990): Before Novels: The Cultural Contexts of Eighteenth-Century English Fiction, New York [et al.]: Norton.

Jagodzinski, Cecile M. (1999): Privacy and Print: Reading and Writing in Seventeenth-Century England, Charlottesville [et al.]: UP of Virginia.

Jones, Anna (2000): “A Victim in Search of a Torturer: Reading Masochism in Wilkie Collins's No Name”, in: NOVEL: A Forum on Fiction 33, 196-211.

Keane, Angela (2000): Women Writers and the English Nation in the 1790s, Cambridge [et al.]: Cambridge UP.

Keep, Christopher (2011): "Touching at a Distance: Telegraphy, Gender, and Henry James's In the Cage”, in: Colette Colligan/Margaret Linley (eds.), Media, Technology, and Literature in the Nineteenth Century: Image, Sound, Touch, Farnham: Ashgate. 239-255.

King, Emily L. (2008): "Reconsidering Reparation: Mary Elizabeth Braddon's Lady Audley's Secret and Critical Reading Practices”, in: Pacific Coast Philology $43,55-71$. 
Klein, Herbert G. (2008): "Strong Women and Feeble Men: Upsetting Gender Stereotypes in Mary Elizabeth Braddon's Lady Audley's Secret", in: Atenea 28, 161-174.

Kross, Jessica (1999): "Mansions, Men, Women, and the Creation of Multiple Publics in Eighteent-Century British North America", in: Journal of Social History $33,385-408$.

Kucich, John (2006): “Collins and Victorian Masculinity", in: Jenny Bourne Taylor (ed.) The Cambridge Companion to Wilkie Collins, Cambridge: Cambridge UP. 125-138.

Kushnier, Jennifer S. (2002): “Educating Boys to Be Queer: Braddon's Lady Audley's Secret", in: Victorian Literature and Culture 30, 61-75.

Kwolek-Folland, Angel (1995): "Gender as a Category of Analysis in Vernacular Architecture Studies”, in: Perspectives in Vernacular Architecture 5, 3-10.

Langland, Elizabeth (2000): "Enclosure Acts: Framing Women's Bodies in Braddon's Lady Audley's Secret", in: Marlene Tromp/Pamela G. Gilbert/Aeron Haynie (eds.), Beyond Sensation: Mary Elizabeth Braddon in Context, Albany: State U of New York P. 3-16.

Laqueur, Thomas W. (1990): Making Sex: Body and Gender from the Greeks to Freud, Cambridge, MA [et al.]: Harvard UP.

Laughlin, Thomas A. (2010): "The Double Life in the Cage: The Queering of the Social in Henry James's Late Short Fiction”, in: The Henry James Review 31, 154-168.

Ledoux, Ellen Malenas (2011): "Defiant Damsels: Gothic Space and Female Agency in Emmeline, The Mysteries of Udolpho and Secresy", in: Women's Writing 18, 331-347.

Lovell-Smith, Rose (2002): “Anti-Housewives and Ogres' Housekeepers: The Roles of Bluebeard's Female Helper”, in: Folklore 113, 197-214.

MacNeill, Shaun (1998): "A Philosophical Definition of Privacy", in: The Dalhousie Review 78, 437-457.

Margulis, Stephen T. (2003): "Privacy as a Social Issue and Behavioral Concept", in: Stephen T. Margulis (ed.) Contemporary Perspectives on Privacy, Malden, MA [et al.]: Blackwell. 243-261.

McKee, Patricia (2008): “"In the Cage": James's London”, in: Donatella Izzo/Carlo Martinez (eds.), Revisionary Interventions into Henry James, Naples: Università degli studi di Napoli '1'Orientale', Dipartimento di Studi Comparati. 25-41.

McKeon, Michael (2005): The Secret History of Domesticity: Public, Private and the Division of Knowledge, Baltimore: Johns Hopkins UP.

Mengham, Rod (1997): "Wall to Wall: Figuring "The Aspern Papers"”, in: N. H. Reeve (ed.) Henry James: The Shorter Fiction, Reassessments, Basingstoke; New York, NY: Macmillan; St. Martin's. 41-59. 
Mezei, Kathy/Briganti, Chiara (2002): "Reading the House: A Literary Perspective", in: Signs 27, 837-846.

Miller, D. A. (1986): “Cage Aux Folles: Sensation and Gender in Wilkie Collins's The Woman in White", in: Representations 14, 107-136.

Minkley, Gary/Legassick, Martin (2000): “'Not Telling': Secrecy, Lies, and History", in: History and Theory 59, 1-10.

Mitchell, Lee Clark (2007): “'Ghostlier Demarcations, Keener Sounds': Scare Quotes in “The Jolly Corner"”, in: The Henry James Review 28, 223-231.

Monro, David H. (1953): Godwin's Moral Philosophy: An Interpretation of William Godwin, London: Oxford UP.

Monteiro, George (2009): “The 'Bordereau' of The Aspern Papers", in: ANQ: A Quarterly Journal of Short Articles, Notes, and Reviews 22, 33-35.

Moody, Andrew J. (1995): "'The Harmless Pleasure of Knowing': Privacy in the Telegraph Office and Henry James's "In the Cage"', in: The Henry James Review 16, 53-65.

Morrissey, Lee (1998): “'To Invent in Art and Folly': Postmodernism and Walpole's Castle of Otranto", in: Bucknell Review: A Scholarly Journal of Letters, Arts and Sciences 41, 86-99.

Nemesvari, Richard (2000): "Robert Audley's Secret: Male Homosocial Desire and 'Going Straight' in Lady Audley's Secret", in: Calvin Thomas (ed.) Straight with a Twist: Queer Theory and the Subject of Heterosexuality, Urbana and Chicago: U of Illinois P. 109-121.

Nemesvari, Richard (2006): "The Mark of the Brotherhood: Homosexual Panic and the Foreign Other in Wilkie Collins's The Woman in White", in: Richard Fantina/Calvin Thomas (eds.), Straight Writ Queer: Non-Normative Expressions of Heterosexuality in Literature, Jefferson, NC: McFarland. 95-108.

Nixon, Nicola (1999): "The Reading Gaol of Henry James's "In the Cage"”, in: ELH 66, 179-201.

Nixon, Nicola (2004): “'Prismatic and Profitable': Commerce and the Corporate Person in James's 'The Jolly Corner'”, in: American Literature: A Journal of Literary History, Criticism, and Bibliography 76, 807-831.

O’Neill, Michael/Sandy, Mark/Wootton, Sarah (2012): "Introduction”, in: Michael O’Neill/Mark Sandy/Sarah Wootton (eds.), Venice and the Cultural Imagination: 'This Strange Dream upon the Water', London and Vermont: Pickering \& Chatto. 1-9.

OED 2007. privacy, n.: Oxford University Press.

Olson, Greta (2009): "Prisons of Stone and Mind: Henry James's The Princess Casamassima and In the Cage", in: Jan Alber/Frank Lauterbach (eds.), Stones of Law, Bricks of Shame: Narrating Imprisonment in the Victorian Age, Toronto, ON: U of Toronto P. 233-255. 
Perrault, Charles (1697): Histoires ou Contes du Temps Passé, avec des Moralités: Contes de ma Mère l'Oye, Paris: Claude Barbin.

Peters, K. J. (1998): “The Rhetoric of Privacy”, in: The Dalhousie Review 78, 345 363.

Pionke, Albert D. (2010): “Introduction: Victorian Secrecy: An Introduction", in: Albert D. Pionke (ed.) Victorian Secrecy: Economies of Knowledge and Concealment, Farnham [et al.]: Ashgate. 1-14.

Pope, Alexander (2006): “An Epistle to a Lady: Of the Character of Women”, in: Pat Rogers (ed.) The Major Works, Oxford: Oxford UP. 350-358.

Pykett, Lyn (2006): "Collins and the Sensation Novel”, in: Jenny Bourne Taylor (ed.) The Cambridge Companion to Wilkie Collins, Cambridge: Cambridge UP. 50-64.

Pykett, Lyn (2011): "The Woman in White and the Secrets of the Sensation Novel", in: Connotations: A Journal for Critical Debate 21, 37-45.

Radcliffe, Ann (1826): “On the Supernatural in Poetry”, in: The New Monthly Magazine $16,145-152$.

Radford, Andrew D. (2009): Victorian Sensation Fiction, Basingstoke [et al.]: Palgrave Macmillan.

Reesman, Jeanne Campbell (2001): “'The Deepest Depths of the Artificial': Attacking Women and Reality in "The Aspern Papers"”, in: Joseph Dewey/Brooke Horvath (eds.), 'The Finer Thread, The Tighter Weave': Essays on the Short Fiction of Henry James, West Lafayette, IN: Purdue UP. 42-68.

Rodden, John (2009): “Godwin's Caleb Williams: 'A Half-Told and Mangled Tale",, in: College Literature 36, 119-146.

Rosenberg, Joseph Elkanah (2008): "Tangible Objects: Grasping "The Aspern Papers"”, in: Melanie H. Ross/Greg W. Zacharias (eds.), Tracing Henry James, Newcastle upon Tyne: Cambridge Scholars. 202-212.

Rowe, John Carlos (2000): "Working at Gender: "In the Cage"”, in: Peggy McCormack (ed.) Questioning the Master: Gender and Sexuality in Henry James's Writing, Newark, DE: U of Delaware P. 86-103.

Rubin, Gayle (1975): “The Traffic in Women: Notes Toward a Political Economy of Sex", in: Rayna Reiter (ed.) Toward an Anthropology of Women, New York: Monthly Review P. 157-210.

Savoy, Eric (1995): “'In the Cage" and the Queer Effects of Gay History”, in: NOVEL: A Forum on Fiction 28, 284-307.

Savoy, Eric (1999): “The Queer Subject of the "Jolly Corner"”, in: The Henry James Review 20, 1-21.

Sedgwick, Eve Kosofsky (1985): Between Men: English Literature and Male Homosocial Desire, New York: Columbia UP. 
Sedgwick, Eve Kosofsky (1990): Epistemology of the Closet, Berkeley [et al.]: U of California P.

Sedgwick, Eve Kosofsky (2003): Touching Feeling: Affect, Pedagogy, Performativity, Durham and London: Duke UP.

Smith, Andrew (2013): Gothic Literature, Edinburgh: Edinburgh UP.

St. Vincent Millay, Edna (2004): “Untitled Bluebeard Sonnet”, in: Maria Tatar (ed.)

Secrets Beyond the Door: The Story of Bluebeard and his Wives, Princeton and Oxford: Princeton UP. 207.

Stevens, Hugh (1998): “Queer Henry in the Cage”, in: Jonathan Freedman (ed.) The Cambridge Companion to Henry James, Cambridge: Cambridge UP. 120-138.

Stewart, Alan (1995): "The Early Modern Closet Discovered”, in: Representations 50, 76-100.

Storch, Rudolf F. (1967): "Metaphors of Private Guilt and Social Rebellion in Godwin's Caleb Williams", in: ELH 34, 188-207.

Szczepaniak, Monika (2005): Männer in Blau: Blaubart-Bilder in der deutschsprachigen Literatur, Köln: Böhlau.

Talairach-Vielmas, Laurence (2005): "Victorian Sensational Shoppers: Representing Transgressive Femininity in Wilkie Collins's No Name", in: Victorian Review 31, 56-78.

Tatar, Maria (2004): Secrets Beyond the Door: The Story of Bluebeard and His Wives, Princeton and Oxford: Princeton UP.

Tatum, Karen E. 2005. Explaining the Depiction of Violence Against Women in Victorian Literature: Applying Julia Kristeva's Theory of Abjection to Dickens, Brontë, and Braddon. Lewiston, NY: Edwin Mellen P.

Taylor, Jenny Bourne (1988): In the Secret Theatre of Home: Wilkie Collins, Sensation Narrative, and Nineteenth-Century Psychology, London (et al.): Routlege.

Taylor, Jenny Bourne (2006): "Introduction”, in: Jenny Bourne Taylor (ed.) The Cambridge Companion to Wilkie Collins, Cambridge: Cambridge UP. 1-6.

Taylor, Jenny Bourne/Crofts, Russell (1998): “Introduction”, in: Jenny Bourne Taylor (ed.) Lady Audley’s Secret, London: Penguin. vii-xli.

Tefft, Stanton K. (1980a): “General Introduction”, in: Stanton K. Tefft (ed.) Secrecy, New York, NY [et al.]: Human Sciences P. 1-17.

Tefft, Stanton K. (1980b): "Secrecy as a Social and Political Process", in: Stanton K. Tefft (ed.) Secrecy, New York, NY [et al.]: Human Sciences P. 319-346.

Tefft, Stanton K. (1980c): “Secrecy, Disclosure and Social Theory”, in: Stanton K. Tefft (ed.) Secrecy, New York, NY [et al.]: Human Sciences P. 35-74.

Thomas, Kate (2012): Postal Pleasures: Sex, Scandal, and Victorian Letters, New York: Oxford UP.

Thoms, Peter (1992): The Windings of the Labyrinth: Quest and Structure in the Major Novels of Wilkie Collins, Athens: Ohio UP. 
Topinka, Robert J. (2010): "Foucault, Borges, Heterotopia: Producing Knowledge in Other Spaces", in: Foucault Studies 9, 54-70.

Tromp, Marlene/Gilbert, Pamela G./Haynie, Aeron (2000): “Introduction”, in: Marlene Tromp/Pamela G. Gilbert/Aeron Haynie (eds.), Beyond Sensation: Mary Elizabeth Braddon in Context, Albany: State U of New York P. xv-xxviii.

Vaux, Molly (2001): "The Telegraphist as Writer in "In the Cage"”, in: Joseph Dewey/Brooke Horvath (eds.), 'The Finer Thread, The Tighter Weave': Essays on the Short Fiction of Henry James, West Lafayette, IN: Purdue UP. 126-138.

Veeder, William (1999): “The Aspern Portrait", in: The Henry James Review 20, 22-42.

Vincent, David (1998): The Culture of Secrecy: Britain, 1832-1998, Oxford: Oxford UP.

Voskuil, Lynn M. (2001): “Acts of Madness: Lady Audley and the Meanings of Victorian Femininity”, in: Feminist Studies 27, 611-639.

Voß, Heinz-Jürgen (2010): Making Sex Revisited, Bielefeld: Transcript.

Walker, Lynne (2002): "Home Making: An Architectural Perspective", in: Signs 27, 823-835.

Walpole, Horace (2001): "Preface to the Second Edition", in: Michael Gamer (ed.) The Castle of Otranto, London: Penguin. 9-13.

Warren, Carol/Laslett, Barbara (1980): "Privacy and Secrecy: A Conceptual Comparison", in: Stanton K. Tefft (ed.) Secrecy, New York, NY [et al.]: Human Sciences P. 25-34.

Watt, Ian (1995): The Rise of the Novel: Studies in Defoe, Richardson and Fielding, London: Hogarth.

White, Luise (2000): “Telling More: Lies, Secrets, and History”, in: Gary Minkley/ Martin Legassick (eds.), 'Not Telling': Secrecy, Lies, and History, Middletown, CT: Wesleyan University. 11-22.

Williams, M. Kellen (1998): "'Traced and Captured by the Men in the Chaise': Pursuing Sexual Difference in Wilkie Collins's The Woman in White", in: Journal of Narrative Technique 28, 91-110.

Woolston, Jennifer M. (2008): "Lady Audley as the Cunning 'Other': An Economic, Sexual, and Criminal Attack on the Victorian Patriarchal Mindset", in: EAPSU Online: A Journal of Critical and Creative Work 5, 156-168.

Zwinger, Lynda Marie (2008): “'Treat Me Your Subject': Henry James's “The Jolly Corner" and I", in: The Henry James Review 29, 1-15. 
